\title{
2. SITE 366: SIERRA LEONE RISE
}

\author{
The Shipboard Scientific Party ${ }^{1,2}$
}

\section{SITE DATA}

Date Occupied: 22 February 1975 (1140Z)

Date Departed: 1 March 1975 (1614Z)

Time on Site: 7 days, 4 hours, 34 minutes

Position:

Holes 336 and $336 \mathrm{~A}$ : $05^{\circ} 40.7^{\prime} \mathrm{N}, 19^{\circ} 51.1^{\prime} \mathrm{W}$

Accepted Water Depth: 2853 corrected meters (echo sounding)

Bottom Felt With Drill Pipe at: 2870 meters, below rig floor

Penetration: 850.5 meters

Number of Holes: 2

Number of Cores:

Hole 336: 55

Hole 336A: 39

Total Length of Cored Section: 850.5 meters

Total Core Recovered: 582 meters

Oldest Sediment Cored:

Age: Maestrichtian

Nature: Limestone

\section{BACKGROUND AND OBJECTIVES}

\section{Background}

The Sierra Leone Rise can be considered the boundary between the eastern basins of the North and South Atlantic. It is a broad elevation, oriented southwest-northeast and centered around $5^{\circ} \mathrm{N}$ (Figures 1 and 2). At the 4000 meter contour the rise is about 600 $\mathrm{km}$ in length and up to $400 \mathrm{~km}$ in width. It is separated from the Guinea Plateau to the northeast by a narrow

'Yves Lancelot, Lamont-Doherty Geological Observatory, Palisades, New York (Co-Chief Scientist); Eugen Seibold, Geologisch-Palaontologisches, Institüt and Museum der Universität Kiel, Kiel, Germany (Co-Chief Scientist); Pavel Cepek, Bundesanstalt fur Bodenforschung, Hannover, Federal Republic of Germany; Walter E. Dean, Syracuse University, Department of Geology, Syracuse, New York; Vladislav Eremeev, Institute of Geological Sciences of the Academy of Sciences, Laboratory of Lithology Formation, Moscow, USSR; James Gardner, Deep Sea Drilling Project, Scripps Institution of Oceanography, La Jolla, California; Lubomir F. Jansa, Atlantic Geoscience Centre, Geological Survey of Canada, Bedford Institute of Oceanography, Dartmouth, Nova Scotia; David Johnson, Woods Hole Oceanographic Institution, Woods Hole, Massachusetts; Valery Krasheninnikov, Geological Institute of the Academy of Sciences of the USSR, Moscow, USSR; Uwe Pflaumann, GeologischPalaontologisches, Institüt und Museum der Universität Kiel, Kiel, Germany; J. Graham Rankin, Northeast Louisiana University, Department of Chemistry, Monroe, Louisiana; Peter Trabant, Texas A\&M University, Department of Oceanography, College Station, Texas.

${ }^{2}$ David Bukry, U.S. Geological Survey, La Jolla, California (Tertiary nannofossils).

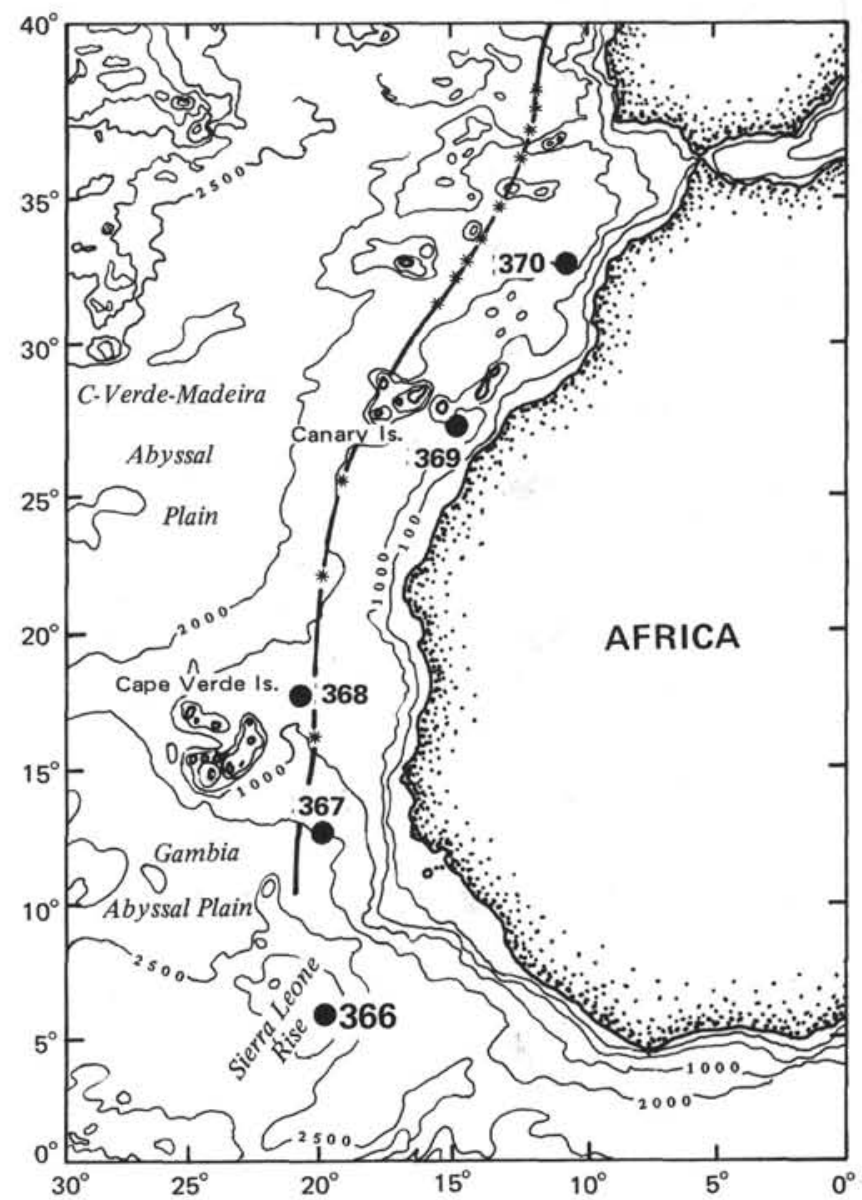

depression, probably the trace of the Guinea Fracture Zone. The Sierra Leone Rise consists of two morphological provinces separated by a broad southwest-northeast depression. Seismic profiles of the rise recorded by Lamont-Doherty Geological Observatory's R/V Vema show that the northwestern province exhibits a rough topography with high and steep basement peaks penetrating the sediment cover. The topography in the southeastern part of the rise is much smoother, and the rise consists of a broad basement swell covered with regularly although moderately stratified sediments forming a southwestnortheast trending plateau with dimensions of about 100 by $150 \mathrm{~km}$ in 2700 to 2900 meters of water (Figure 3 ). A relatively strong reflector observed in the middle part of the sedimentary section can be traced to the deep basin where it appears to be the equivalent of Horizon A defined in the western Atlantic. The maximum thickness of the sedimentary cover observed on the profiles reaches $1.0 \mathrm{sec}$ in the southern part of the plateau and $0.9 \mathrm{sec}$ in the northern part where Site 


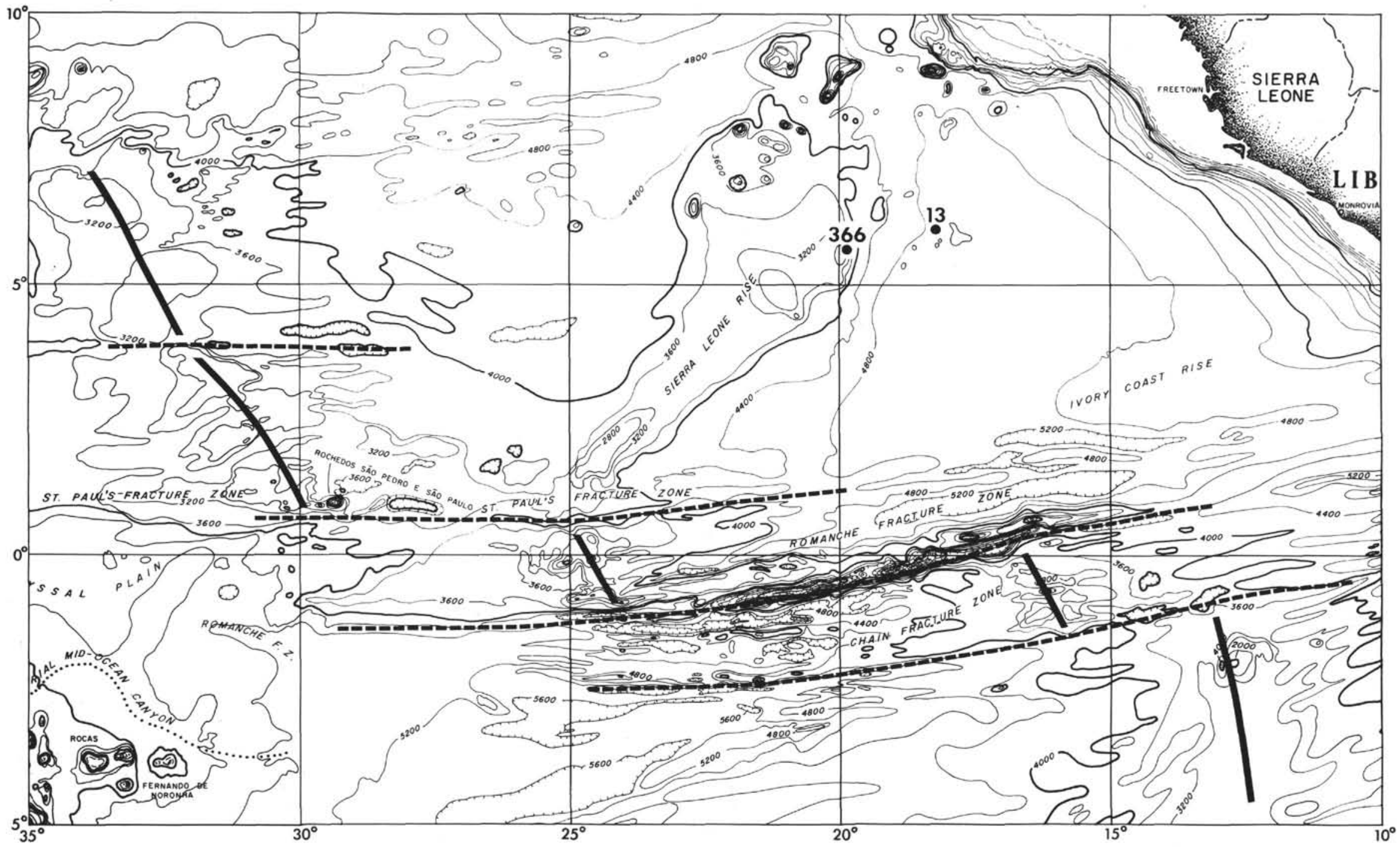

Figure 1. General location of Site 366 with indication of the main structural trends in the vicinity of Sierra Leone Rise. Solid heavy line indicates the ridge axis, dashed lines indicate major fracture zones. Bathymetry from Uchupi (1971). 


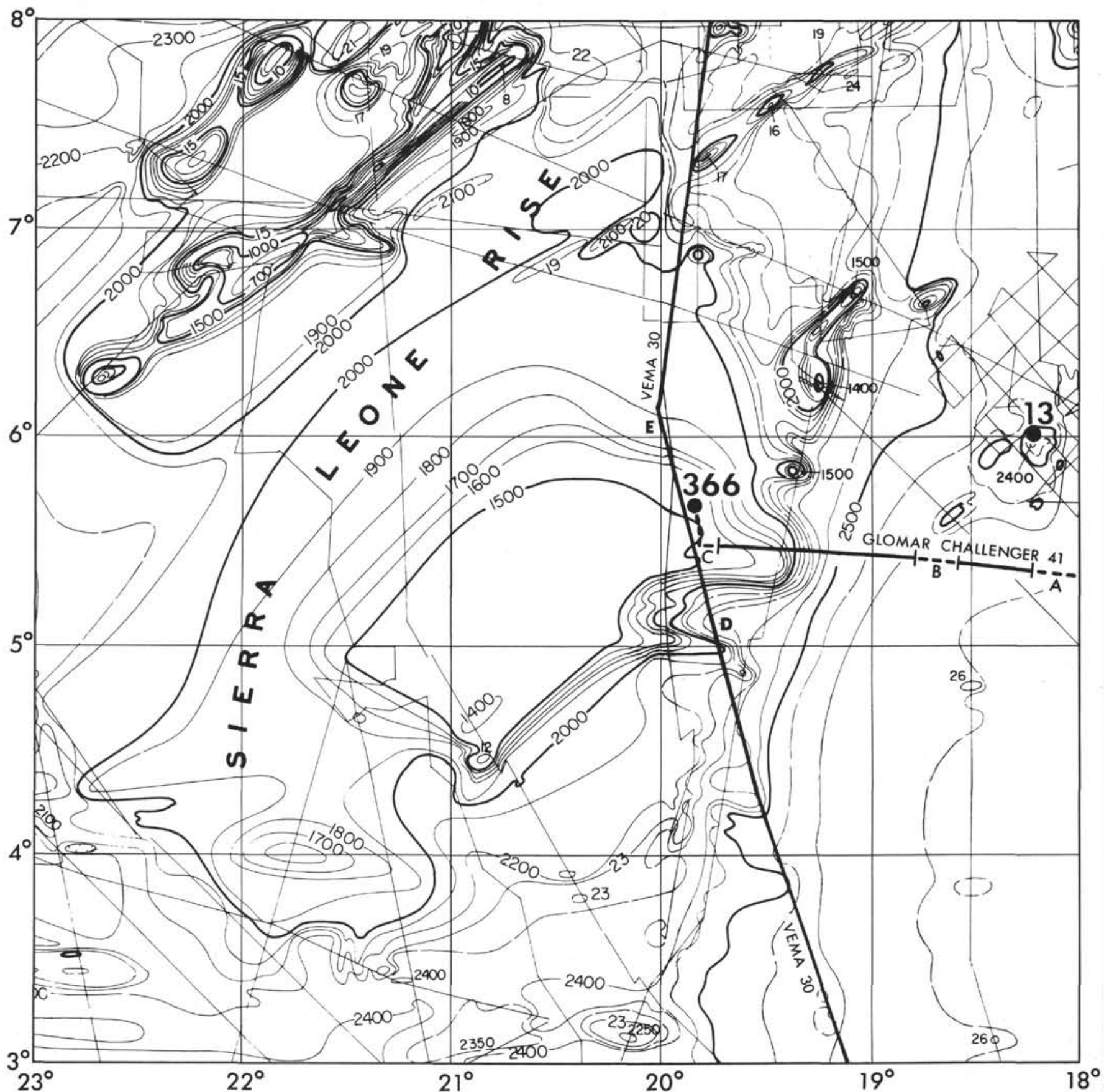

Figure 2. Bathymetry of Sierra Leone Rise in the vicinity of Site 366 (Jacobi and Hayes, in preparation) A, B, and C, on the Glomar Challenger track refer to PDR profiles displayed in Figure 6.

366 is located, although the acoustic basement is not always clearly visible. The nature of the acoustic basement is unknown and, although good continuity with what is believed to be the oceanic basement of the adjacent basins can sometimes be observed in the middle part of the rise, the picture is not as clear in the northern area. In any case, the nature and age of the basement, between the rise and the African margin off Guinea, Sierra Leone, and Liberia, are very poorly known. The age of the oceanic crust on the western side of the rise is also poorly known because of the lack of interpretable magnetic lineations. This results in part from the low latitude of the area.

During Leg 3 of the Deep Sea Drilling Project, Site 13 was drilled on a small satellite rise near the base of the eastern flank of the Sierra Leone Rise in 4588 meters of water (Maxwell et al., 1970). Only part of the scientific objectives of that site could be met because of technical difficulties. The section sampled consists of Tertiary carbonate ooze and clay with radiolarian ooze and chert occurring in the Eocene sediments. The Upper Cretaceous section was sparsely sampled but 


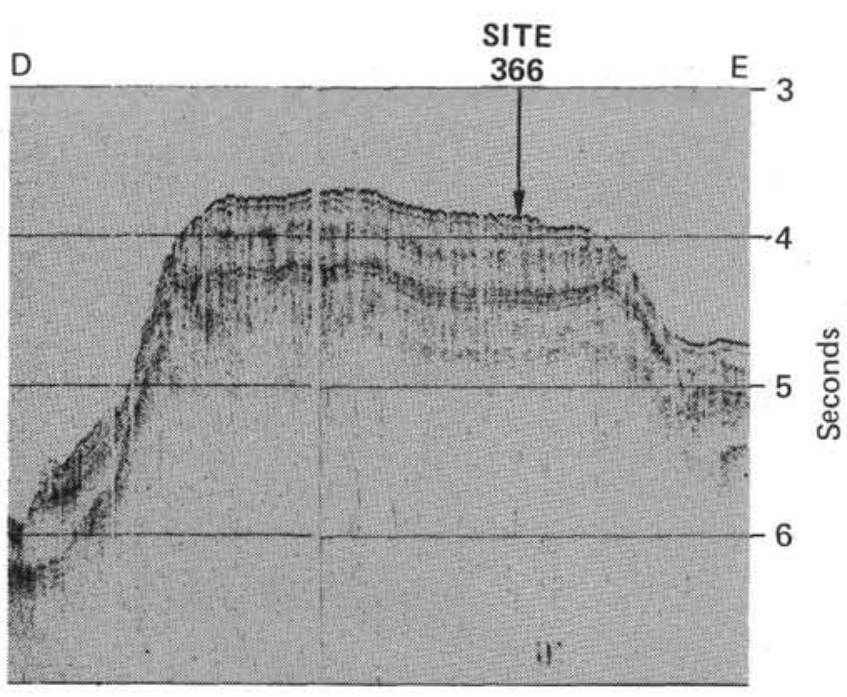

Figure 3. Vema 30 seismic reflection profile recorded on the eastern part of Sierra Leone Rise (see location on Figure 2).

consists of chert, limestone, and shale; the oldest sediments recovered are of Senonian age. Prior to Leg 41 , the Tertiary and Upper Cretaceous history of the rise was still poorly known and the early Cretaceous history totally unknown.

\section{Objectives}

Improvements in the drilling technique and especially the use of new drill bits which are capable of better penetration in hard rock led the JOIDES Atlantic Advisory Panel to consider another attempt at obtaining a better record of the Cenozoic and Mesozoic sediments from Sierra Leone Rise. It was decided to select a site near the top of the rise in order to obtain a more complete and better-preserved carbonate section. Furthermore, the Sierra Leone Rise appears to be one of the few elevated areas of the eastern North Atlantic clearly separated from the margin and hence from any large source of terrigenous material.

The three major objectives assigned to this site were to: (1) obtain a good stratigraphic record for Late Cretaceous and Tertiary; (2) decipher the subsidence history of the rise and its possible role as a barrier capable of restricting the circulation of bottom water between the North and South Atlantic in the past and; (3) eventually determine the nature of the basement, if it could be reached.

\section{Biostratigraphic Record}

Sierra Leone Rise was judged to offer one of the best chances to sample a complete section of the Upper Cretaceous and Tertiary in a low latitude area. The main hiatuses observed on many other rises both in the Atlantic and in other oceans were expected to be either absent or restricted in time because the rise was permanently beneath a relatively high-productivity environment. Therefore, particular attention was to be directed toward sampling critical stratigraphic units in the middle Miocene, the Oligocene, lower Eocene to lower Paleocene, and the Cretaceous/Tertiary boundary sections, all times of observed hiatuses on other rises and in the basins.

\section{Paleocirculation and Subsidence}

The major hiatuses mentioned above are probably directly related to paleocirculation. The Paleocene to middle Eocene hiatus appears to be of worldwide significance because it has been observed in various parts of the Atlantic and Pacific oceans. A late Eocene to Oligocene hiatus has been consistently observed in the North and South Atlantic and appears to be correlated with a major acoustic reflector on the North African margin. This reflector extends from Rockall Bank and Bay of Biscay (Leg 12) to the African margin (Leg 14) and south in the eastern and western South Atlantic basins (Legs 39 and 40). A middle Miocene hiatus was also found during Leg 39 in the southwestern Atlantic. It is not clear if some of these Tertiary hiatuses can be directly related to erosion or nondeposition caused by the initiation of vigorous circulation of Antarctic Bottom Water, or if they result from a sudden increase in the dissolution of carbonates, or possibly from a combination of these two factors. The occurrence of such hiatuses on Sierra Leone Rise would help to confirm their oceanwide significance. This site was also judged to offer a good opportunity to study dissolution facies during the critical periods indicated above because of the anticipated purely pelagic (undiluted) calcareous section. In addition, the possible occurrence of shallow-water carbonate sediments near the base of the section should help document the subsidence history of the Sierra Leone Rise.

\section{Nature of the Basement}

The seismic reflection profile recorded at the proposed site (Figure 3) does not provide a good picture of the acoustic basement and the nature of this lowermost reflector is problematical. Although geometric reconstructions of the Atlantic Ocean for the Early Cretaceous suggest that Sierra Leone Rise lies on oceanic crust, the origin of such an elevation remains unclear and it was hoped that by sampling basement rocks new information could be obtained relative to the nature of the underlying crust and the mode of formation of the rise.

\section{STRATEGY}

Because the re-entry device was not available for Leg 41, we decided to use the alternate strategy recommended and successfully used by Schlanger, Jackson, et al. (1976) during Leg 33. This strategy consists of washing down with very limited coring in the upper part of the section until hard layers are encountered, and continuous coring until the maximum penetration permissible with one drill bit. Then, if it is judged that a new bit is necessary for continuously coring the previously by-passed upper section, the drill string is retrieved and lowered again. Another option is to pull the string out of the hole and punch core continuously the upper soft sediment with the damaged 
bit used for the first run. This strategy presents the advantage of minimizing the rotation time of the bit before it reaches the harder layers. It also considerably reduces the total time spent within the hole and therefore reduces chances of having the hole collapse before the deep objectives can be reached.

\section{OPERATIONS}

The site was approached from the south (Figure 4) on a course parallel to that of the reference profile Vema 30 from Lamont-Doherty Geological Observatory. The Lamont track was nearly intercepted on a $274^{\circ}$ course at $0936 \mathrm{hr}$ (local time) on 22 February 1975. The ship then steamed north for about 35 minutes and altered course to $340^{\circ}$ for the final approach to the site. The seismic record obtained onboard (Figure 5) compared relatively well with the Lamont Vema 30 reference profile so it was decided to reduce speed and drop the beacon underway whenever a suitable location could be observed.

Ideally, the site should be located in a syncline and as far away as possible from the northern slope. Such a location was reached at $5^{\circ} 41^{\prime} \mathrm{N}$ and $19^{\circ} 51^{\prime} \mathrm{W}$. The seismic reflection profile shows a series of parallel reflectors comparable to those observed on the Lamont profile.

A pre-soaked beacon was dropped at $1040 \mathrm{hr}$ (local time) and several minutes later, after observing that the sediment section appeared undisturbed and complete on the profile, the seismic gear was retrieved and the ship reversed course to "lock on" over the beacon. The PDR water depth read 2847 meters corrected.

Running in drill pipe commenced immediately and the bottom was felt by the driller at $1948 \mathrm{hr}$ (local time) when the total length of pipe below the rig floor reached 2870 meters. The drill pipe water depth of 2860 meters was accepted as the Site 366 water depth.

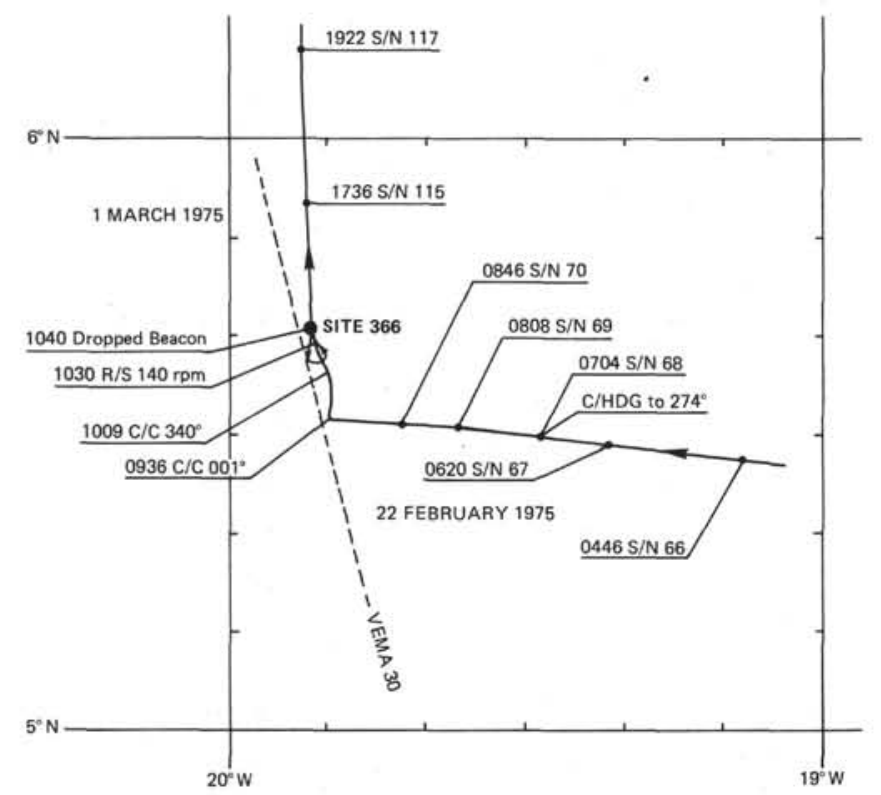

Figure 4. Track of Glomar Challenger approaching and leaving Site 366. Dotted line is track of Vema 30 used as a reference profile for selection of the site.
The first core was punched without rotation or circulation for five meters. Another core, immediately below the first one, was obtained in the same manner. Then the intermittent coring of the upper section began, down to 366 meters. Below that level, coring was continuous (Table 1). Recovery was generally good to excellent in chalk except in the most cherty part of the section. The rate of penetration varied with minor changes in the lithology and ranged from about 25 minutes to over $1 \mathrm{hr}$ per core, depending mainly on the chert content. After a succession of long marly limestone cores, characterized by a very good recovery (Table 1), Core 52 recovered only a small, tapered corecatcher sample. Core 53 yielded the same result. Because the water pressure gauge indicated an anomalously high reading while pumping the core barrel down, it was felt that the bit might be plugged and the center bit was dropped in order to clear it. Another attempt at coring (Core 54) was unsuccessful and the operation was repeated with mud pumped down at high pressure. The core barrel was dropped for Core 55 and again retrieved empty. The continuing high water pressure indication suggested that the bit was still plugged and it was decided to pull out of the hole, terminating Hole 366 at a total depth of 850.5 meters sub-bottom.

The drill string was retrieved and the bit was on deck at $1130 \mathrm{hr}$ (local time) on 27 February. It was found plugged by tightly packed sediment, as predicted. The sediment plug was thick enough so as to prevent correct seating and latching of the core barrel. Otherwise the drill bit was in good condition except for slightly sticky cones and some missing inserts. The Teflon rings of the bit seal were broken, although none of them blocked the entrance of the core barrel. The rings were replaced before the bit was put back in place. It was decided to use the same bit to continuously core the relatively soft upper part of the section down to 366 meters subbottom. Drill pipe was run down for drilling Hole 366A and the sea floor was reached at $2041 \mathrm{hr}$ (local time) when the total length of the drill string recorded 2869 meters below the rig floor.

Coring was continuous with a relatively good recovery except in some of the soft chalk layers. Neither broken circulation nor minor pumping seemed to prove very effective in solving that problem. Coring was terminated after Core $39 \mathrm{~A}$ had been cut at $0918 \mathrm{hr}$ on 1 March. At that time, the total penetration in Hole 366A was 367 meters sub-bottom, 1 meter deeper than the depth at which continuous coring started in Hole 366. The drill string was recovered and the ship was underway on 2 March at $1514 \mathrm{hr}$. The post-site survey consisted of a run at 5 knots over the beacon on the same course as the final approach (see profile on Figure 5 ). Cruise speed was resumed shortly thereafter and the course was set toward Site 367.

A sonobuoy record was attempted on site, using various frequency settings, but because the buoy had to be tethered, neither wide-angle reflections nor refractions were expected. The sonobuoy record was terminated when the ship began backing over the airguns. Weather conditions were excellent during the entire week spent on site and this probably accounts in 


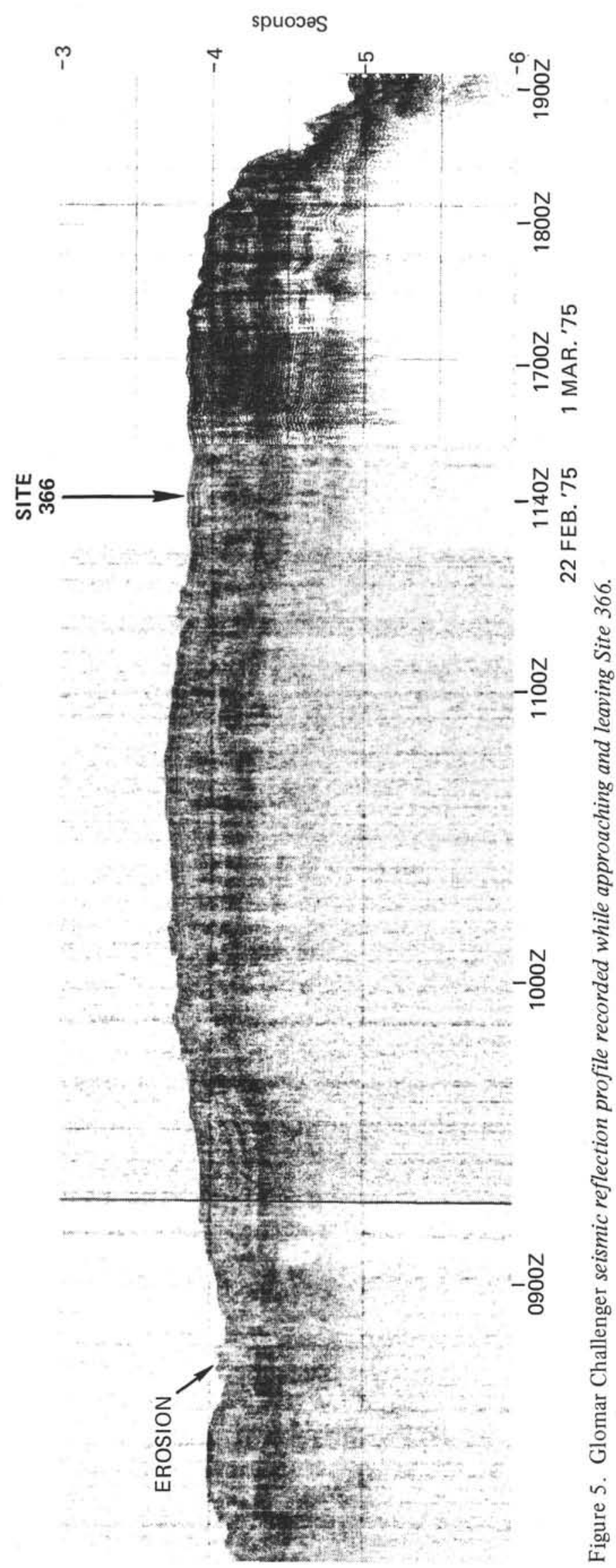

part for the good record of the drill bit prior to its plugging.

\section{UNDERWAY OBSERVATIONS}

The PDR profiles (Figure 6) recorded along the approach courses exhibit some interesting features. The record obtained in the Sierra Leone Basin abyssal plain (Figure 6a) shows a smooth sea floor and several (up to four) subbottom reflectors. Such penetration with a 12$\mathrm{kHz}$ PDR can be related to the possible occurrence of very fine-grained and soft sediments at the sea floor, which suggests a low-energy environment with minimal bottom-water circulation in recent times. While approaching the base of Sierra Leone Rise, the character of the PDR record changed and the occurrence of small depressions at the base of basement peaks (Figure 6b) is indicative of some bottom-current circulation. Finally the upper part of the rise (Figure 6c) exhibits a relatively rough microtopography suggesting some erosion by bottom currents. The seismic reflection profile recorded while approaching the site (Figure 3 ) shows particularly good evidence of such erosion where a channel is cutting relatively deep within the upper part of the sedimentary section.

\section{LITHOLOGY .}

\section{Introduction}

The sediments of Site 366 are predominantly a pelagic carbonate facies. We subdivided the section into four units, based on composition and color. Table 2 summarizes the lithologic sequence.

\section{Lithologic Descriptions}

\section{Unit 1-Nannofossil Marl and Ooze (Cores 1A through 15A, Section 4)}

This unit is composed of nannofossil marl and ooze with varying abundances of foraminifers, radiolarians, and diatoms. The first seven cores sampled nannofossil ooze and marl of moderate yellowish brown (10YR5/4) to dark yellowish brown $(10 \mathrm{YR} 5 / 8)$ color with $\mathrm{CaCO}_{3}$ contents ranging from $47 \%$ to $88 \%$. The next eight cores are classified as nannofossil oozes on the basis of higher $\mathrm{CaCO}_{3}$ content (64\% to $86 \%$ ). They are very light gray (N8) to light olive-gray (5Y6/1). The whole unit is mottled, and in places contains very thin $(5$ to $15 \mathrm{~cm})$ clay interbeds. This unit contains rare to common $(1 \%$ to $25 \%$ ) foraminifers, rare radiolarians (only in the Pleistocene section), diatoms, black ferromanganese (?) flecks, and fish debris. Cores 1 and 2 contain both marine and fresh-water diatoms and opal phytoliths.

Intense drilling disturbance in this unit precludes any further detailed description of sedimentary structures, contacts, or interbeds.

\section{Unit 2-Cyclic Alternations of Nannofossil Ooze or Nannofossil Chalk and Nannofossil Marl or Pelagic Clay \\ (Cores 15A, Section 5 [Hole 366A], through Core 16} [Hole 366])

This unit consists of cyclic alternations of nannofossil ooze and nannofossil marl $\left(\mathrm{CaCO}_{3}\right.$ ranges from 
TABLE 1

Coring Summary, Site 366

\begin{tabular}{ccccccc}
\hline & Date & Depth From & Depth Below \\
Drill Floor & Sea Floor \\
$(\mathrm{m})$ & Time & $\begin{array}{c}\text { Cored } \\
(\mathrm{m})\end{array}$ & $\begin{array}{c}\text { Recovered } \\
(\mathrm{m})\end{array}$ & $\begin{array}{c}\text { Recovery } \\
(\%)\end{array}$ \\
\hline
\end{tabular}

\section{Hole 366}

$\begin{array}{llll}1 & 22 & 2029 & 2870.0-2875.0\end{array}$

$\begin{array}{llll}2 & 22 & 2138 & 2875.0-2884.5 \\ 3 & 22 & 2345 & 2989.0-2998.5 \\ 4 & 23 & 0255 & 3112.5-3122.0\end{array}$

$\begin{array}{llll}3 & 22 & 2345 & 2989.0-2998.5 \\ 4 & 23 & 0255 & 3112.5-3122.0\end{array}$

$5 \quad 23 \quad 0600 \quad 3236.0-3245.5$

$\begin{array}{llll}6 & 23 & 0709 & 3245.5-3255.0\end{array}$

$\begin{array}{llll}7 & 23 & 0815 & 3255.0-3264.5\end{array}$

$\begin{array}{llll}8 & 23 & 0930 & 3264.5-3274.0 \\ 9 & 23 & 1050 & 3274.0-3283.5\end{array}$

$10 \quad 23 \quad 1158 \quad 3283.5-3293.0$

$\begin{array}{llll}11 & 23 & 1327 & 3293.0-3302.5\end{array}$

$12 \quad 23 \quad 1451 \quad 3302.5-3312.0$

$13 \quad 23 \quad 1612 \quad 3312.0-3321.5$

$\begin{array}{llll}14 & 23 & 1725 & 3321.5-3331.0\end{array}$

$\begin{array}{llll}15 & 23 & 1847 & 3331.0-3340.5\end{array}$

$\begin{array}{llll}16 & 23 & 2011 & 3340.5-3350.0\end{array}$

$17 \quad 23 \quad 2205 \quad 3350.0-3359.5$

$\begin{array}{llll}18 & 24 & 0023 & 3359.5-3369.0\end{array}$

$19 \quad 24 \quad 0202 \quad 3369.0-3378.5$

$\begin{array}{llll}20 & 24 & 0415 & 3378.5-3388.0\end{array}$

$\begin{array}{llll}21 & 24 & 0635 & 3388.0-3397.5\end{array}$

22

23

24

25

26
27

27

28
29

29

30

31
32

33

3

35

37

38

39
40

41

41
42
43

$43 \quad 25$

$44 \quad 26$

$45 \quad 26$

$46 \quad 26$

$47 \quad 26$

$48 \quad 26$

$\begin{array}{ll}49 & 26 \\ 50 & 26\end{array}$

$\begin{array}{ll}51 & 26\end{array}$

$52 \quad 26$

$\begin{array}{ll}53 & 26 \\ 54 & 27\end{array}$

$\begin{array}{ll}55 & 27\end{array}$

Hole 366A

$\begin{array}{ll}1 & 27 \\ 2 & 27 \\ 3 & 27 \\ 4 & 28 \\ 5 & 28 \\ 6 & 28\end{array}$

$0.0-5.0$
$5.0-14.5$
$119.0-128.5$
$242.5-252.0$
$366.0-375.5$
$375.5-385.0$
$385.0-394.5$
$394.5-404.0$
$404.0-413.5$
$413.5-423.0$
$423.0-432.5$
$432.5-442.0$
$442.0-451.5$
$451.5-461.0$
$461.0-470.5$

$470.5-480.0$

480.0-489.5

489.5-499.0

499.0-508.5

508.5-518.0

518.0-527.5

527.5-537.0

537.0-546.5

546.5-556.0

556.0-565.5

565.5-575.0

575. 0-584.5

584.5-594.0

594.0-603.5

603.5-613.0

613.0-622.5

622.5-632.0

632.0-641.5

641.5-651.0

651.0-660.5

660.5-670.0

670.0-679.5

679.5-689.0

689.0-698.5

698.5-708.0

708.0-717.5

717.5-727.0

727.0-736.5

736.5-746.0

755.5-765.0

765.0-774.5

$774.5-784.0$

784.0-793.5

793.5-803.0

803.0-812.5

812.5-822.0

822.0-831.5

831.5-841.0

841.0-850.5
746.0-755.5

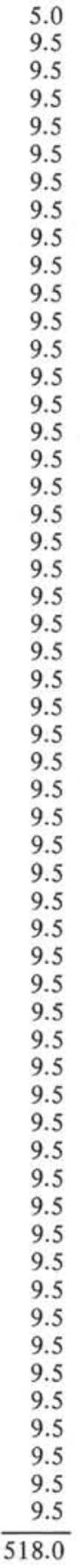

$5.2 \quad 100$

$7.7 \quad 8$

9.4

3.8

$9.5 \quad 100$

$8.1 \quad 85$

6.7571

$4.85 \quad 51$

$5.95 \quad 63$

$9.1 \quad 96$

$1.65 \quad 17$

$5.8 \quad 61$

$3.4 \quad 36$

6.973

$3.1 \quad 33$

$3.2 \quad 34$

$0.5 \quad 5$

0.55

$1.1 \quad 12$

$1.8 \quad 19$

$3.5 \quad 37$

$3.2 \quad 34$

$3.1 \quad 33$

$4.9 \quad 52$

$1.8 \quad 19$

$3.2 \quad 34$

$\begin{array}{ll}7.5 & 79\end{array}$

$6.5 \quad 68$

$6.0 \quad 63$

$0.6 \quad 6$

$5.6 \quad 59$

$7.0 \quad 74$

$6.4 \quad 67$

$6.7 \quad 71$

$7.8 \quad 82$

$7.1 \quad 75$

$8.8 \quad 93$

$8.3 \quad 87$

$8.1 \quad 85$

$8.8 \quad 93$

$8.2 \quad 86$

$9.5 \quad 100$

9.5100

$7.5 \quad 79$

$8.5 \quad 90$

$3.6 \quad 38$

$9.5+\quad 100+$

$9.5+\quad 100+$

$8.7 \quad 92$

$6.4 \quad 67$

$9.5+\quad 100+$

$0.2 \quad 2$

0.2

0.0

$\frac{0.0}{304.0}$

$\begin{array}{r}2 \\ 0 \\ 0 \\ \hline 59\end{array}$

\begin{tabular}{rrrr}
$0.0-6.0$ & 6.0 & 6.0 & 100 \\
$6.0-15.5$ & 9.5 & 9.5 & 100 \\
$15.5-25.0$ & 9.5 & 8.6 & 91 \\
$25.0-34.5$ & 9.5 & 9.2 & 97 \\
$34.5-44.0$ & 9.5 & 9.3 & 98 \\
$44.0-53.5$ & 9.5 & 8.6 & 91 \\
\hline
\end{tabular}


TABLE 1 - Continued

\begin{tabular}{|c|c|c|c|c|c|c|c|}
\hline Core & $\begin{array}{c}\text { Date } \\
\text { (Feb. 19.75) }\end{array}$ & Time & $\begin{array}{l}\text { Depth From } \\
\text { Drill Floor } \\
\text { (m) }\end{array}$ & $\begin{array}{l}\text { Depth Below } \\
\text { Sea Floor } \\
\text { (m) }\end{array}$ & $\begin{array}{c}\text { Cored } \\
(\mathrm{m})\end{array}$ & $\begin{array}{l}\text { Recovered } \\
\text { (m) }\end{array}$ & $\begin{array}{c}\text { Recovery } \\
(\%)\end{array}$ \\
\hline \multicolumn{8}{|c|}{ Hole 366A - Continued } \\
\hline 7 & 28 & 0233 & $2922.5-2932.0$ & $53.5-63.0$ & 9.5 & 6.0 & 95 \\
\hline 8 & 28 & 0320 & $2932.0-2941.5$ & $63.0-72.5$ & 9.5 & 8.8 & 93 \\
\hline 9 & 28 & 0415 & $2941.5-2951.0$ & $72.5-82.0$ & 9.5 & 8.4 & 88 \\
\hline 10 & 28 & 0511 & $2951.0-2960.5$ & $82.0-91.5$ & 9.5 & 1.6 & 17 \\
\hline 11 & 28 & 0604 & $2960.5-2970.0$ & $91.5-101.0$ & 9.5 & 8.4 & 88 \\
\hline 12 & 28 & 0656 & $2970.0-2979.5$ & $101.0-110.5$ & 9.5 & 8.8 & 93 \\
\hline 13 & 28 & 0748 & $2979.5-2989.0$ & $110.5-120.0$ & 9.5 & 7.3 & 77 \\
\hline 14 & 28 & 0846 & $2989.0-2998.5$ & $120.0-129.5$ & 9.5 & 9.5 & 100 \\
\hline 15 & 28 & 0935 & $2998.5-3008.0$ & $129.5-139.0$ & 9.5 & 9.5 & 100 \\
\hline 16 & 28 & 1045 & $3008.0-3017.5$ & $139.0-148.5$ & 9.5 & 7.4 & 78 \\
\hline 17 & 28 & 1145 & $3017.5-3027.0$ & $148.5-158.0$ & 9.5 & 9.5 & 100 \\
\hline 18 & 28 & 1237 & $3027.0-3036.5$ & $158.0-167.5$ & 9.5 & 8.6 & 91 \\
\hline 19 & 28 & 1325 & $3036.5-3046.0$ & $167.5-177.0$ & 9.5 & 0.0 & 0 \\
\hline 20 & 28 & 1433 & $3046.0-3055.5$ & $177.0-186.5$ & 9.5 & 3.5 & 37 \\
\hline 21 & $\cdot 28$ & 1545 & $3055.5-3065.0$ & $186.5-196.0$ & 9.5 & 9.5 & 100 \\
\hline 22 & 28 & 1633 & $3065.0-3074.5$ & $196.0-205.5$ & 9.5 & 2.5 & 26 \\
\hline 23 & 28 & 1730 & $3074.5-3084.0$ & $205.5-215.0$ & 9.5 & 9.1 & 96 \\
\hline 24 & 28 & 1818 & $3084.0-3093.5$ & $215.0-224.5$ & 9.5 & 2.4 & 25 \\
\hline 25 & 28 & 1914 & $3 \mathrm{C} 93.5-3103.0$ & $224.5-234.0$ & 9.5 & 1.5 & 16 \\
\hline 26 & 28 & 2009 & $3103.0-3112.5$ & $234.0-243.5$ & 9.5 & 7.2 & 76 \\
\hline 27 & 28 & 2058 & $3112.5-3122.0$ & $243.5-253.0$ & 9.5 & 8.3 & 87 \\
\hline 28 & 28 & 2157 & $3122.0-3131.5$ & $253.0-262.5$ & 9.5 & 9.5 & 100 \\
\hline 29 & 28 & 2251 & $3131.5-3141.0$ & $262.5-272.0$ & 9.5 & 8.6 & 91 \\
\hline \multirow[t]{2}{*}{30} & 28 & 2347 & $3141.0-3150.5$ & $272.0-281.5$ & 9.5 & 9.3 & 98 \\
\hline & March & & & & & & \\
\hline 31 & 1 & 0048 & $3150.5-3160.0$ & $281.5-291.0$ & 9.5 & 6.5 & 68 \\
\hline 32 & 1 & 0225 & $3160.0-3169.5$ & $291.0-300.5$ & 9.5 & 0.2 & 2 \\
\hline 33 & 1 & 0319 & $3169.5-3179.0$ & $300.5-310.0$ & 9.5 & 8.4 & 88 \\
\hline 34 & 1 & 0424 & $3179.0-3188.5$ & $310.0-319.5$ & 9.5 & 8.7 & 92 \\
\hline 35 & 1 & 0523 & $3188.5-3198.0$ & $319.5-329.0$ & 9.5 & 7.9 & 83 \\
\hline 36 & 1 & 0624 & $3198.0-3207.5$ & $329.0-338.5$ & 9.5 & 6.6 & 70 \\
\hline 37 & 1 & 0720 & $3207.5-3217.0$ & $338.5-348.0$ & 9.5 & 8.0 & 84 \\
\hline 38 & 1 & 0820 & $3217.0-3226.5$ & $348.0-357.5$ & 9.5 & 6.2 & 65 \\
\hline 39 & 1 & 0918 & $3226.5-3236.0$ & $357.5-367.0$ & 9.5 & 6.1 & 64 \\
\hline Total & & & & & 367.0 & 278.0 & 76 \\
\hline
\end{tabular}

$41 \%$ to $90 \%$ ) which grade into cycles of nannofossil chalk $\left(60 \%\right.$ to $\left.90 \% \mathrm{CaCO}_{3}\right)$ and pelagic clay in Cores $23 \mathrm{~A}$ through 16 . The nannofossil ooze and nannofossil chalk are typically light greenish-gray $(5 \mathrm{GY} 8 / 1)$. The ooze becomes semilithified at 366 meters and thus is classified as chalk. The $\mathrm{CaCO}_{3}$ content of these sediments varies from $65 \%$ to $90 \%$. Burrows are common in this facies (see Harrington, this volume), especially Chondrites and Zoophycos, and some $\mathrm{Hel}$ minthoida. Clay, foraminifers, radiolarians, fish debris, and ferromanganese(?) flecks and liesegang halos are rare to common and appear throughout these sediments. The halos are especially common around burrows (Figure 7).

The nannofossil marl and pelagic clay are yellowish brown (10YR5/4; marl) to dark greenish gray (5G6/1; pelagic clay). They are both burrowed with Zoophycos and Chondrites and some sections show thin parallel, horizontal laminations. Smear-slide analyses show rare to common nannofossils, radiolarians, sponge spicules, fish debris, and common diatoms. The varying abundance of nannofossils and lack of foraminifers distinguish this facies from the nannofossil ooze and chalk.
Each cycle of Unit 2 is characterized by a nannofossil ooze overlying a nannofossil marl, or chalk over pelagic clay. The cycles vary from $10 \mathrm{~cm}$ to over $50 \mathrm{~cm}$ in thickness, and the more calcareous facies is always the thicker of the two components. Within each cycle the contact between the lower marl and the upper ooze is gradational, but the boundary separating individual cycles is generally sharp. See Dean et al., this volume, for more detailed description of these cycles.

\section{Unit 3-Cyclic Alternations of Nannofossil Chalk and Porcellanite or Chert, and Siliceous Limestone (Cores 17 through 37)}

Cyclic alternations of nannofossil chalk and siliceous limestone, porcellanite, and minor chert nodules characterize Unit 3. The nannofossil chalk is similar in most respects to that of Unit 2. They are light greenish gray $(5 G Y 8 / 1)$, semilithified, burrowed with Zoophycos, Chondrites, and some halo-rimmed burrows, and are laminated in some sections. The chalks have rare foraminifers and radiolarians and common euhedral and subhedral calcite. This facies grades into a siliceous limestone with depth, the 
A

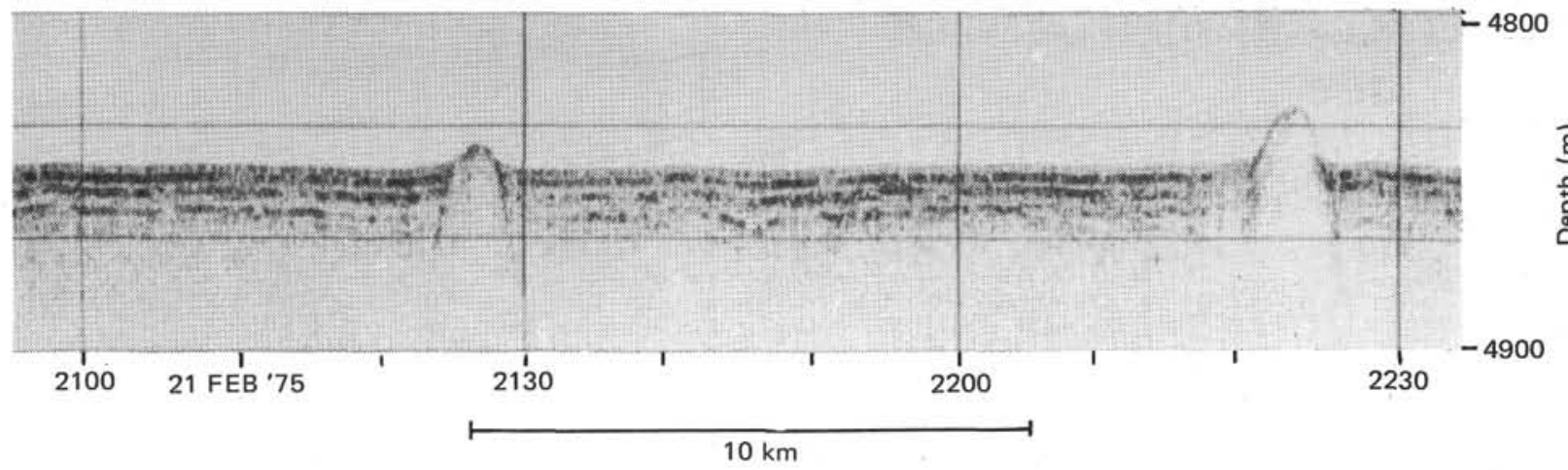

$\bar{\xi}$
口े
口̆

B

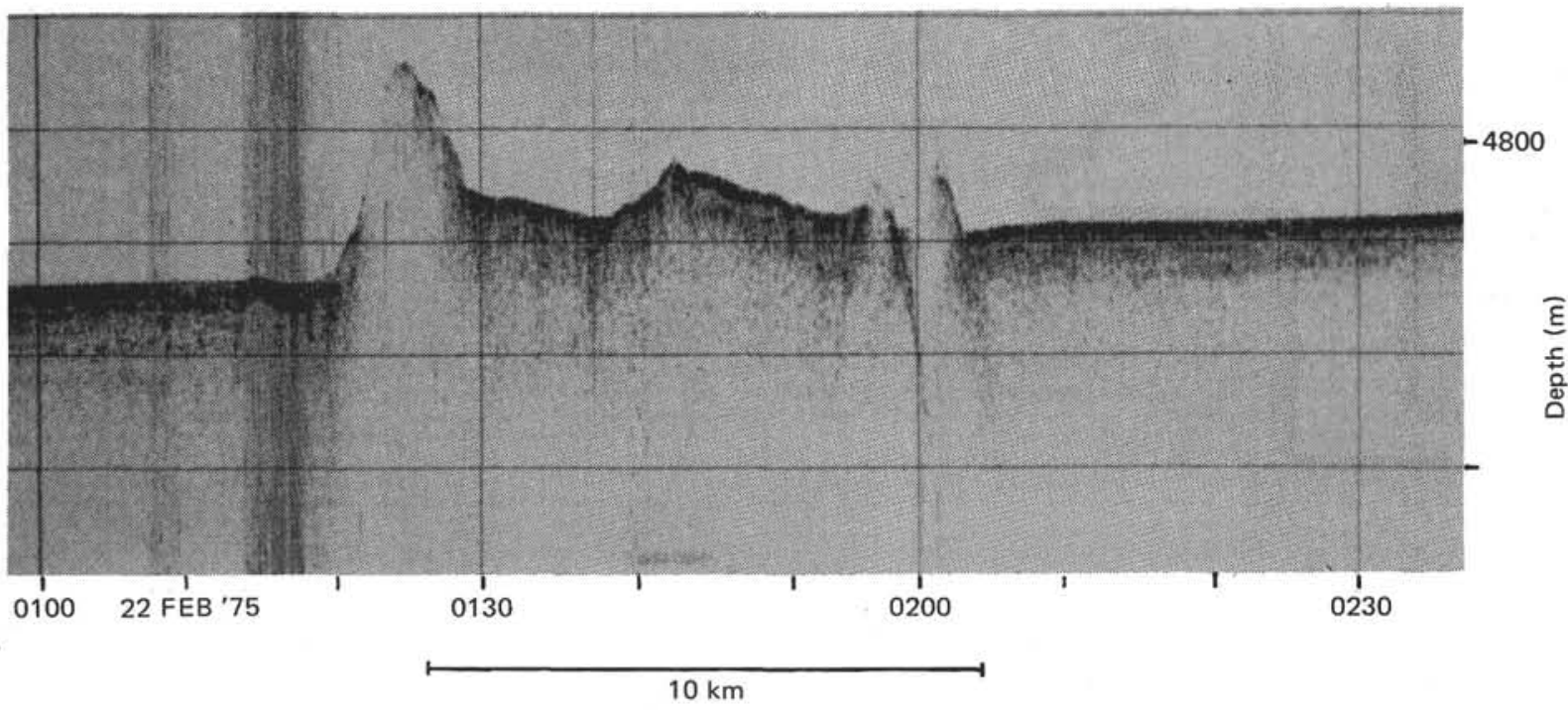

C

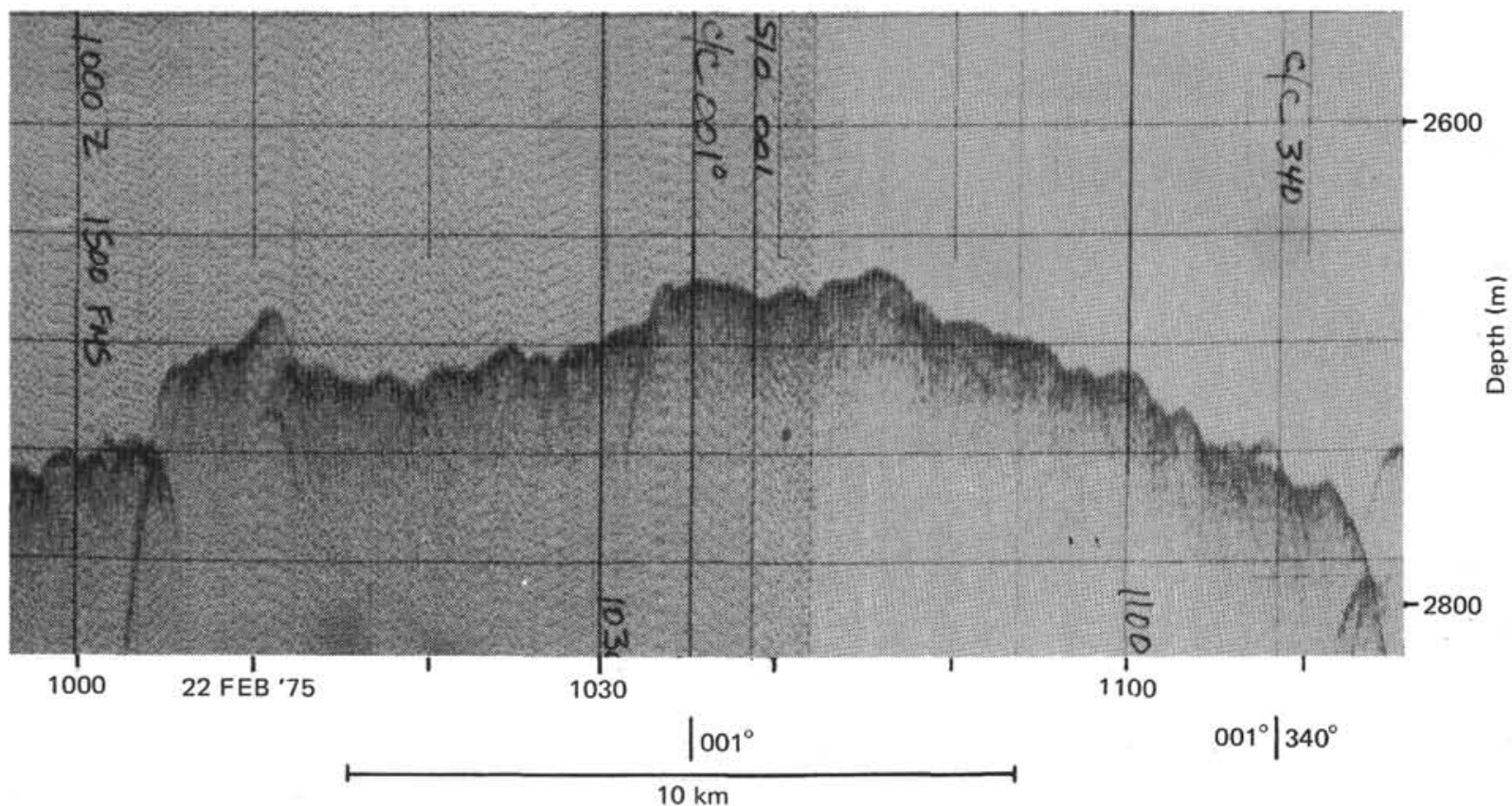

Figure 6. Precision Depth Recorder (PDR) profiles recorded while approaching the Sierra Leone Rise (see location on Figure 2). 
TABLE 2

Lithostratigraphy at Site 366

\begin{tabular}{llll}
\hline Unit & \multicolumn{1}{c}{ Lithology } & \multicolumn{1}{c}{ Cores } & \multicolumn{1}{c}{ Age } \\
\hline 1 & Nanno marls and oozes & $\begin{array}{l}\text { 1A through } 15 \mathrm{~A} \\
(0 \text { to } 136 \mathrm{~m})\end{array}$ & $\begin{array}{l}\text { Pleistocene through } \\
\text { middle Miocene } \\
\text { Middle Miocene } \\
\text { through middle }\end{array}$ \\
2 & $\begin{array}{l}\text { Cyclic alternations of nanno } \\
\text { oozes or chalks and marls or } \\
\text { pelagic clays }\end{array}$ & $\begin{array}{l}5 \text { through } 16 \\
(136 \text { to } 480 \mathrm{~m})\end{array}$ & $\begin{array}{l}\text { Eocene } \\
\text { Middle Eocene } \\
\text { through early } \\
\text { Eocene }\end{array}$ \\
& $\begin{array}{l}\text { Cyclic alternations of nanno } \\
\text { chalks and porcellanites/ } \\
\text { cherts or siliceous lime- } \\
\text { stones } \\
\text { Limestones and marlstones }\end{array}$ & $\begin{array}{l}\text { (480 to } 679.5 \mathrm{~m}) \\
(6879.5 \text { to } 850.5 \mathrm{~m})\end{array}$ & $\begin{array}{l}\text { Early Eocene to } \\
\text { Upper Cretaceous }\end{array}$ \\
\hline
\end{tabular}

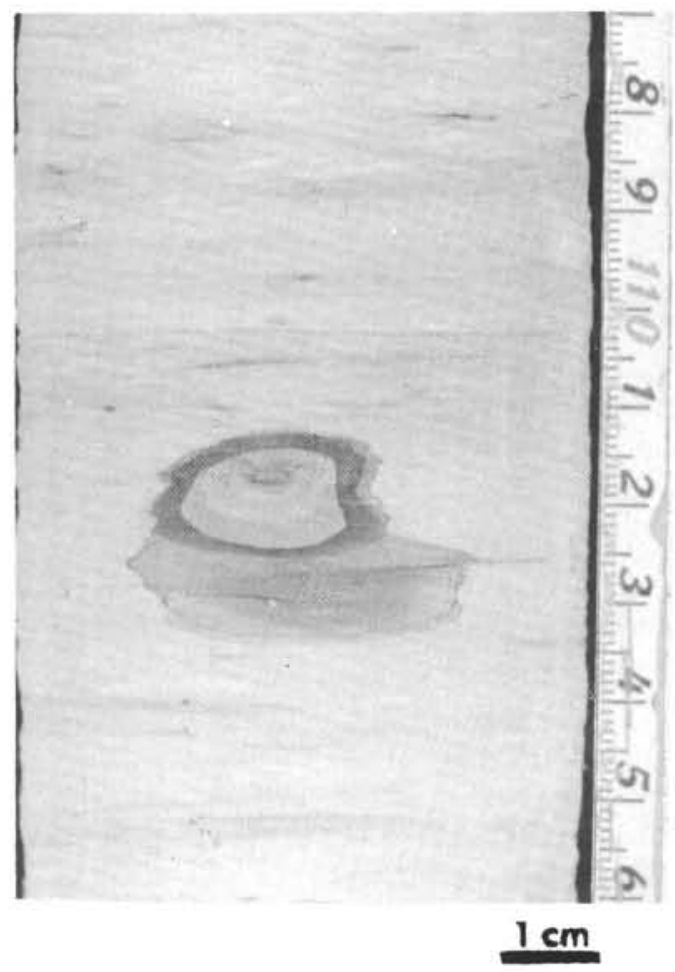

Figure 7. Section of Sample 41-366-21-2, 117 $126 \mathrm{~cm}$, showing manganese (?) liesegang halos which are common throughout Unit 2.

uppermost occurring in Core 26, Section $2(567 \mathrm{~m})$. The youngest cherts occur in Core 19, Section $1(508 \mathrm{~m})$.

The porcellanite is light gray (N7) and shows subconchoidal fracturing. These often grade into light olive-gray (5Y6/1) chert, especially in burrows and within thin laminae. A typical sequence consists of about $15 \mathrm{~cm}$ of chalk, overlying about $10 \mathrm{~cm}$ of silicified limestone, or porcellanite. Chert nodules, when present, occur in the bottom $5 \mathrm{~cm}$ of the siliceous limestone or porcellanite.

By Core $29(594 \mathrm{~m})$ the nannofossil chalk grades into an argillaceous limestone-siliceous limestone $\left(\mathrm{CaCO}_{3}\right.$ ranges from $68 \%$ to $84 \%$ ). These are light gray (N8) to light greenish gray $(5 \mathrm{GY} 8 / 1)$ and have abundant ferromanganese(?) flecks, streaks, and laminae. The limestone is faintly laminated and contains abundant burrows. Thin interbeds of shale occur within the argillaceous limestone. Recrystallized calcite and calcite overgrowths on nannofossils are common in smear slides. Each cycle in this interval averages about 25 to $40 \mathrm{~cm}$ in length (4 to 6 cycles per core section), with about two-thirds of the cycle being the argillaceous limestone and one-third being the chert, porcellanite, or siliceous limestone.

The biogenic compositions of the two facies (siliceous limestone and argillaceous limestone), based on smear-slide descriptions, are quite similar; the clay and silica content are the main differences between facies. Both lithologies have abundant euhedral and subhedral calcite, rare foraminifers and radiolarians, and common nannofossils.

\section{Unit 4-Limestone and Marlstone (Cores 38 through 55)}

The principal lithologies of Unit 4 are greenish gray $(5 \mathrm{G} 6 / 1)$ argillaceous limestone and light gray (N7) siliceous limestone which grade with depth into light olive-gray (5Y6/1) marlstone (Core 48, Section 3, 776 $\mathrm{m}$ ) having carbonate contents between $62 \%$ and $71 \%$. This unit is thinly laminated and burrowed, with common thin (2 to $4 \mathrm{~cm}$ ) shaly interbeds. Smear slides contain rare foraminifers and nannofossils, and abundant recrystallized calcite. Radiolarians become very rare to absent in this unit. Disseminated pyrite occurs in zones from Cores 44 through 46.

Thin $(\sim 5 \mathrm{~cm})$ interbeds and lenses of calcarenite occurs from Core 41, Section $6,130 \mathrm{~cm}$, through Core 44, Section 5. These calcarenites contain abundant foraminifers $\left(\mathrm{CaCO}_{3}\right.$ content around $\left.75 \%\right)$ with rare to common clay. They could represent lag deposits caused by current winnowing. The calcarenite lenses are commonly rimmed by a darker halo.

By Core 48 , Section $3(776 \mathrm{~m})$, the above siliceous and argillaceous limestones have graded into a light olive-gray marlstone $\left(\mathrm{CaCO}_{3}\right.$ content $\left.60 \%\right)$. The marlstone differs from the overlying limestone not only in composition but also in degree of cementation. Burrows, especially Chondrites and Zoophycos, are well developed in this lithology.

\section{Summary}

Overall, the sediments recovered at Site 366 provide an almost continuous record of open-marine pelagic conditions for the entire Cenozoic. The high $\mathrm{CaCO}_{3}$ content of the section indicates that the Sierra Leone Rise has been above the CCD throughout the Cenozoic.

Unit 4 contains evidence of current winnowing, the only apparent breaks in sedimentation found in the entire section. The induration of the sediments and the occurrence of flattened burrows suggest a considerable amount of compaction.

The lower to middle Eocene section (Unit 3) consists of chalk and limestone of varying clay content. The variations in relative proportions of clay and $\mathrm{CaCO}_{3}$ are interpreted as the result of $\mathrm{CaCO}_{3}$ dissolution, and by dilution by terrigenous material (Dean et al., this volume). Cycles of $\mathrm{CaCO}_{3}$ and clay, with periodicities on the order of 7000 to 21,000 years, are modified by post-depositional cementation by $\mathrm{SiO}_{2}$ and $\mathrm{CaCO}_{3}$. 
Sediments with the highest $\mathrm{CaCO}_{3}$ content were selected for both $\mathrm{CaCO}_{3}$ and $\mathrm{SiO}_{2}$ cementation, during diagenesis, which in alternations of siliceous limestone, and either chalk, marl, or argillaceous limestone, all containing more clay than the siliceous limestone.

The middle Eocene to middle Miocene chalks and marls (Unit 2) are also cyclic, but the cycles are relatively simple variations in proportions of $\mathrm{CaCO}_{3}$ and clay and unmodified by $\mathrm{CaCO}_{3}$ of $\mathrm{SiO}_{2}$ cementation. Here, the two lithologies which make up a cycle, nannofossil ooze or chalk alternating with nannofossil marl or pelagic clay, are also interpreted as being mainly the result of $\mathrm{CaCO}_{3}$ dissolution. The periodicities of these dissolution cycles are on the order of 30,000 to 50,000 years.

The middle Miocene to Holocene sediments (Unit 1) probably represent conditions prevailing on the Sierra Leone Rise today. Unfortunately, drilling disturbance was too intense to allow interpretation of any cyclicity.

The section sampled at Site 366 represents an excellent example of progressive diagenesis with depth in pelagic carbonate sediments (see Gardner et al., this volume). Unit 1 shows no obvious diagenetic features and minimal compaction, but Unit 2 shows evidence of compaction in some zones. This is followed in Unit 3 by calcite overgrowths on nannofossils, an increase in the number of zones showing compaction, and extensive cementation by $\mathrm{CaCO}_{3}$ and $\mathrm{SiO}_{2}$. Unit 4 shows extensive calcite overgrowths on nannofossils, sparry calcite infilling of foraminifer tests and almost all of the unit shows evidence of compaction and cementation.

The carbonate cycles of Site 366 can be correlated with equivalent cycles recovered from Leg 40 , Site 363 and $362 \mathrm{~A}$, on the Walvis Ridge and Leg 39 , Site 354 , on the Ceará Rise (see Dean et al., this volume).

\section{GEOCHEMICAL MEASUREMENTS}

\section{Carbon/Nitrogen Measurements}

A method for shipboard measurements of organic carbon to total nitrogen ratios was developed while at this site using the Hewlett-Packard Model 185B CHN Analyzer. Details of the method are given in the Introduction (this volume).

Results for organic carbon and carbon:nitrogen determinations for Site 366 are given in Table 3. All weight percentages have been converted to total dry weight basis or atomic ratio for carbon:nitrogen. The sparsity of sampling in the upper sediment as well as low precision encountered in the method prevents any meaningful interpretation. An electronic problem in the CHN Analyzer prevented analyses of sediments from Hole 366A.

\section{Interstitial Gas Analysis}

No cores at Site 366 yielded noticeable gas; however, gas bubbles formed in Cores $8 \mathrm{~A}, 19 \mathrm{~A}$, and $21 \mathrm{~A}$ while waiting to be split. Sampling both through the end caps and liner failed to detect light hydrocarbons. Sections $8 \mathrm{~A}-6$ and $18 \mathrm{~A}-4$ had elevated $\mathrm{CO}_{2}$. Assuming 300 ppm $\mathrm{CO}_{2}$ for ocean air, the $\mathrm{CO}_{2}$ concentration was 1817 ppm of gas recovered for Section 8A-6 and 1631 ppm for Section 18A-4. Gas in Section 21A-1 had no significant increase in $\mathrm{CO}_{2}$.

\section{Carbonate Bomb Measurements}

The results of the "Carbonate Bomb" measurements for percent $\mathrm{CaCO}_{3}$ are given in Table 4 and Figure 8 for Site 366 . In order to help interpret the wide variations in percent $\mathrm{CaCO}_{3}$, the lithology at each sampling interval in the cores is also given in Table 5. This lithology is based on the visual description and smearslide examination made as soon as the cores were split.

\section{Interstitial Water Chemistry}

At Site 366, five whole sections, $6 \mathrm{~cm}$ long, were squeezed to collect samples for interstitial water chemistry. By Core 20-1, the sediment is so lithified that excessive hydraulic pressures are necessary, hence preventing further sampling down in the section. An additional six samples were squeezed at Hole $366 \mathrm{~A}$. Results are tabulated in Table 5 and graphic representation appears in Figure 9.

\section{PHYSICAL PROPERTIES}

Lithologic variations throughout the sequence are strongly reflected in the physical properties data (see Trabant, this volume, for description of techniques used). This site allows a comparison of physical properties to be made between siliceous and calcareous sediments. No major unconformities were discovered at this site, thus all changes in physical properties may be attributed directly to primary variations in sedimentation and to diagenetic effects caused by compaction, cementation, and dissolution.

\section{Bulk Properties}

Bulk-property measurements were taken from one section of each core for bulk density, water content, void ratio, porosity, and specific gravity solids. Sound velocity and shear strength data were obtained, where feasible, prior to sampling for bulk properties measurements.

Porosities are equitable values in the description of sediment bulk properties but any of the other parameters would have been just as descriptive. A plot of porosities against depth is shown in Figure 10. The lithologic boundaries correspond with sharp changes in porosity values. Each unit is characterized by definite porosity ranges. The lowest values (10\% to $15 \%)$ occur within the interbedded cherts and porcellanites of Unit 3. Two zones with relatively high porosities occur within the early Miocene $(150$ to $250 \mathrm{~m})$ and early Eocene $(600$ to $700 \mathrm{~m})$ where accumulation rates were high 40 and $60 \mathrm{~m} / \mathrm{m} . y$., respectively. Porosities within the lower Miocene section of nannofossil ooze and marl range between $60 \%$ and $65 \%$. The chalk and limestone within the lower Eocene interval have porosities ranging between $35 \%$ and $45 \%$. It is possible that overlying chert layers and argillaceous limestone layers have sealed off this lower zone and subsequently reduced the process of compaction by preventing the upward flux of pore water. 
TABLE 3

Carbon and Nitrogen Analyses at Site 366

\begin{tabular}{|c|c|c|c|c|c|c|}
\hline \multirow{2}{*}{$\begin{array}{c}\text { Sample } \\
\text { (Interval in } \mathrm{cm} \text { ) }\end{array}$} & \multirow{2}{*}{$\begin{array}{l}\text { Depth } \\
\text { (m) }\end{array}$} & \multicolumn{2}{|c|}{$\begin{array}{c}\% \text { Organic C } \\
\text { (total dry wt. basis) }\end{array}$} & \multicolumn{2}{|c|}{$\begin{array}{c}\mathrm{C} / \mathrm{N} \\
\text { (atomic ratio) }\end{array}$} & \multirow[b]{2}{*}{ Remarks } \\
\hline & & $x$ & SD & $x$ & SD & \\
\hline $3-4,84-85$ & 126 & 0.046 & 0.010 & 7.0 & 1.0 & \\
\hline $3-5,76-77$ & 127 & 0.049 & 0.012 & 4.8 & 0.4 & \\
\hline $7-3,71-72$ & 394 & 0.113 & 0.020 & 2.7 & 1.0 & \\
\hline $12-3,76-77$ & 441 & 0.094 & 0.003 & 5.5 & 0.4 & Residue from $\mathrm{CO}_{3} \mathrm{Bomb}$ \\
\hline $16-2,7-8$ & 471 & 0.082 & 0.060 & 4.4 & 1.8 & \\
\hline $19-2,103-104$ & 508 & 0.129 & 0.021 & 7.6 & 1.2 & \\
\hline $22-1,49-50$ & 528 & 0.148 & 0.017 & 6.6 & 1.9 & Residue from $\mathrm{CO}_{3} \mathrm{Bomb}$ \\
\hline $25-2,60-61$ & 565 & 0.106 & 0.014 & 4.6 & 1.6 & \\
\hline $26-2,1-2$ & 574 & 0.567 & 0.001 & 11.6 & 1.8 & Green clay layer \\
\hline $31-2,111-112$ & 620 & 0.084 & 0.005 & 7.4 & 1.2 & \\
\hline $34-5,133-134$ & 651 & 0.080 & 0.014 & 6.4 & 1.9 & \\
\hline $37-3,25-26$ & 675 & 0.100 & 0.014 & 3.0 & 1.2 & \\
\hline $40-3,77-78$ & 705 & 0.047 & 0.013 & 8.0 & 3.6 & \\
\hline $44-3,86-87$ & 740 & 0.126 & 0.030 & 5.0 & 2.7 & \\
\hline
\end{tabular}

\section{Shear Strengths}

Only a few shear strength measurements were obtained to a depth of 160 meters below the sea floor due to the limited upper sequence of soft unconsolidated sediments, and the disturbed nature of these samples. Variations in shear strength (cohesion as measured by the miniature-vane apparatus) strongly reflect the lithologic change from Unit 1 to Unit 2. Shear strengths range between 0.3 and $1.8 \mathrm{~kg} / \mathrm{cm}^{2}$ with the nannofossil marl and ooze of Unit 1, whereas they increase to over $5.0 \mathrm{~kg} / \mathrm{cm}^{2}$ within the firmer chalk and marl of Unit 2.

\section{Acoustic Velocities}

Compressional wave velocities $(\mathrm{Vp})$ were obtained using the Hamilton Frame velocimeter. Soft sediments were tested in split liners, but the more indurated chalk, limestone, and chert were cut into small cubes ( 20 to 50 $\mathrm{cm}^{3}$ each) and velocities obtained both vertically and horizontally.

A plot of velocity versus depth is presented in Figure 11. These show a slow increase in velocity down to 400 meters, where nannofossil ooze and marl grade into indurated chalk. Velocities at this depth begin increasing rapidly to nearly $3.0 \mathrm{~km} / \mathrm{sec}$, and interlayered chert produces velocities at and above 4.0 $\mathrm{km} / \mathrm{sec}$. Below this interval a noticeable reduction in velocities is observed between a depth of 600 to 700 meters which corresponds to the previously discussed high porosity zone. Velocities within the deepest sediments penetrated range between 2.8 and 2.9 $\mathrm{km} / \mathrm{sec}$.

Anisotropy between horizontal and vertical measurements of $\mathrm{Vp}$ within chert layers is quite large. Vertical velocities are markedly lower, as was found to be the case for similar cherts retrieved during Leg 32 (Site 303). This directional dependence was attributed by Marshall (1975) to the presence of unsilicified or less silicified (porcellanite) interlayers within the chert.

\section{Summary}

Mass physical properties data for Site 366 (summarized in Trabant, this volume) do not display simple relationships which can be correlated with either depth or time. Diagenetic processes other than compaction appear to have taken place.

The upper Eocene chert and limestone section has higher velocities $(\mathrm{Vp})$ and lower porosities than adjacent lithologic units.

Lower Eocene sediments are highly porous, considering the depth of burial $(600$ to $700 \mathrm{~m})$ and the $\mathrm{Vp}$ values are consequently low (1.9 to $2.3 \mathrm{~km} / \mathrm{sec})$. This lower Eocene section can be considered under consolidated in terms of physical property data, whereas the overlying chert and limestone unit appears overcompacted due to cementation effects.

\section{BIOSTRATIGRAPHY}

The most noteworthy feature of this site is the biostratigraphic continuity of the Cenozoic, based on identification of the zonal succession of foraminifers, nannofossils, and radiolarians. Only minor hiatuses were detected. A substantial portion of the Cenozoic section contains well-preserved diatom assemblages as well. Consequently, there exists at this site an excellent opportunity to establish a more precise diatom zonation for the tropical Atlantic, and to determine precise correlations between the zonal boundaries for all of the microfossil groups. The proposed correlation between the principal zonal successions is included in the biostratigraphic synthesis (Cepek et al., this volume).

The Cretaceous-Tertiary boundary occurs near the base of the site, but was not sampled due to technical difficulties (see operations resume). Two foraminiferal zones (Globorotalia eugubina Zone- $G$. pseudobulloides Zone, and Abathomphalus mayaroensis Zone) and two nannofossil zones (Markalius inversus Zone and Nephrolithus frequens Zone/Micula mura Zone), which correspond to the lowermost Danian and uppermost Maestrichtian stages, were not recovered. Presumably, these zones are represented in the unsampled stratigraphic intervals (about $20 \mathrm{~m}$ thick) at the base of the hole. The evidence suggests that there is no depositional hiatus at the Cretaceous/Tertiary boundary on the Sierra Leone Rise. 
TABLE 4

$\% \mathrm{CaCO}_{3}$ - Carbonate Bomb Analyses, for Site 366

\begin{tabular}{cccc}
\hline Sample & Depth & & \\
(Interval in cm) & $(\mathrm{m})$ & $\% \mathrm{CaCO}_{3}$ & Lithology \\
\hline
\end{tabular}

Hole 366

3-1, 25-26

3-2, $25-26$

$3-4,84-85$

3-5, 82-83

4-2, 136-137

6-3, 64-65

$7-3,71-72$

9-3, 61-62

10-2, 58-59

$11-1,52-53$

$12-3,76-77$

$13-2,82-83$

$14-3,82-83$

$15-1,54-55$

$16-2,7-8$

19-1, 103-104

20-2, 131-132

$21-2,81-82$

22-1, 49-50

23-1, 63-64

23-1, 68-69

24-2, 105-106

24-2, 110-111

$25-2,60-61$

$26-3,81-82$

$27-2,79-80$

28-3, 58-59

29-2, 37-38

30-1, 111-112

$31-2,134-135$

$34-5,133-134$

35-3, 113-114

36-3, 33-34

$37-3,25-26$

$38-3,47-48$

39-3, 123-124

40-3, 77-78

41-3, 76-77

42-3, 123-124

43-3, 128-129

$44-3,24-25$

45-3, 43-44

$46-3,64-65$

47-3, $42-43$

$48-3,44-45$

49-3, 85-86

50-3, 107-108

51-2, 77-78

120
121
125
127
249
380
391
411
415
430
439
449
457
467
477
508
517
525
534
544

544
552
552
563
574
579
590
599
613
619
650
655
665
673
683
693
702
712
722
731
740
750
764
769
778
788
798
805
7

72

83

59

62

79

79

83

79

72

75

58

54

14

83

73

83

79

92

83

37

87

37

79

40

73

62

62

67

29

14

55

56

58

37

46

55

Hole 366A

$2-3,66-67$
$3-3,63-64$
$4-3,24-25$
$5-3,76-77$
$7-3,44-45$
$8-3,104-105$
$9-3,77-78$
$10-1,54-55$
$11-3,54-55$
$12-3,110-111$
$14-3,91-92$
$15-3,103-104$
$16-3,140-141$
$17-3,90-91$

$17-3,90-91$

\begin{tabular}{rll}
10 & 56 & Nanno marl \\
19 & 68 & Nanno marl \\
28 & 49 & Nanno marl \\
38 & 66 & Nanno marl \\
57 & 46 & Nanno marl \\
67 & 92 & Nanno ooze \\
76 & 86 & Nanno ooze \\
90 & 84 & Nanno ooze \\
95 & 83 & Nanno ooze \\
105 & 72 & Nanno ooze \\
124 & 68 & Nanno ooze \\
134 & 60 & Nanno ooze \\
145 & 60 & Nanno ooze \\
152 & 72 & Nanno ooze \\
\hline
\end{tabular}

TABLE 4 - Continued

\begin{tabular}{|c|c|c|c|}
\hline $\begin{array}{c}\text { Sample } \\
\text { (Interval in } \mathrm{cm} \text { ) }\end{array}$ & $\begin{array}{c}\text { Depth } \\
\text { Subbottom } \\
\text { (m) }\end{array}$ & $\% \mathrm{CaCO}_{3}$ & Lithology \\
\hline
\end{tabular}

Hole 366A - Continued

\begin{tabular}{llrl}
$18-3,83-84$ & 162 & 81 & Chalk \\
$20-3,104-105$ & 186 & 77 & Chalk \\
$21-3,74-75$ & 190 & 79 & Chalk \\
$23-1,26-27$ & 205 & 7 & Pelagic clay \\
$23-1,45-46$ & 205 & 71 & Chalk \\
$23-3,72-73$ & 208 & 80 & Chalk \\
$23-3,78-79$ & 208 & 22 & Clay \\
$24-2,95-96$ & 223 & 80 & Chalk \\
$26-3,113-114$ & 240 & 80 & Chalk \\
$27-3,108-109$ & 247 & 78 & Chalk \\
$28-3,76-77$ & 257 & 76 & Chalk \\
$29-3,72-73$ & 266 & 79 & Chalk \\
$30-3,54-55$ & 276 & 73 & Chalk \\
$31-3,84-85$ & 287 & 81 & Chalk \\
$33-3,84-85$ & 305 & 76 & Chalk \\
$34-3,78-79$ & 314 & 76 & Chalk \\
$35-3,73-74$ & 323 & 80 & Chalk \\
$36-3,53-54$ & 334 & 69 & Clay \\
$37-3,96-97$ & 343 & 84 & Nanno ooze \\
$38-3,45-46$ & 353 & 85 & Chalk \\
$39-3,91-92$ & 364 & 86 & Chalk \\
\hline
\end{tabular}

\section{Foraminifers}

\section{Cenozoic}

Foraminiferal assemblages of Cores 1, 2, 1A, 2A, and $3 \mathrm{~A}$ are Pleistocene in age. They contain rich and diverse assemblages of planktonic foraminifers. However, specimens of Globigerina bulloides and Globorotalia inflata are rare. This assemblage has a tropicalsubtropical character and very good preservation.

The presence of pink Globigerina ruber and Globigerinoides rubescens in Cores 1 and $1 \mathrm{~A}$ indicates a late Pleistocene age but the occurrence of Globorotalia tumida flexuosa gives a minimum age of $80,000 \mathrm{yr}$ B.P.. We have subdivided the Pleistocene sequence (Globorotalia truncatulinoides Zone) into Globorotalia crassaformis viola Subzone, the Globorotalia crassaformis hessi Subzone, and the Globigerina calida calida Subzone.

Benthic foraminifera are scarce and represented by Pullenia, Sphaeroidina, Cassidulina, Uvigerina, thinwalled miliolids and nodosariids, all deep-water forms.

Pliocene assemblages were recovered in Cores $4 \mathrm{~A}$ through 9A. The upper zone of Pliocene (the Globorotalia tosaensis Zone) was identified in Core 4A, Section 1 through 3 , but the index species is missing.

The Globorotalia miocenica Zone is found in Cores $4 \mathrm{~A}$ through $6 \mathrm{~A}$ and was divided into two subzones; the Globorotalia exilis Subzone and the Globigerinoides fistulosus Subzone.

The assemblage of planktonic foraminifers from Cores 6A through 9A are assigned to the Globorotalia margaritae evoluta Zone.

Tropical and subtropical species of planktonic foraminifers are well-preserved, abundant and, with the 


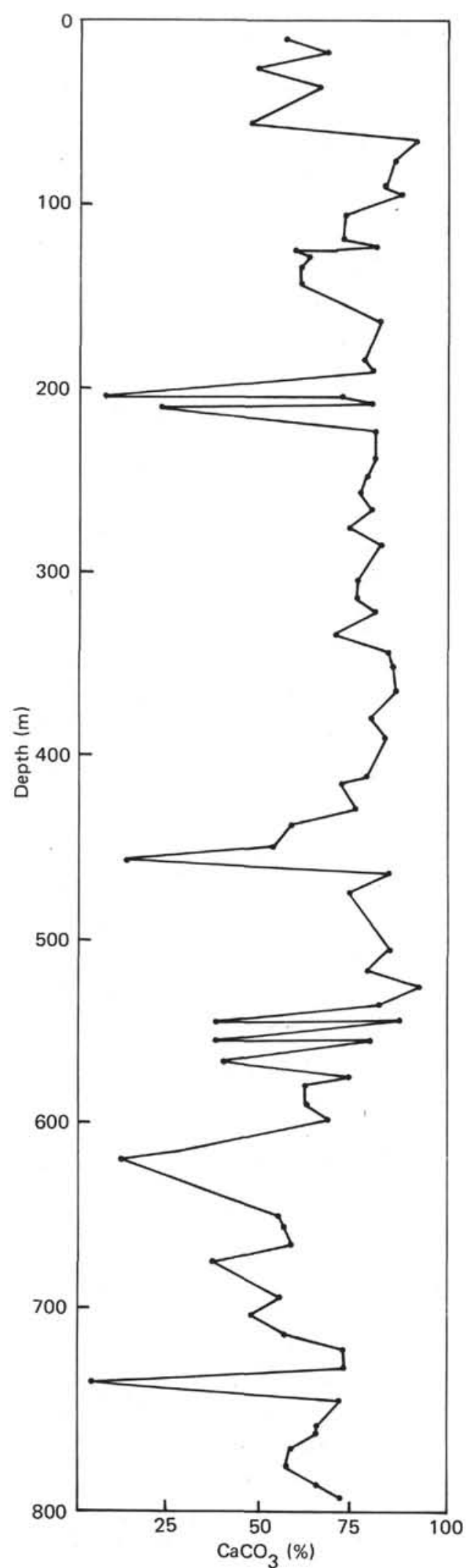

Figure 8. Plot of $\mathrm{CaCO}_{3}$ versus depth at Site 366.

scarcity of benthic foraminifers, testify to open marine pelagic environments.
Cores $10 \mathrm{~A}, 11 \mathrm{~A}$, and the upper part of the $12 \mathrm{~A}$ have rich assemblages of tropical-subtropical planktonic foraminifers which are correlated with the Globorotalia margaritae margaritae Zone, a transitional zone between Pliocene and Miocene. Globorotalia tumida tumida was not found. Evidently, in the Sierra Leone Rise section as well as in other areas of the Atlantic and Caribbean regions, this species appears later in the Pliocene.

Faunas of lower and upper Miocene are well developed and can be divided into a number of zones, whereas the section of middle Miocene is condensed and only three zones are recognized. Our use of upper Miocene includes the Messinian and Tortonian stages. The abundant planktonic foraminifers of the Globorotalia plesiotumida Zone (Cores $12 \mathrm{~A}$ and $13 \mathrm{~A}$ ) are well or moderately preserved and have tropical to subtropical affinities. Low benthic/planktonic foraminifer ratios suggest deep-water pelagic conditions.

The Globorotalia acostaensis Zone (Cores 3, 14A, and $15 \mathrm{~A}$, upper part) has numerous specimens of Globorotalia acostaensis, but $G$. plesiotumida, $G$. dutertrei, and Candeina nitida nitida are absent. The microfauna has a tropical to subtropical affinity, good preservation, and indicates deep-water conditions.

Upper and middle Miocene sediments are separated by a small hiatus with three zones missing: the Globorotalia continuosa Zone; Globigerina nepenthes/Globorotalia siakensis Zone; and the Sphaeroidinellopsis subdehiscens/Globigerina druryi Zone.

Middle Miocene faunas are found in Cores $15 \mathrm{~A}$ and 16A. They belong to the Globorotalia fohsi lobata Zone, Globorotalia fohsi/fohsi Zone, and Globorotalia peripheroronda Zone. Good to moderately preserved faunas are seen throughout this interval. A peculiar feature of the microfauna is the presence of $\mathrm{Cl}$. bermudezi and a scarcity of Orbulinas. We separated the middle and lower Miocene by a hiatus within Core 16A, which corresponds to two zones: the Orbulinas suturalis-Globorotalia peripheroronda Zone and the Praeorbulina glomerosa Zone.

The only zone of the lower Miocene not found is the Praeorbulina glomerosa Zone. Cores 16A through 18A are attributed to the Globigerinatella insueta-Globigerinoides trilobus Zone. The specific composition of planktonic foraminifers enables a precise zonal definition even though the zonal marker $(G$. insueta) is extremely rare. Cores $20 \mathrm{~A}$ through $22 \mathrm{~A}$ contain faunas correlated with the Globigerinita stainforthi-Globigerinita dissimilis zones. Cores 23A through 26A represent the Globigerinita dissimilis Zone. Cores 4 and 26A, 28A, Section 1 include the oldest Miocene microfauna, the Globigerinoides primordius-Globorotalia kugleri Zone. We consider the lower Miocene planktonic foraminifers to be tropical to subtropical assemblages. The ratios between planktonic and benthic foraminifers indicates deep-water conditions through the early Miocene.

Rich planktonic foraminiferal assemblages in the upper part of the section allowed us to carry out the standard Oligocene zonation but in the lower part of the section foraminifers are fairly rare, badly preserved, and our zonation becomes tentative. 
TABLE 5

Summary of Shipboard Geochemical Data From Interstitial Water at Site 366

\begin{tabular}{|c|c|c|c|c|c|c|c|}
\hline $\begin{array}{c}\text { Sample } \\
\text { (Interval in } \mathrm{cm} \text { ) }\end{array}$ & $\begin{array}{l}\text { Depth } \\
\text { (m) }\end{array}$ & $p \mathrm{H}$ & $\begin{array}{l}\text { Alkalinity } \\
(\mathrm{meq} / \mathrm{kg})\end{array}$ & $\begin{array}{l}\text { Salinity } \\
(\% \circ)\end{array}$ & $\begin{array}{c}\mathrm{Ca}^{++} \\
(\mathrm{mmoles} / \mathrm{l})\end{array}$ & $\underset{(\mathrm{mmoles} / \mathrm{l})}{\mathrm{Mg}^{++}}$ & $\begin{array}{c}\mathrm{Cl} \\
(\%)\end{array}$ \\
\hline \multicolumn{8}{|l|}{ Hole 366} \\
\hline $1-2,0-6$ & 1.5 & 7.30 & 3.43 & 35.2 & 11.72 & 52.90 & 19.24 \\
\hline $3-5,0-6$ & 131.5 & 6.86 & 5.90 & 35.5 & 19.90 & 54.57 & 19.11 \\
\hline $4-2,144-150$ & 248.5 & 6.79 & 5.82 & 35.8 & 24.19 & 56.53 & 17.98 \\
\hline $5-5,142-150$ & 375.5 & 6.78 & 5.42 & 36.0 & 27.03 & 56.24 & 19.38 \\
\hline $10-4,144-150$ & 419.5 & 7.07 & 4.22 & 38.0 & 33.67 & 56.24 & 19.31 \\
\hline $15-2,0-10$ & 462.5 & 6.82 & 4.47 & 36.3 & 34.92 & 57.41 & 19.31 \\
\hline $30-1,135-150$ & 510.0 & 6.85 & 0.60 & 36.0 & 42.75 & 56.39 & 19.05 \\
\hline \multicolumn{8}{|l|}{ Hole $366 \mathrm{~A}$} \\
\hline $1-3,144-150$ & 4.5 & 7.52 & 3.22 & 35.2 & 11.34 & 53.84 & 19.48 \\
\hline $5-4,144-150$ & 40.5 & 7.13 & 4.06 & 35.8 & 13.42 & 54.58 & 19.72 \\
\hline $9-5,144-150$ & 80.0 & 7.03 & 4.70 & 35.8 & 15.80 & 55.39 & 19.96 \\
\hline $14-5,144-150$ & 127.5 & 6.93 & 5.98 & 36.0 & 20.06 & 56.86 & 19.82 \\
\hline $20-2,144-150$ & 180.0 & 6.84 & 6.47 & 36.0 & 23.82 & 58.12 & 19.82 \\
\hline $26-3,144-150$ & 238.5 & 6.76 & 6.99 & 36.3 & 28.18 & 59.15 & 20.06 \\
\hline
\end{tabular}

The uppermost zone (Globorotalia kugleri Zone s. s.) of the Oligocene appears in Cores 28A and 29A. Sample 29A, CC contains planktonic foraminifers transitional to the microfauna of the underlying Globigerina ciperoensis Zone. Cores 30A through 33A, Section 1, are correlated to the Globigerina ciperoensis Zone. Cores 33A through 39A, Section 1, belong to the Globorotalia opima opima Zone. Sediments of the Globorotalia kugleri s. s., Globigerina ciperoensis, and Globorotalia opima opima zones are marked by abundant or common planktonic foraminifers with good to moderate states of preservation, suggesting tropical to subtropical conditions.

By contrast, planktonic foraminifers of the lower part of the Oligocene (Cores 39A and 5 through 9) are few or even rare with poor to moderate preservation. We have correlated the sediments of Cores $39 \mathrm{~A}, 5$, and 6 , Section 1 through 5, to the Globigerina ampliapertura Zone. Core 6, Section 6, is correlated to the Globigerina sellii Zone and Cores 7 through 9, Section 4, to the Globigerina sellii-Globigerina tapuriensis zones.

Benthic foraminifers in Cores 39A and 5 through 9 are more numerous and diverse compared to benthic microfauna or overlying zones. However, they also suggest deep-water conditions.

The upper and middle Eocene section has impoverished and poorly preserved microfaunas but the lower Eocene has relatively rich planktonic foraminifer faunas. Upper Eocene faunas are found in Cores 9, CC through 15. The uppermost zone of the upper Eocene (the Globigerina gortanii-Globorotalia centralis Zone), transitional to the Oligocene, is found in Core 10. Corroded deep-water benthic foraminifers are common. Cores 16 through 19 include comparatively diverse planktonic foraminifers and can be assigned to the Truncorotaloides rohri Zone. The microfauna is poor in underlying sediments. Core 20 is assigned to the Truncorotaloides rohri-Orbulinoides beckmanni zones. Cores 24 through 26 are assigned to the Globorotalia lehneri-Globigerapsis kugleri zones. Cores 27 and 28 belong to the Globigerapsis kugleri-
Hantkenina aragonensis zones. Representatives of Orbulinoides, Hantkenina, Globigerinatheca, and keeled Globorotalia are missing or nearly absent. Benthic foraminifers are also very rare.

A thick succession of lower Eocene sediments contain very distinctive assemblages of planktonic foraminifers and all four zones of lower Eocene are found. Cores 29 through 31 correspond to the Globorotalia palmeri Zone. Cores 32 through 37 are attributed to the undifferentiated Globorotalia palmerae/Globorotalia aragonensis zones. Cores 38 through 40 belong to the Globorotalia aragonensis Zone. Core 40, Section 5 to Core 41 , Section 5 has the microfauna of the Globorotalia formosa formosa Zone. Core 41, Section 6, contains poorly preserved planktonic foraminifers. The appearance of Globorotalia subbotinae suggests the transition to the underlying zone of this name. Cores 42 and 43 , Section 1 are characterized by a typical assemblage of the Globorotalia subbotinae Zone.

The late Paleocene is well represented but the lower Paleocene is relatively condensed. The lowermost part of the Danian stage (the Globigerina eugubina Zone and the Globigerina pseudobulloides Zone) is missing due to drilling difficulties. Cores 43 through 47, Section 2, correspond to the upper Paleocene Globorotalia velascoensis Zone. Cores 47 through 49, Section 3, are attributed to the Globorotalia pseudomenardii Zone. Core 50 is correlated to the Globorotalia pusilla Zone s.s. of the lower Paleocene. Core 51, Section 1, belongs to the Globorotalia angulata Zone. Core 51, Section 2 through CC is correlated with the Acarinina uncinata Zone of the lower Paleocene. Cores 52 and 53 have been assigned to the Globorotalia trinidadensis Zone. Chiloguembelina are common in this section. Preservation of the planktonic foraminifers is poor in the upper part of the upper Paleocene and abundance is rare to few. In the lower part of the upper Paleocene and the lower Paleocene, the preservation is better and foraminifers are more numerous. Benthic foraminifers are rare, suggesting deep-water sedimentation. 

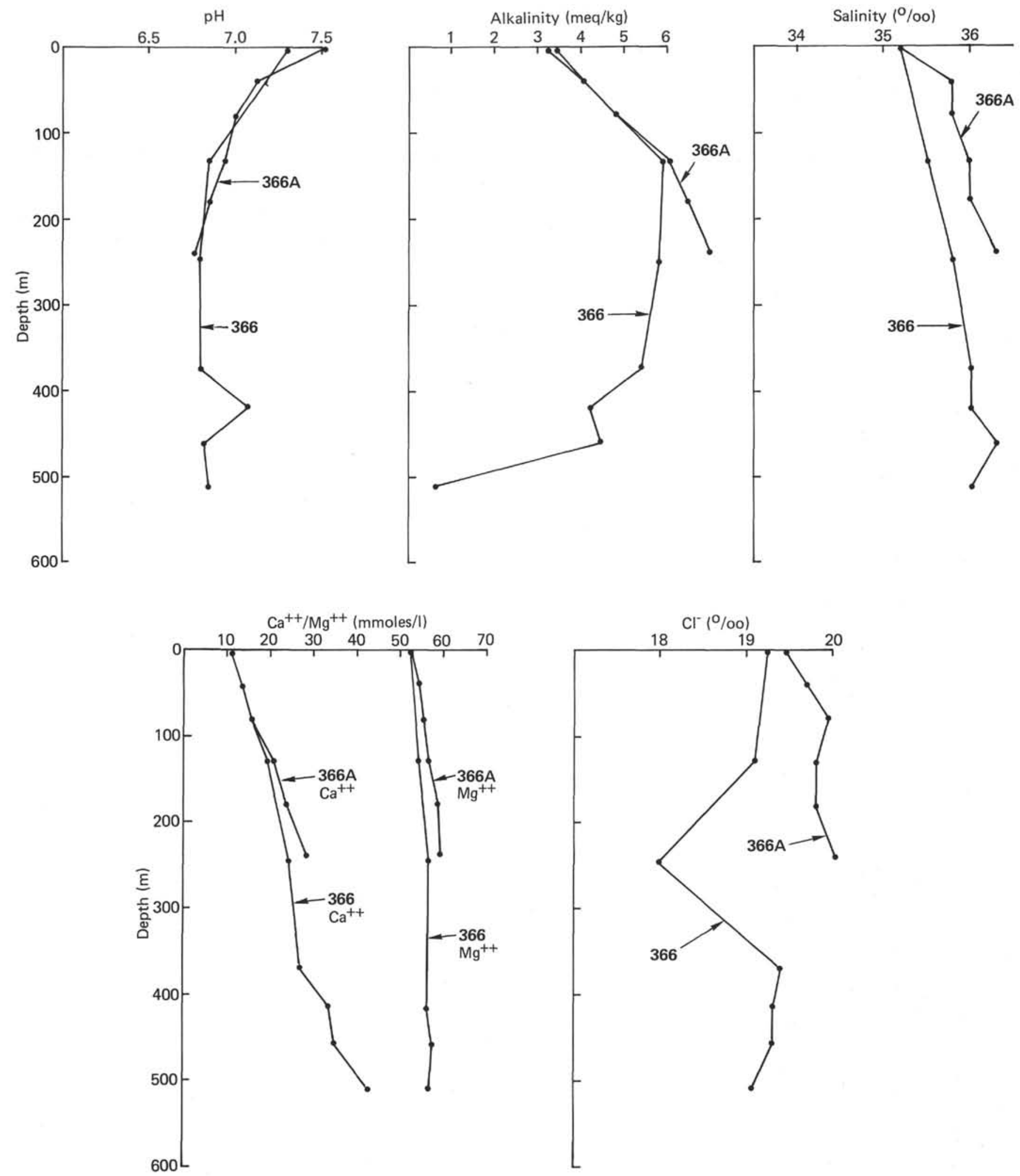

Figure 9. Plot of geochemical data from interstitial water at Site 366.

\section{Mesozoic}

Upper Cretaceous (Maestrichtian) faunas were encountered only in a sample recovered from the bit after retrieval of the drilling equipment. The depth of the sample is uncertain because the lowermost two cores were empty. The foraminifer fauna contains abundant planktonic specimens and large benthic forms. Preservation is moderate and, in comparison with Upper Cretaceous faunas from Tethys-Caribbean tropical to subtropical regions, the size of planktonic foraminifers is diminished. The Maestrichtian stage, 


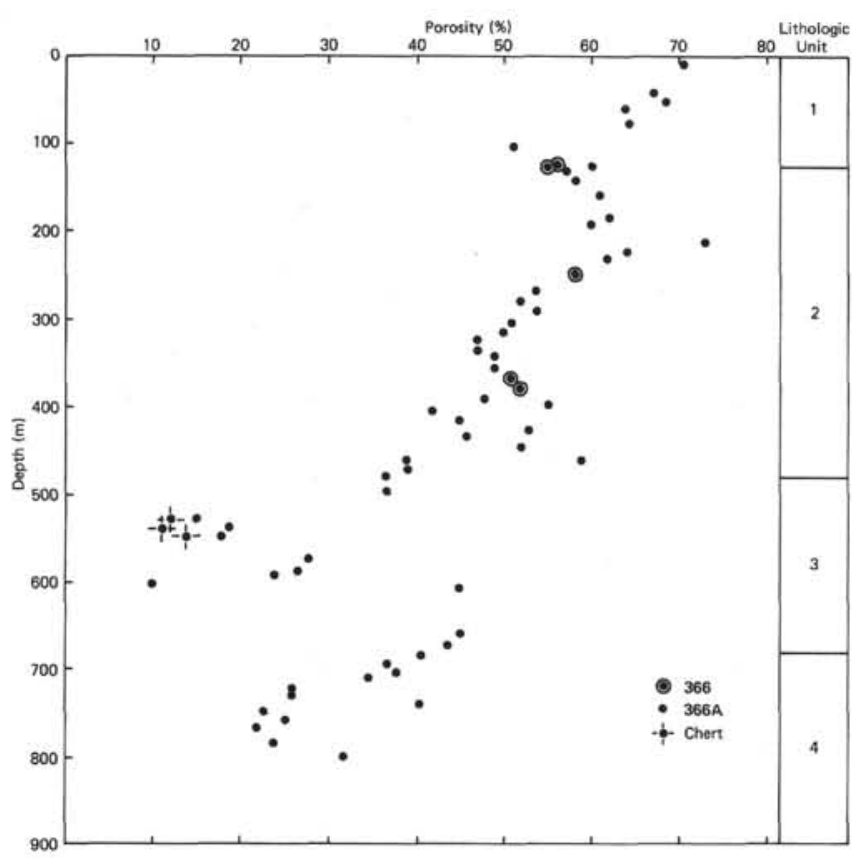

Figure 10. Plot of porosities versus depth at Site 366. species consist of agglutinated primitive forms and higher developed species as well as calcareous forms. The benthic biofacies suggests an environment not as deep as indicated for the Paleogene. The reduced size of most planktonic foraminifers suggests unfavorable conditions at the sea surface.

\section{Calcareous Nannoplankton}

A rich sequence of moderately preserved nannofloras, ranging in age from uppermost Cretaceous (Lithraphidites quadratus Zone) to Quaternary (Emiliania huxleyi Zone), was recovered at Site 366. After preliminary investigation, the nannofossils show no evidence for significant hiatuses and reworked specimens are extremely rare.

Representatives of the genus Braarudosphaera, which are indicators of shallow water and which are reported from South Atlantic legs (Leg 3, Sites 14, 17, 19, 20, 22; Leg 40 , Sites 362,363 ) in Oligocene chalks, were not found at this site.

\section{Cenozoic}

Pleistocene assemblages were recovered in Hole 366, Cores 1 and 2, and in Hole 366 A, Cores 1A, 2A, and

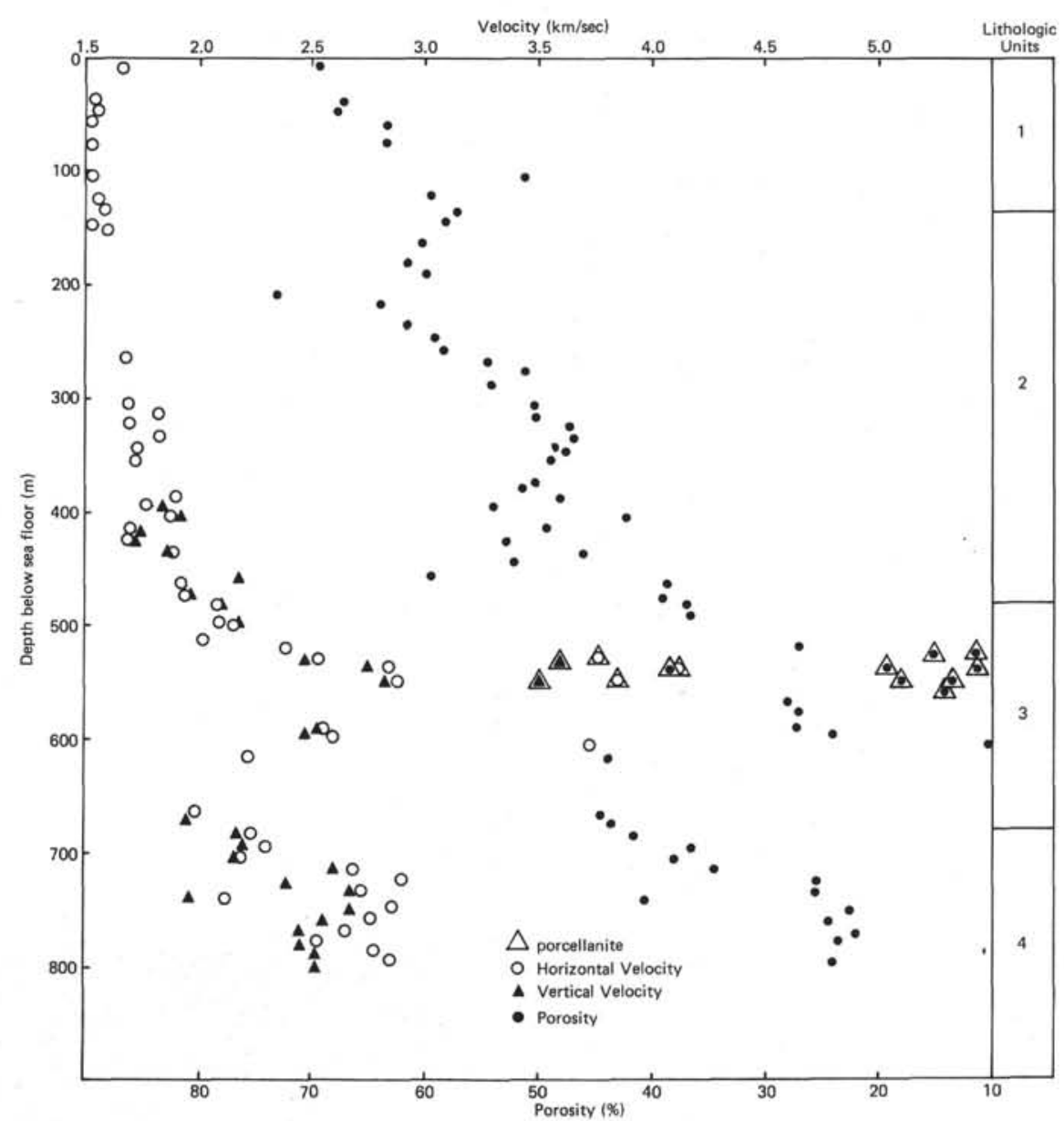

Figure 11. Plot of sonic velocity versus depth at Site 366.

Globotruncana contusa Zone is identified in these samples. Globotruncana (Abathomphalus) mayaroensis was not found in the material, so the uppermost zone of the Maestrichtian may not be represented. Benthic
$3 \mathrm{~A}$. The assemblage of coccoliths is rich and fairly well preserved. Core 1 in Hole 366 from the top to Section 1, and Core 1A in Hole 366A from the top to Section 4, belong to the Emiliania huxleyi Zone. The Gephyro- 
capsa oceanica Zone is represented in Hole 366 in the interval Core 1, Section 2, to Sample 1, CC and in Hole $366 \mathrm{~A}$ in the interval below Core 1, Section 4. Core 2 in Hole 366, and Cores $2 \mathrm{~A}$ and $3 \mathrm{~A}$ in Hole $366 \mathrm{~A}$, belong to the Emiliania ovata Subzone. No reworked coccoliths were found and no significant overgrowth or dissolution was observed.

Pliocene floras were recovered in Hole 366A to a depth of 82 meters. Common to abundant and generally well-preserved Pliocene coccolith assemblages of a rich tropical flora are indicative of the Discoaster brouweri Zone in Cores $4 \mathrm{~A}$ to $6 \mathrm{~A}$ and the Reticulofenestra pseudoumbilica Zone in Cores 7A and $8 \mathrm{~A}$. The samples are rich in discoasters, especially $D$. pentaradiatus and $D$. brouweri, which suggests warm waters. Many of the discoasters are broken in some slides but no significant overgrowth was observed. We use the Miocene/Pliocene boundary as the level between the Ceratolithus acutus Subzone and Triquetrorhabdulus rugosus Subzone which is found in Cores $9 \mathrm{~A}$ and $10 \mathrm{~A}$.

Miocene assemblages are found in Cores 3 and 4 and $10 \mathrm{~A}$ to $28 \mathrm{~A}$, giving the Miocene at least a 142.5 meter thickness. Upper Miocene coccoliths are abundant in Cores $10 \mathrm{~A}$ to $12 \mathrm{~A}$ and preservation is moderate. From Core 13A $(\sim 110 \mathrm{~m})$ to the Paleocene, the coccoliths are poorly to moderately preserved. Core $13 \mathrm{~A}$ is assigned to the Catinaster calyculus Subzone. The middle Miocene is represented in Cores $13 \mathrm{~A}$ to $18 \mathrm{~A}$. Assemblages of coccoliths are abundant, but moderately or poorly preserved. Great abundances of tropical zonal marker species, such as Discoaster hamatus, Catinaster coalitus, Discoaster exilis, and Spenolithus heteromorphus aid zonation. Cores 20A to $28 \mathrm{~A}$ and Core 4 are lower Miocene and the floras indicate the presence of the Helicopontosphaera ampliaperta Zone, Sphenolithus belemnos Zone, and Triquetrorhabdulus carinatus Zone. Specimens are slightly to moderately overgrown. Warm-water taxa, Discoaster, Sphenolithus, and Triquetrorhabdulus are abundant. We place the Oligocene/Miocene boundary (Cores 27A and 28A) within the Discoaster deflandrei Subzone of the Triquetrorhabdulus carinatus Zone.

Cores $29 \mathrm{~A}$ to $39 \mathrm{~A}$ are of Oligocene age. The highest three Oligocene zones are present in these cores: Sphenolithus ciperoensis Zone, Sphenolithus distentus Zone, and Sphenolithus predistentus Zone. Cyclicargolithus floridanus and sphenolith species dominate the assemblages. The continuation of the Oligocene section is found in Hole 366, which was continuously cored from Cores 5 to 53 ( 366 to $832 \mathrm{~m}$ ) through the Paleogene. The lowest sample of Hole $366 \mathrm{~A}(39 \mathrm{~A}, \mathrm{CC})$ is from the same stratigraphic level as sample $366-5, \mathrm{CC}$. In Hole 366 (Cores 6 to 10) Oligocene sediment from the Helicopontosphaera reticulata Zone and Sphenolithus predistentus Zone were recovered. Discoasters, which are the indicators for warm waters, are sparse or missing in the lower Oligocene in Cores 6 to 8 . Species present are Discoaster deflandrei, $D$. nodifer, and $D$. tanii.

Core 10, CC contains a late Eocene coccolith assemblage including Discoaster barbadiensis and Reticulofenestra reticulata. Discoasters outnumber chiasmoliths, which are absent from many samples in upper Eocene Cores 10 to 16. Only low-latitude zonation can be applied. Determination of coccoliths in Cores 14 to 18 is difficult because of moderate to thick overgrowth and fragmentation of specimens. This part of the Eocene belongs to the Reticulofenestra umbilica and Discoaster barbadiensis zones. The coccoliths are no better through the middle Eocene (Cores 18 to 32). Only Discoaster barbadiensis and D. strictus, among the discoasters, retain their identity in the limestone and chert lithology.

Discoasters are few or common in the lower Eocene (Cores 32 to 41 ). Eocene assemblages are very poorly preserved and not common. They show partial overgrowth and partial dissolution.

Our Paleocene/Eocene boundary is assumed between the Discoaster multiradiatus Zone and the Discoaster diastypus Zone which is represented in Cores 41 or 42 . Paleocene assemblages of coccoliths are found in Cores 42 to 53 . The following zones were identified: Discoaster multiradiatus Zone, Discoaster mohleri Zone, Heliolithus kleinpellii Zone, Fasciculithus tympaniformis Zone, and Cruciplacolithus tenuis Zone. The abundance of coccoliths is few to abundant, and preservation is moderate to poor.

It is possible that the section on Sierra Leone Rise is continuous from uppermost Cretaceous to Paleocene. However, a distance of about 20 meters exists between the lowest Paleocene $C$. tenuis Zone (Core 53) and the upper Maestrichtian L. quadratus Zone (Sample 55, CC).

\section{Mesozoic}

Rich assemblages of late Maestrichtian age coccoliths were identified in Sample 55, CC belonging to the Lithraphidites quadratus Zone.

\section{Radiolarians}

Radiolarians are common and well preserved only within two stratigraphic intervals cored at Site 366: the late Pleistocene and the middle Miocene to lower Eocene. Radiolarians are absent in all other samples examined. It is possible that some calcified radiolarian tests may be present in the Paleocene and lower Eocene sediments, but none have been identified by standard preparation procedures.

The following Cenozoic radiolarian zonal boundaries (see Johnson, this volume; Riedel and Sanfilippo, 1974) have been identified within the early Neogene and Paleogene sediments cored at Site 366.

The base of the Dorcadospyris alata Zone lies between 157 and 158 meters in Core 17A. The base of the Calocycletta costata Zone lies between 163 and 164 meters in Core 18A. The base of the Stichocorys wolffii Zone lies between the bottom of Core $20 \mathrm{~A}$ and the top of Core 21A. The base of the Stichocorys delmontensis Zone lies between the bottom of Core 25A and the top of Core 26A. The base of the Cyrtocapsella tetrapera Zone lies between 246 and 248 meters in Core 27A. The base of the Lychnocanoma elongata Zone lies between 270 and 277 meters in Cores $29 \AA$ and 30A. The base of the Dorcadospyris ateuchus Zone lies between 341 and 342 meters in Core 37A. The base of the Theocyrtis 
tuberosa Zone lies between 405 and 413.5 meters in Core 9. The base of the Theocyrtis tuberosa Zone lies between 489.5 and 499 meters between Sample 17, CC and Core 19, Section 1. The Podocyrtis goetheana Zone was identified only in Section 19-1. The base of the Podocyrtis chalara Zone lies between 519 and 520 meters in Core 21. The base of the Podocyrtis mitra Zone lies between 530 and 537 meters in Core 22. The base of the Podocyrtis ampla Zone lies between 540 and 546.5 meters in Core 23. The base of the Thyrosocyrtis triacantha Zone lies between 590 and 591 meters in Core 28. The base of the Theocampe mongolfier Zone lies between 601 and 603.5 meters in Core 29. The base of the Theocotyle cryptocephala cryptocephala Zone and Phormocyrtis striata striata Zone lies in the interval below 622.5 meters in Core 31. Radiolarians were very rare and poorly preserved in all samples examined from below this depth.

The absence of identifiable radiolarians in much of the upper Neogene section and in the Paleocene section is noteworthy, and may have significant paleooceanographic inplications. The Sierra Leone Rise evidently was not receiving significant siliceous skeletal material during a 15 m.y. interval from the middle Miocene until the late Pleistocene. Evidently the present locations of the zones of upwelling and high productivity in the equatorial Atlantic do not correspond with the positions of these zones during most of the late Neogene. A more precise documentation of this late Pleistocene shift in the circulation characteristics of the region will require a more extensive examination of the late Neogene depositional record over $a^{\circ}$ wide geographic region within the equatorial Atlantic, including Site 354, Leg 39, Ceará Rise, where similar observations were reported.

The absence of Radiolaria from the earliest Cenozoic sediments at this site may have a similar paleoclimatic explanation, or alternatively may be explained in terms of diagenetic effects. The increasingly poorer preservation of the radiolarian assemblages with depth in the Eocene sediments strongly suggests a diagenetic alteration of the siliceous skeletal material, perhaps to calcite. However, examination of the coarse fractions before acid treatment failed to reveal identifiable calcified radiolarian tests, suggesting that perhaps siliceous sedimentation did not occur in the region during the earliest Cenozoic. An additional possibility is that silica was indeed deposited during the early Paleogene, but that diagenetic effects caused vertical migration of the silica and redeposition as chert in the overlying middle and late Eocene sediments. The resolution of the questions of silica accumulation during the early Cenozoic requires a more detailed examination of the cherts and of the coarse fraction within the early Cenozoic material.

\section{Summary}

Several additional preliminary observations can be made concerning the biostratigraphic succession recovered at Site 366 :

1) The abundance and the degree of preservation of the different micfofossil groups vary considerably within the sampled interval. Diagenesis, dissolution, and variations in primary productivity all appear to be controlling factors in producing the variations observed. For example, the absence of Radiolaria from the middle Miocene to upper Pleistocene sediments is almost certainly indicative of substantial geographic migrations in the location and/or the intensity of upwelling in the eastern equatorial Atlantic. The increasingly poorer preservation of nannofossil assemblages with increasing age between the middle Miocene and Paleocene is probably a consequence of diagenetic overgrowths of calcite on the nannofossil specimens. The impoverished and poorly preserved foraminiferal faunas of the middle Eocene through lower Oligocene is perhaps a result of selective dissolution. All of these factors (diagenesis, dissolution, productivity) and perhaps others have played a major role in controlling the rates and types of sediments supplied to the sea floor and the effects of postdepositional alterations which we can observe.

2) Assemblages of all microfossil groups are remarkably free of contamination by reworking. None of the samples examined yielded evidence of vertical mixing or lateral redeposition. Particle-by-particle deposition of pelagic skeletal debris has been the dominant sedimentation process on this portion of the Sierra Leone Rise during the entire Cenozoic.

3) All microfossil groups represent tropical to subtropical assemblages for the entire Cenozoic. There is no evidence for any intrusions of extra-tropical water masses for significant periods of time during the Tertiary.

4) The water depth at Site 366 did not change substantially during the Cenozoic. The character of the benthic foraminiferal assemblages and the relative proportion of benthic to planktonic foraminifers requires that the site remained at intermediate depths $(>2000 \mathrm{~m})$ for most of the Cenozoic. However, the benthic foraminifers from the uppermost Cretaceous assemblages suggest that the water depth over the Sierra Leone Rise may have been somewhat shallower during the pre-Cenozoic.

\section{ACCUMULATION RATES}

The zonation of core-catcher material by the different planktonic organisms leads to similar trends in accumulation rate over a large time interval, although there are some differences between the absolute ages estimated for the different microfossil assemblages within individual core-catcher samples. Age assignment by nannofossils have been correlated to the Cenozoic time scale after Martini (1976); planktonic foraminifer zones have been assigned absolute ages following the zonation schemes of Berggren (1971), Blow (1969), and Saunders et al. (1973); and radiolarian zones have been correlated to the principal epoch boundaries according to the revised Cenozoic zonation of Riedel and Sanfilippo (1974). The data from the individual microfossil groups have been combined in Figure 12 to yield an approximate accumulation rate curve. The accumulation rates are not corrected for compaction. 


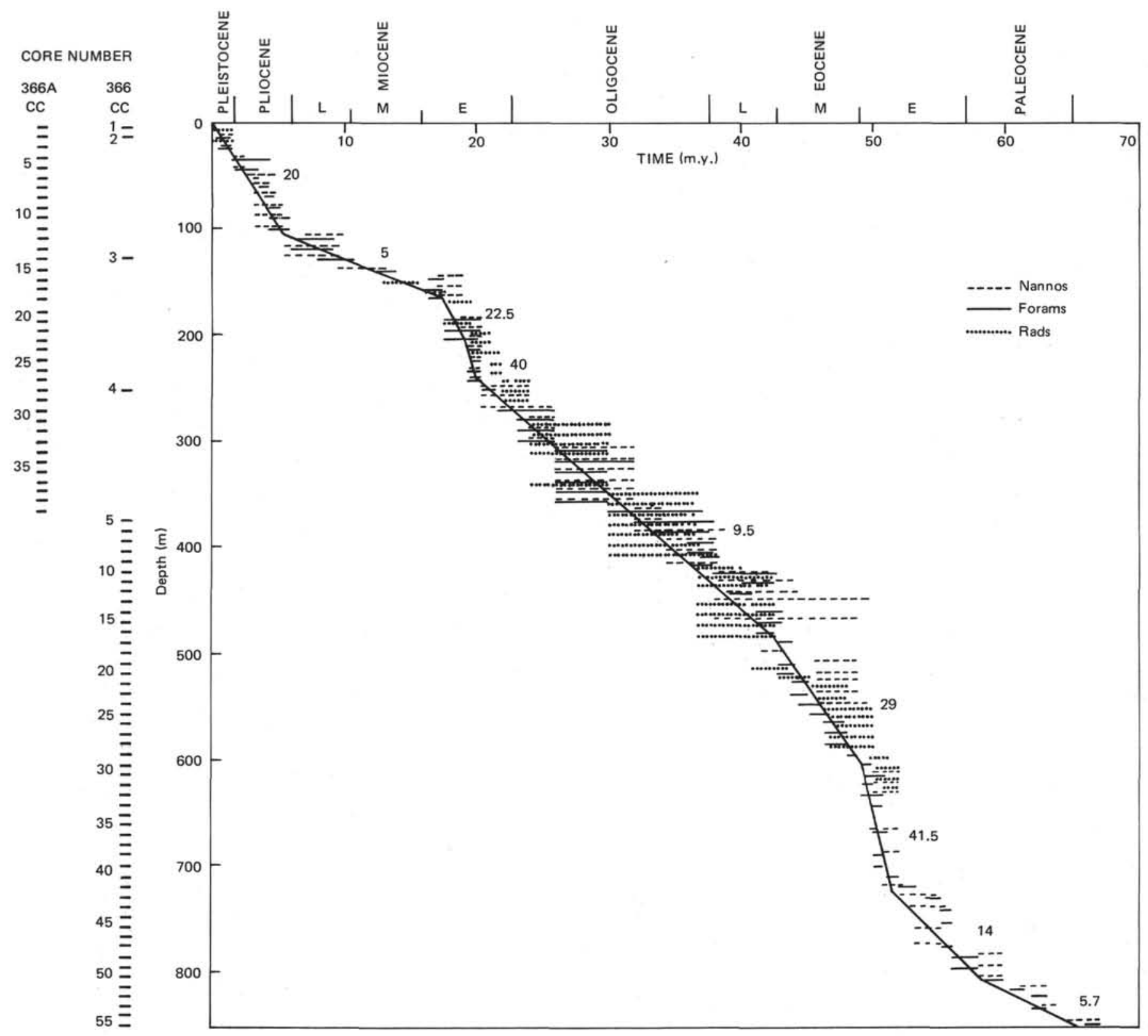

Figure 12. Average accumulation rate curve (in $\mathrm{m} / \mathrm{m} . \mathrm{y}$.) for Site 366. The accumulation rates have not taken compaction into account.

The average Cenozoic accumulation rate is about 12 $\mathrm{m} / \mathrm{m} . \mathrm{y}$. This rate is consistent with the continuously isolated position of Site 366 influenced primarily by pelagic deposition.

Six principal intervals can be distinguished on the accumulation rate curve obtained, disregarding the effects of compaction and dissolution. The Pleistocene/Pliocene time interval shows rates of about 20 $\mathrm{m} / \mathrm{m} . \mathrm{y}$. The late and middle Miocene rate is about 5 $\mathrm{m} / \mathrm{m} . \mathrm{y}$. There are quite constant deposition rates of about $10 \mathrm{~m} / \mathrm{m}$.y. from the early Miocene to the top of the middle Eocene, with an increased rate to $29 \mathrm{~m} / \mathrm{m}$.y. Rates of accumulation during the lower part of the lower Eocene are about twice as high $(41.5 \mathrm{~m} / \mathrm{m} . \mathrm{y}$.) as in the overlying interval. The lower part of the early Eocene and the Paleocene show normal rates of 5 to 15 $\mathrm{m} / \mathrm{m} . \mathrm{y}$.

\section{CORRELATION OF REFLECTION PROFILE WITH DRILLING RESULTS}

The seismic reflection profiles recorded while approaching and leaving Site 366 (see Figure 5) show the acoustic section at the site to consist of a set of parallel reflectors. The correlation of the drilling results with these reflectors is based mainly on the record obtained while leaving the site at slow speed. Comparison with Lamont-Doherty seismic profiles recorded on the rise show that the reflectors observed on Glomar Challenger profiles are clearly of regional extension and significance.

The uppermost reflector observed at $0.26 \mathrm{sec}$ below the sea floor is relatively faint. It probably corresponds with the younger stage of lithification of the calcareous sediments, as at several other DSDP sites located on 
carbonate-covered oceanic rises. At this site, however, drilling disturbances encountered in the soft chalk make the transition between ooze and chalk appear rather gradational. Therefore, no definite correlation between the lithology and the acoustic section can be established for this reflector, and no estimate of the interval sound velocity could be obtained for this uppermost part of the section. If a range of values of 1.60 to $1.70 \mathrm{~km} / \mathrm{sec}$ (Figure 11) is considered probable for this interval, then the first reflector should correspond to layers situated at 210 to 225 meters below the sea floor.

A highly reflective horizon or set of closely spaced reflective horizons is observed at about $0.5 \mathrm{sec}$. Only the top of this reflective zone can be significantly correlated with drilling results because of intense reverberation within this horizon, probably resulting from multiple internal reflections. The top of this zone correlates quite well with the first (younger) occurrence of hard porcellanite layers appearing in the sedimentary column at about 480 meters subbottom. A definite decrease in the drilling rate is also recorded at that depth. Below that level, porcellanite and chert (below $508 \mathrm{~m}$ for the chert) are quite common down to about 680 meters. This correlation gives an estimate of 1.82 $\mathrm{km} / \mathrm{sec}$ for the interval sound velocity of the layer between the sea floor and the first silicified layers. This value compares well with the velocities measured on core samples, and with interval velocities obtained from sonobuoys by Hoskins et al. (1974) on Sierra Leone Rise about $80 \mathrm{~km}$ southwest of Site 366 .

Below the strong reflector, the seismic profile shows the presence of two lower ones. The uppermost of these lies at about $0.78 \mathrm{sec}$ below the sea floor and the lowermost one is at $0.9 \mathrm{sec}$. The sedimentary layers corresponding with the latter were not reached at Site 366 . The correlation between the reflector at $0.78 \mathrm{sec}$ and a lithological change in the sedimentary column is questionable. A break in the drilling rate observed at about 740 meters subbottom does not seem to correspond with any marked change in the lithology. Moreover, a correlation between this drilling break and the reflector is unlikely because it would result in an unreasonably low interval velocity $(2.0 \mathrm{~km} / \mathrm{sec}$ for the limestone, siliceous limestone, and chert recovered between 480 and $740 \mathrm{~m}$ ). An important change from limestone grading downward to marl is recorded at about 775 meters subbottom. This marl corresponds to a zone with a noticeable increase in the drilling rate.

A correlation between the reflector at $0.78 \mathrm{sec}$ and the top of the marl gives an interval velocity of 2.11 $\mathrm{km} / \mathrm{sec}$, a rather low value, for the overlying lithologies. It is possible that the layers corresponding to that reflector were not sampled in Hole 366 because they lie at depths greater than total penetration $(850.5$ $\mathrm{m})$. However, if the reflector corresponds with sedimentary layers from anywhere below the total depth, the sound velocity for the interval between that depth and the reflector at $0.5 \mathrm{sec}$ would be greater than $2.65 \mathrm{~km} / \mathrm{sec}$. This value seems slightly too high, considering the relatively low proportion of chert versus marl and chalk in that part of the section.
No indication about the nature of the lowermost reflector was obtained, because drilling terminated above them.

Figure 13 is a schematic interpretation of these results.

\section{SUMMARY AND CONCLUSIONS}

Figure 14 is a summary of the coring, lithology, biostratigraphy, and drilling rates at Site 366 . The site was drilled in the upper part of the Sierra Leone Rise in a region where the seismic reflection profiles suggest the sedimentary section may be complete and undisturbed. The water depth of 2860 meters, well above the present level of the CCD, was a determining factor in the accumulation of a thick, relatively well preserved, and complete carbonate section. The Mesozoic part of the sedimentary record could not be sampled because of technical difficulties, but the almost complete Cenozoic section recovered makes the results of this site particularly interesting. The section was continuously cored from the sea floor to a subbottom depth of 850.5 meters. 582 meters of sediment, representing $68 \%$ of the drilled interval, were recovered. This overall recovery is close to the average recovery per core so, except for some cherty and porcellanitic horizons in the middle part of the section and for the lowermost 38 meters, the samples recovered can be considered representative of the entire section.

\section{Most Significant Results}

A nearly complete section of the Cenozoic was obtained. It represents a typical pelagic record for an oceanic rise and can be compared with the record obtained on similar elevated oceanic areas in the western Atlantic (Ceará Rise, in particular), and in the South Atlantic (Walvis Ridge and Rio Grande Rise), as well as in the Pacific (Shatsky, Hess, Magellan Rise, and Manihiki Plateau). This network of biostratigraphic reference sections covers different latitudes as well as different basins. The Sierra Leone Rise record appears to provide an ideal reference section for the low-latitude Atlantic Cenozoic record. Two characteristics make this record particularly useful:

1) the section is nearly complete and only very minor stratigraphic hiatuses are present; and

2) the presence of abundant planktonic foraminifers, nannoflora, radiolarians, and, to some extent diatoms, provides an excellent opportunity to correlate zonal boundaries obtained from these different microfossil groups in the tropical-subtropical environment.

Another aspect of the results obtained at this site is the very good opportunity to study the mode of deposition and diagenetic alterations of open marine deep-water carbonate facies. The relative importance of sediment input versus diagenesis can be studied in detail at this site because of generally constant and relatively high rates of accumulation. Also, of particular interest is the occurrence of cyclic sedimentation where the respective roles of dissolution and dilution can be estimated. 


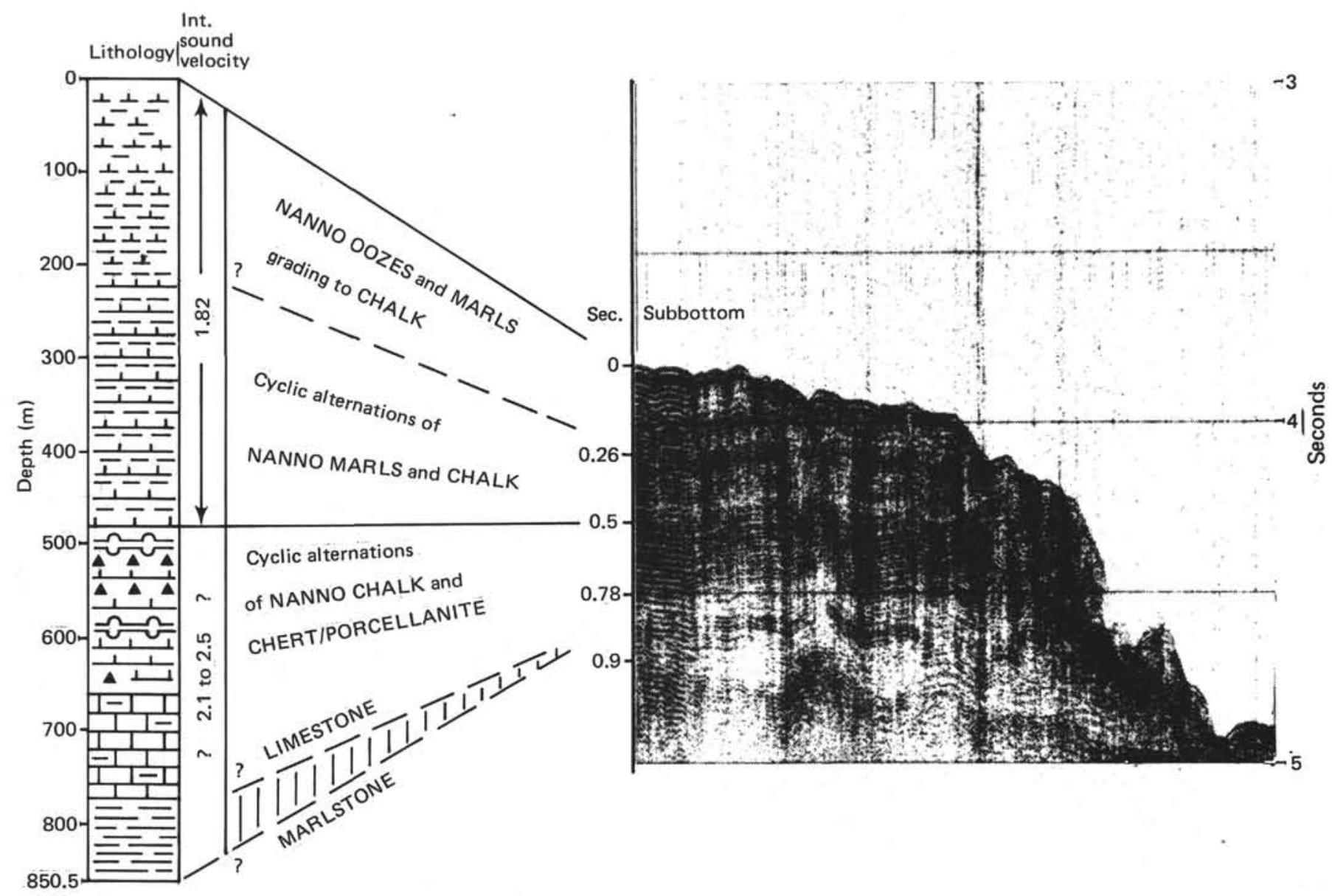

Figure 13. Correlation of seismic profile and drilling results at Site 366.

\section{Nature of the Sediments}

The section sampled consists of predominantly calcareous pelagic facies with carbonate values ranging from about $40 \%$ to $80 \%$. The sediments are nannofossil ooze and marly ooze with common foraminifers, grading downward to chalk and marl, and then to limestone and marlstone. The middle to lower Eocene sediments show classical occurrences of silicified sediments in the form of interbedded porcellanite and chert. Most of the chalk, marl, and limestone show evidence of cyclic bedding with alternations of clay-rich and clay-poor calcareous beds. The average porosity of the sediment shows a general decrease toward greater depth from about $70 \%$ to $25 \%$. The color varies within shades of brownish, grayish, and greenish gray with light greenish gray being largely dominant. Organic carbon content is always very low and averages about $0.1 \%$.

\section{Stratigraphy}

Apart from minor hiatuses near the upper and lower boundaries of the middle Miocene, the Cenozoic record was completely sampled. In the lowermost part, however, near the Cretaceous/Tertiary boundary the lowermost zone of the Danian stage as well as the uppermost zone of the Maestrichtian stage were not recovered. However, the fact that these missing zones correspond to a sampling gap of about 38 meters, strongly suggests the absence of any hiatus at the Cretaceous/Tertiary boundary. Radiolarians are absent in upper Miocene, Pliocene, and early Pleistocene sediments, but below the lower Eocene they rapidly disappear. If the absence of radiolarians in the upper Miocene and the Pliocene sediments seems to correspond to a lack of radiolarians in the overlying waters at these times, then the relative influence of low input versus diagenetic dissolution in the lower part of the section is not clearly defined. Diatoms, usually well preserved, are present in many intervals (see Schrader, this volume). The complete absence of Braarudosphaera among the Oligocene nannofossils is noteworthy because it has been reported as abundant in the South Atlantic. This contrast provides a control over the lateral northern extension of the Braadrudosphaera chalks.

\section{Paleoenvironment}

The entire Cenozoic section was deposited in relatively deep water. Benthic assemblages and benthic/planktonic foraminifer ratios in the uppermost Cretaceous sediment, however, suggests a slightly shallower environment at that time. In any case, the sea floor on Sierra Leone Rise has always remained above the level of the CCD since at least the latest Cretaceous.

Bottom circulation is believed to have remained permanent during the entire Cenozoic, keeping the sediment-water interface always well oxygenated. 
SITE 366: SIERRA LEONE RISE

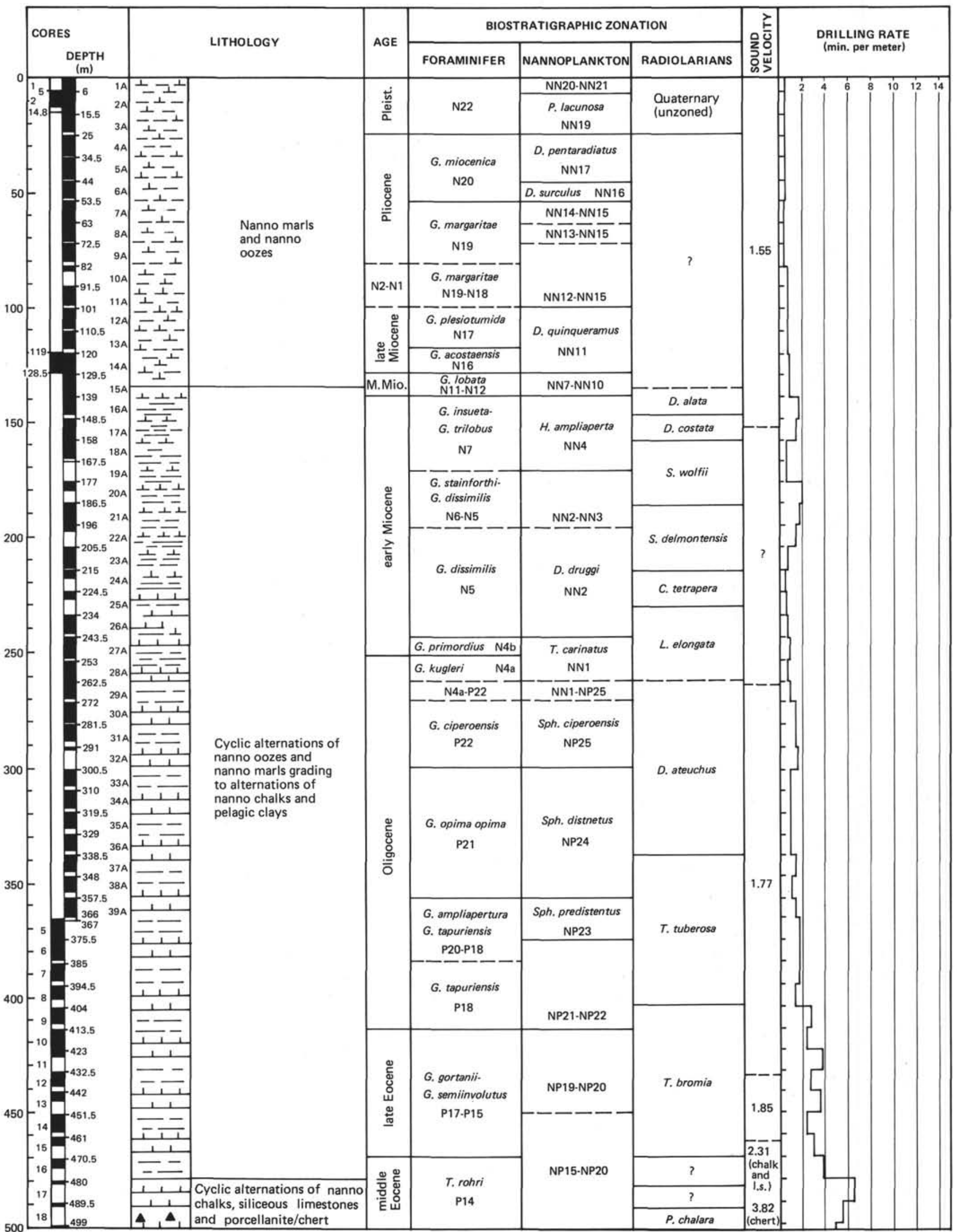

Figure 14. Summary of coring, lithology, biostratigraphy, and drilling rate at Site 366. 


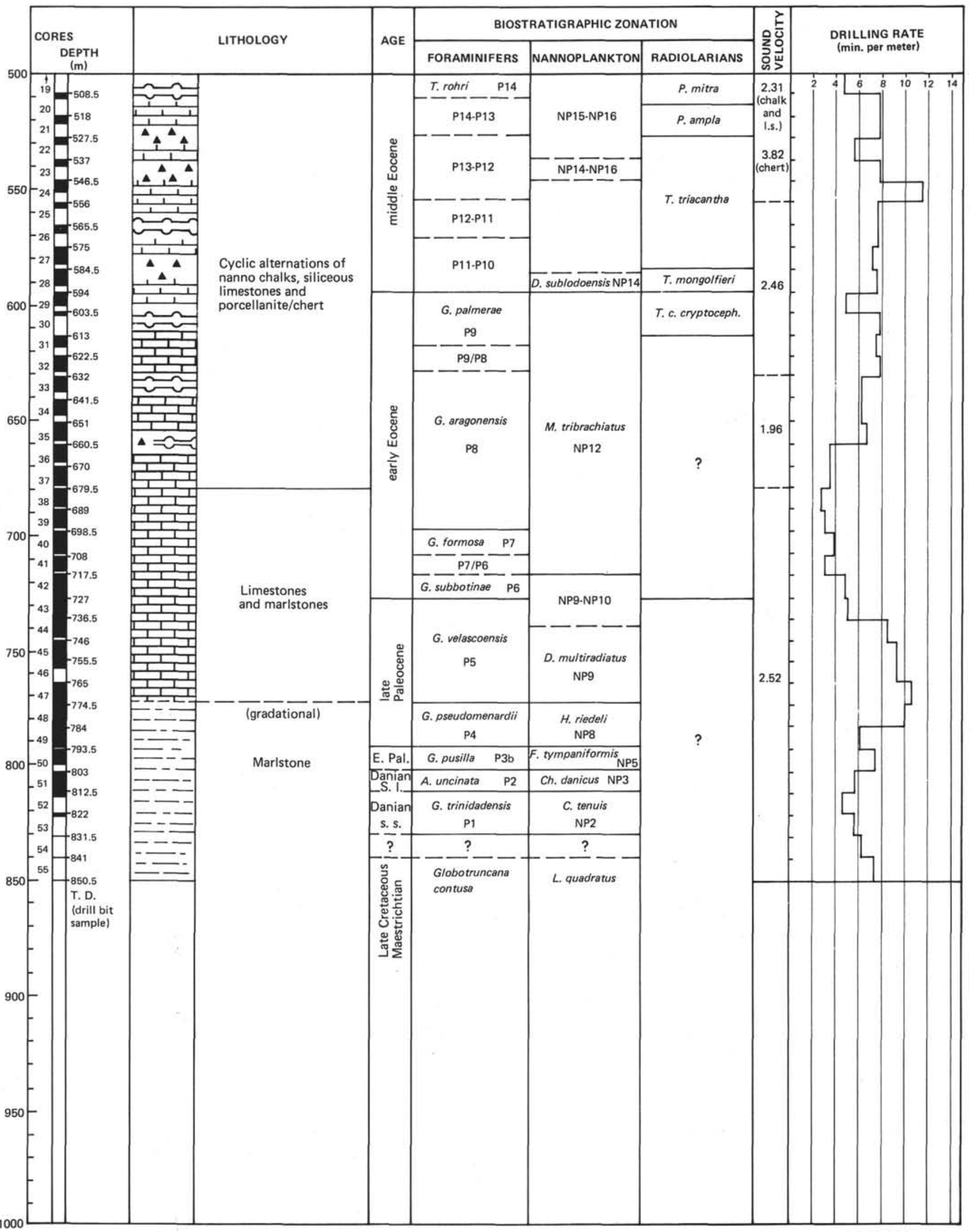

Figure 14. (Continued). 
Bottom currents, however, were never strong enough to produce significant removal or non-deposition of sediments. The oxygenation of the bottom is attested to by the great abundance of burrows, thus the occasional occurrence of pyrite is believed to be related to reducing microenvironments within the sediment. The circulation during the early Eocene might have been slightly more vigorous, because lenses and thin layers rich in foraminifers indicate winnowing. Apparently the only period of very active bottom circulation has been relatively recent, suggested by evidence of erosion from both PDR and seismic reflection profiles (Figures 5, 6B, 6C).

The productivity of the surface waters probably always remained relatively high. The distribution of radiolarians, however, suggests a reduction in the productivity during the early Pleistocene-Pliocene and the upper Miocene, as well as before the middle Eocene.

The rate of accumulation is controlled primarily by productivity in the surface waters and dissolution on the bottom because terrigenous input is only of minor importance. Excellent stratigraphic control provides a very detailed rate of accumulation curve (Figure 12). The average value of $12 \mathrm{~m} / \mathrm{m} . \mathrm{y}$. for the entire Cenozoic compares well with other oceanic rises. Maxima occur in the early Eocene $(41.5 \mathrm{~m} / \mathrm{m} . \mathrm{y}$.$) and in the early$ Miocene $(40 \mathrm{~m} / \mathrm{m} . \mathrm{y}$.) and minimum occurs during the middle to late Miocene. Similar trends have been observed on the Ceará Rise during Leg 39 (Site 354). There appears to be a very good correlation between the minima observed in the rate of accumulation curve on the Sierra Leone Rise (this site) and the occurrence of hiatuses in the deep basins, particularly in the South Atlantic (as well as on Ceará Rise in the southwestern North Atlantic). This observation compares well with similar trends observed in the western Pacific during Leg 32 (Lancelot and Larson, 1975) where the large hiatus observed at the Cretaceous/Tertiary boundary in the basin corresponds to shorter hiatuses or mere drops in the rate of accumulation on rises. If drops in productivity of the surface waters were responsible for these hiatuses, then the role of bottom circulation in producing hiatuses or slow deposition, even on the rises, could be overestimated. However, PDR and seismic reflection profiles on top of Sierra Leone Rise clearly show recent erosion.

The cyclic sedimentation observed in the lower to middle Eocene and in the upper Eocene to middle Miocene sediments (see Dean et al., this volume) poses interesting problems. Bedding in the lower to middle Eocene sediments is mainly an alternation of cherty or porcellanitic layers with nannofossil chalk, and it is not clear whether this is due in part or totally to differences in the original silica content of these different beds, or if the original physical properties such as porosity and permeability (possibly related to the composition also) have played a major role in producing a selective silica recrystallization. Apparently "chertification" seems to have been favored by the most permeable environments. This seems logical if one considers the necessity for migration and concentration of relatively large amounts of silica in the pore waters in order to precipitate chert layers or nodules. The cyclic bedding observed in upper Eocene, Oligocene, lower Miocene, and lowermost middle Miocene sediments is of a different nature. It closely resembles the widespread limestone/marl sequences well known in many geological formations on land. The cycles represent variations in the relative amounts of terrigenous and biogenous components being delivered to the sea floor. The marly layers might only reflect dilution by increased amounts of clay minerals, or they might also reflect dissolution cycles (Dean et al., this volume). The purely pelagic nature of the cycles suggests influence of climatic variations because Sierra Leone Rise is clearly separated from the African margin and because it is standing well above the level of the adjacent basins.

\section{REFERENCES}

Berggren, W. A., 1971. Tertiary boundaries and correlations. In Funnell, B. M. and Riedel, W. R. (Eds.), The. micropaleontology of oceans: Cambridge (Cambridge University Press), p. 693-809.

Blow, W. H., 1969. Late middle Eocene to Recent planktonic foraminiferal biostratigraphy: 1st Internatl. Conf. Plankt. Microfossils, Proc., Geneva, v. 1, p. 199-422.

Bullard, E., Everett, J. E., and Smith A. G., 1965. The fit of the continents around the Atlantic, a symposium on continental drift: Phil. Trans. Roy. Soc. London, Ser. A, v. 258 , p. 41 .

Hayes, D. E., Pimm, A. C., et al., 1972. Initial Reports of the Deep Sea Drilling Project, Volume 14: Washington (U.S. Government Printing Office).

Hayes, D. E. and Rabinowitz, P. D., 1975. Mesozoic magnetic lineations and the magnetic quiet zone off northwest Africa: Earth Planet. Sci. Lett., v. 28, p. 105-115.

Hoskins, H., Rogers, C. U., and Woo, A. O., 1974. Data report of oblique reflection-refraction radio-sonobuoy profiles on the African Atlantic continental margin (R/V ATLANTIS II, Cruise 67 and 75): IDOE-WHOI Tech. Rept., unpublished manuscript.

Jacobi, R. and Hayes, D. E., in preparation. Bathymetry and microphysiography of the continental margin off northwest Africa.

Lancelot, Y. and Larson, R. L., 1975. Sedimentary and tectonic evolution of the northwestern Pacific. In Larson, R. L., Moberly, R., et al., Initial Reports of the Deep Sea Drilling Project, Volume 32: Washington (U.S. Government Printing Office), p. 925-939.

Marshall, C. M., 1975. Summary of physical propertiesLeg 32. In Larson, R. L., Moberly, R., et al., Initial Reports of the Deep Sea Drilling Project, Volume 32: Washington (U.S. Government Printing Office), p. 961962.

Martini, E., 1976. Cretaceous to Recent calcareous nannoplankton from the central Pacific Ocean (DSDP Leg 33). In Schlanger, S. O., Jackson, E. D., et al., Initial Reports of the Deep Sea Drilling Project, Volume 33; Washington (U.S. Government Printing Office), p. 383-423.

Maxwell, A. E., et al., 1970. Initial Reports of the Deep Sea Drilling Project, Volume 3: Washington (U.S. Government Printing Office).

Riedel, W. R. and Sanfilippo, A., 1974. Stratigraphy and evolution of tropical Cenozoic radiolarians: Ms. prep. for 3rd Plankt. Conf., Kiel, 1974.

Saunders, J. B., Beaudry, F. M., Bolli, H. M., Hay, W. W., Premoli Silva, I., Riedel, W. R., Rogl, F., Sanfilippo, A., 
1973. Paleocene to Recent microfossil distribution in the marine and land areas of the Caribbean. In Edgar, N. T., Saunders, J. B., et al., Initial Reports of the Deep Sea Drilling Project, Volume 15: Washington (U.S. Government Printing Office), p. 769-771.
Schlanger, S. O., Jackson, E. D., et al., 1976. Initial Reports of the Deep Sea Drilling Project, Volume 33: Washington (U.S. Government Printing Office).

Uchupi, E., 1971. Bathymetric atlas of the Atlantic, Caribbean, and Gulf of Mexico, WHOI. 


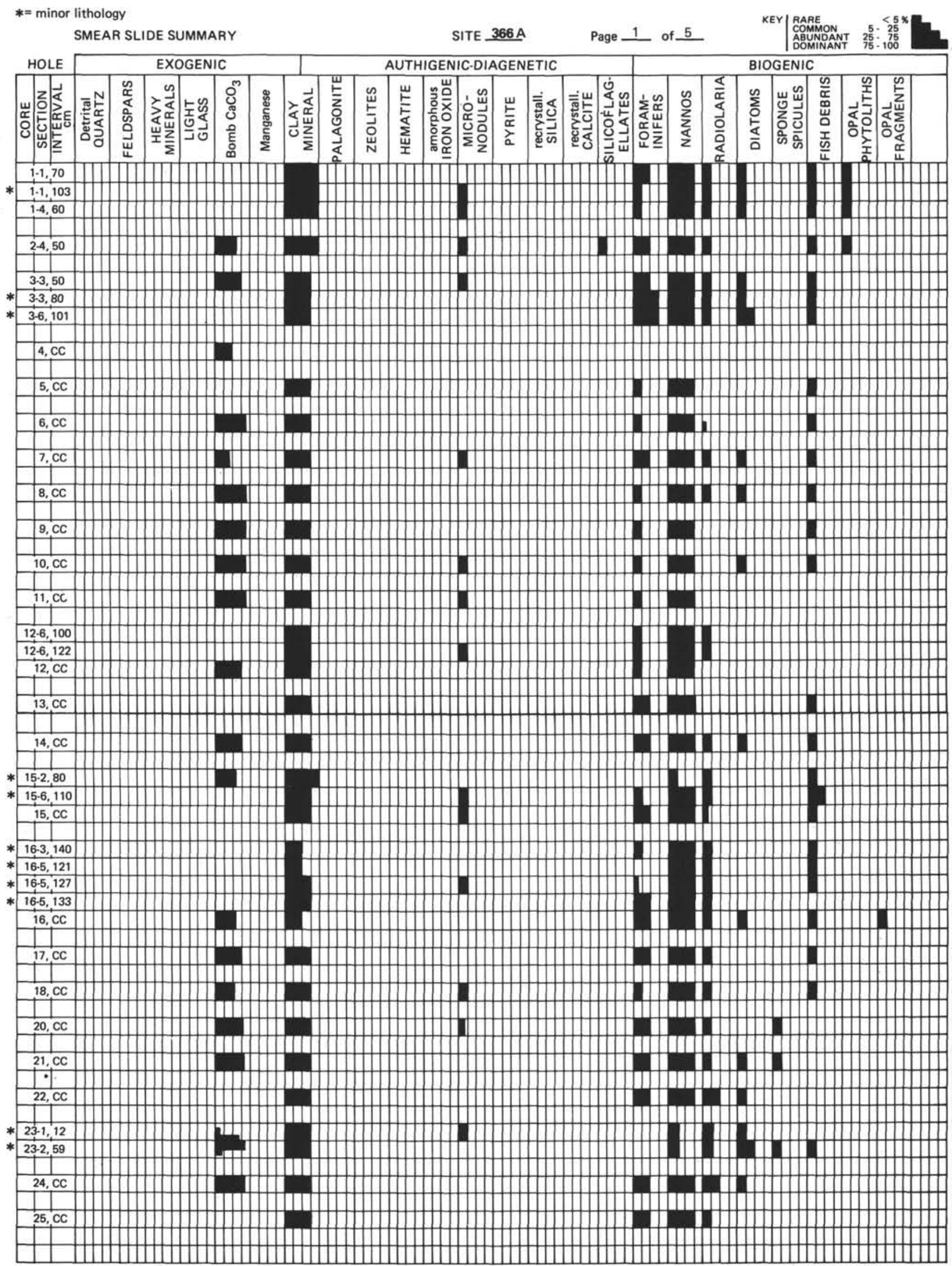


SITE 366: SIERRA LEONE RISE

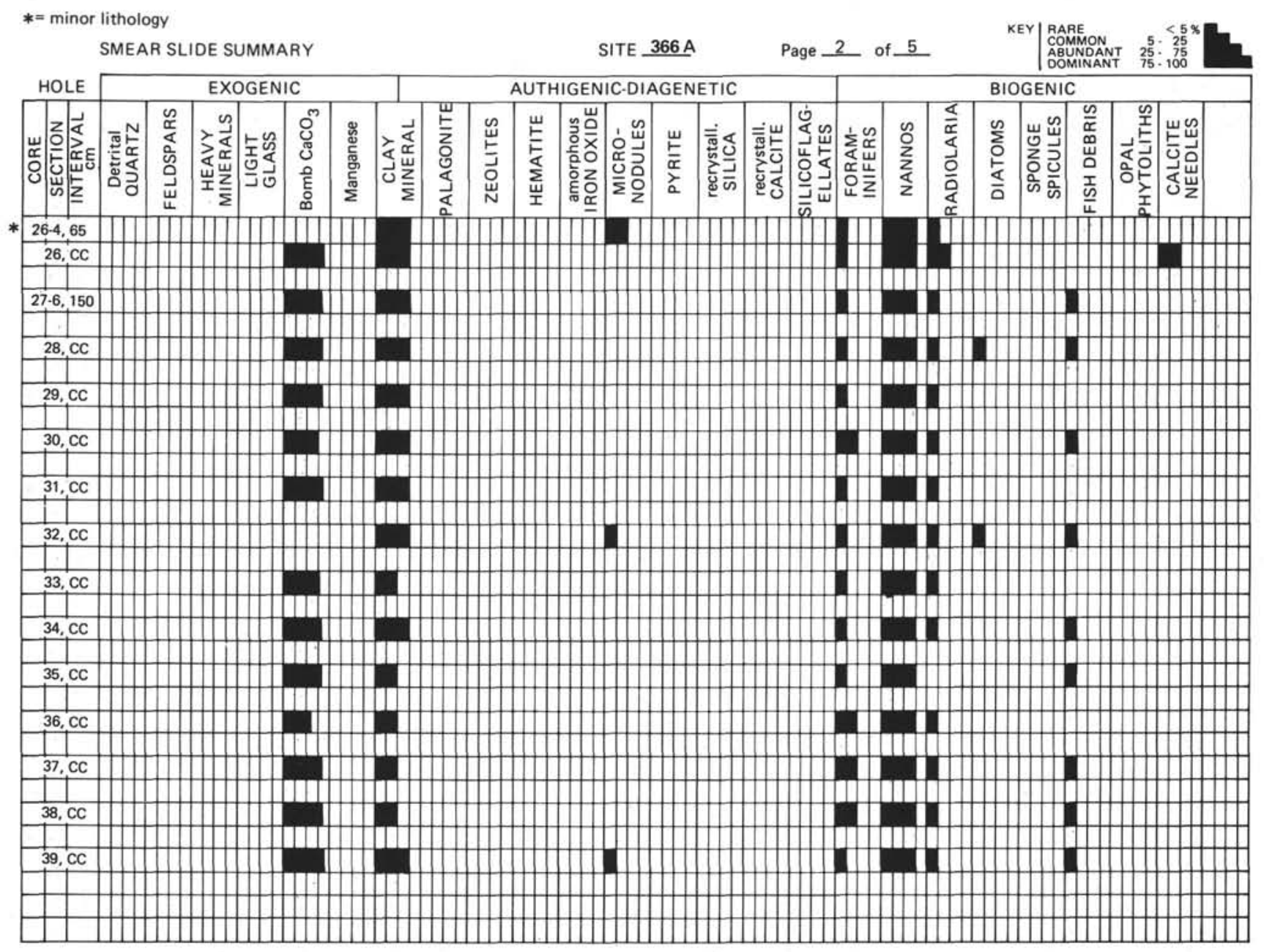




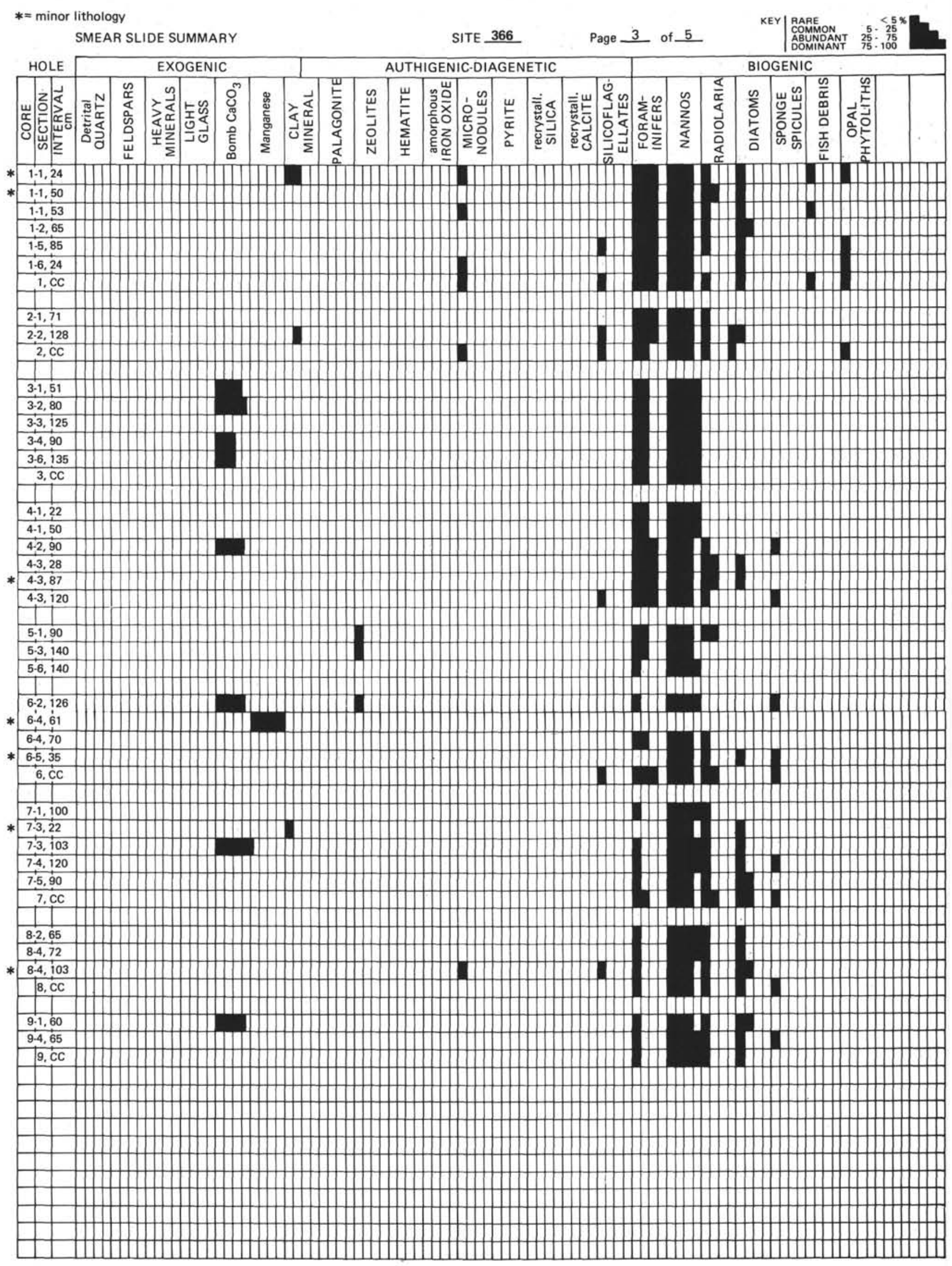




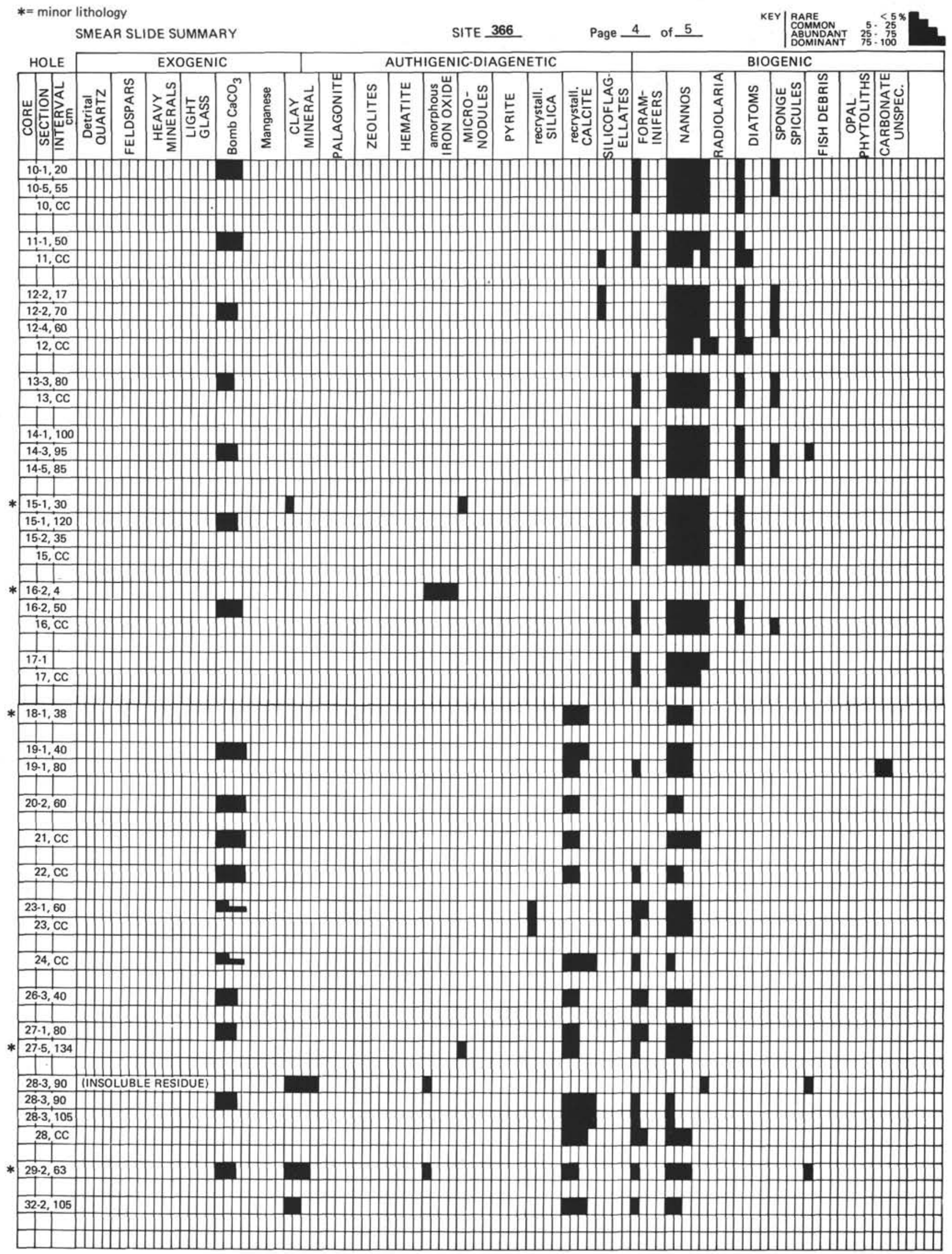




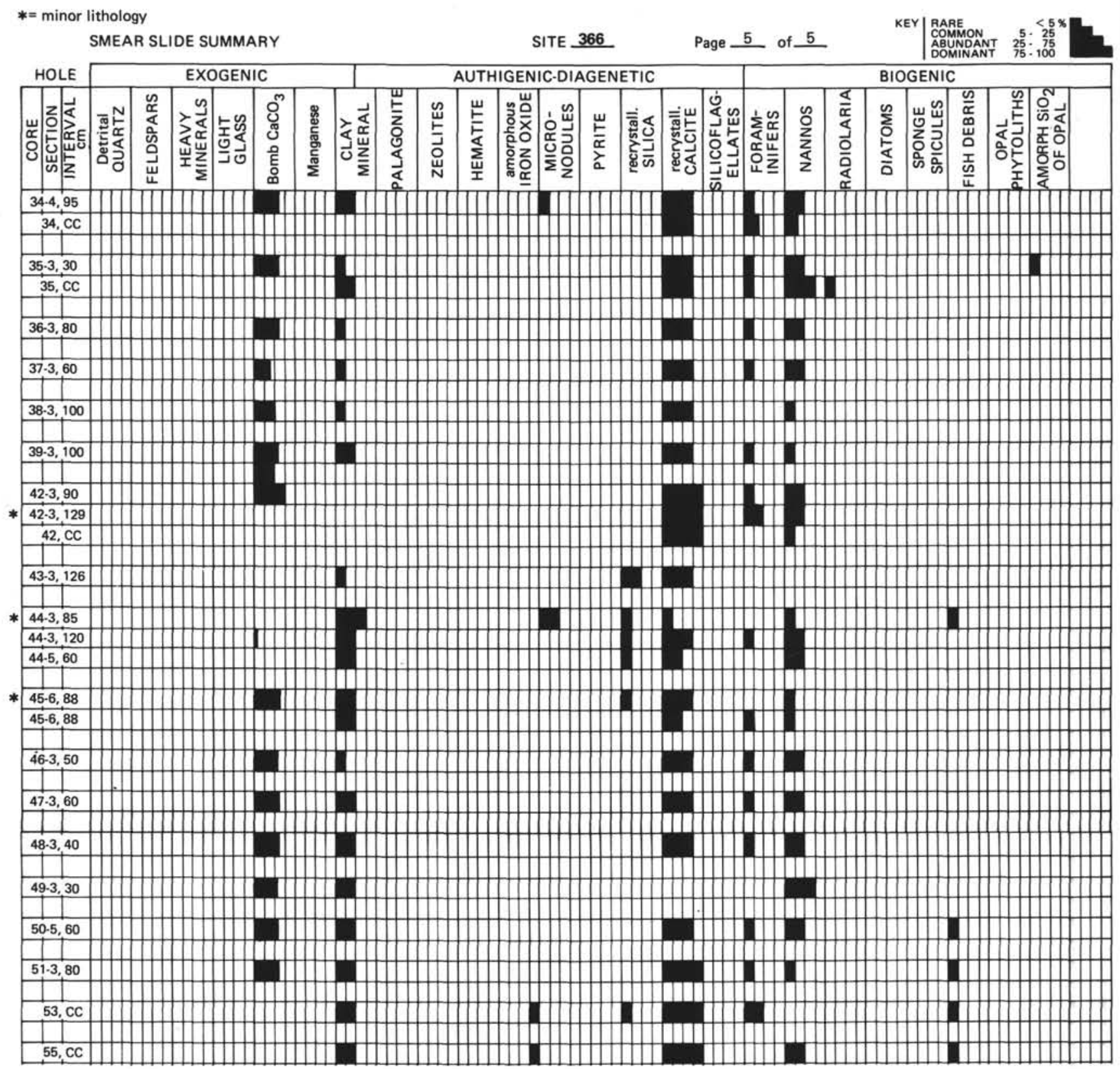




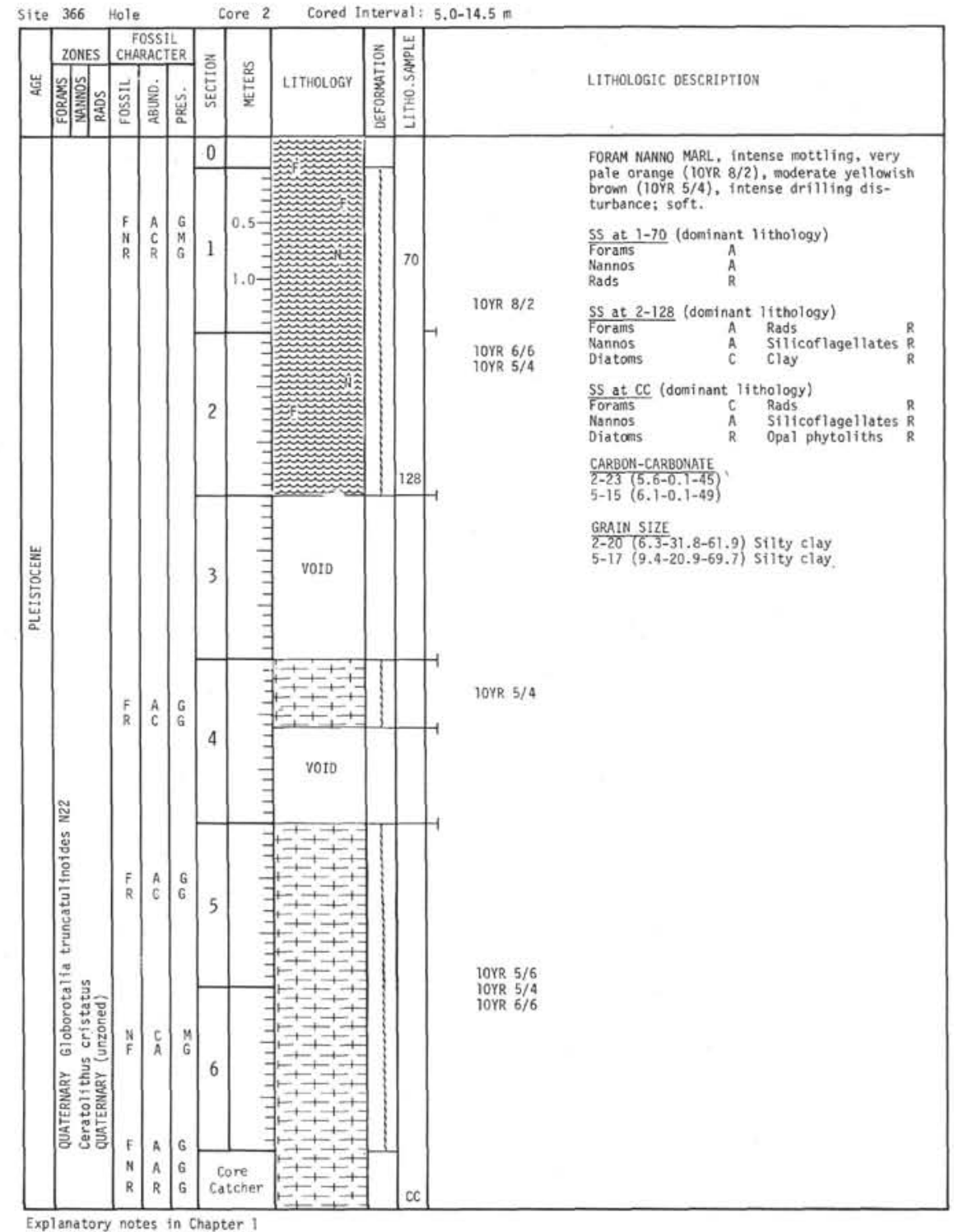




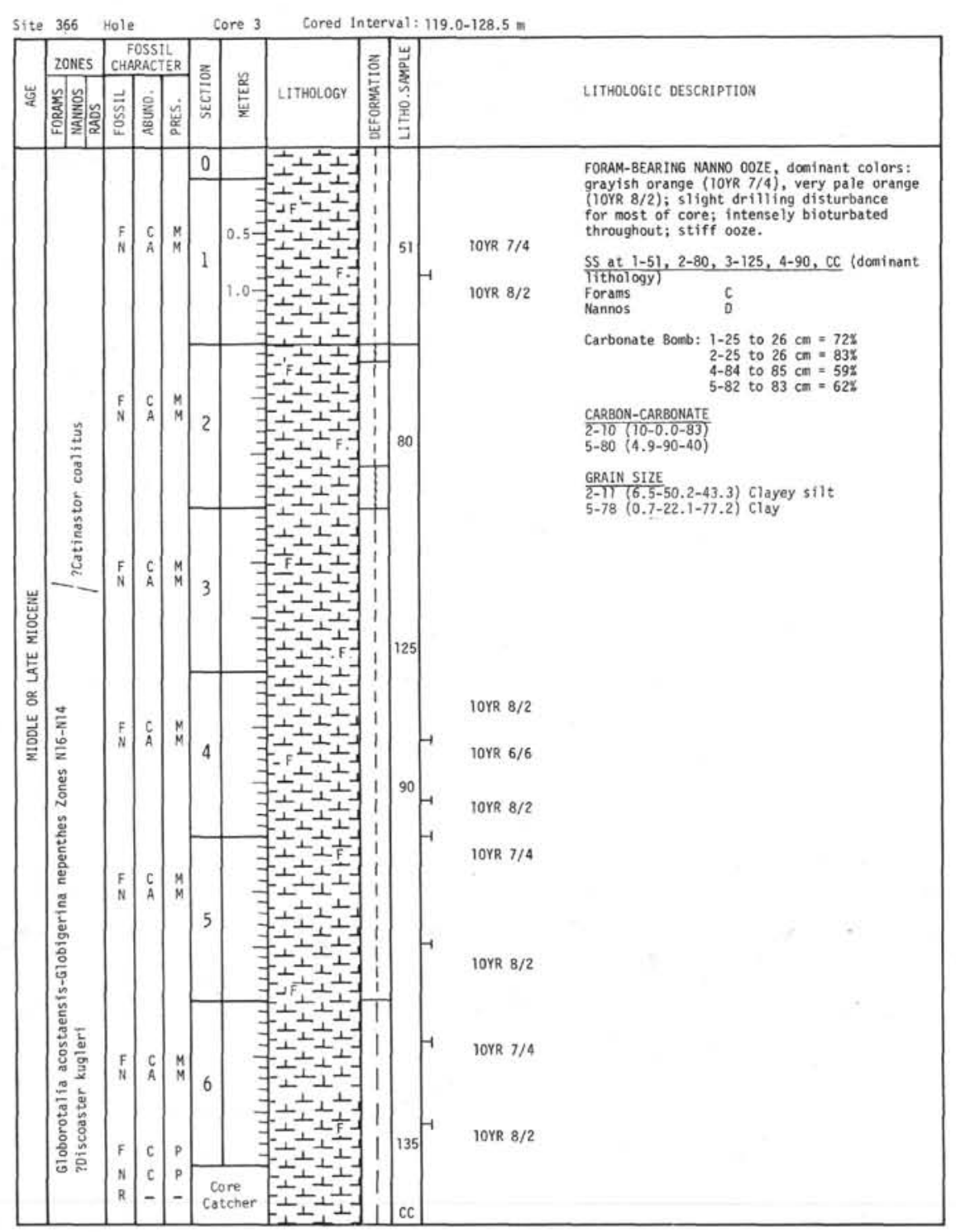

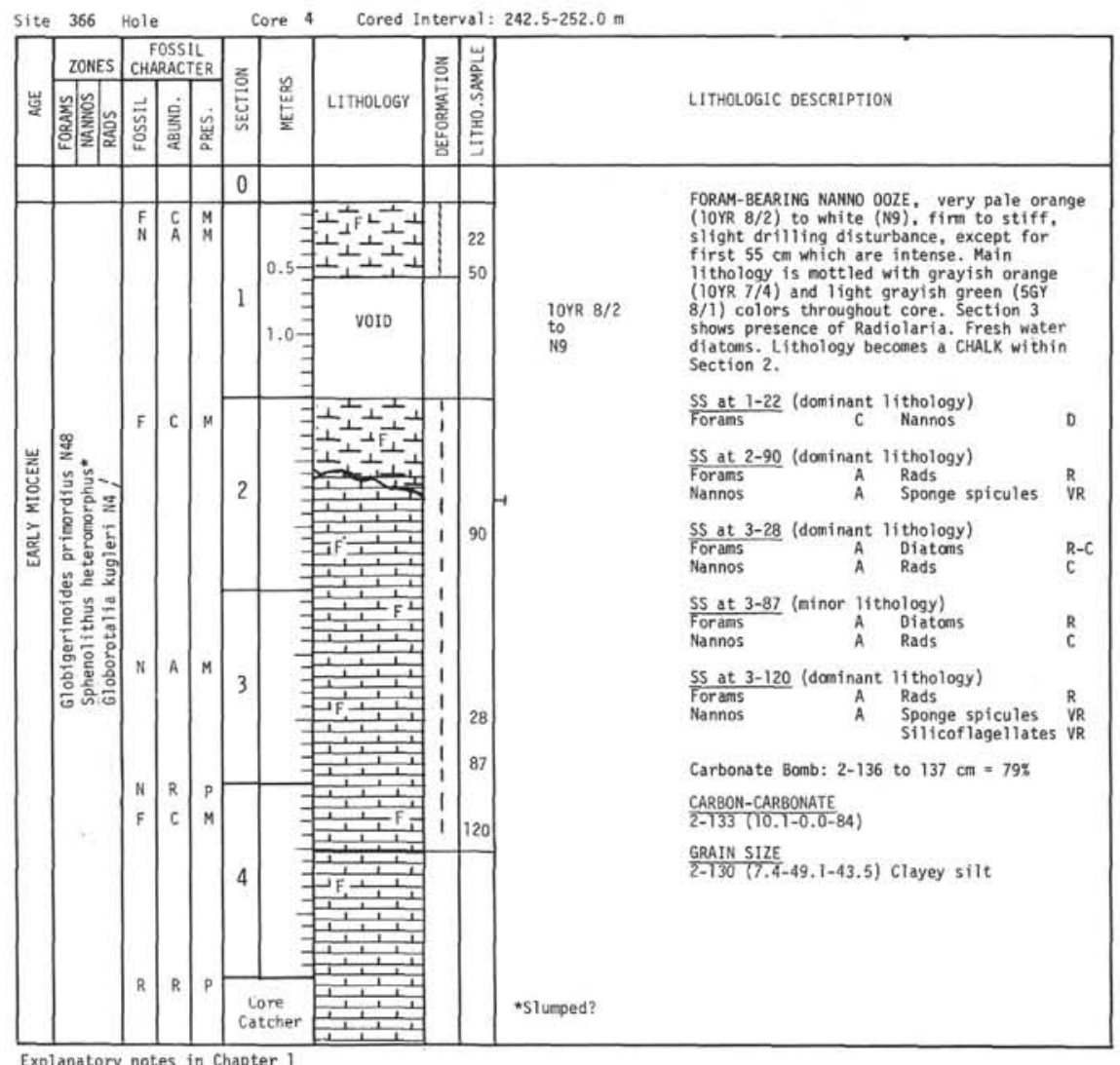




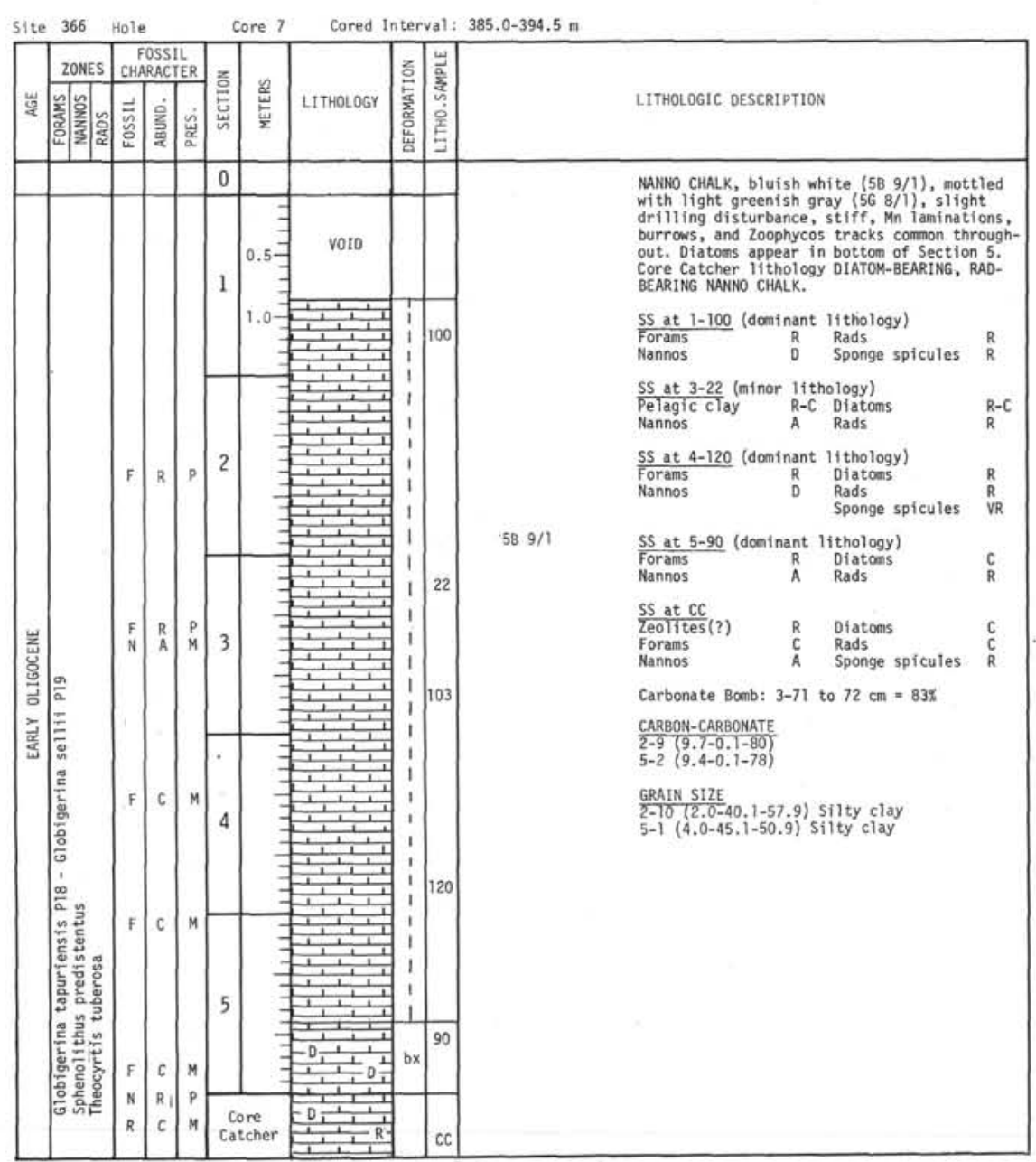

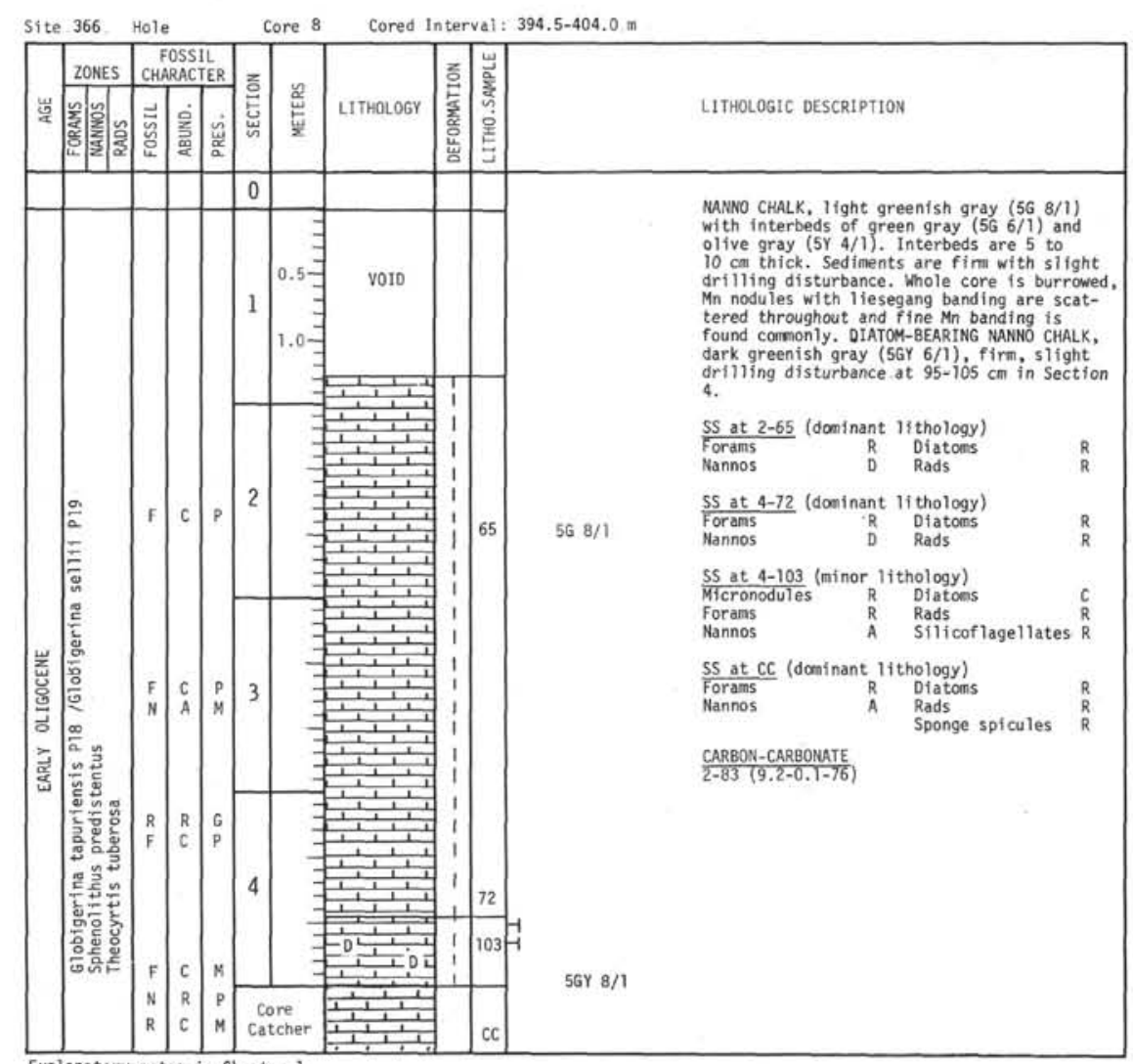




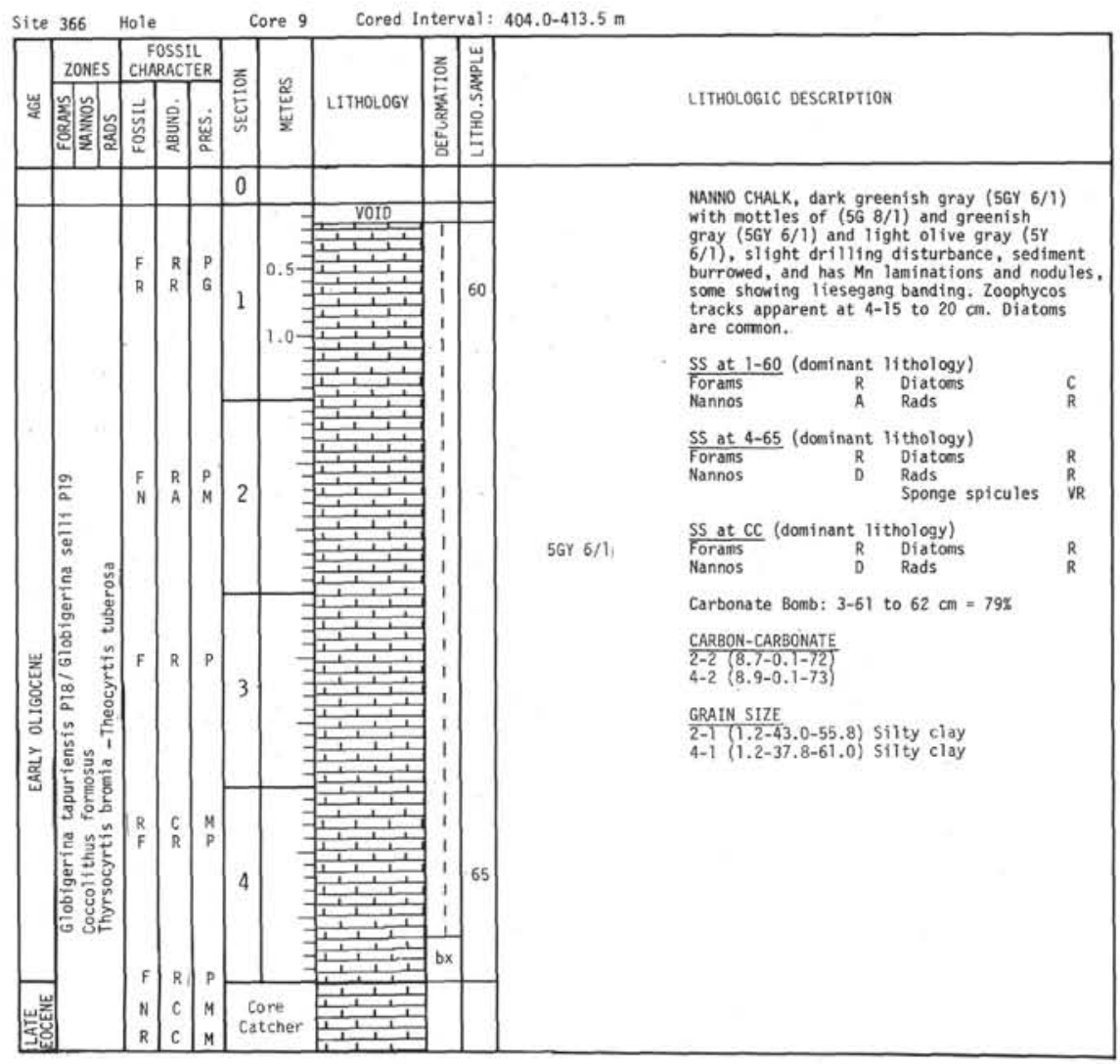

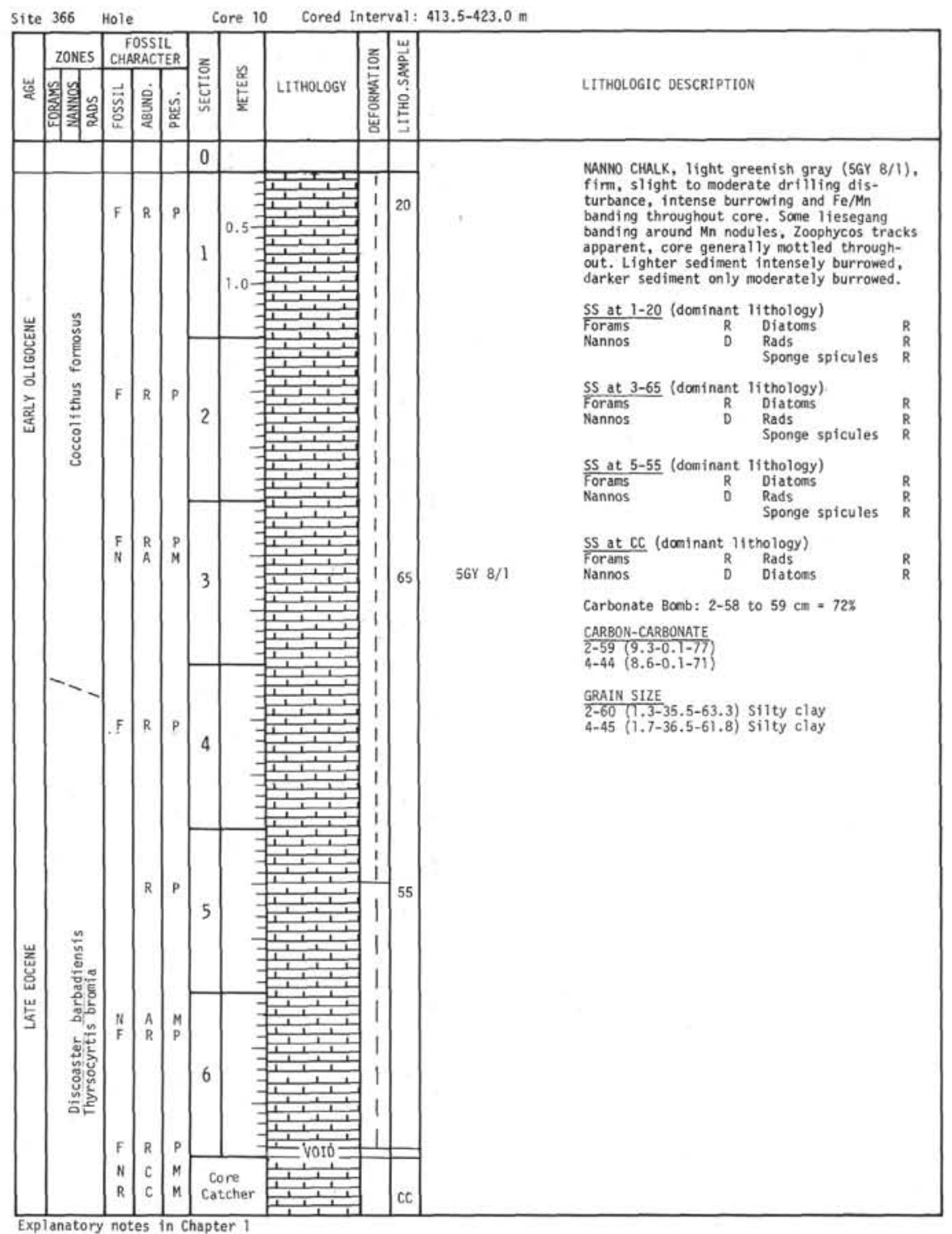



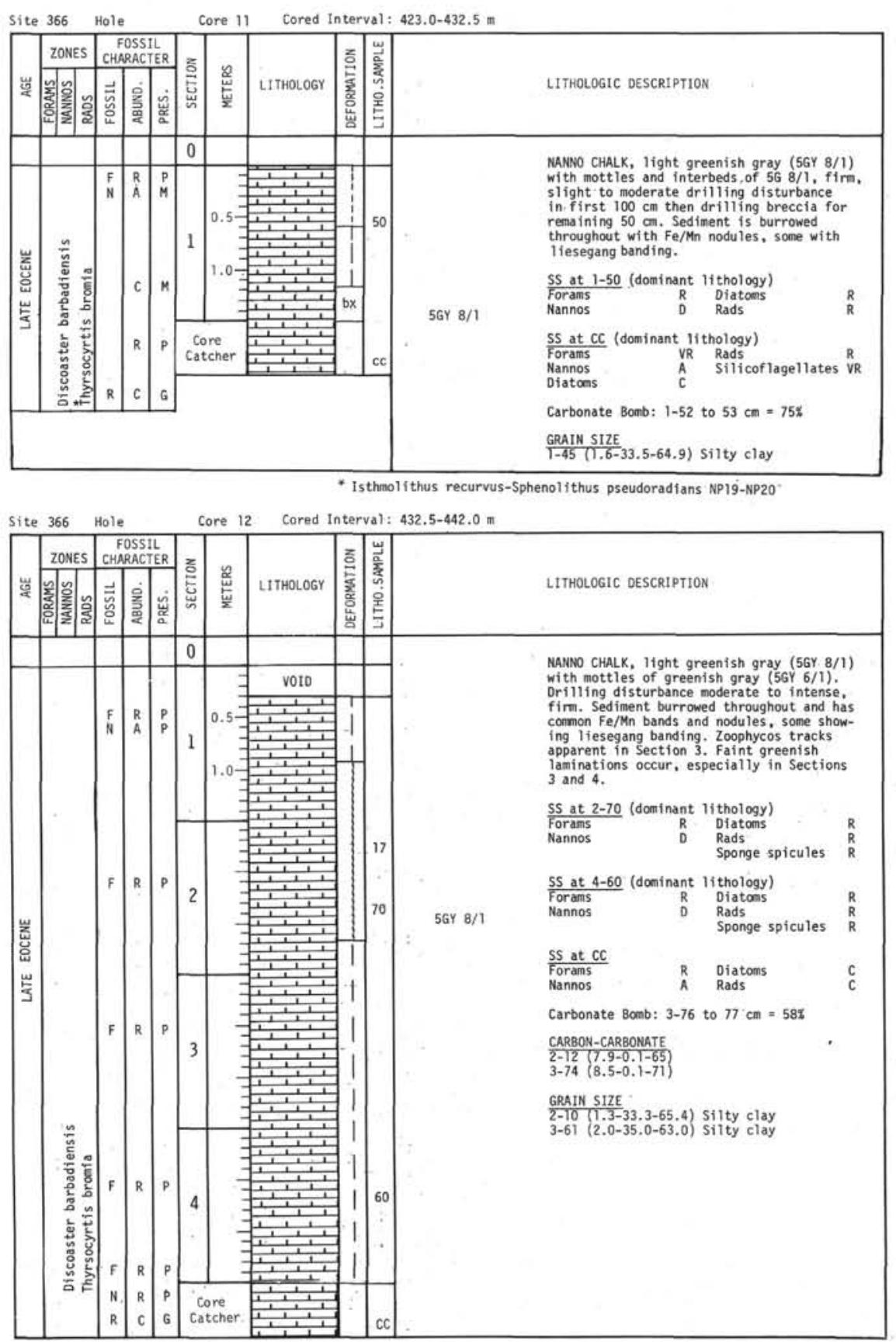

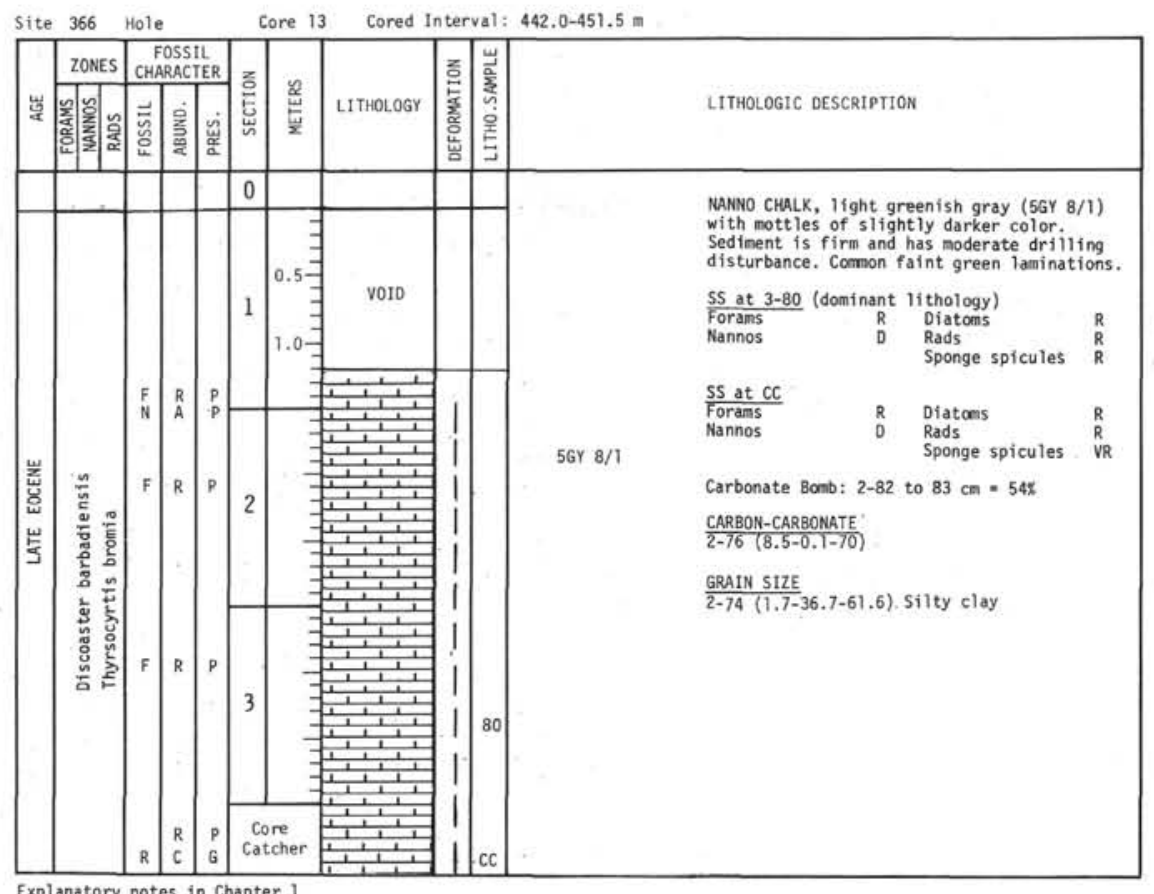

Exlanatory notes in chapter 


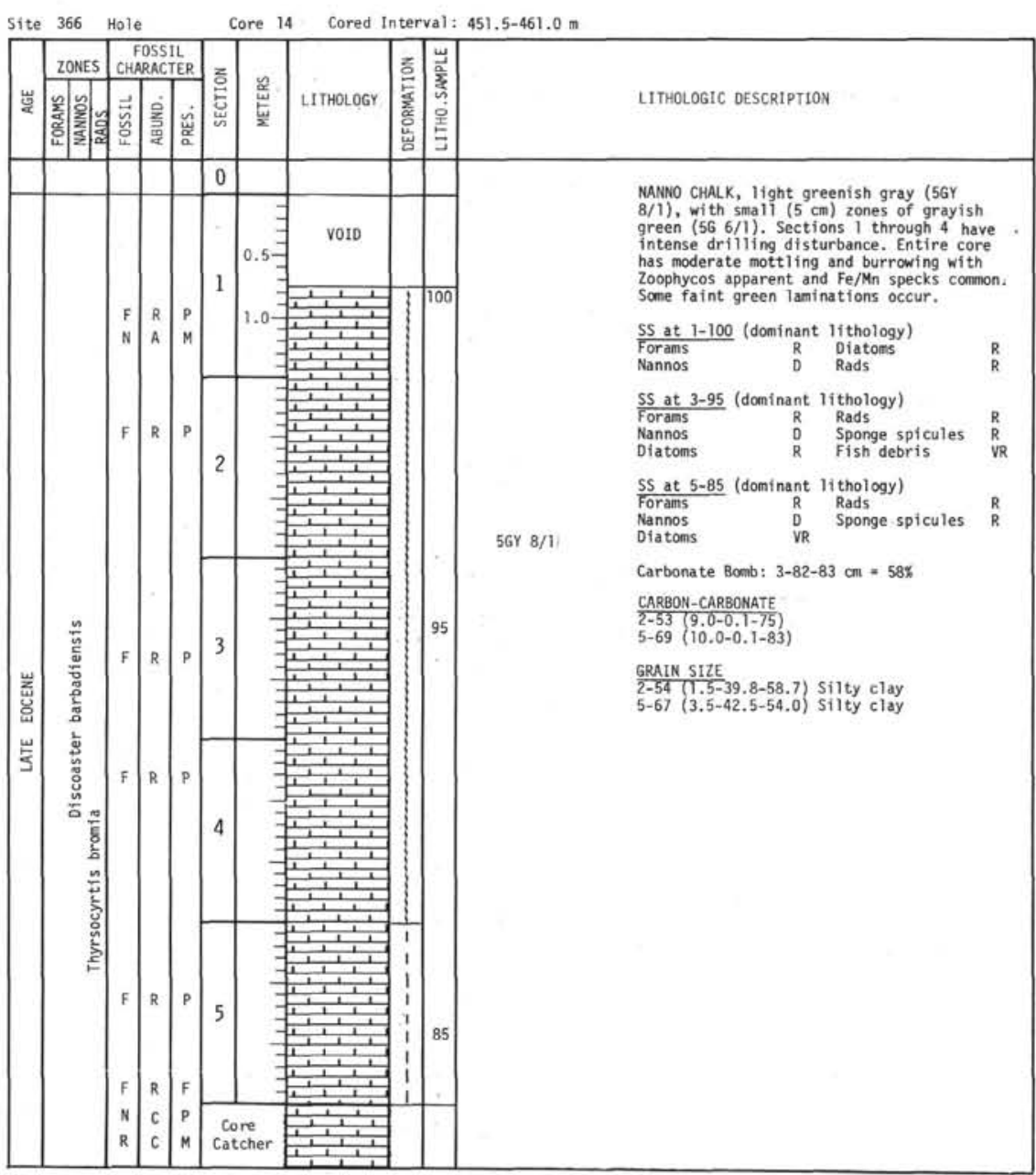

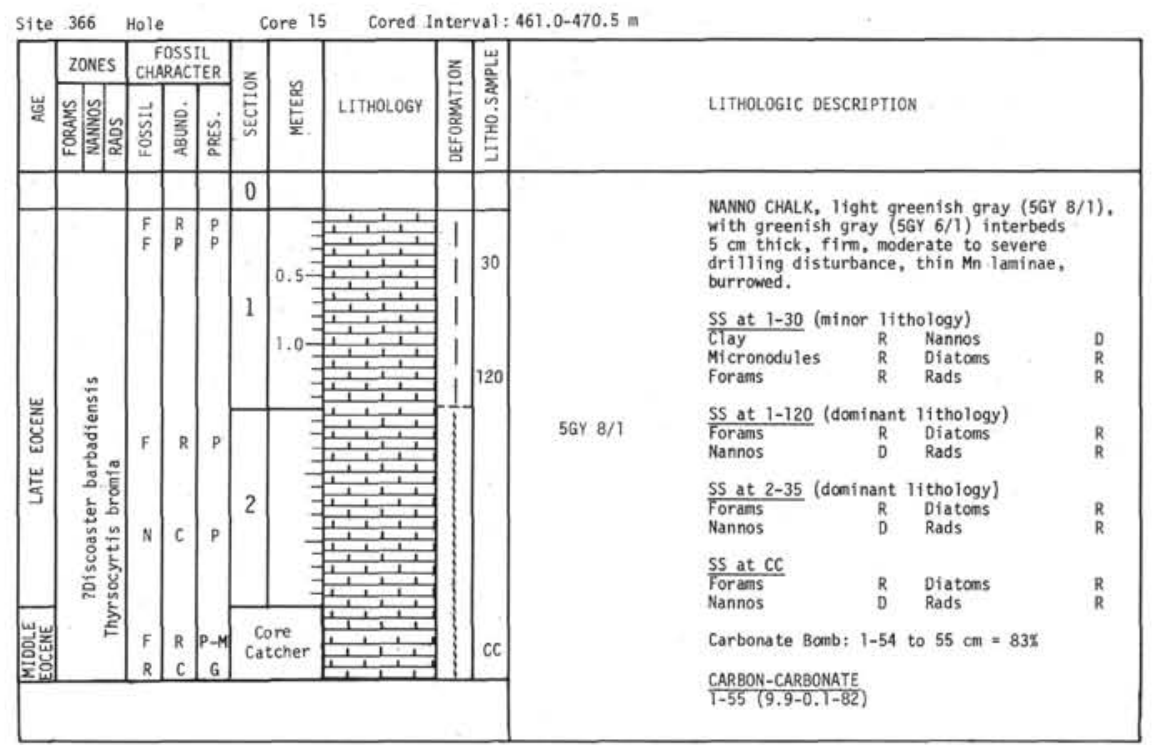

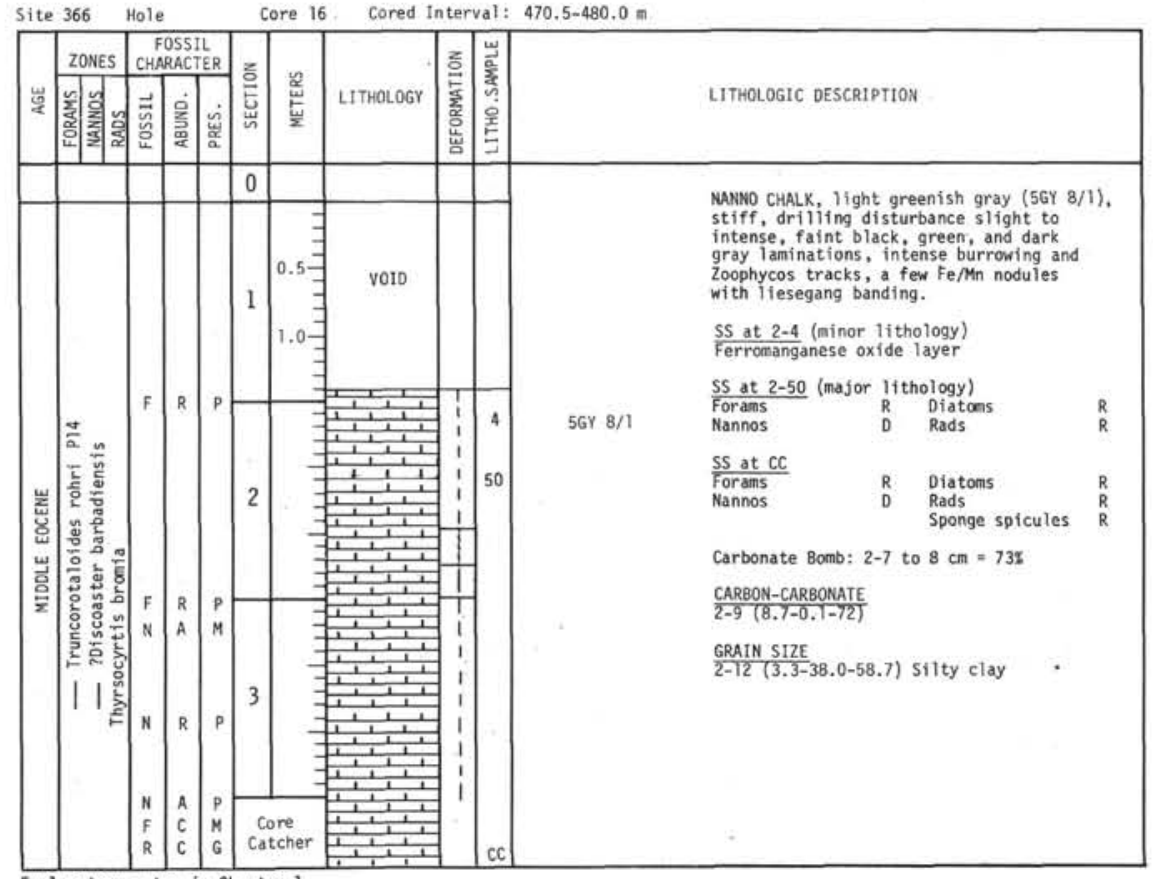




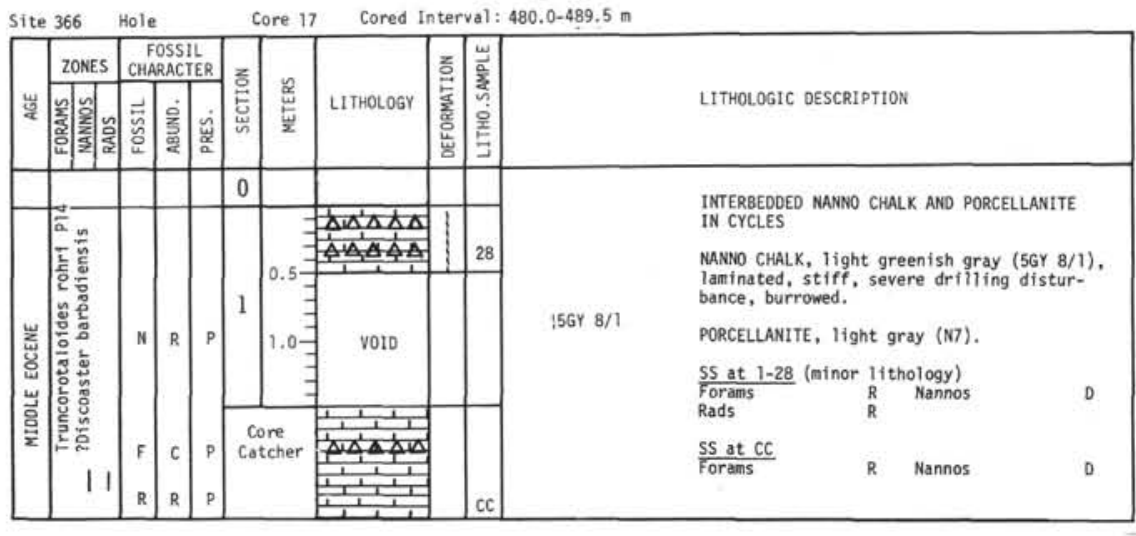

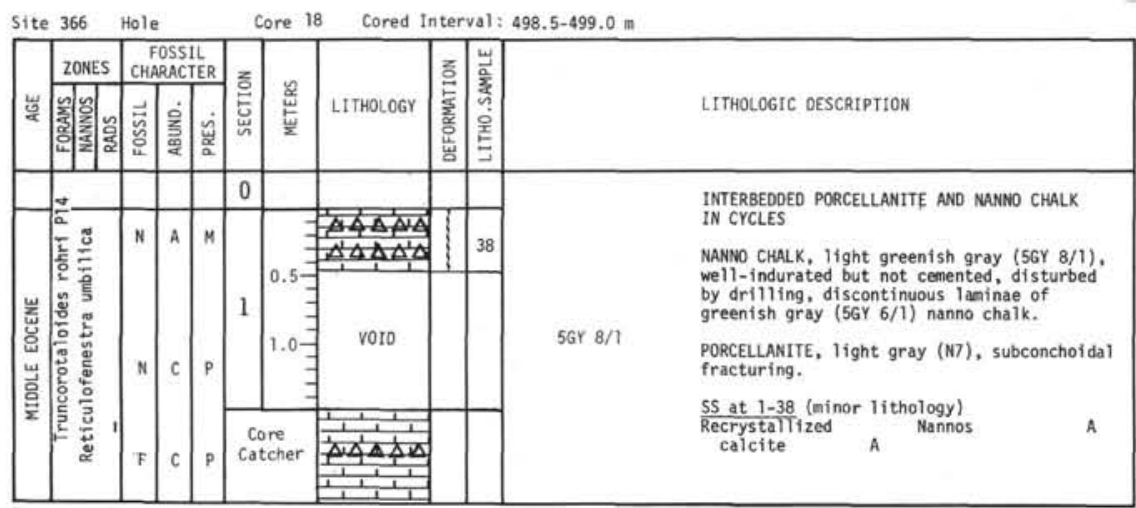

\begin{tabular}{|l|l|l|l|l|l|l|l|l|l|l|}
\hline Site 366 & Cole \\
\hline
\end{tabular}

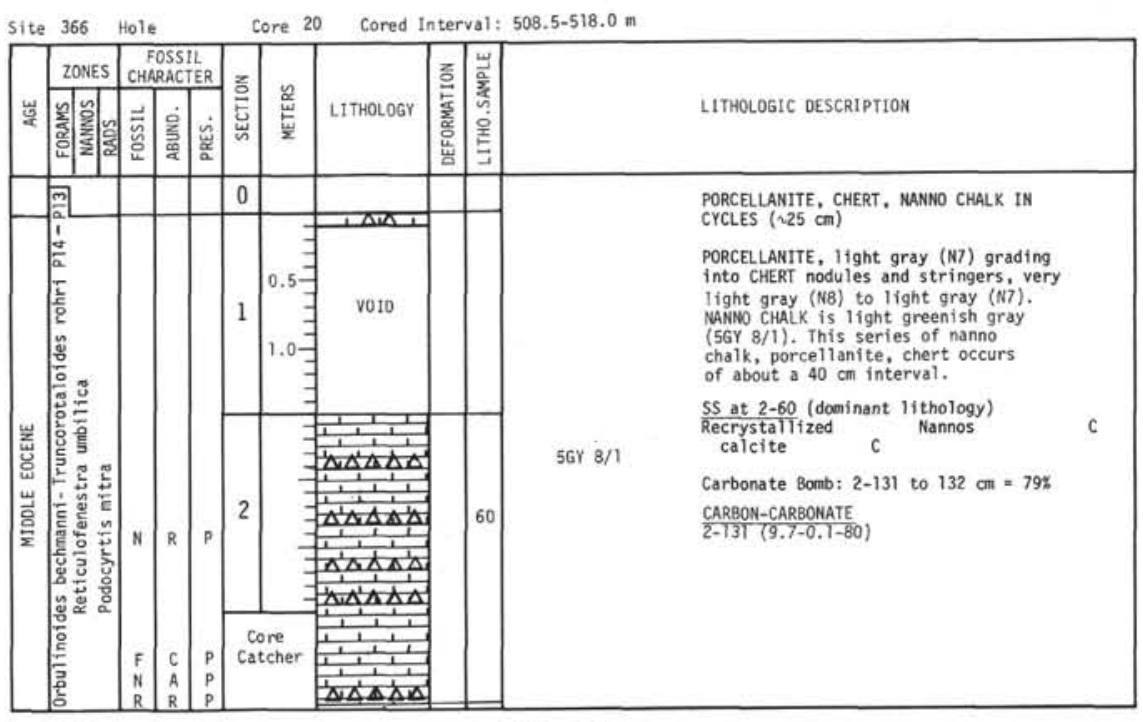

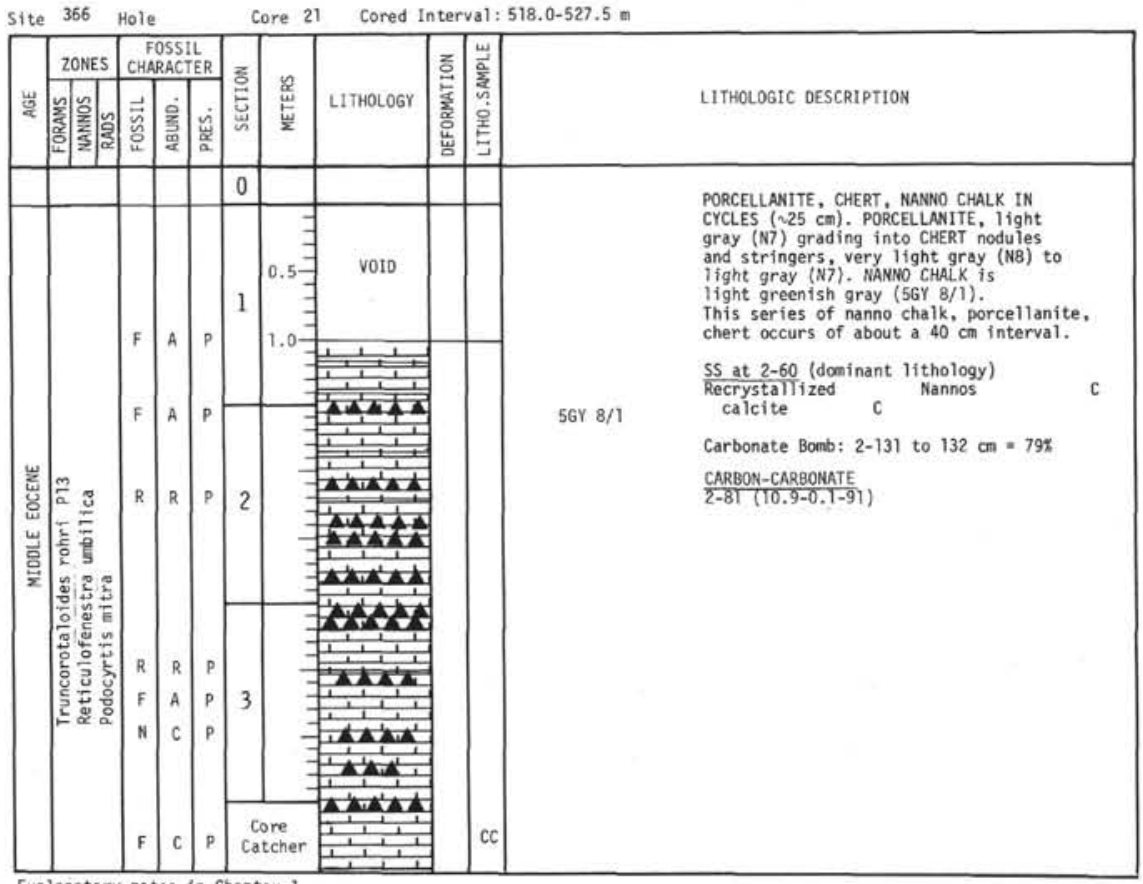

Explanatory notes in Chapter 1 


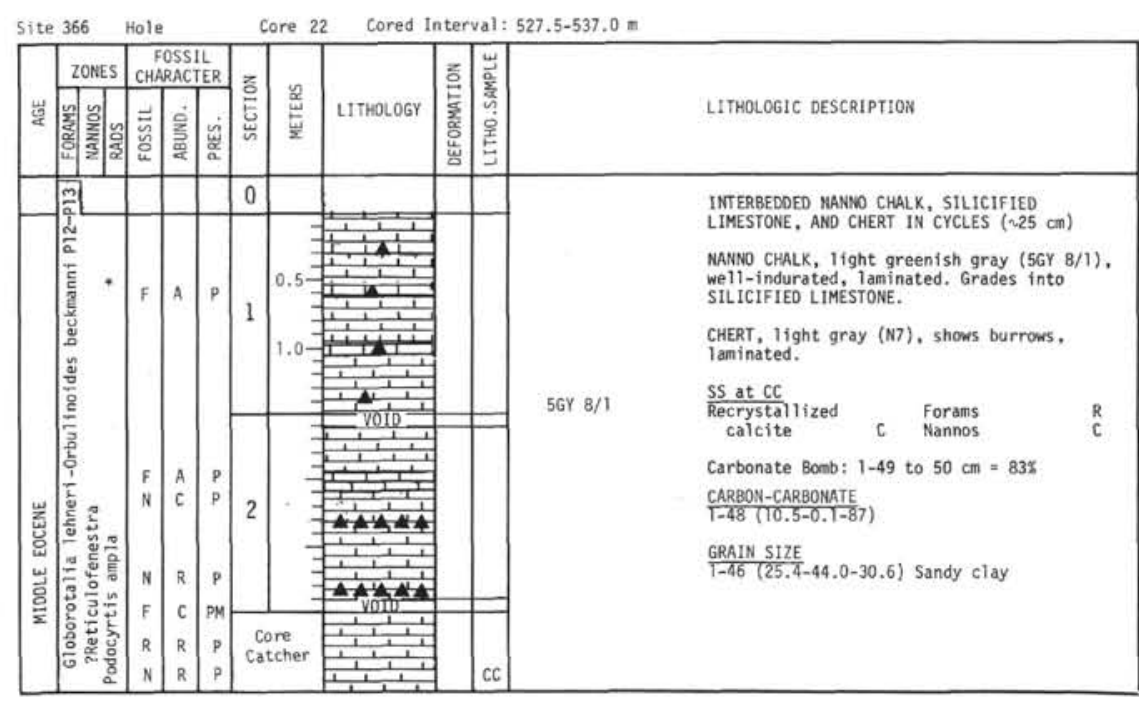

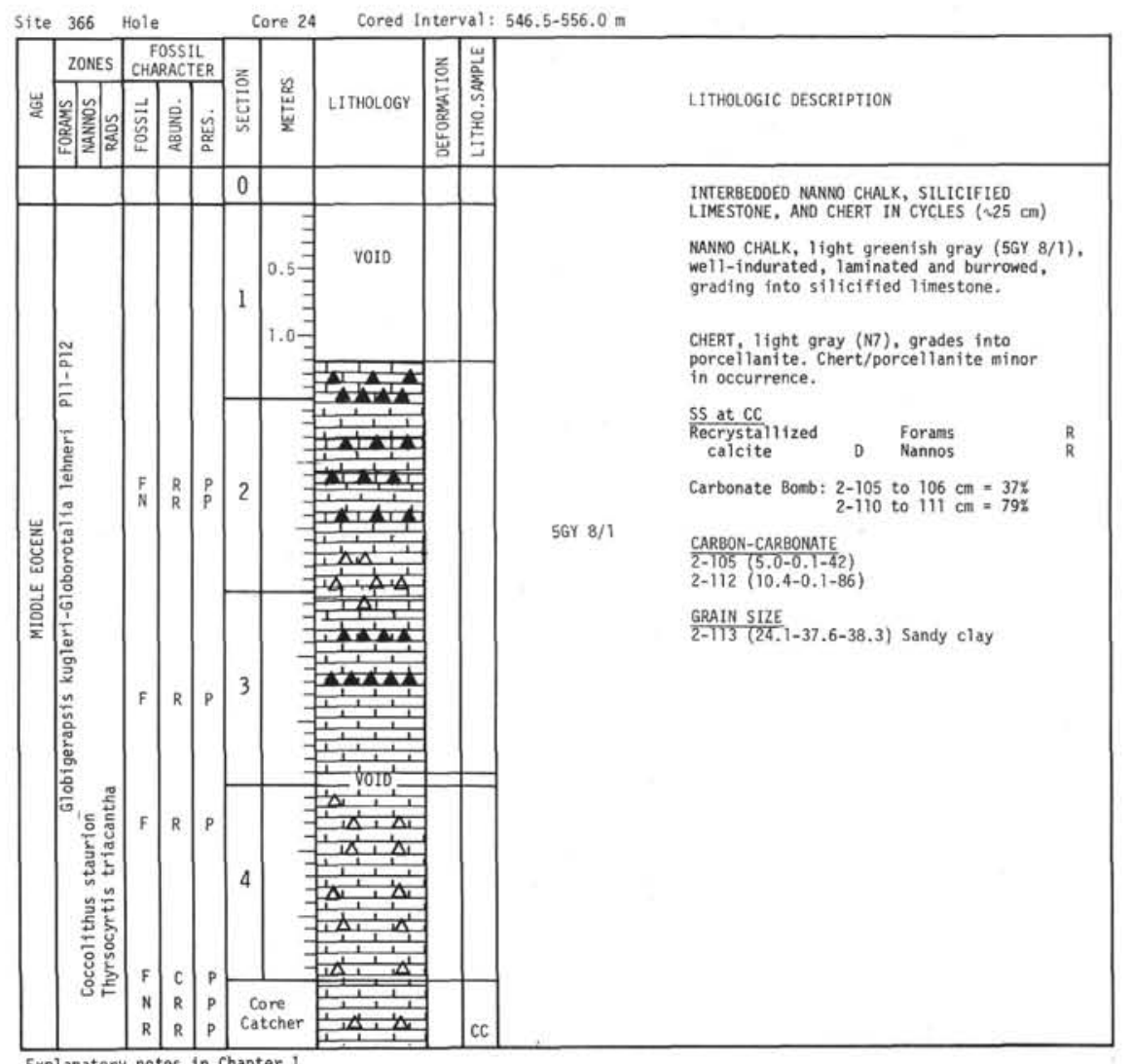

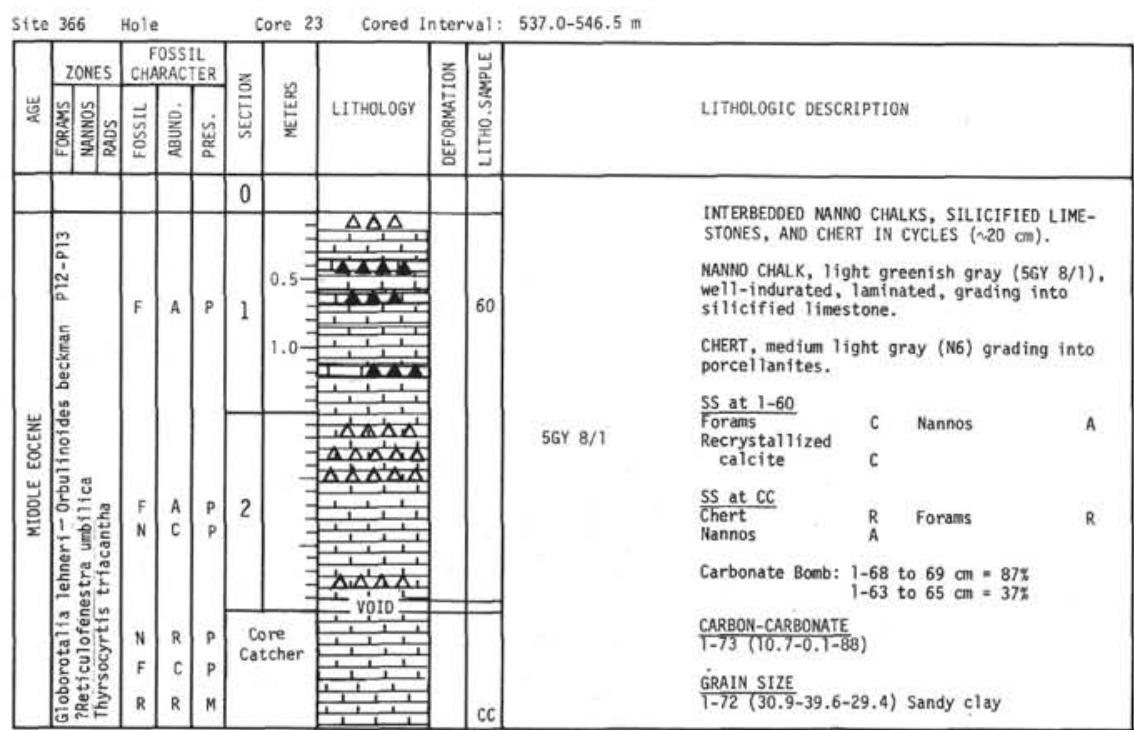




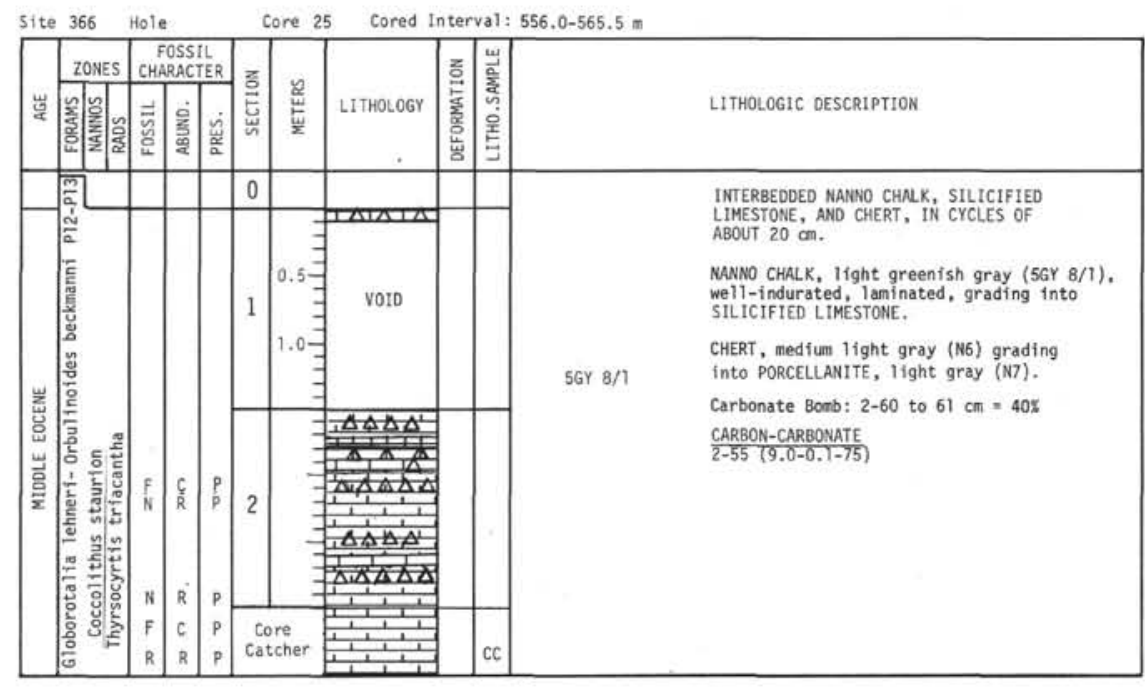

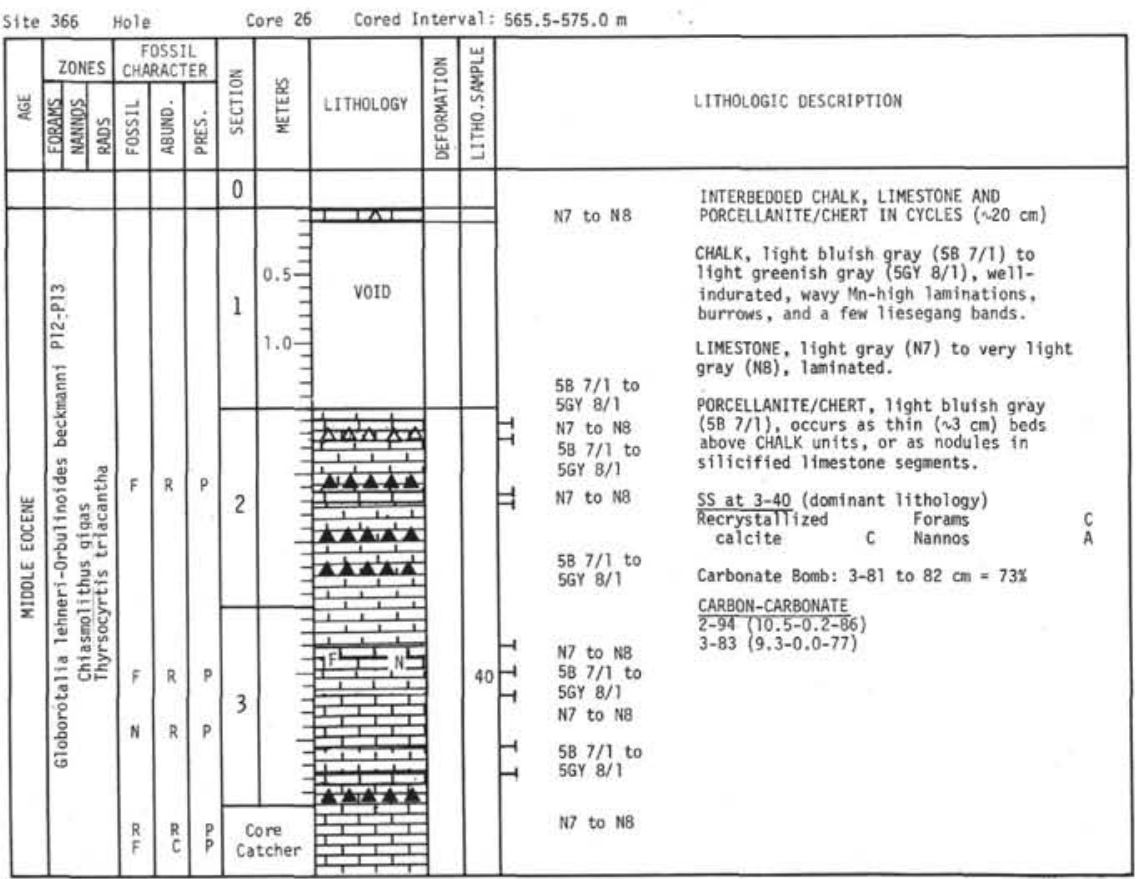

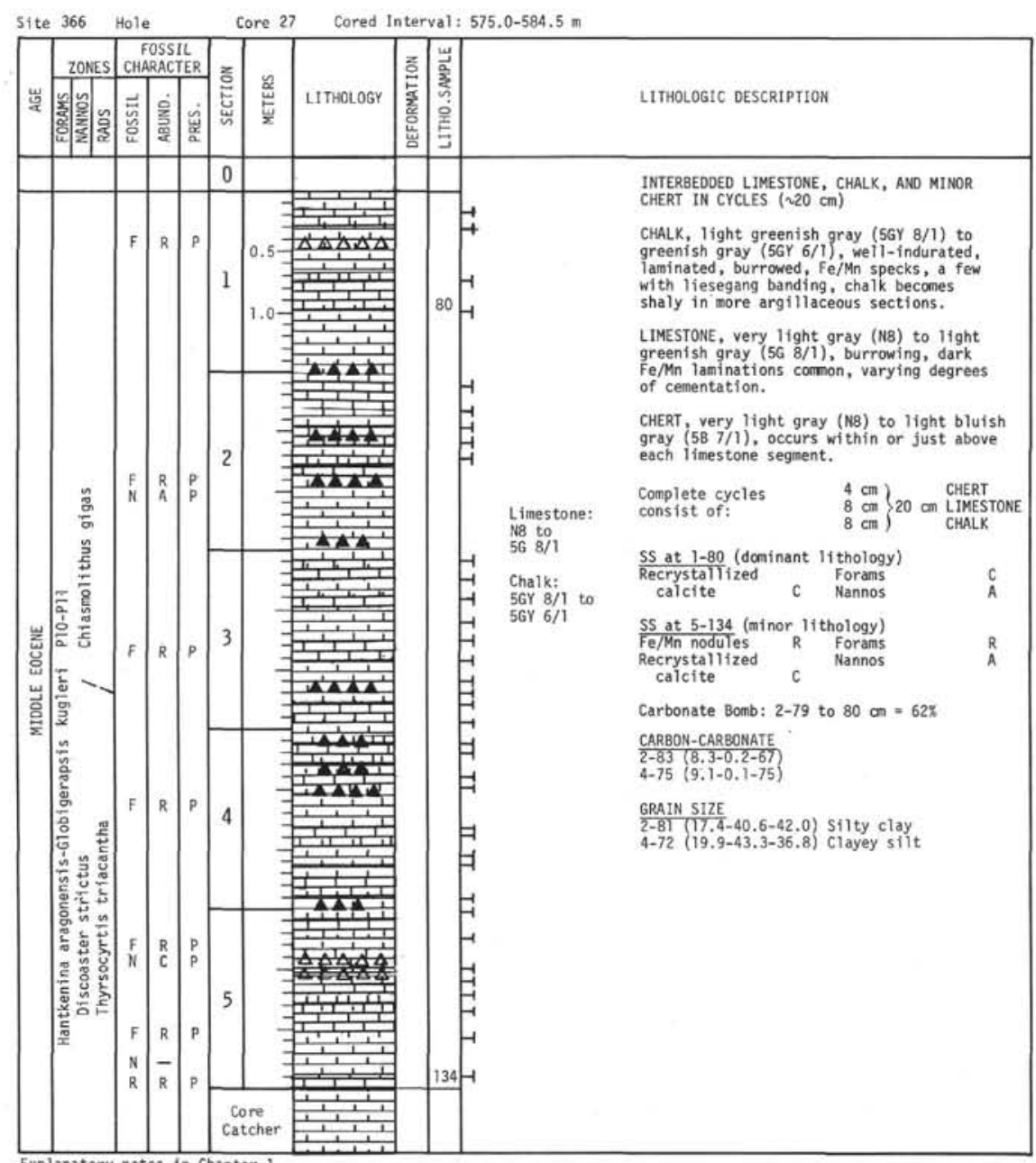

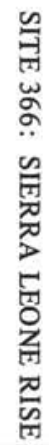




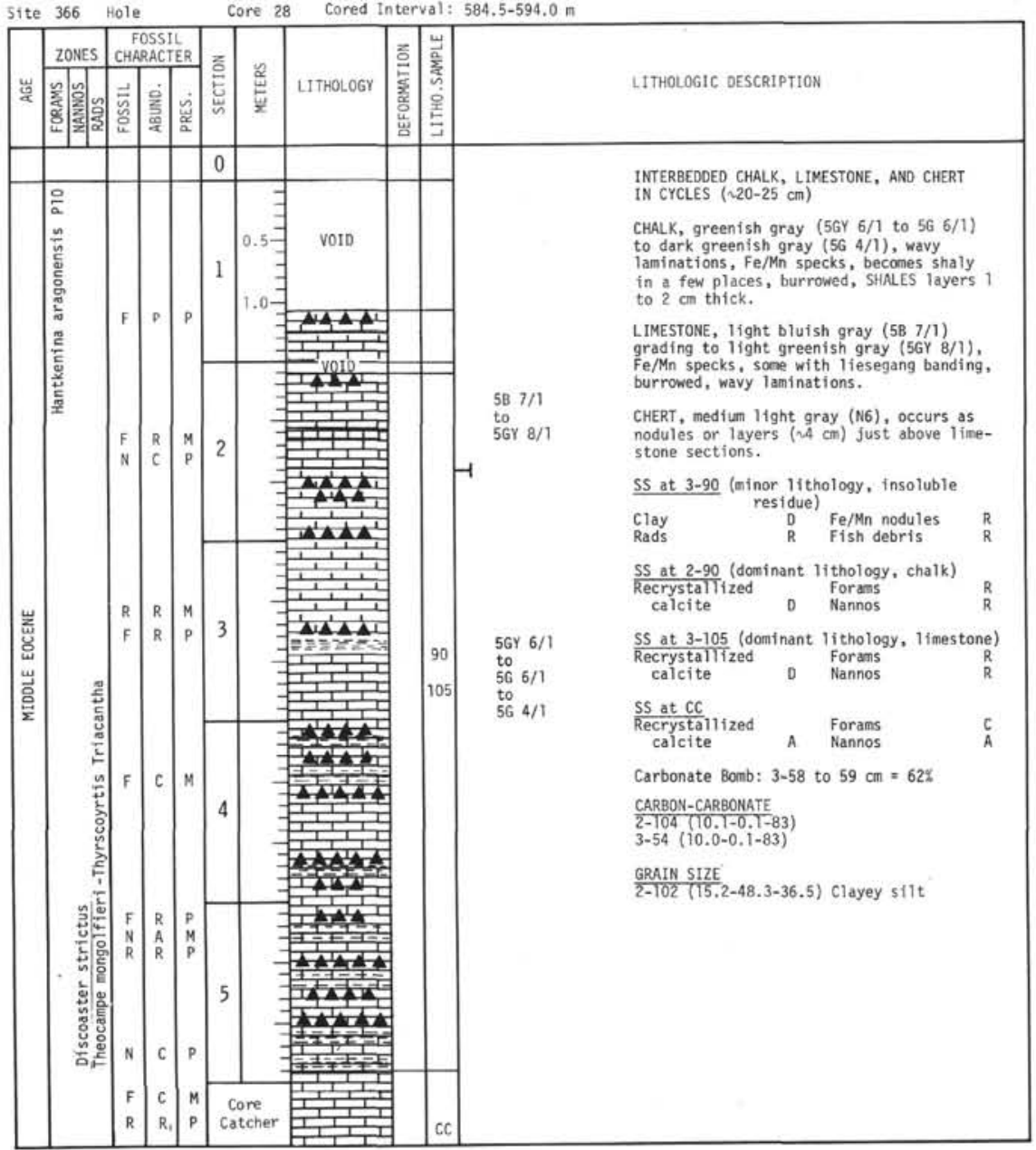

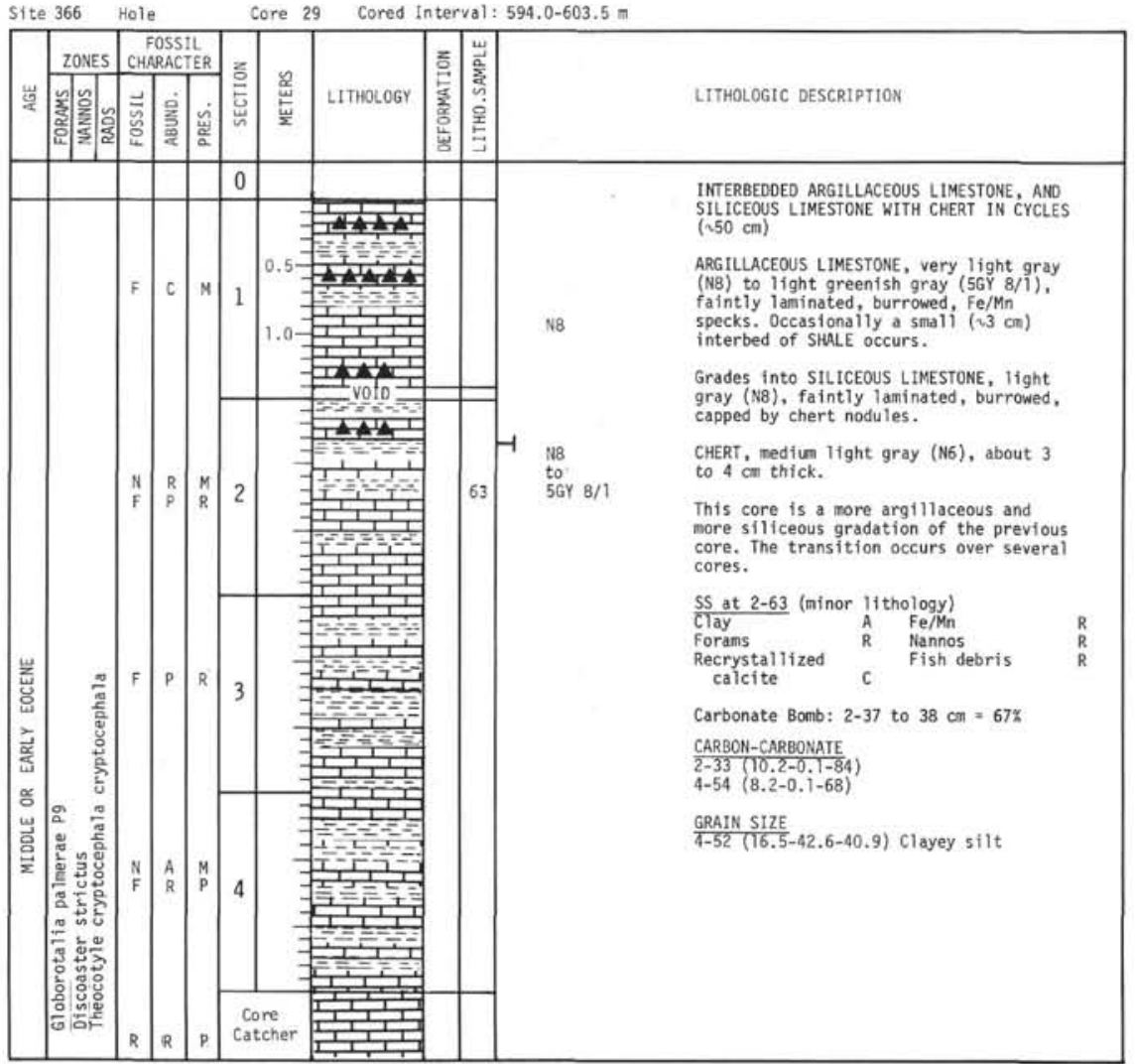

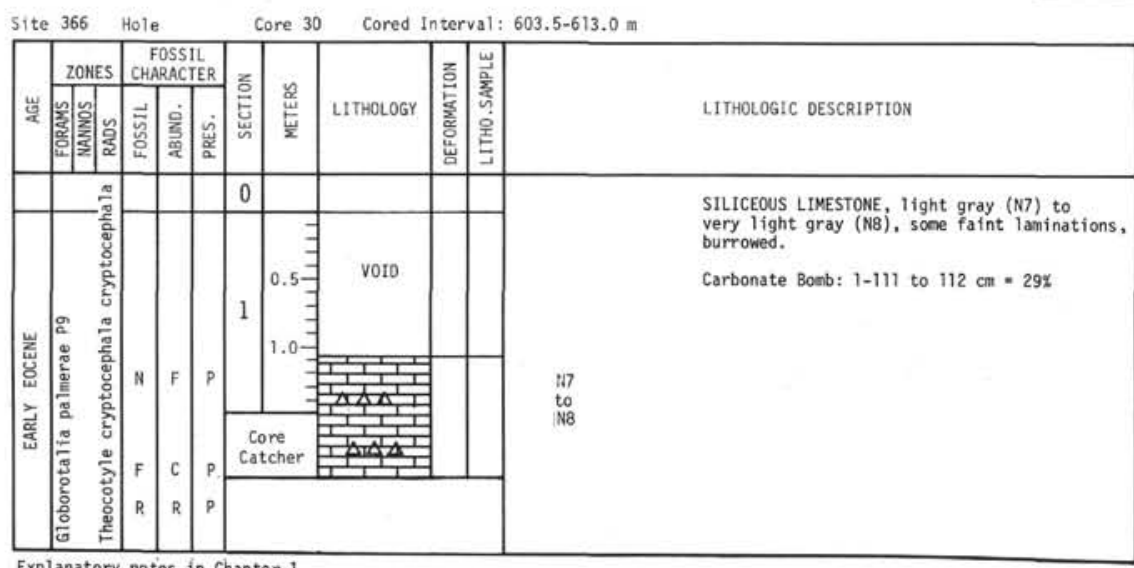




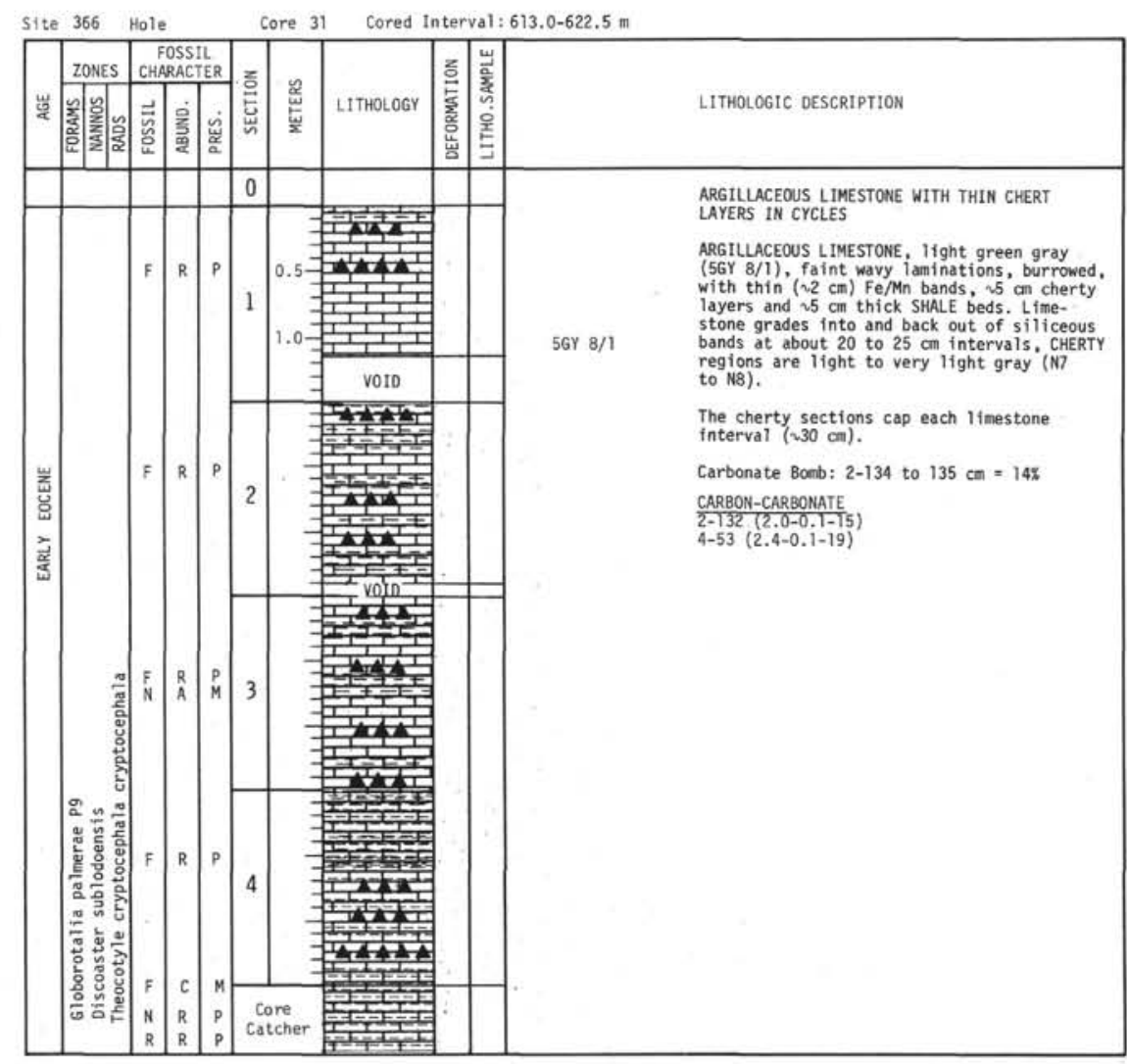

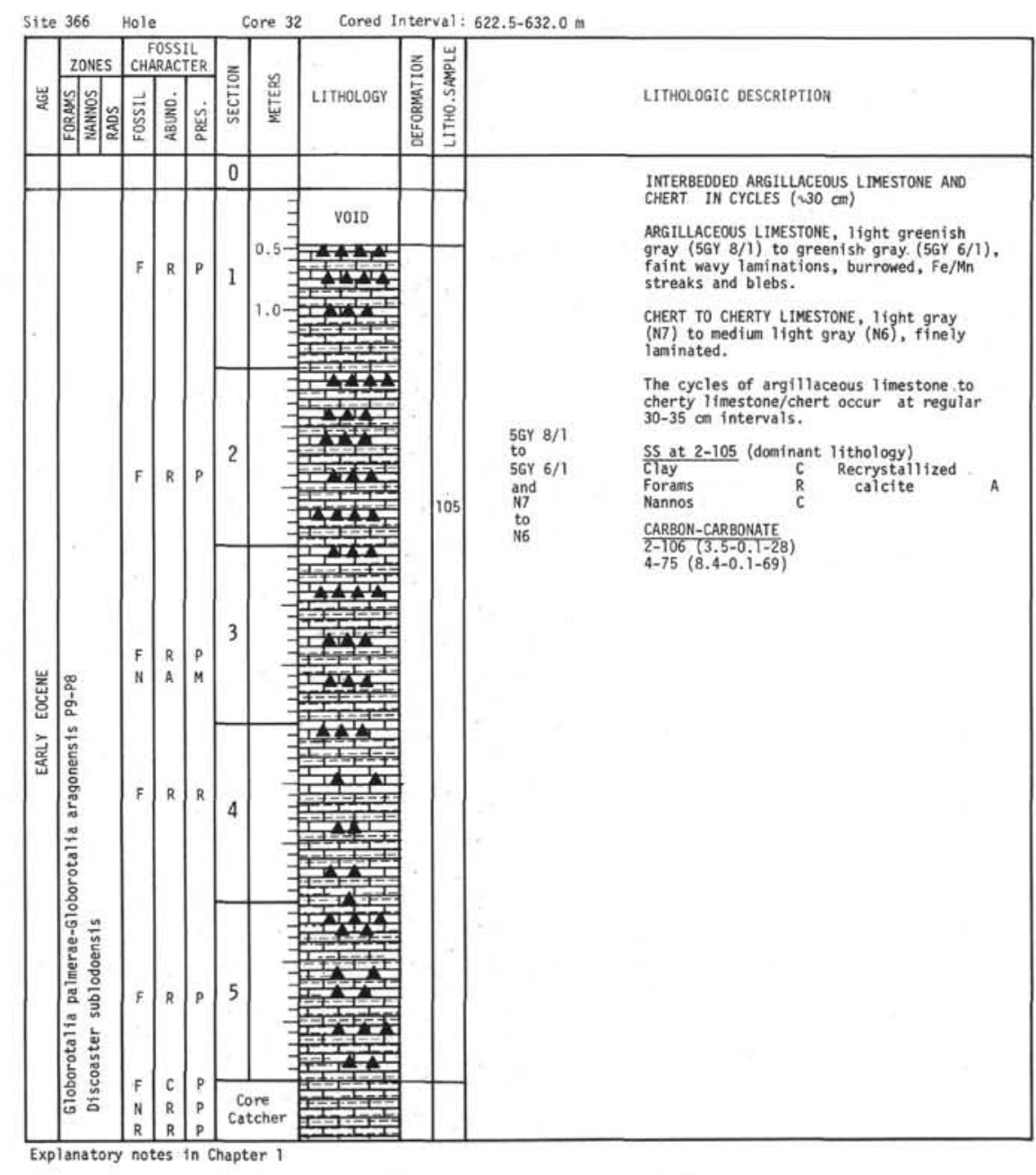

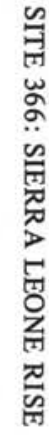


\&

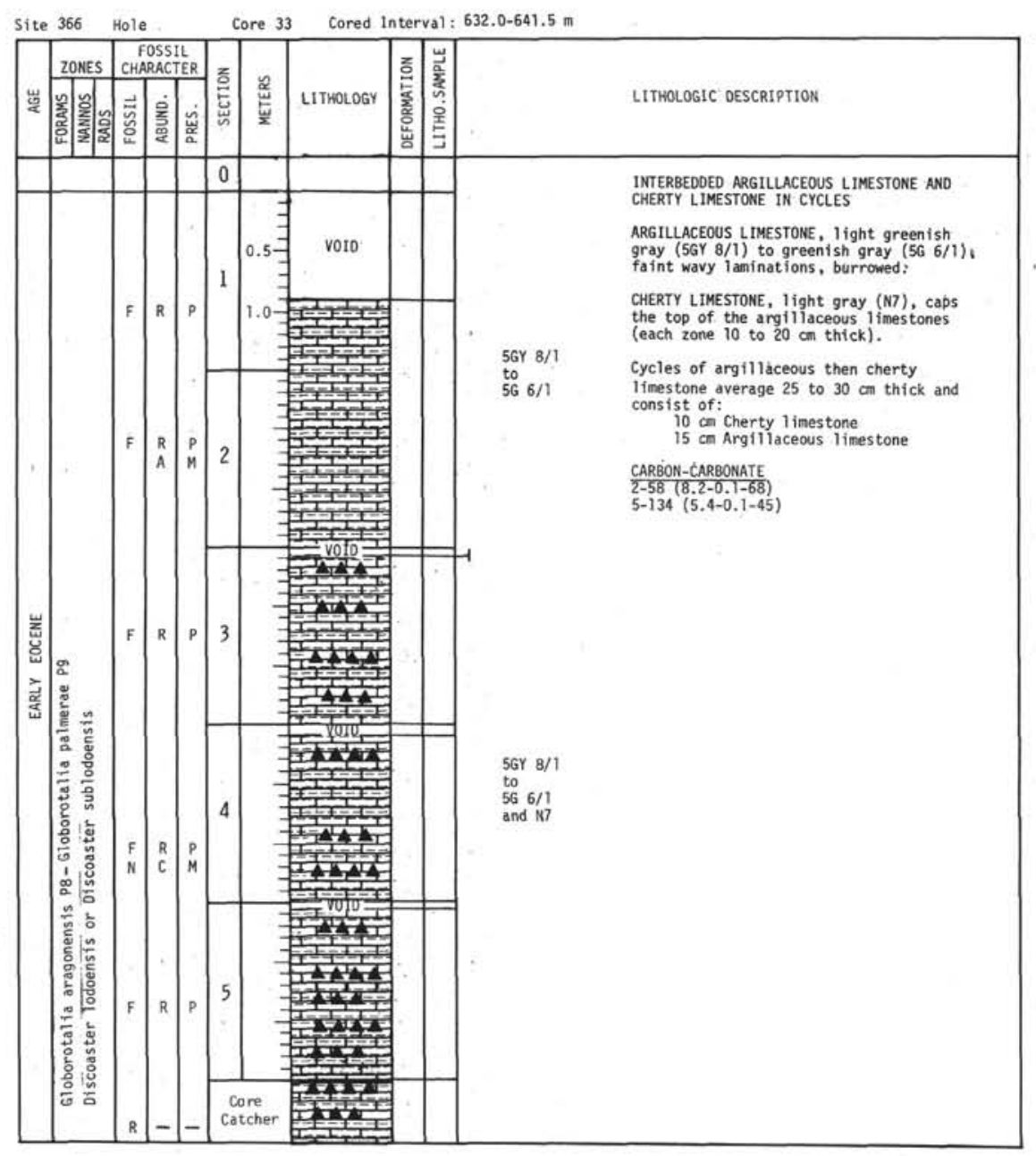

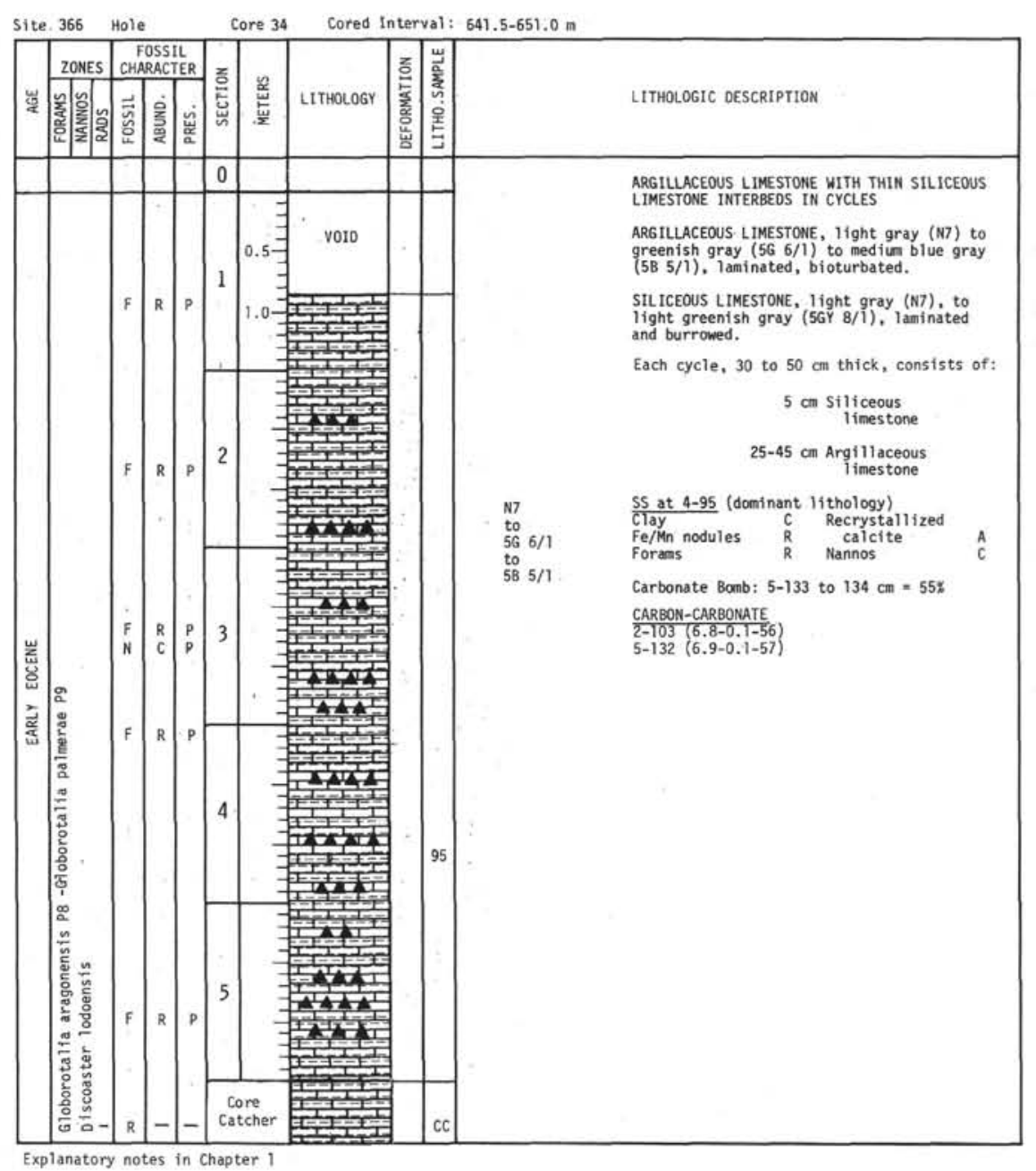



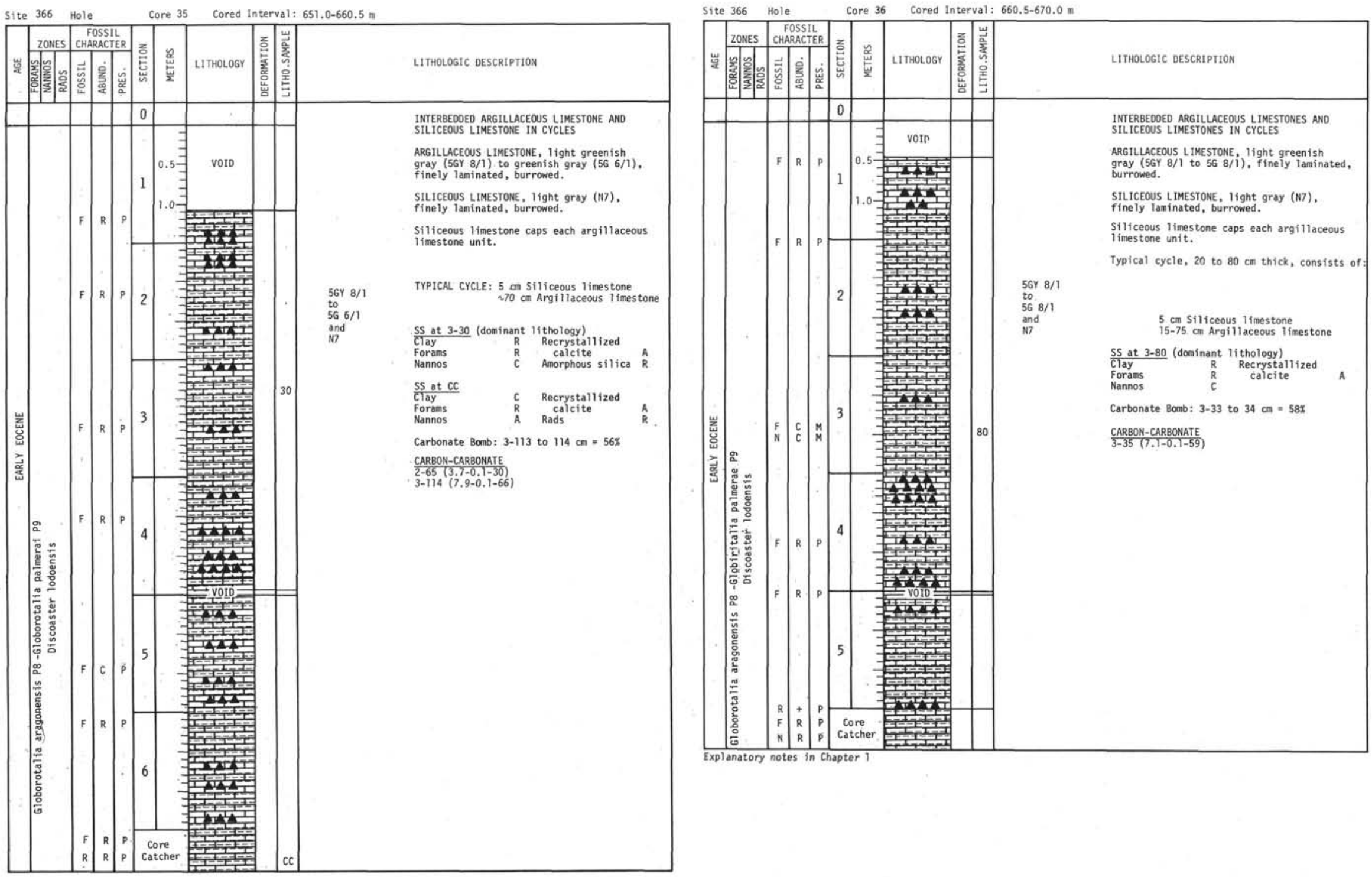
ร

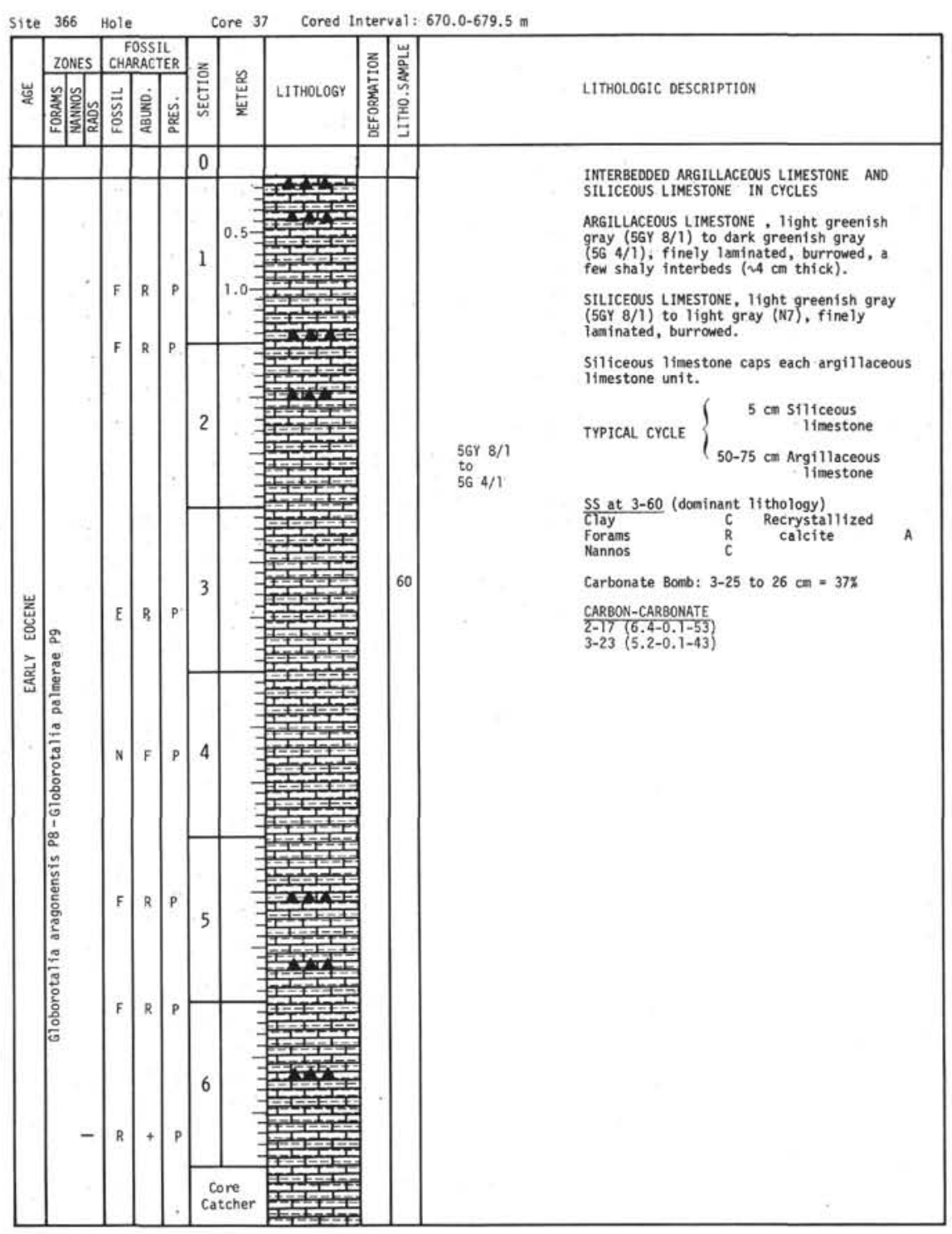

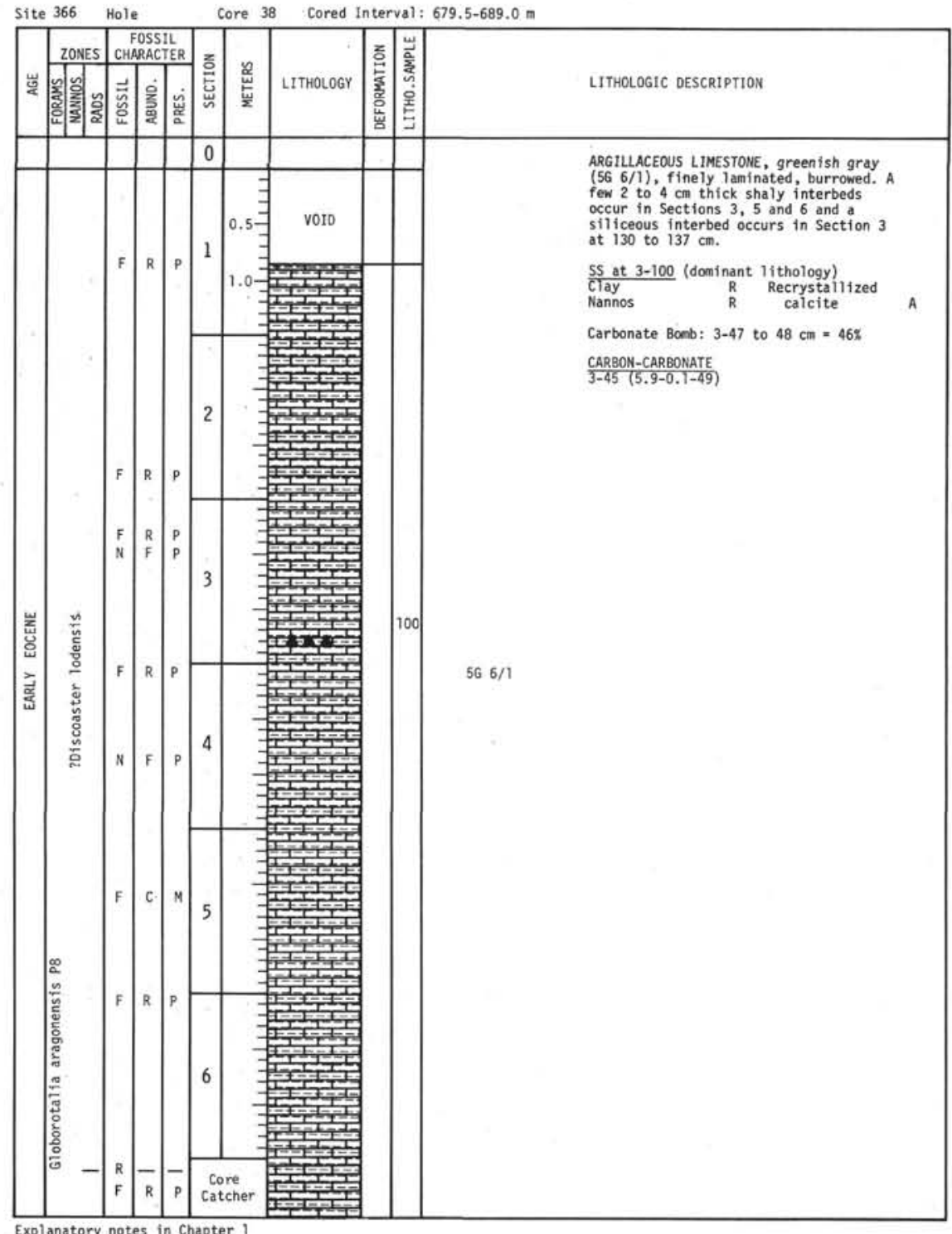



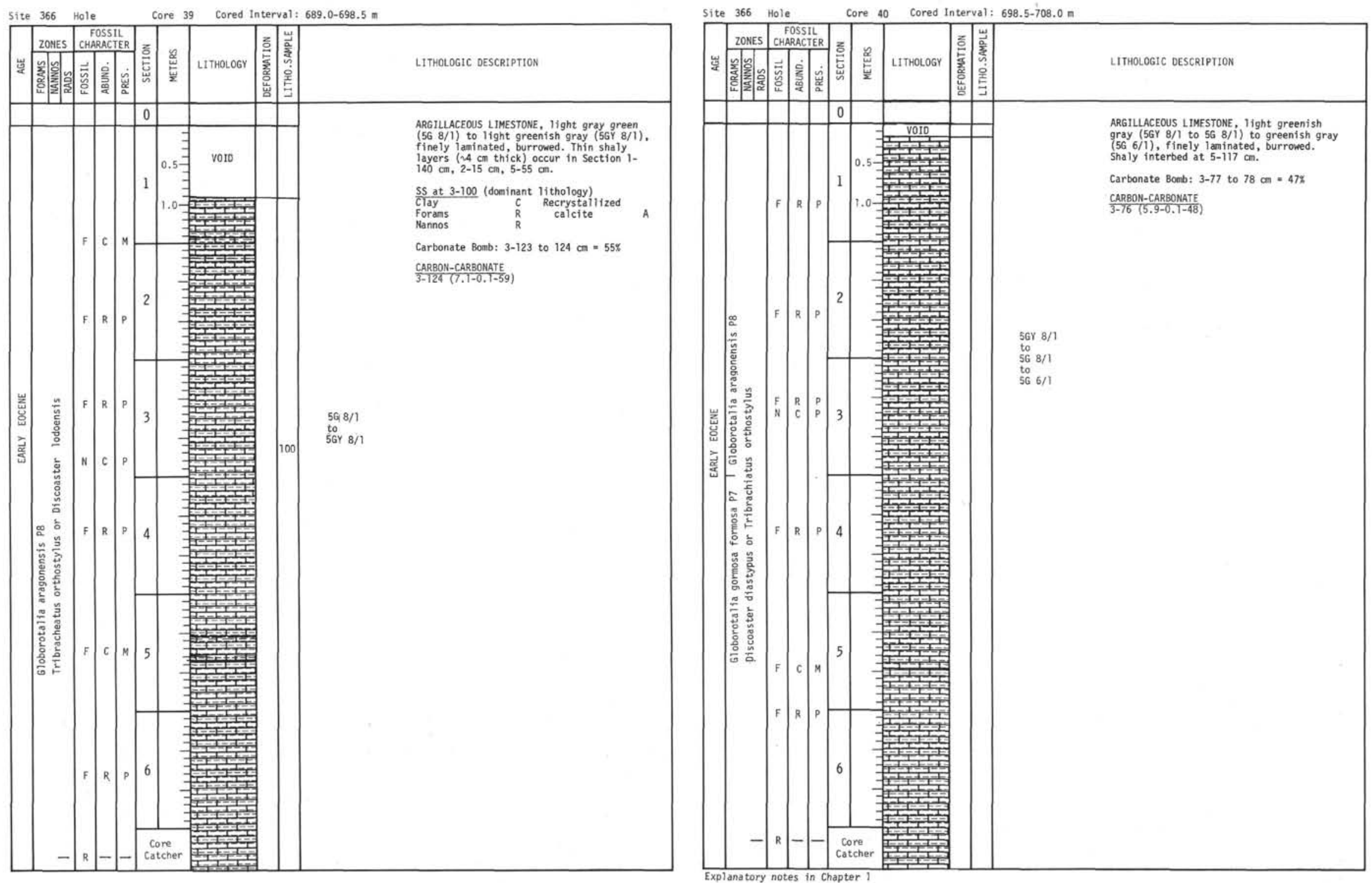

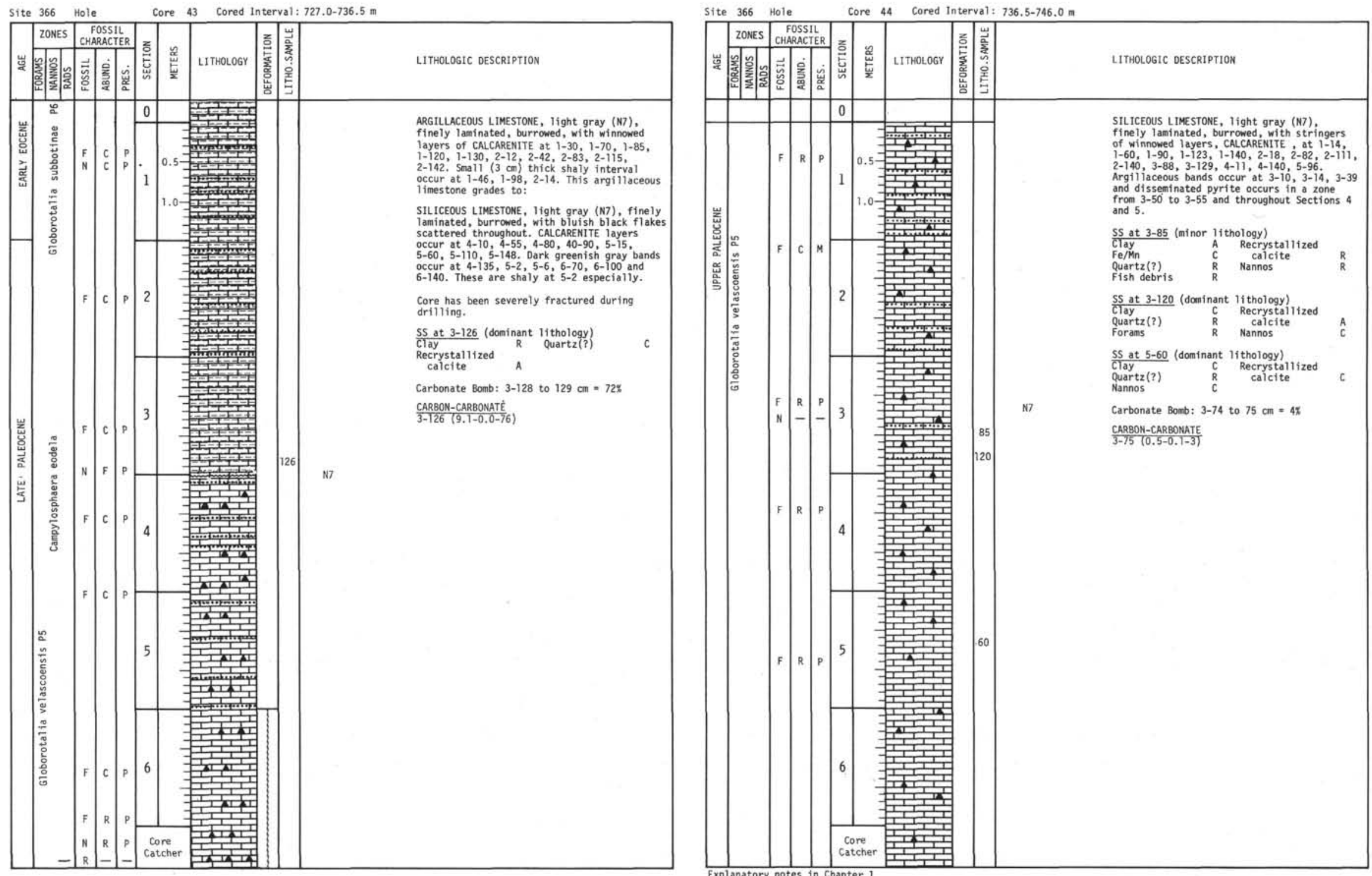


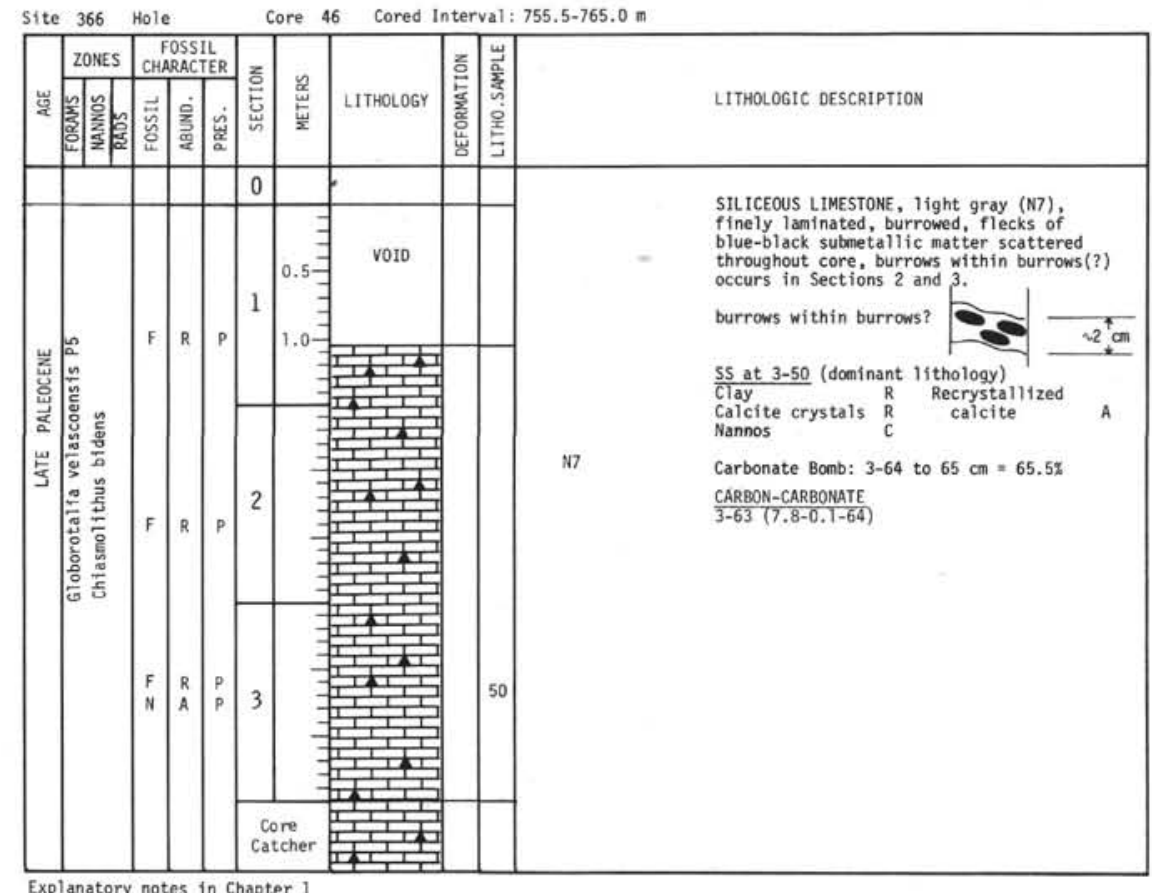

Explanatory notes in Chapter 1 

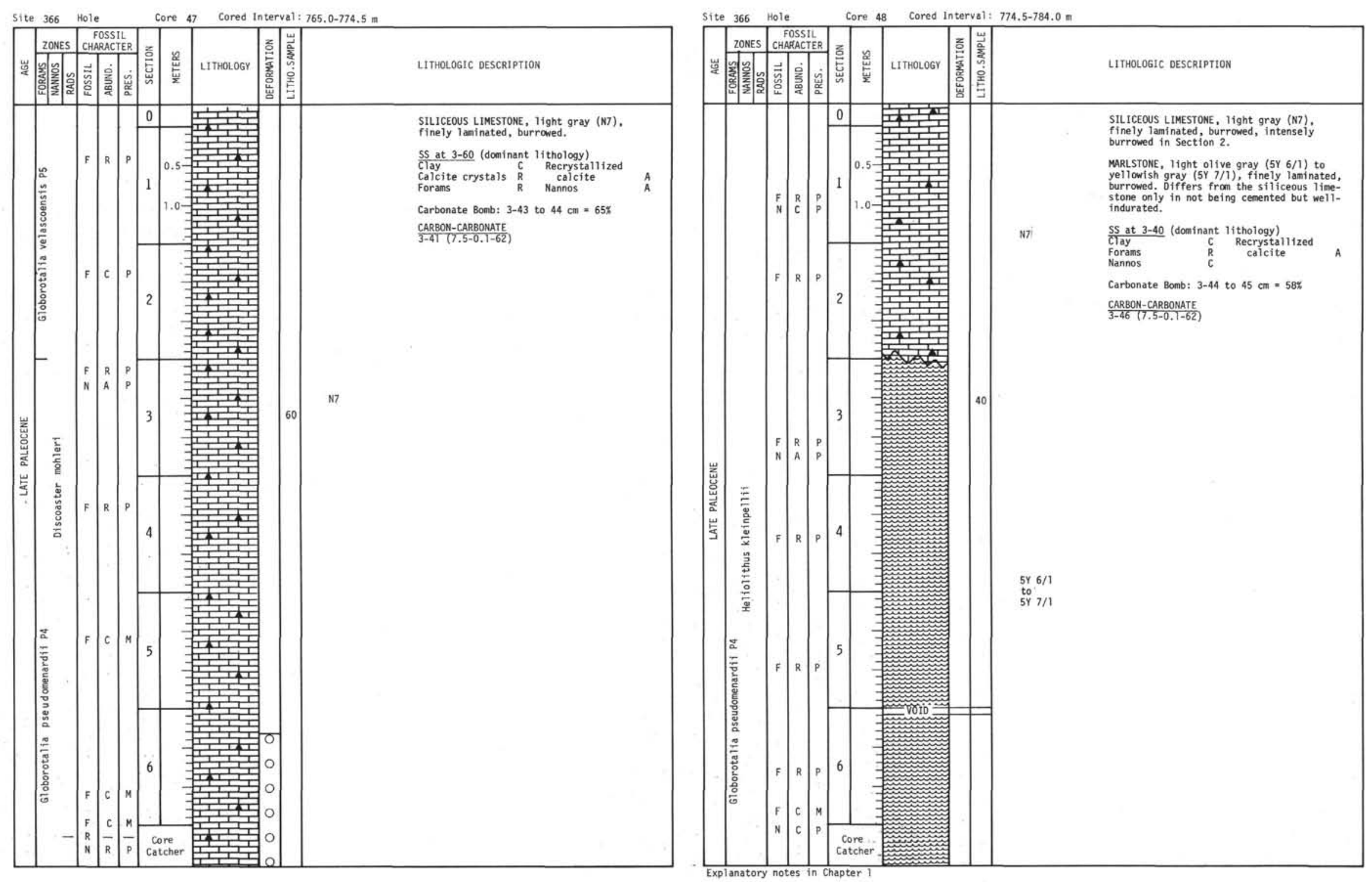


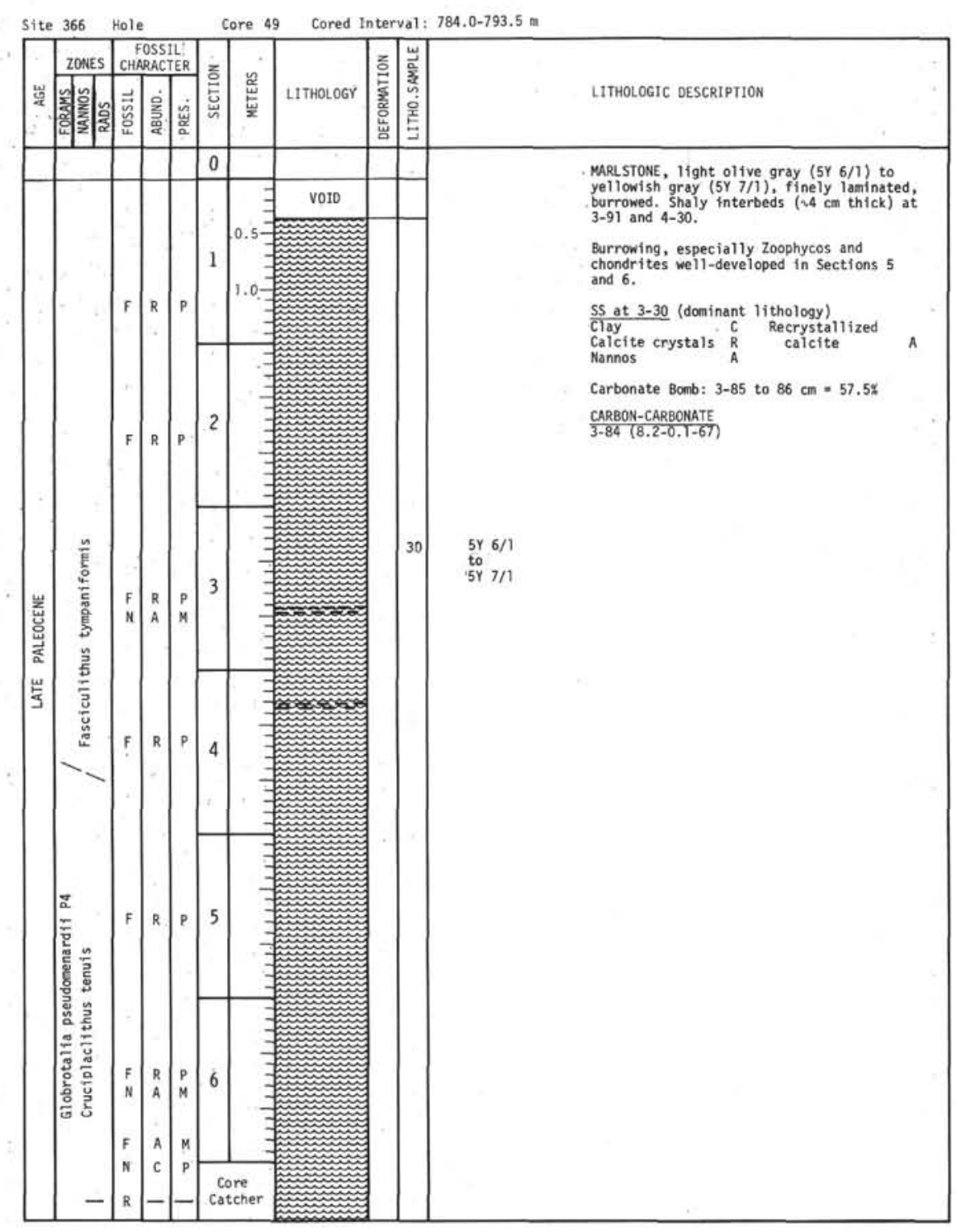

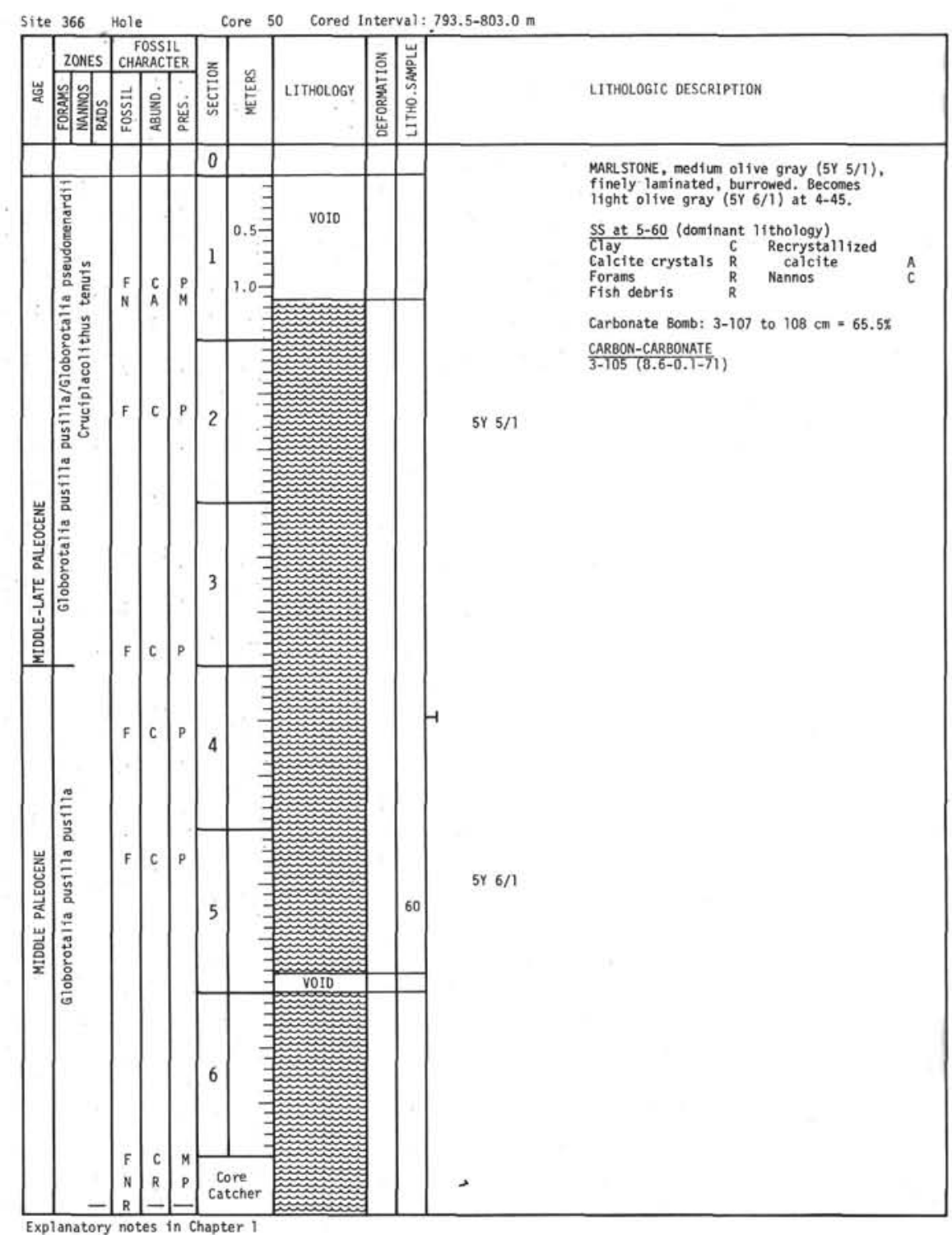



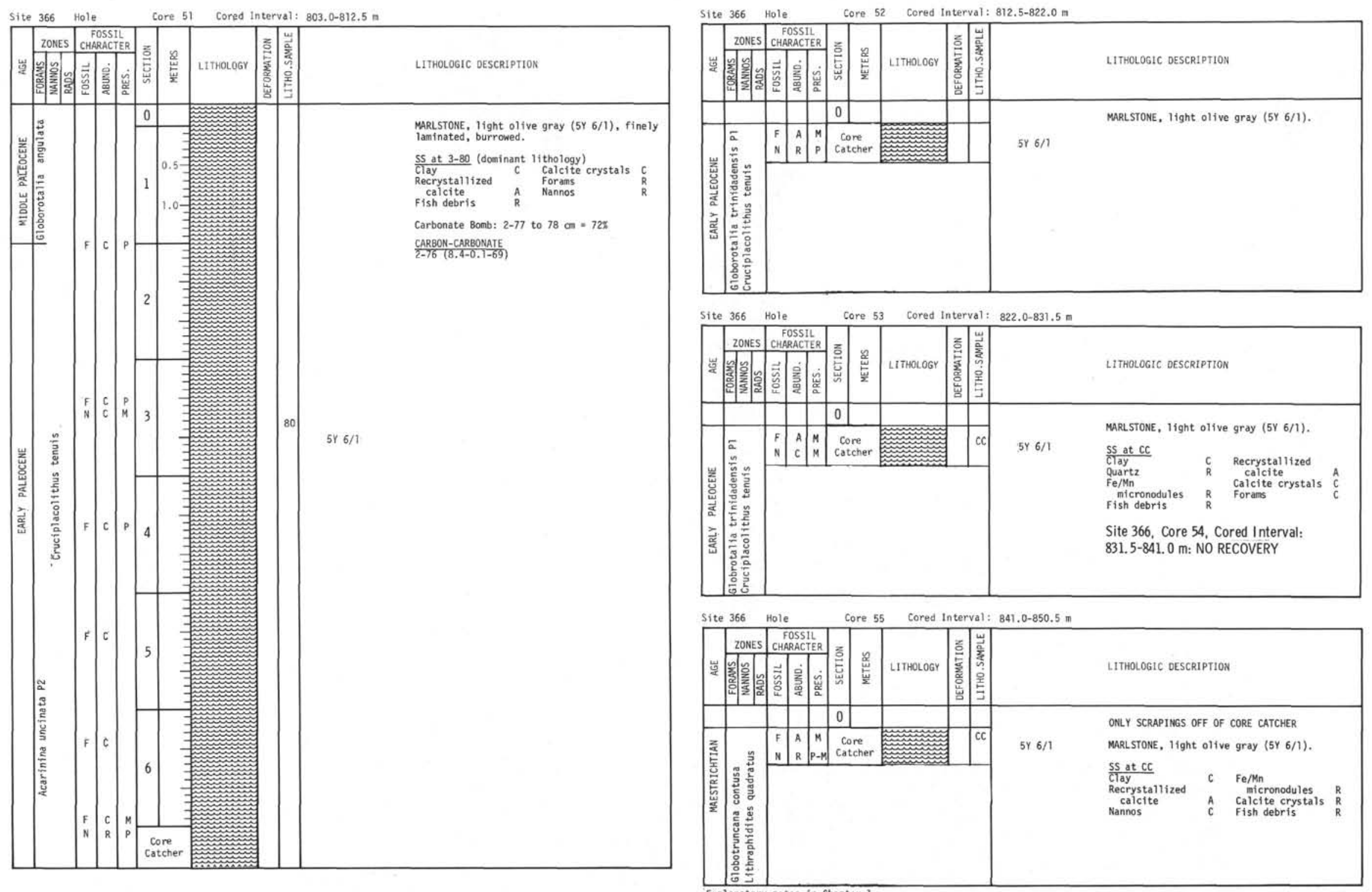


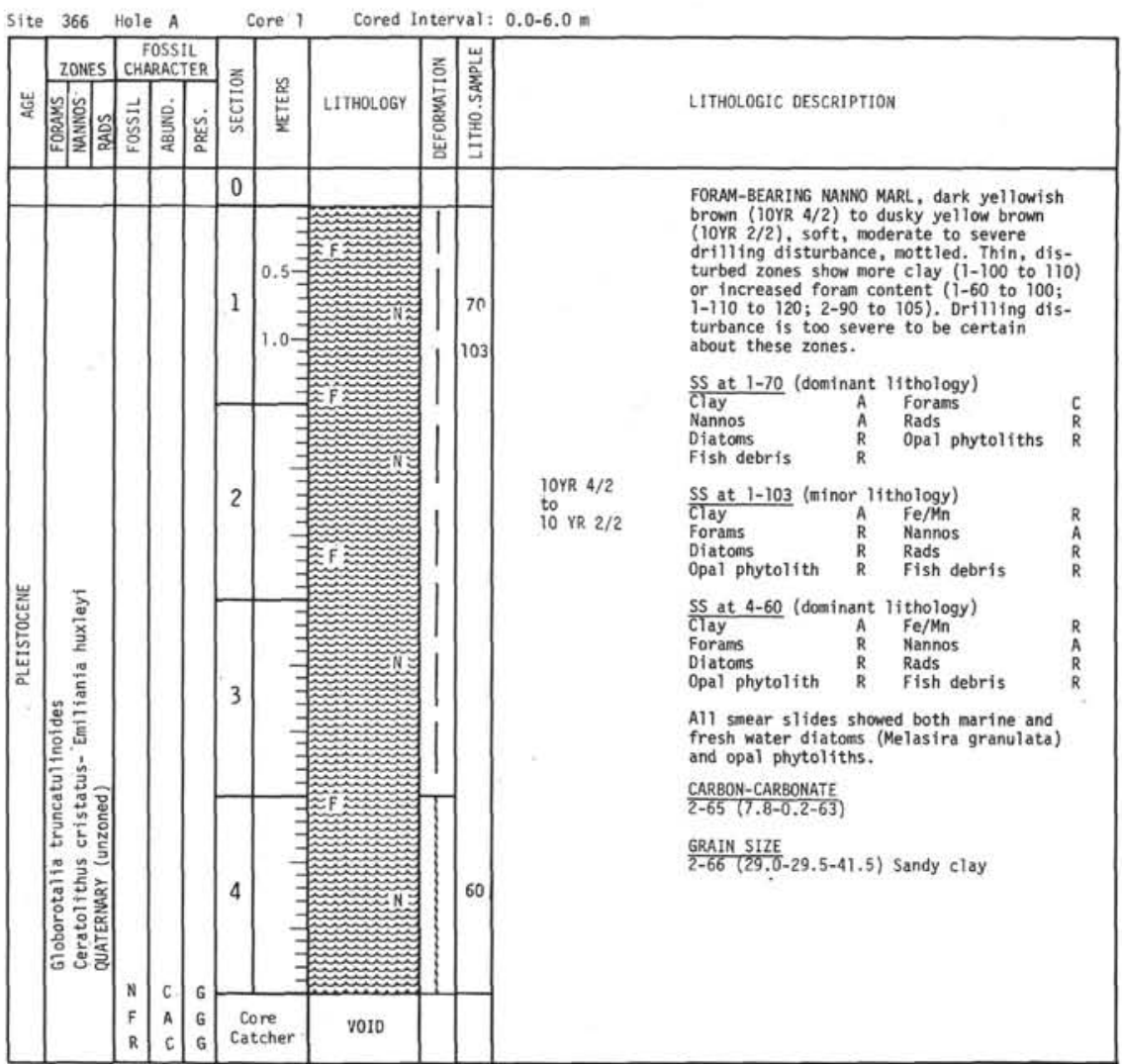

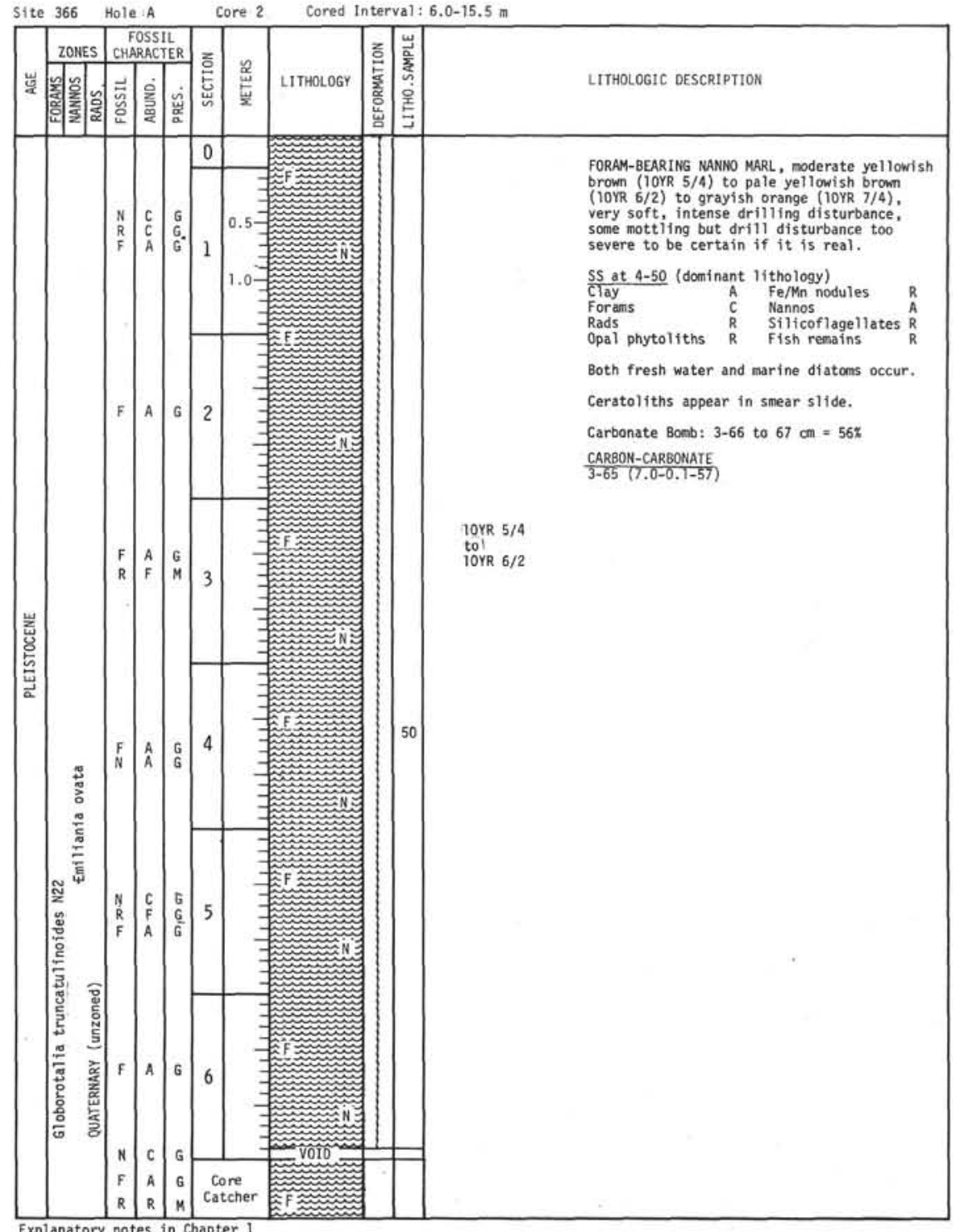



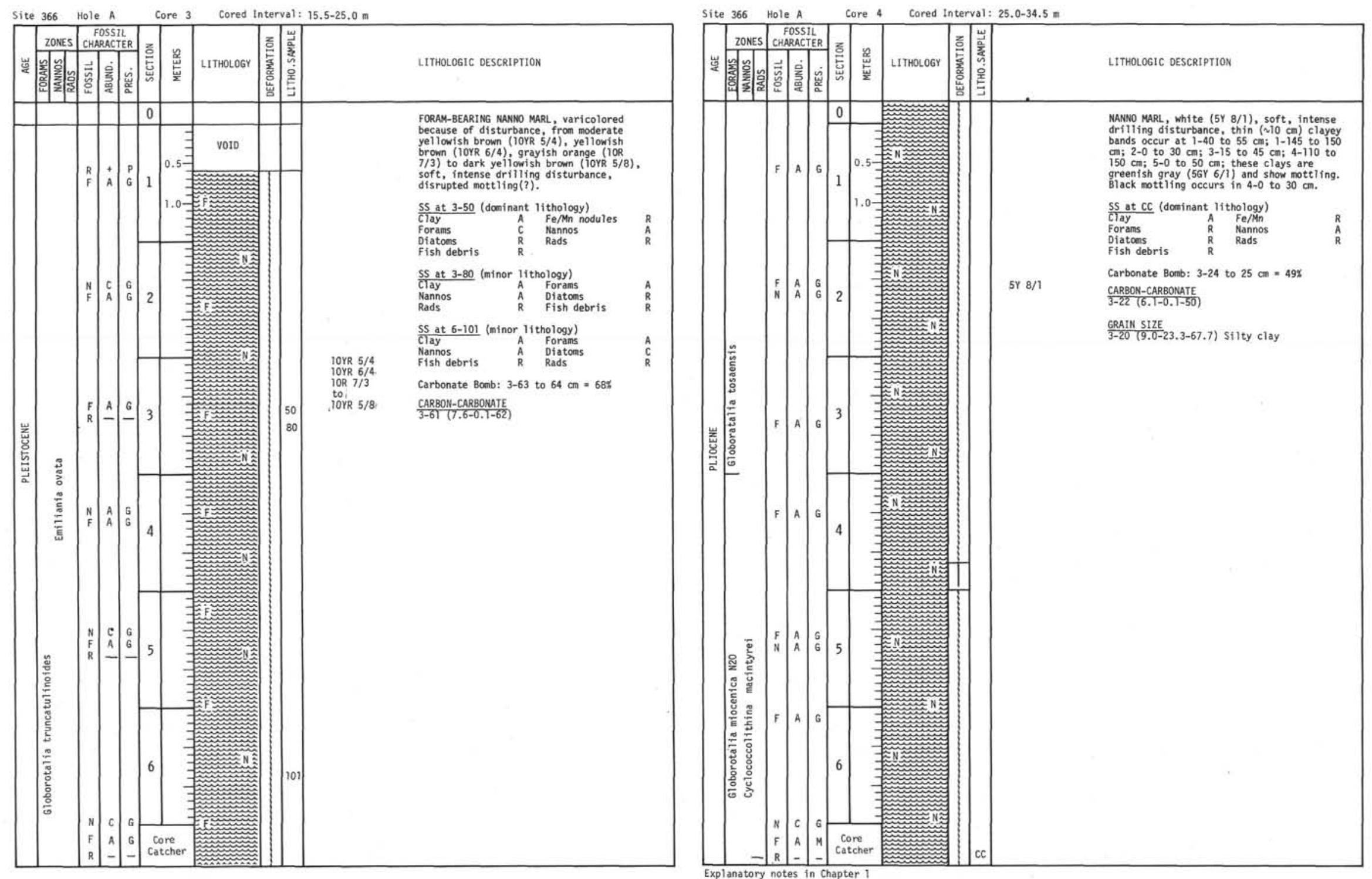


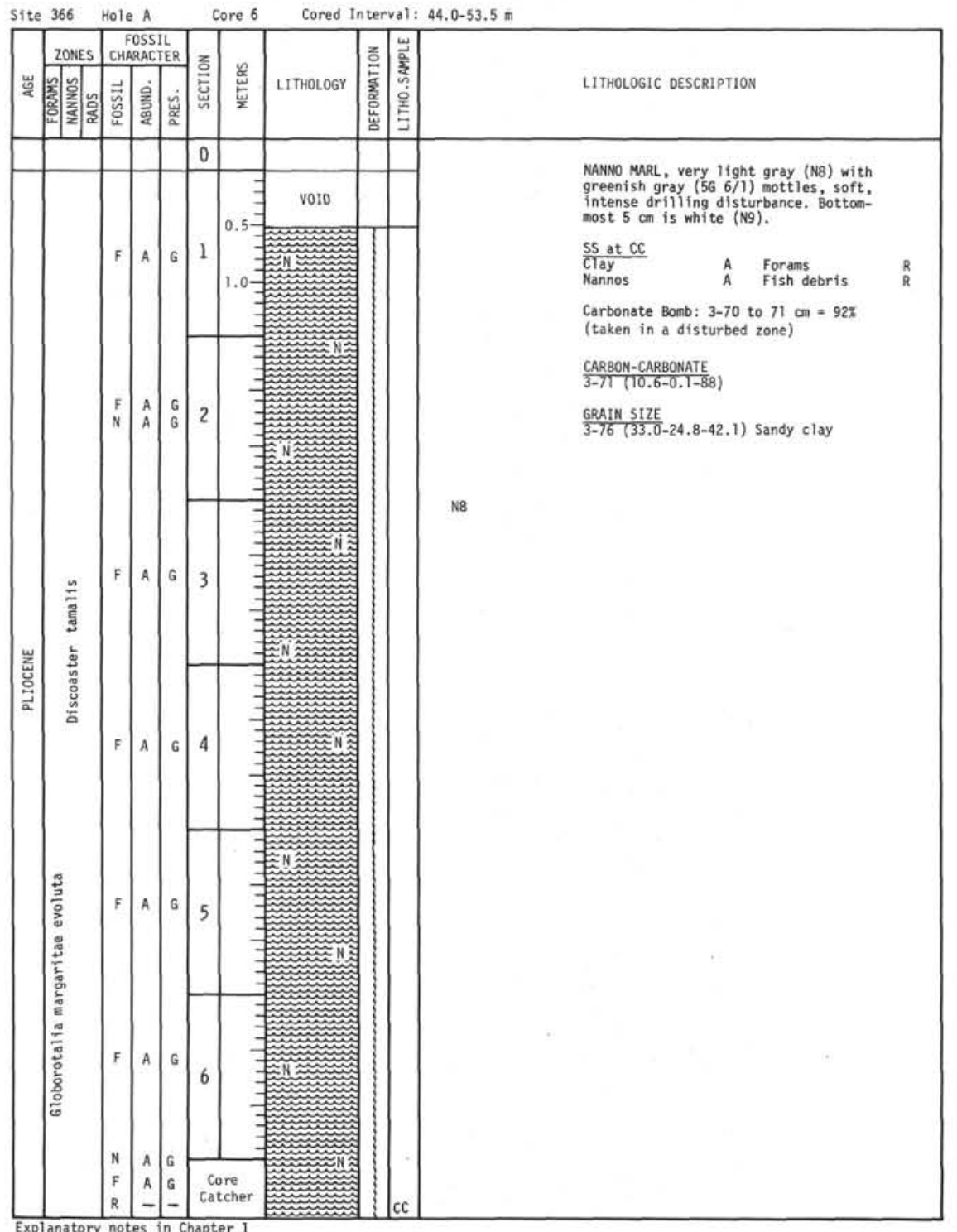



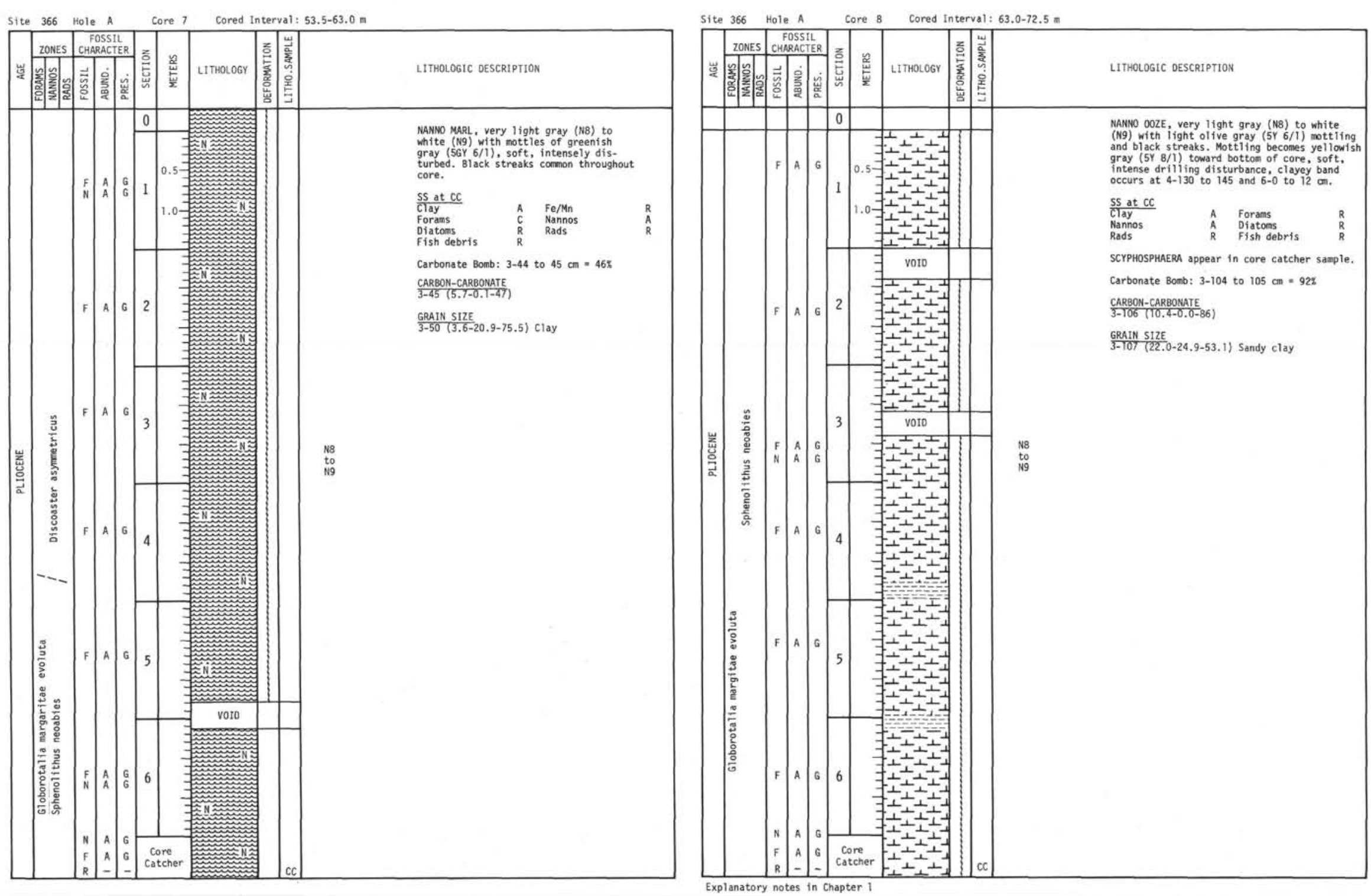


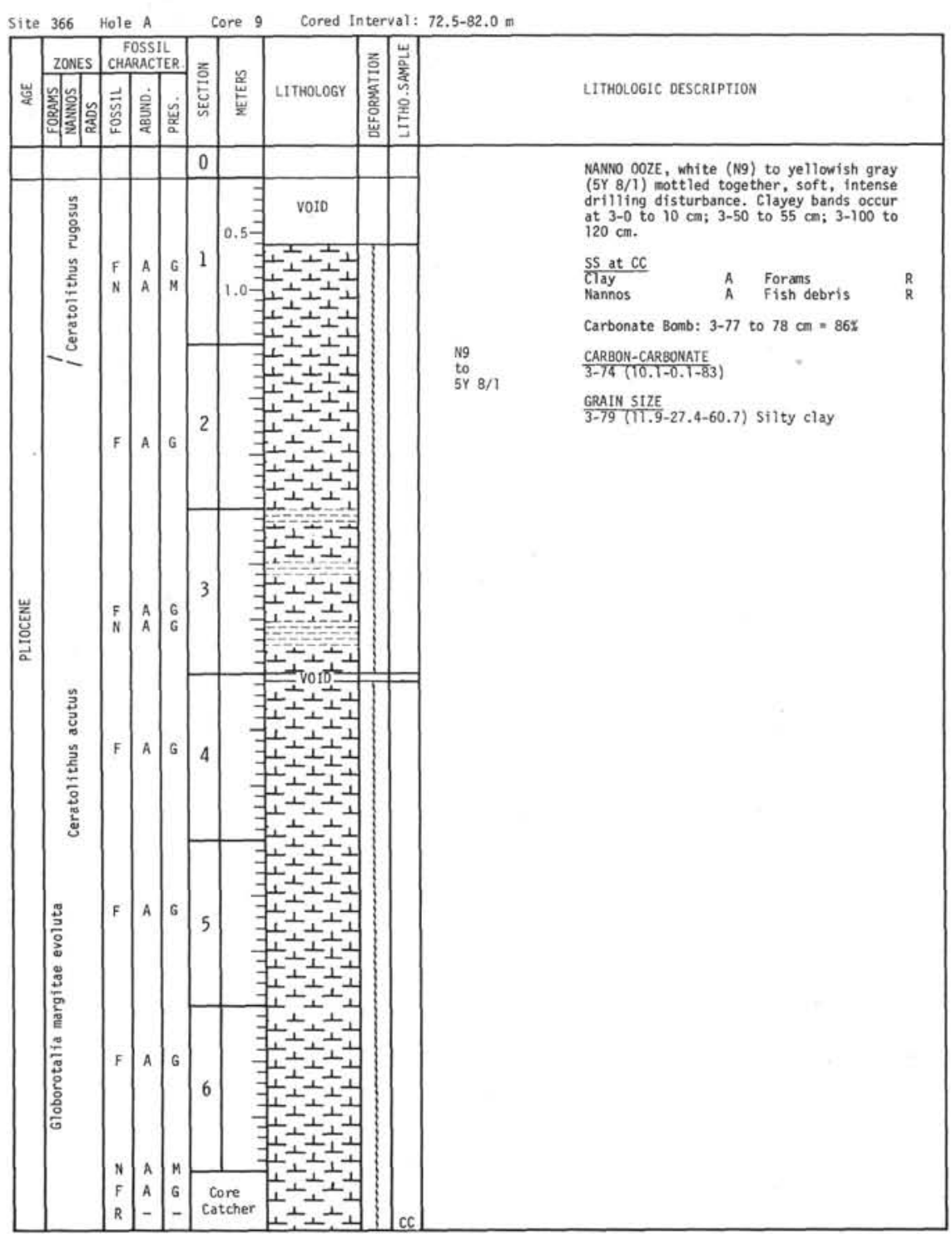

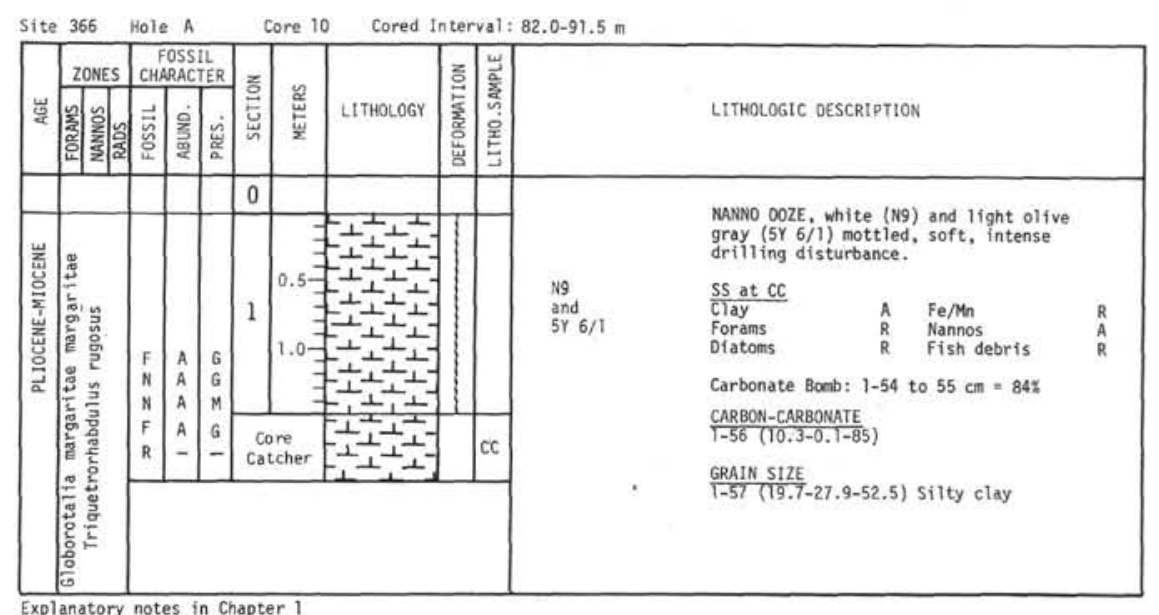

Explanatory notes in Chapter 1 

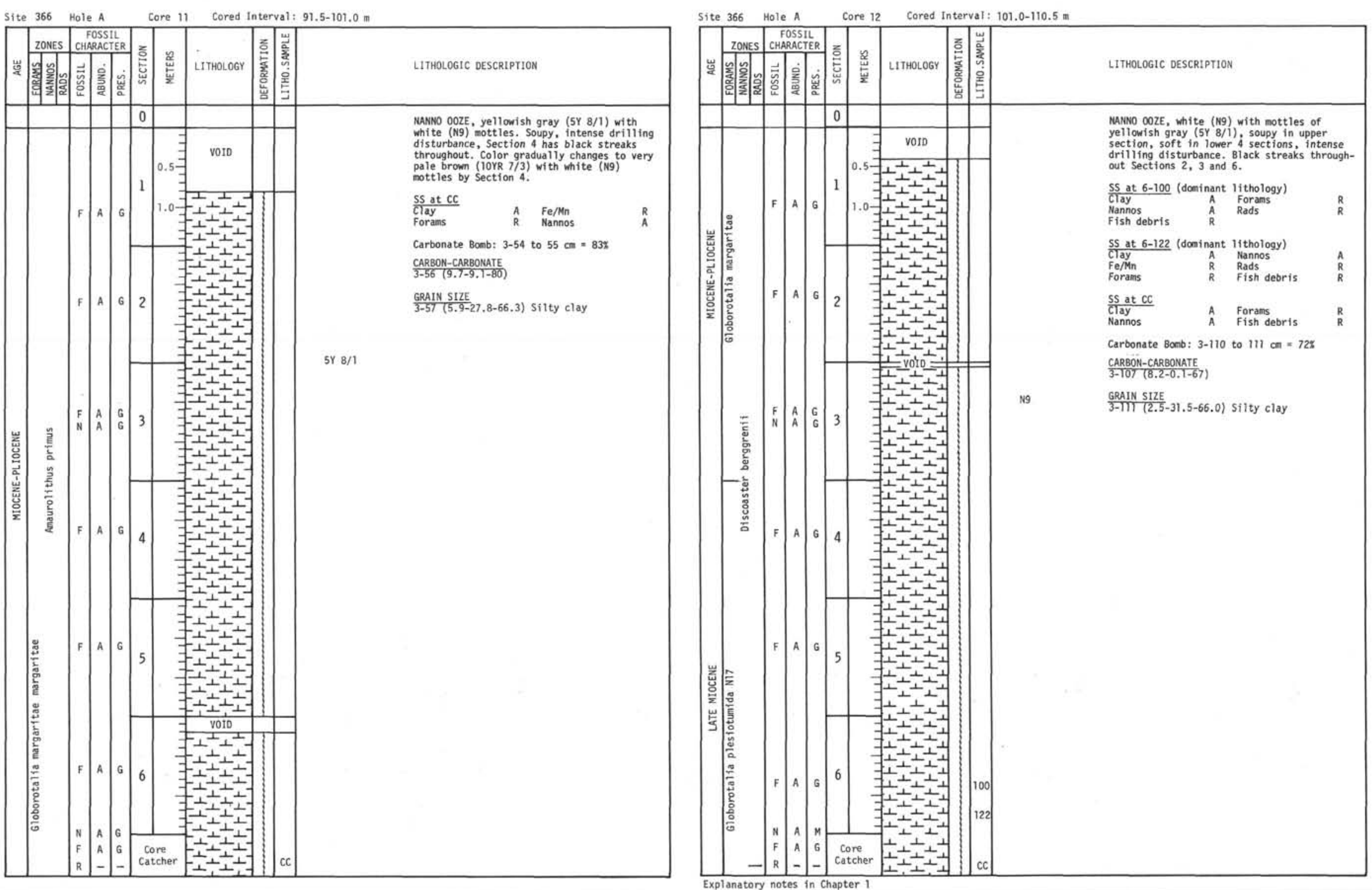


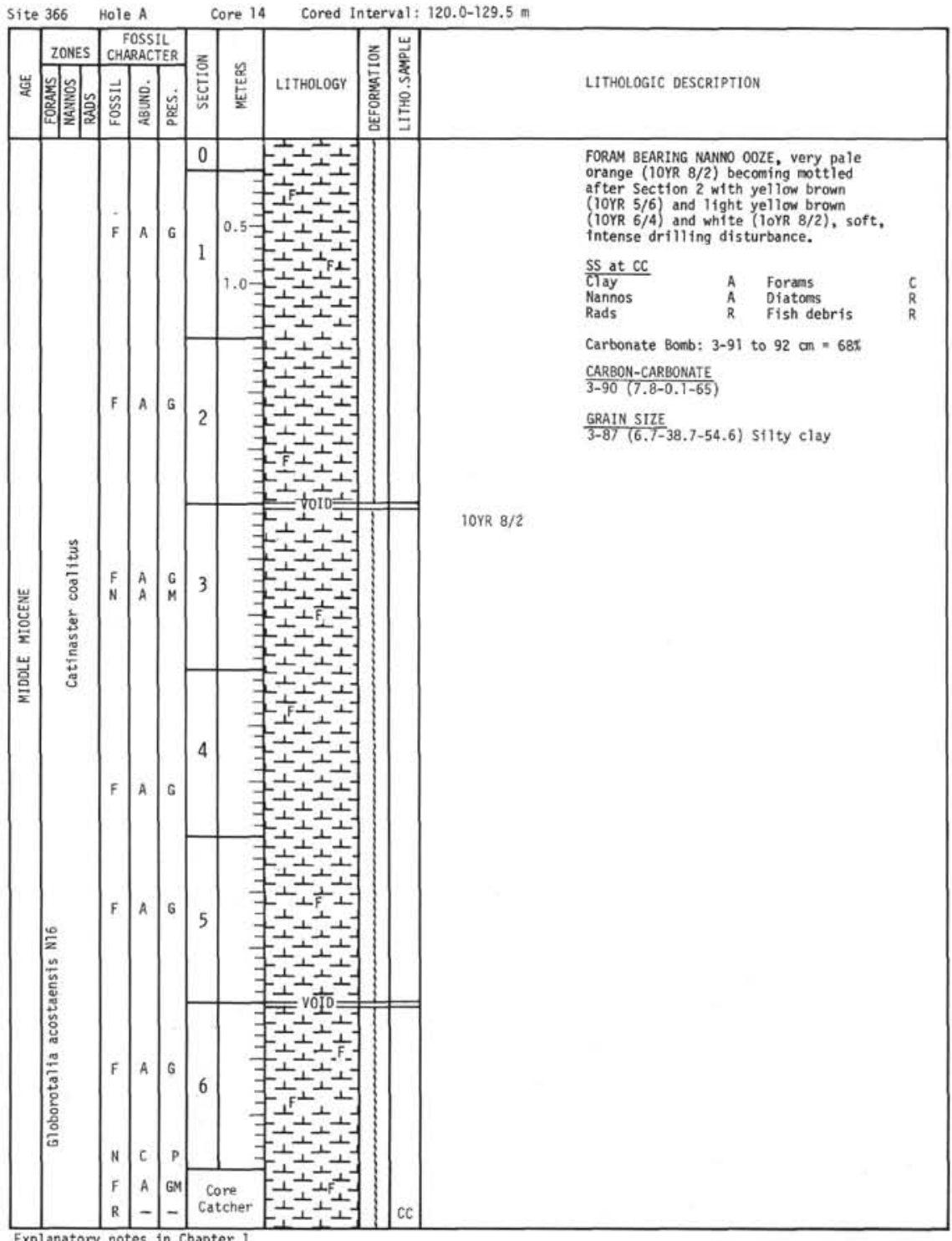




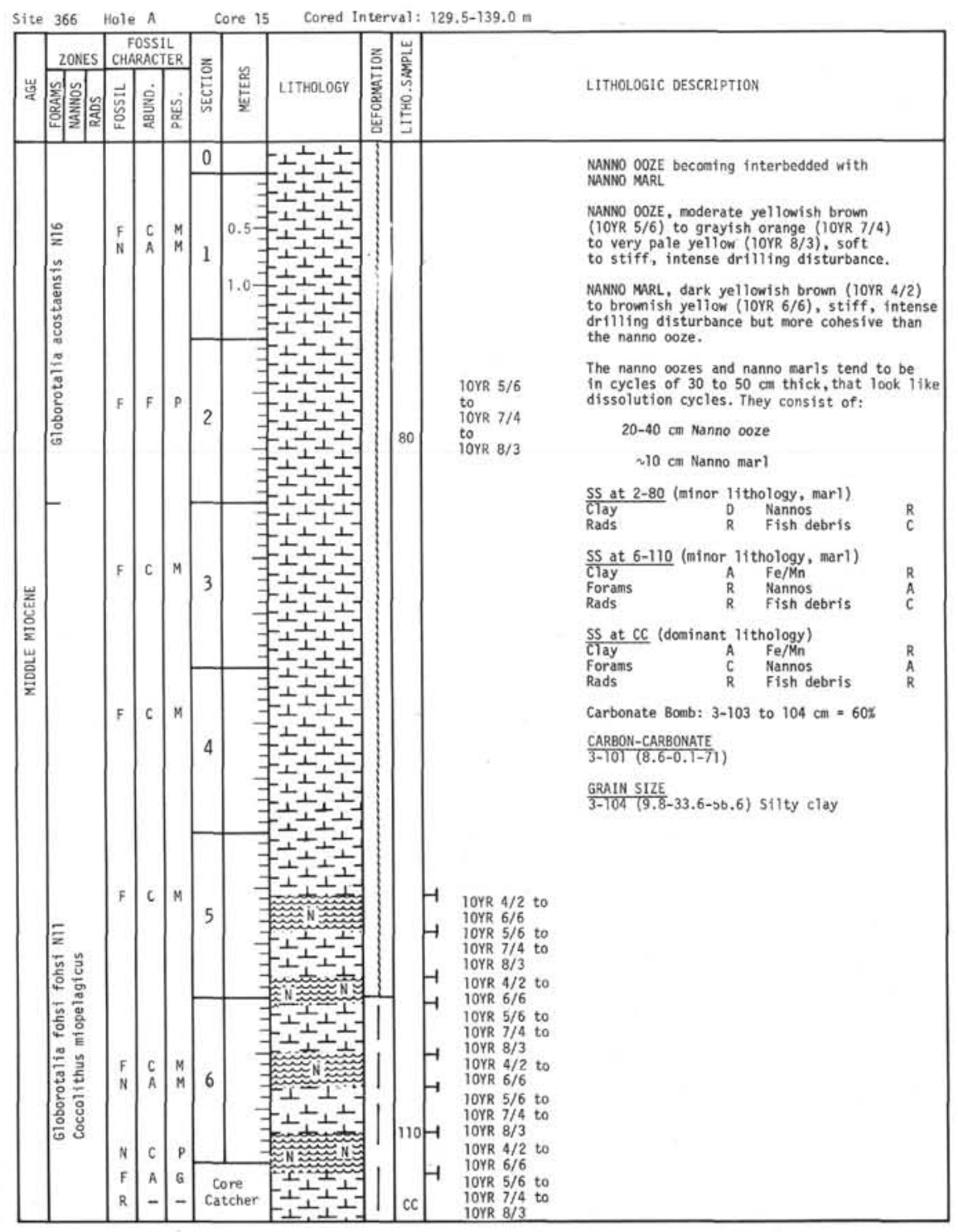

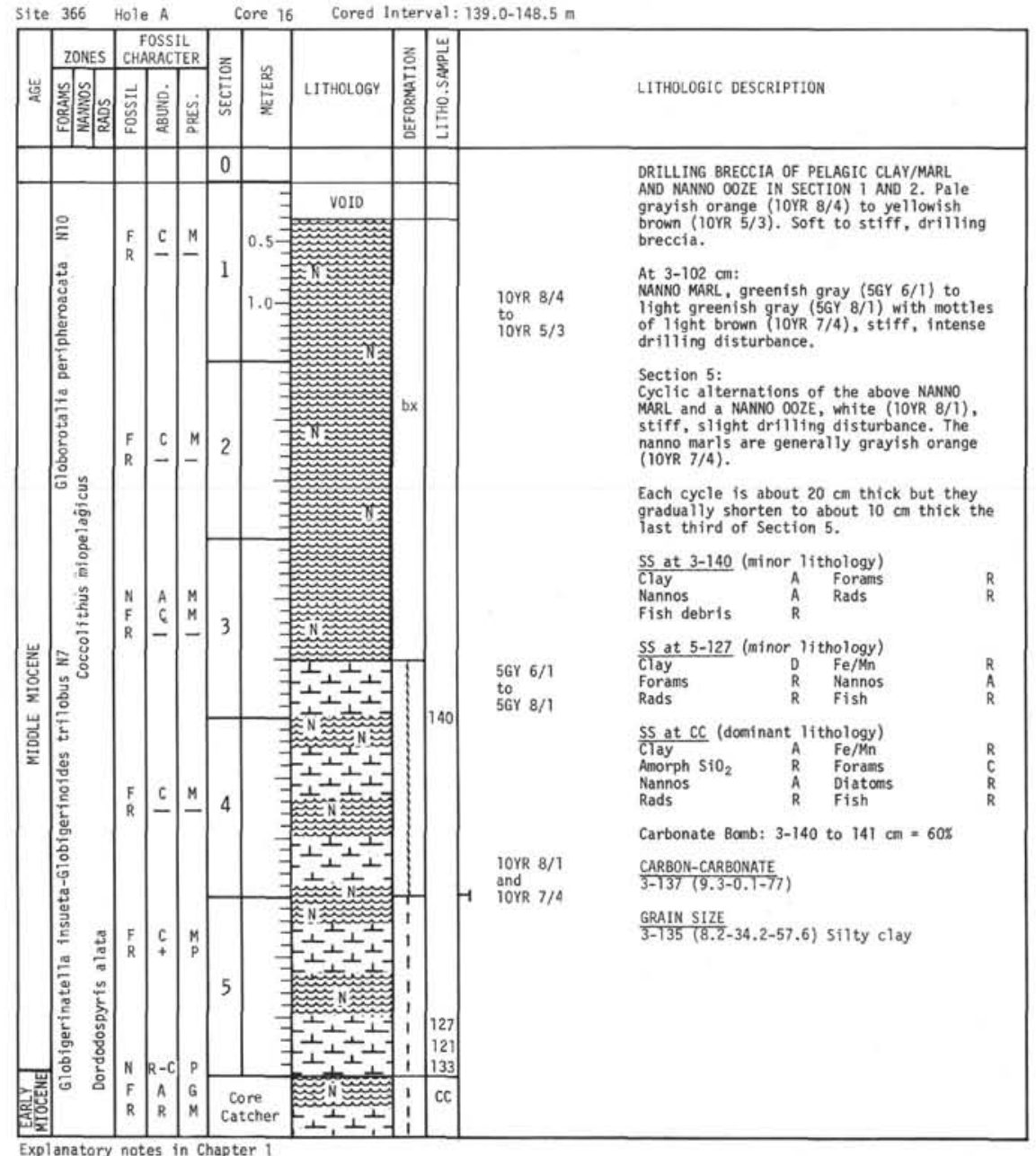




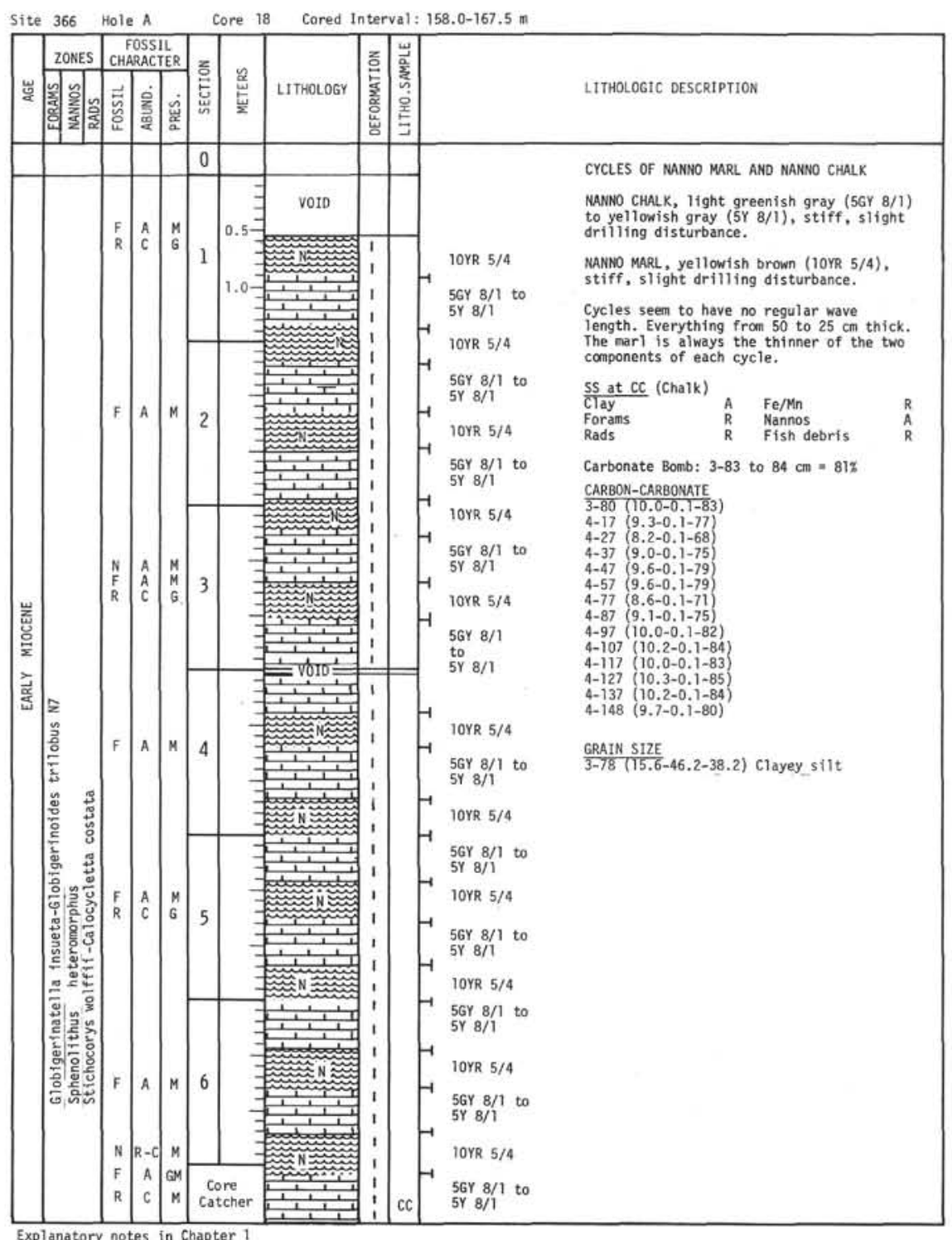


Site 366, Hole A, Core 19, Cored Interval: 167.5-177. 0 m: NO RE COVERY

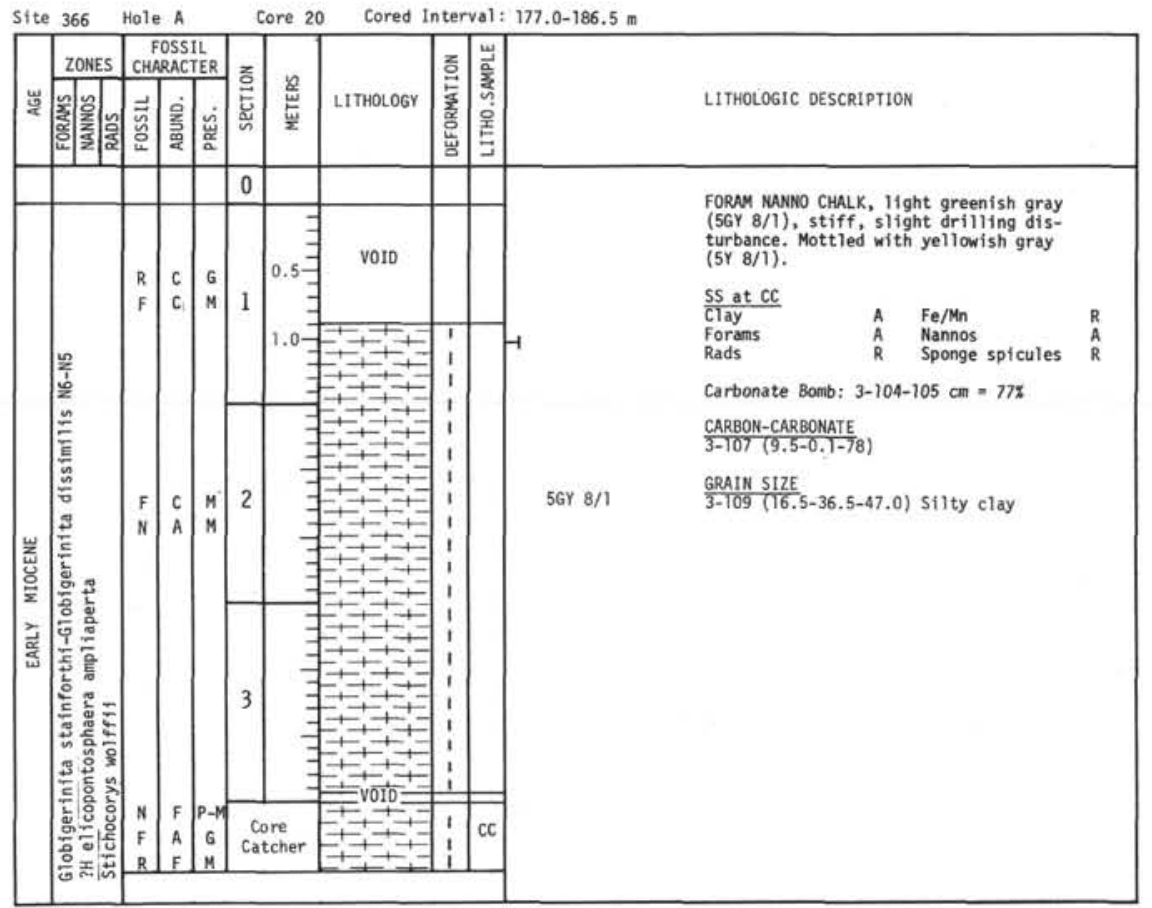

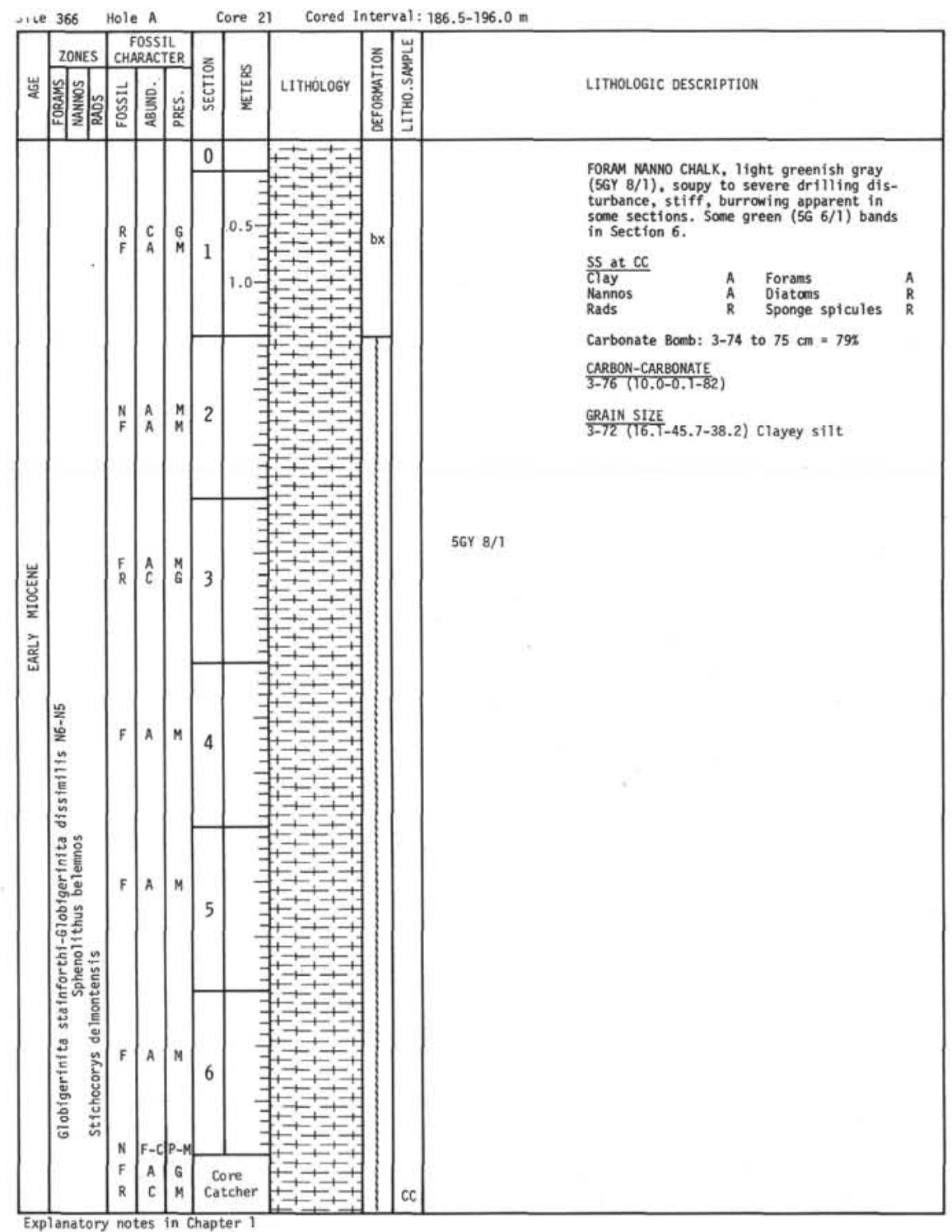




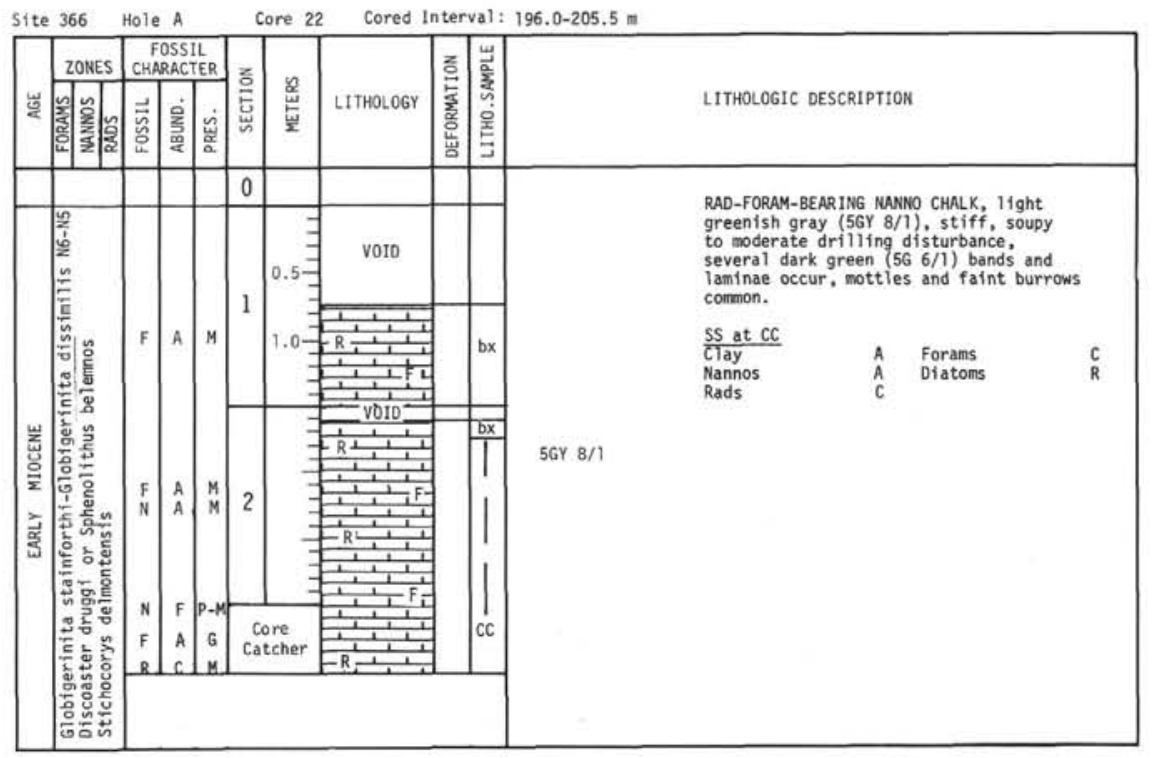

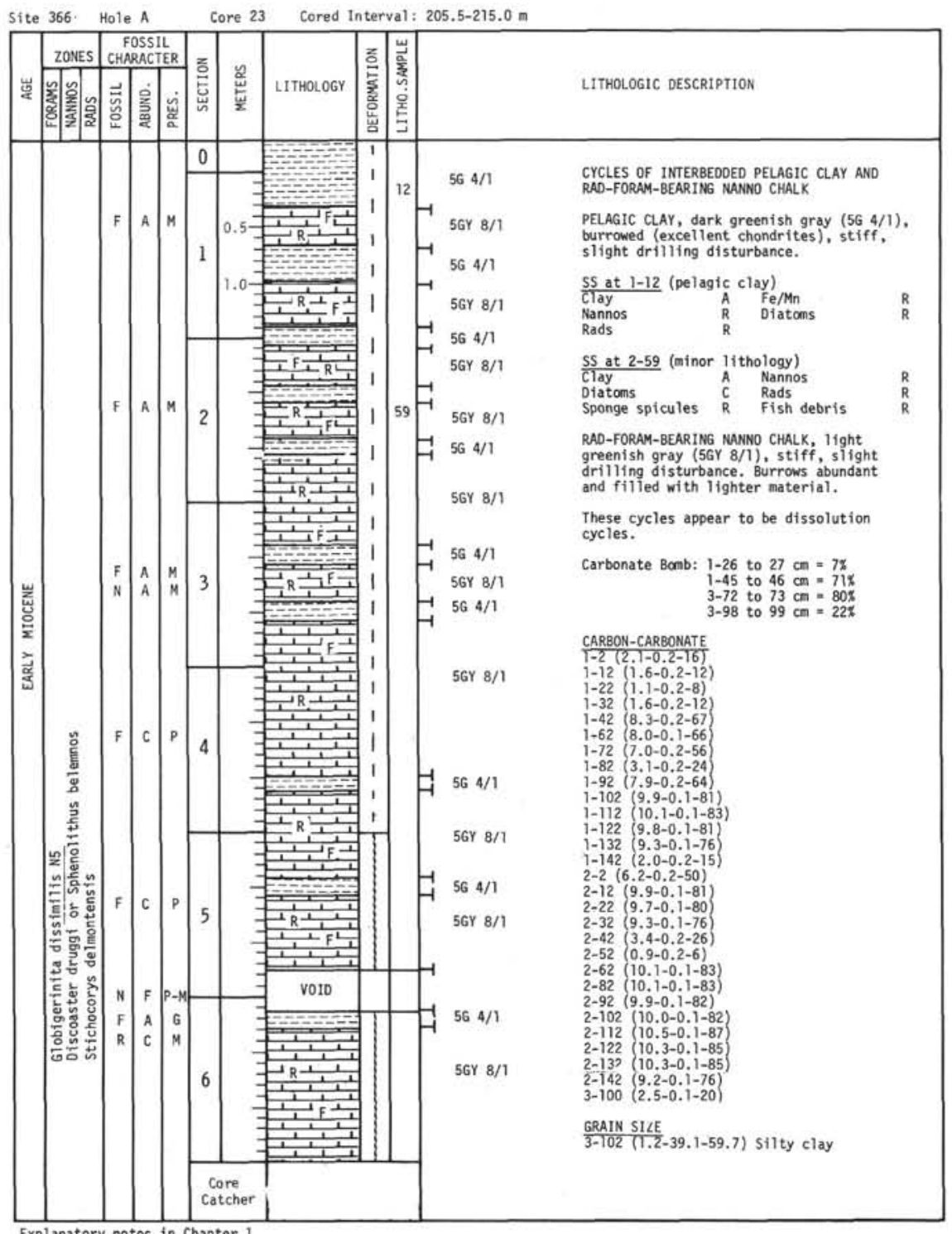


Site 366 Hole A Core 24 Cored Interval: $215.0-224.5 \mathrm{~m}$

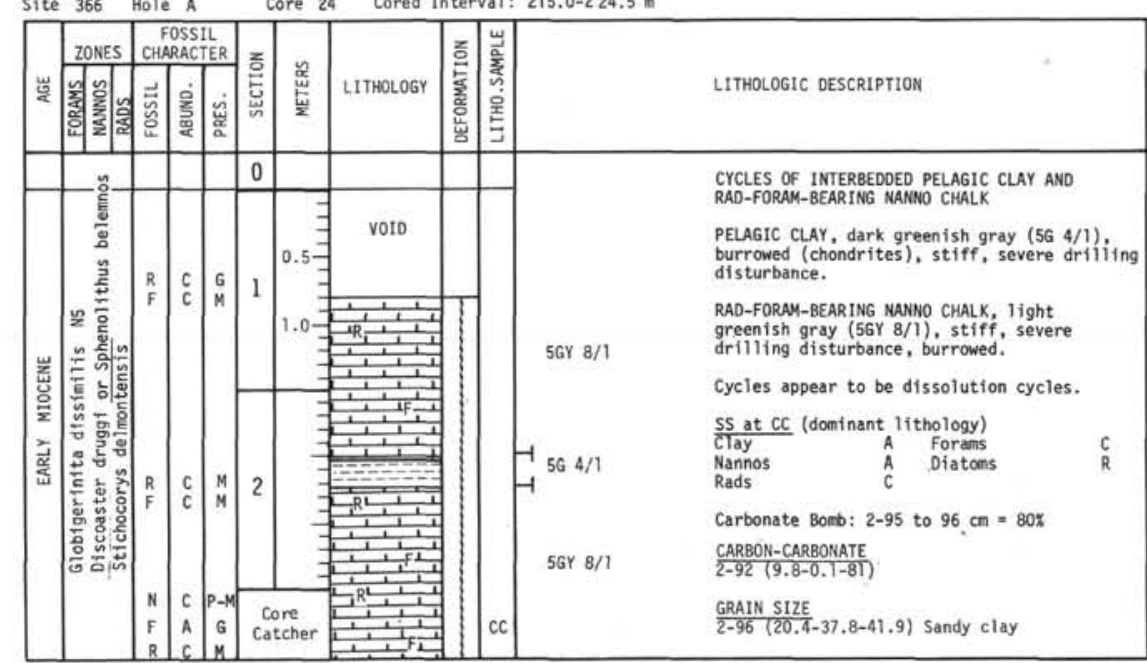

\begin{tabular}{l} 
Site 366 Hole A \\
\begin{tabular}{|l|l|l|l|l|l|l|l|l|l|}
\hline & Core 25 & Cored Interval: $224.5-234.0 \mathrm{~m}$ \\
\hline
\end{tabular} \\
\hline
\end{tabular}

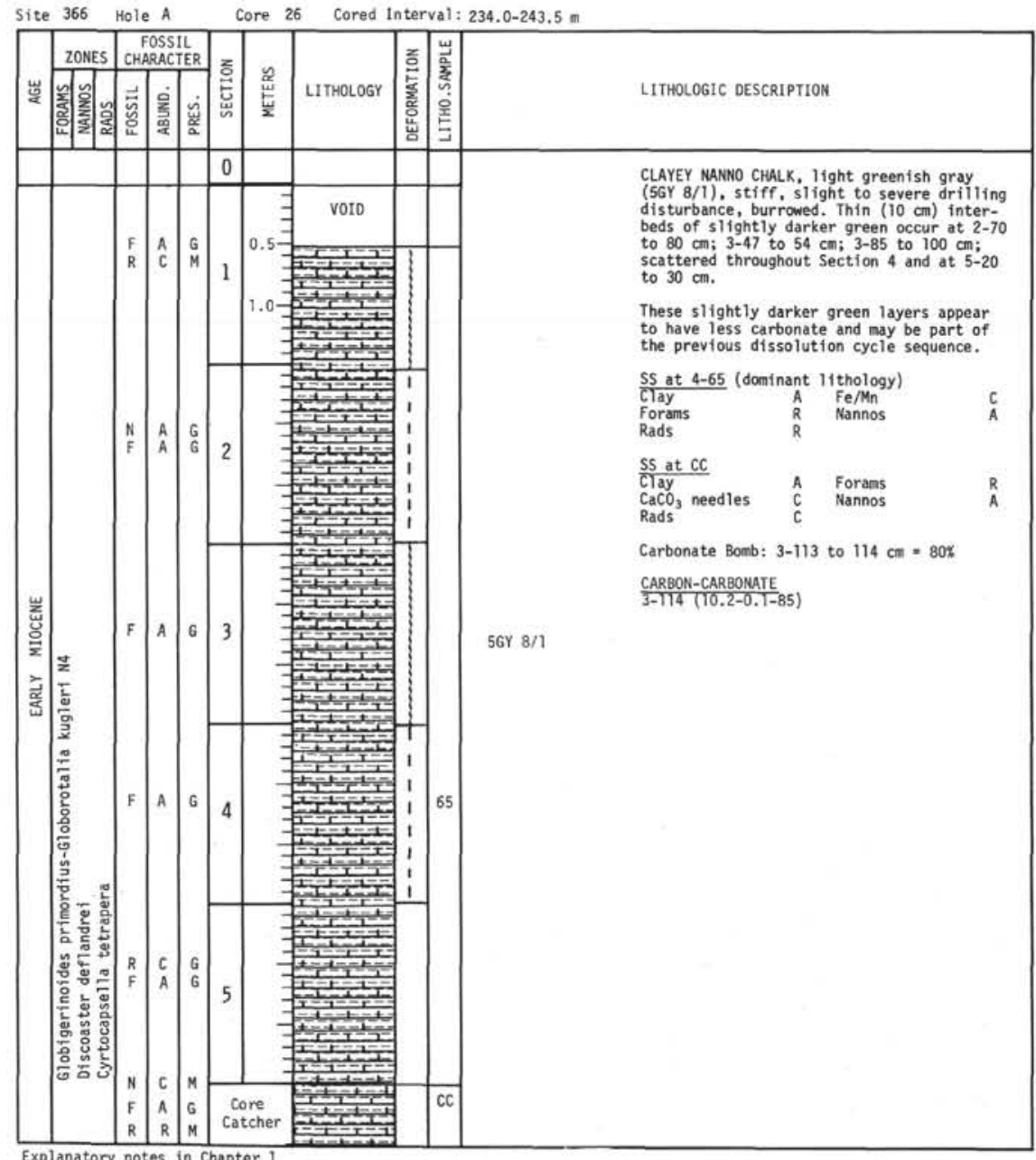

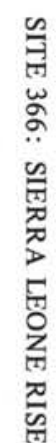




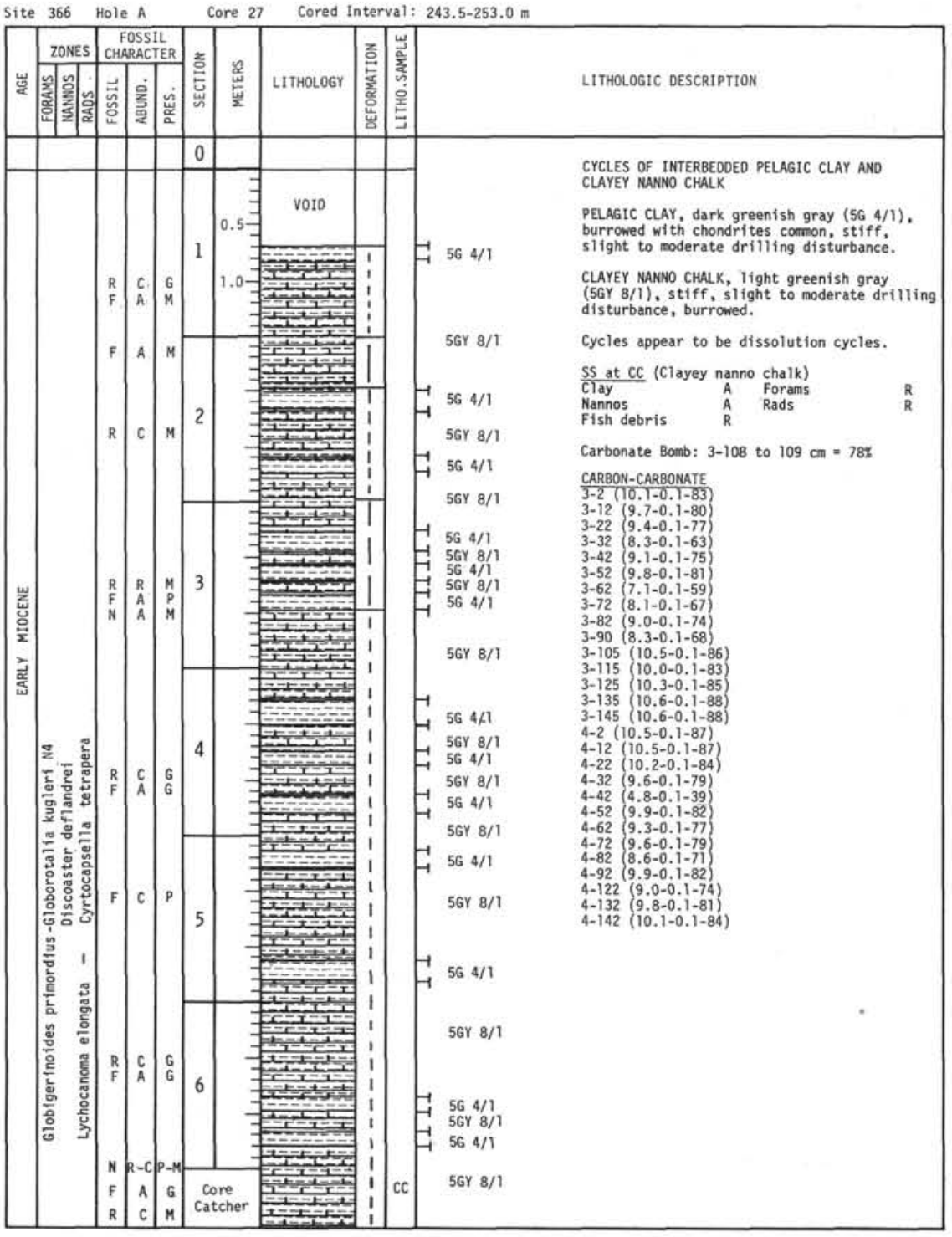

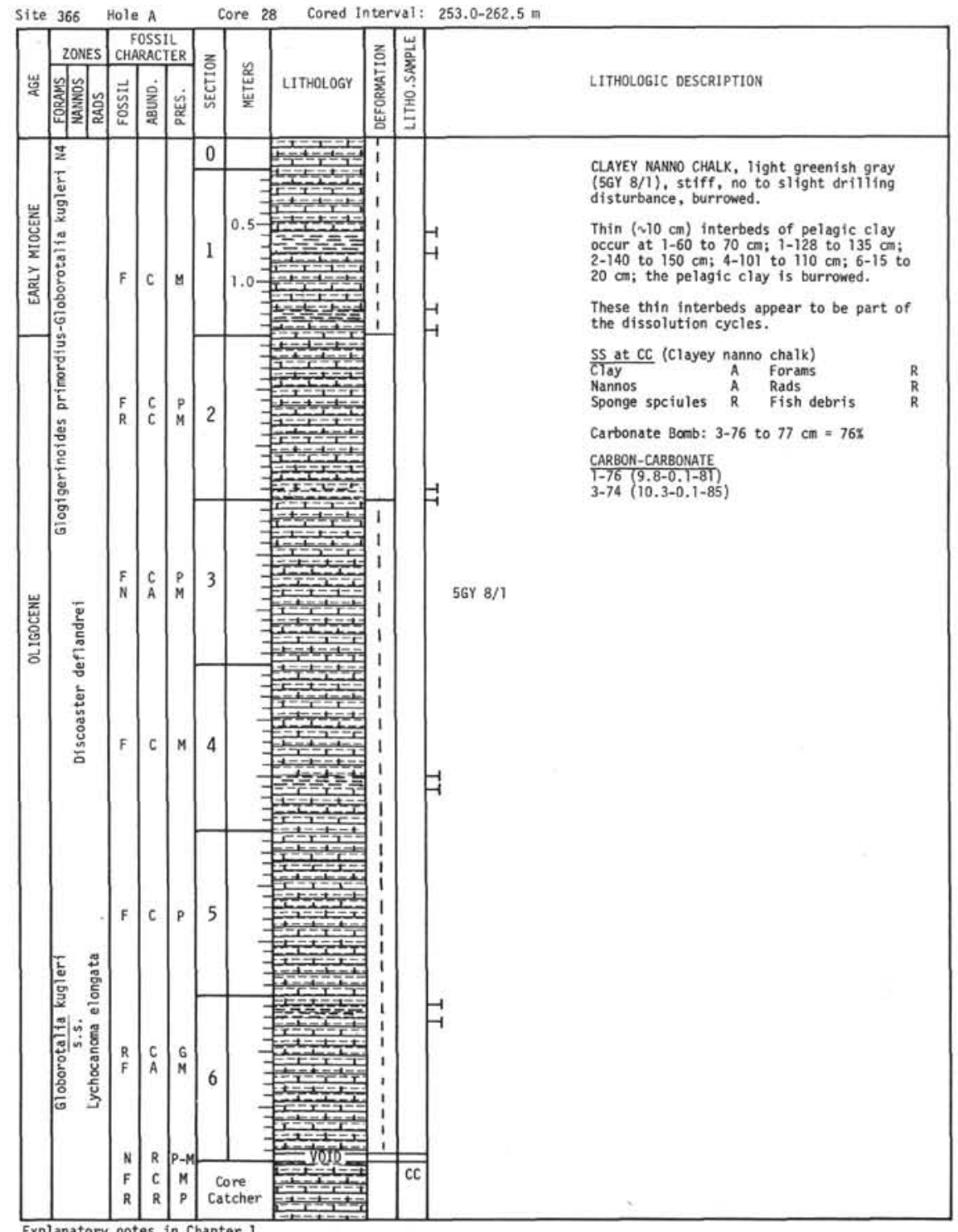



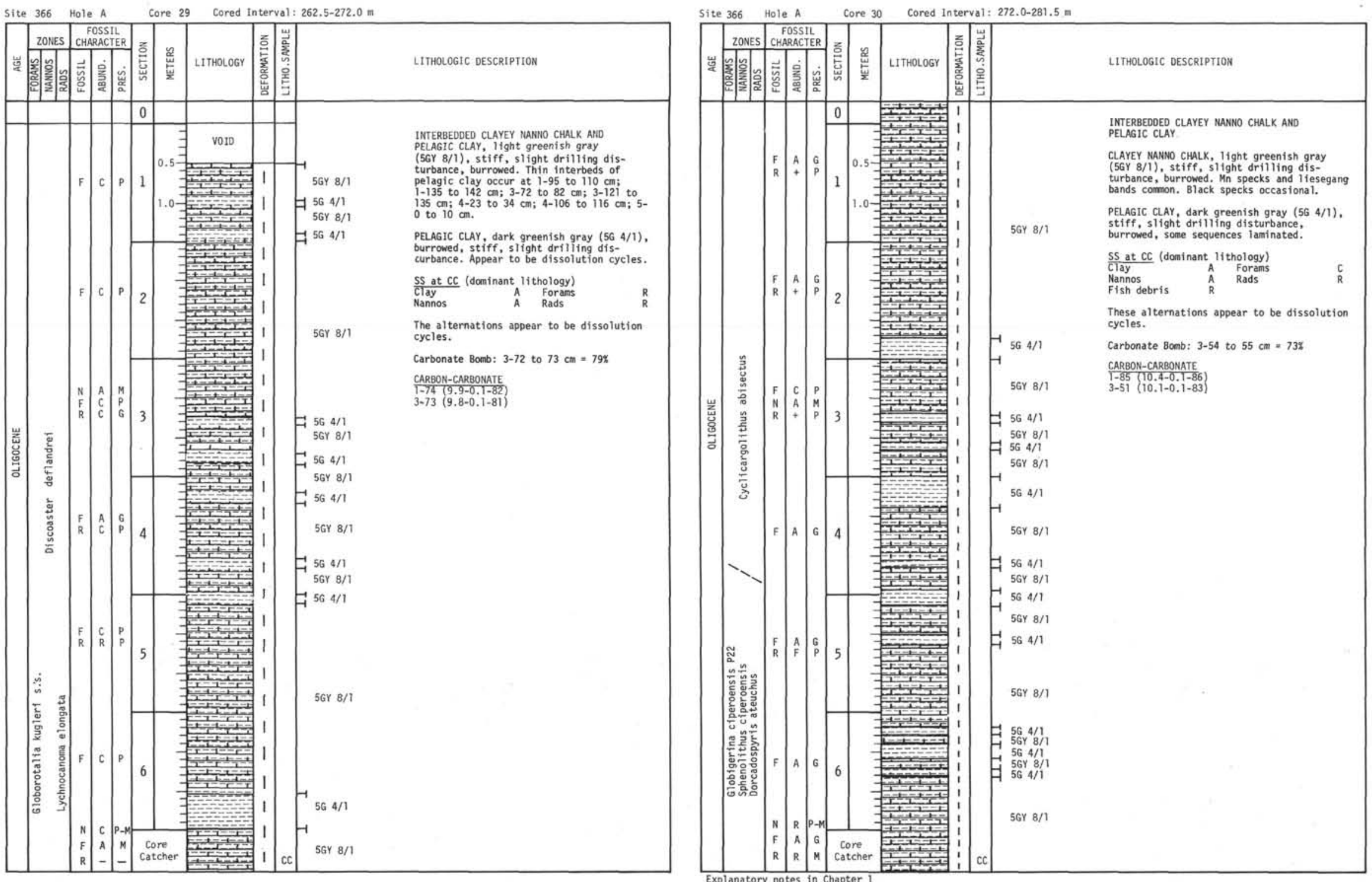


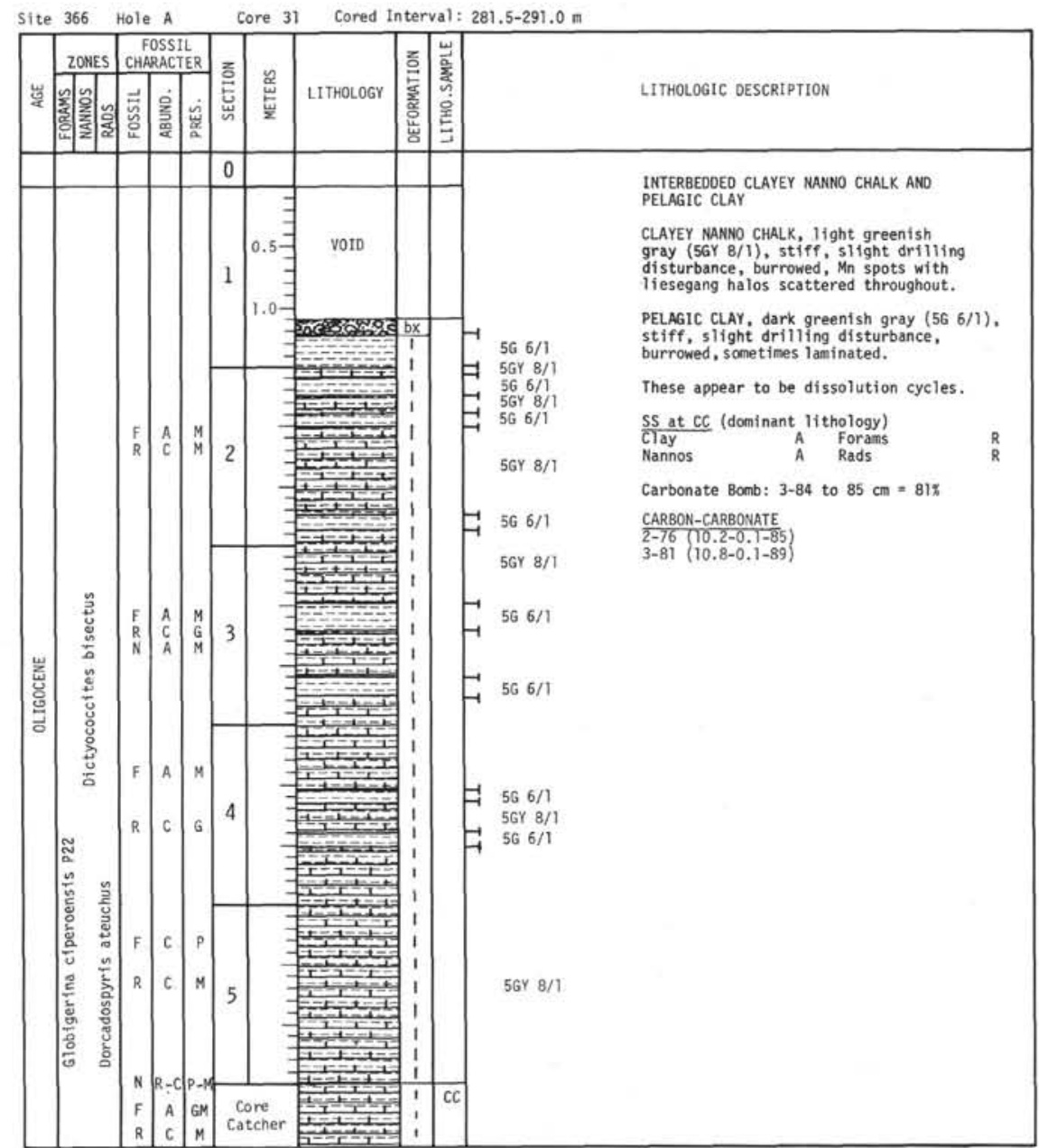

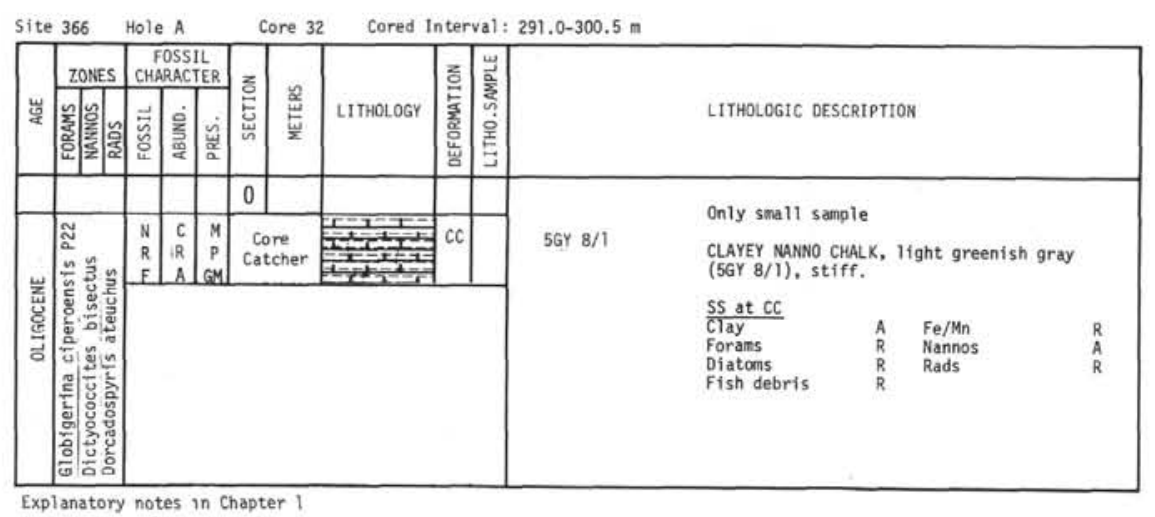




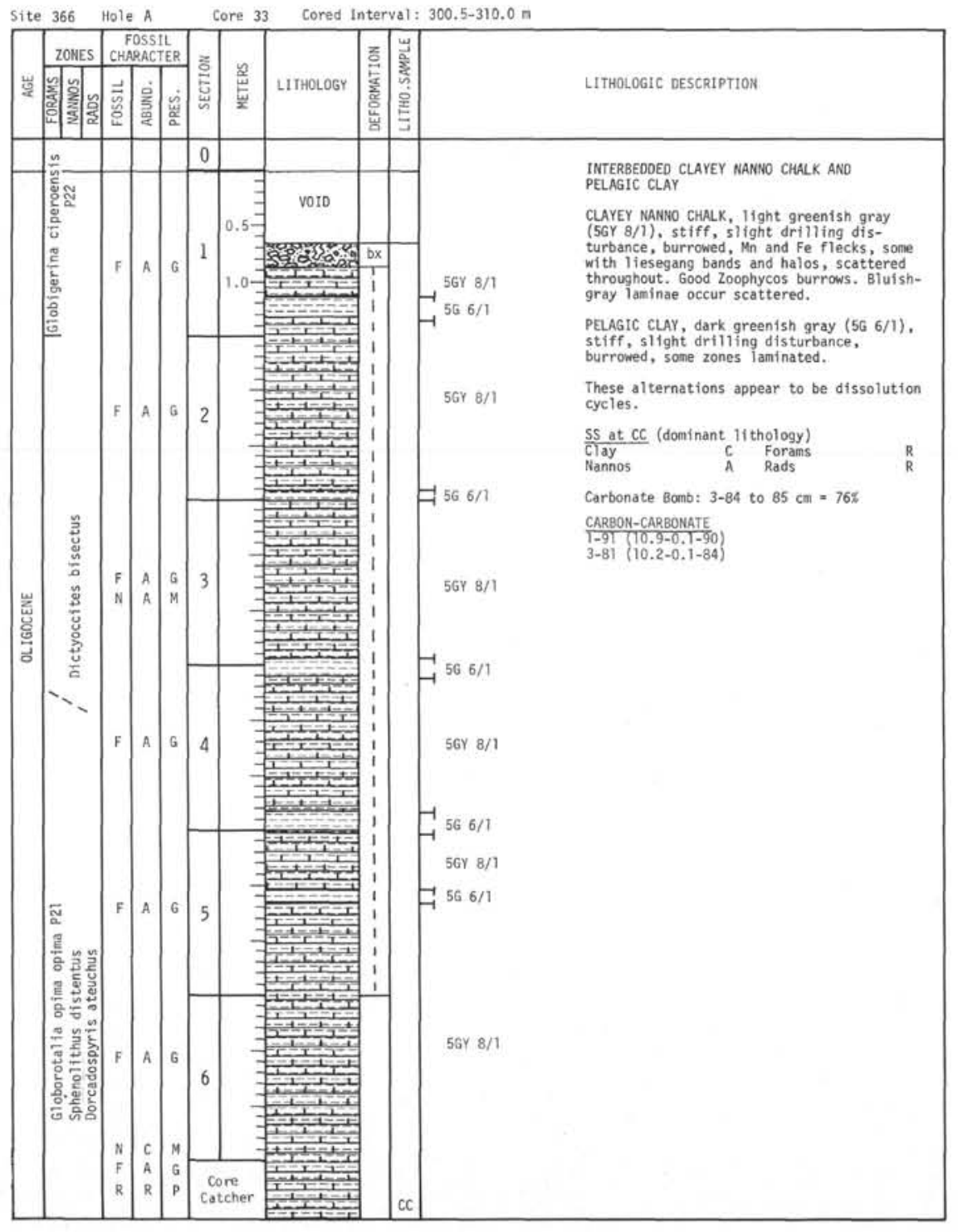

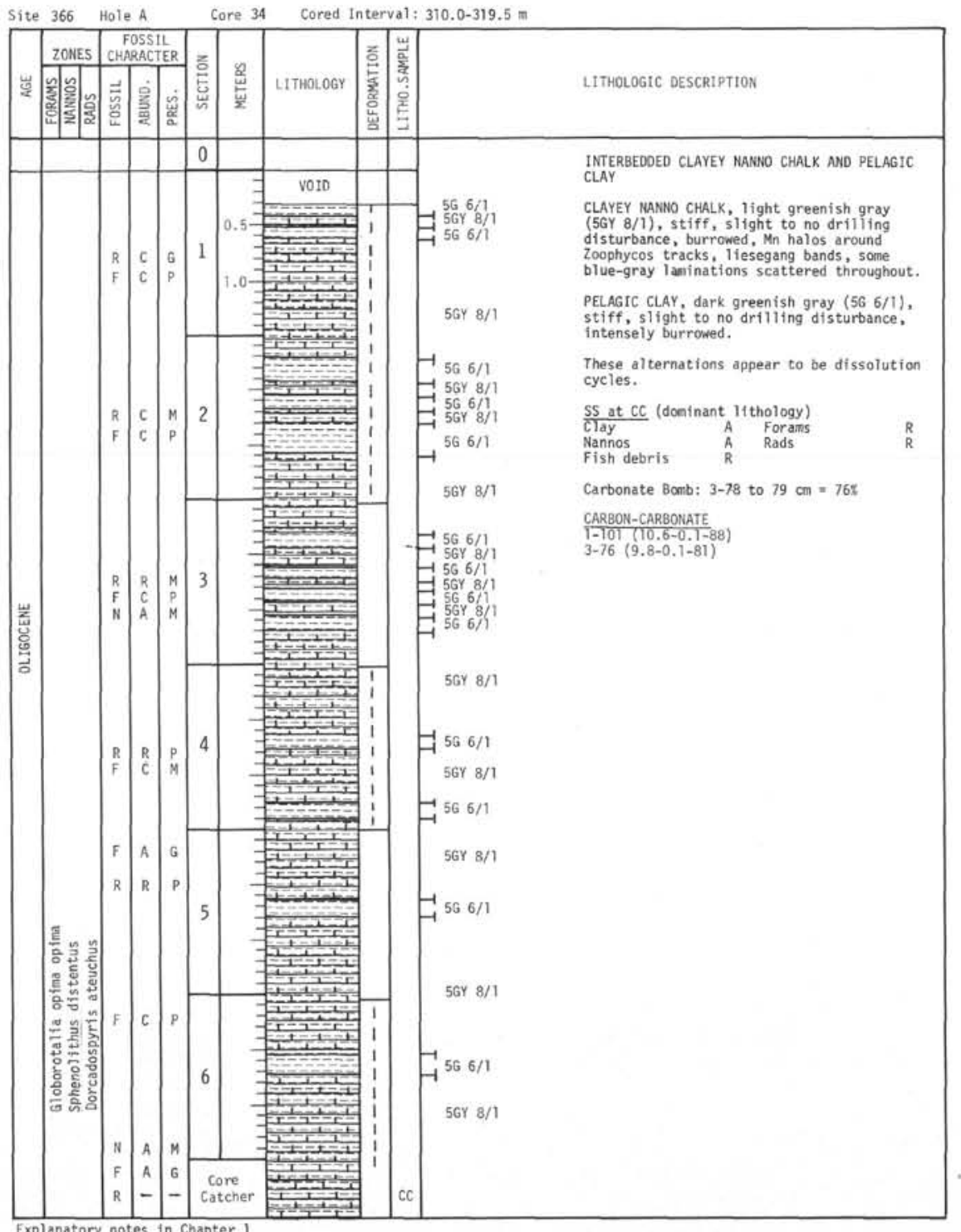




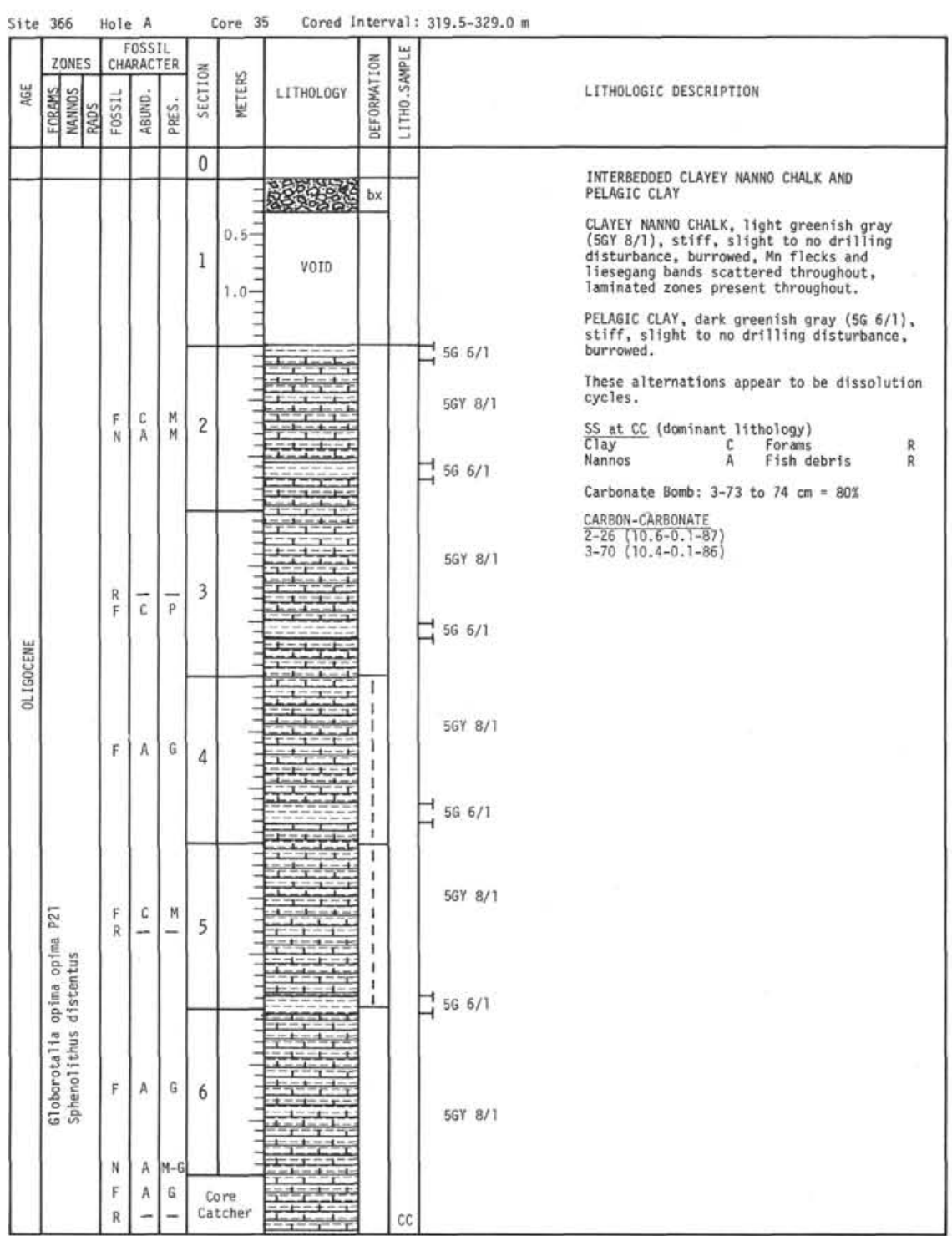

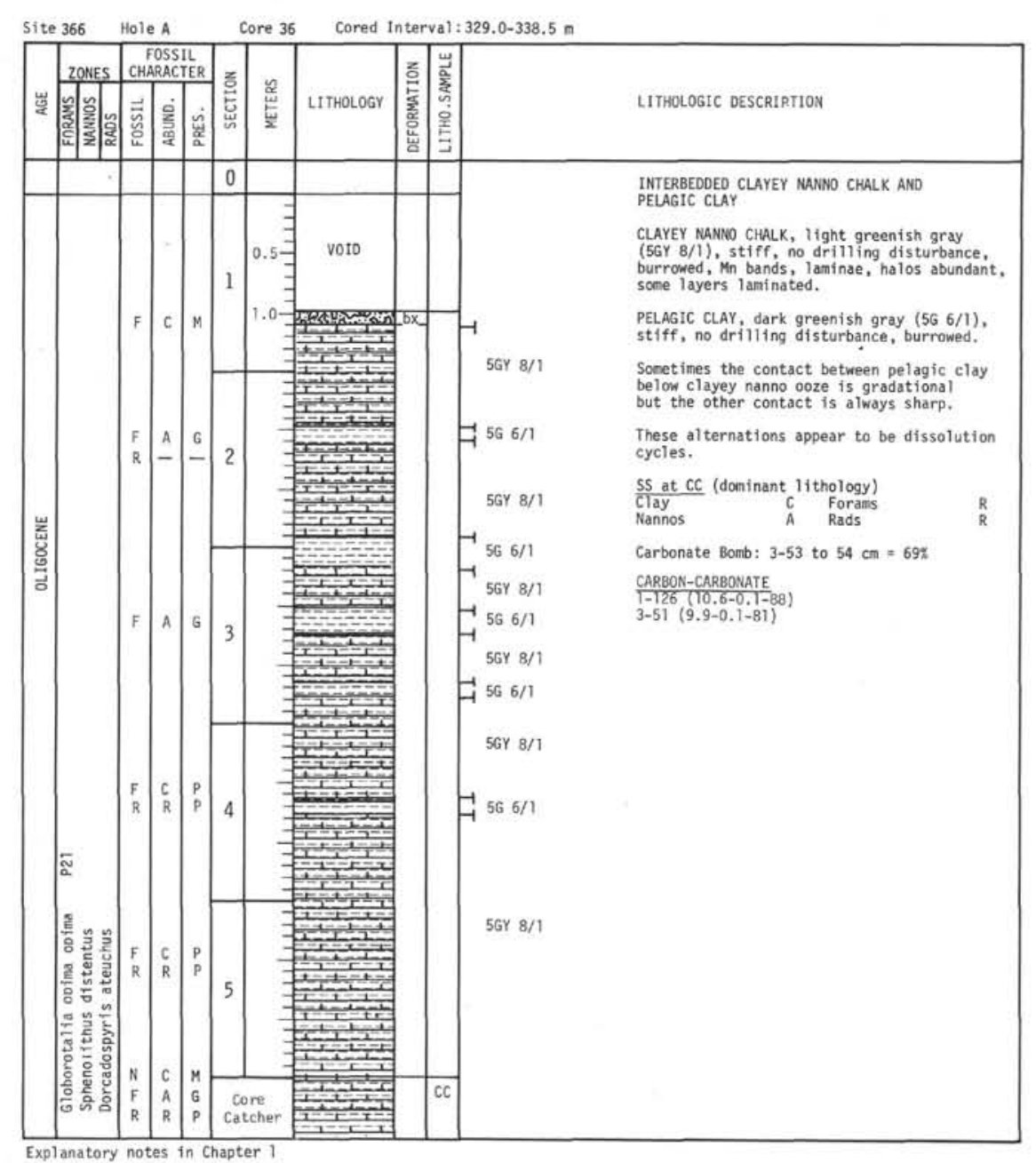




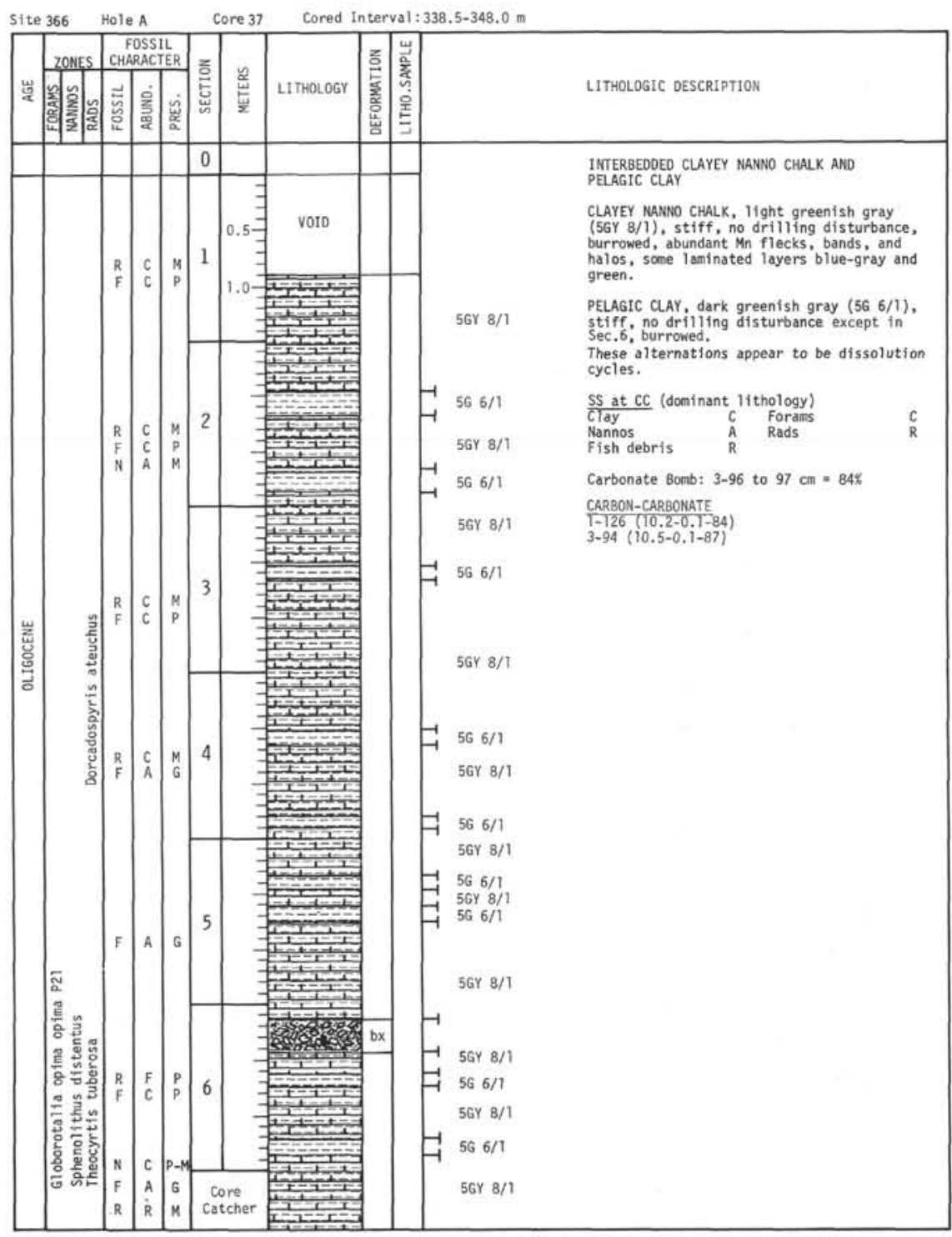

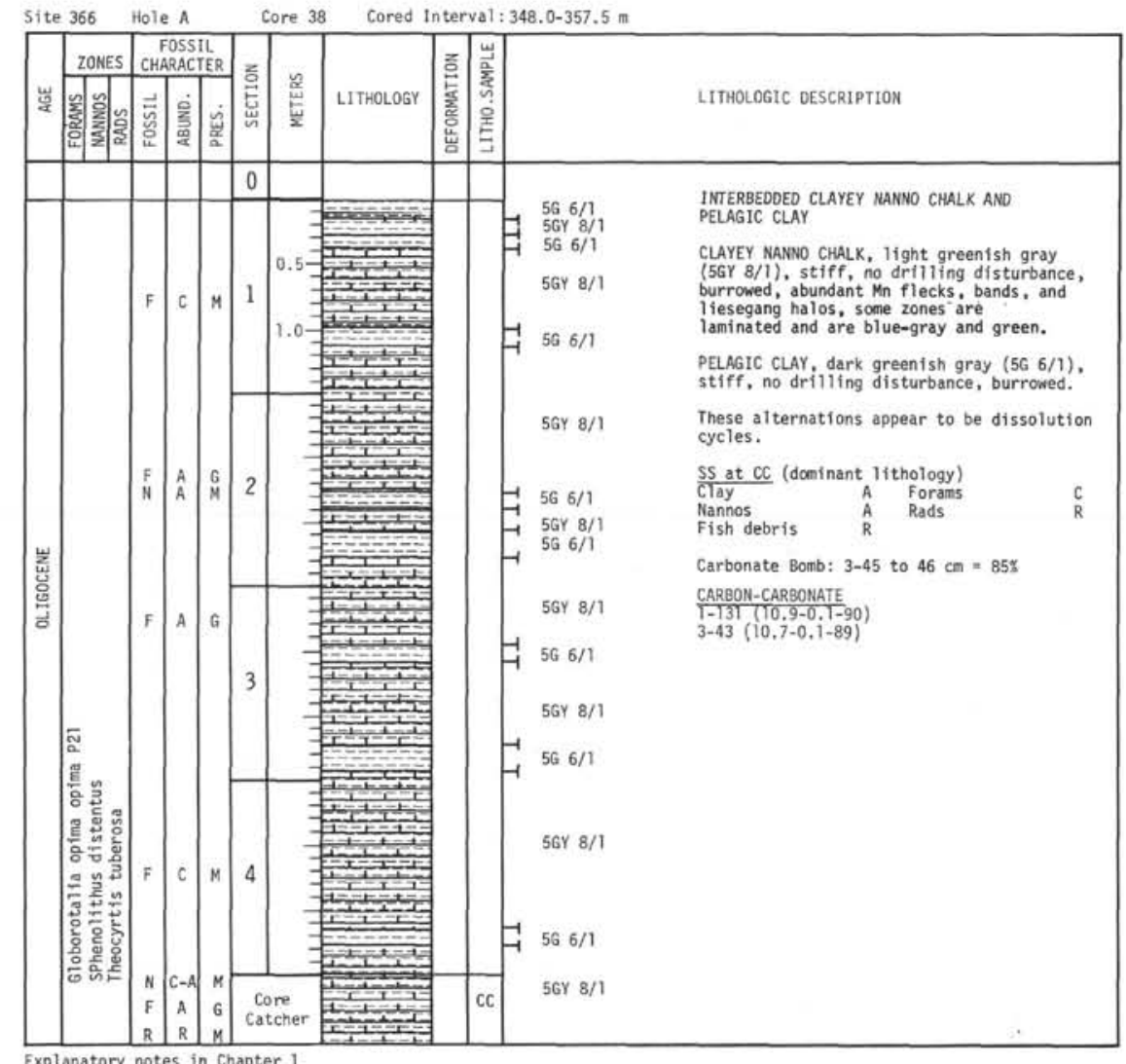




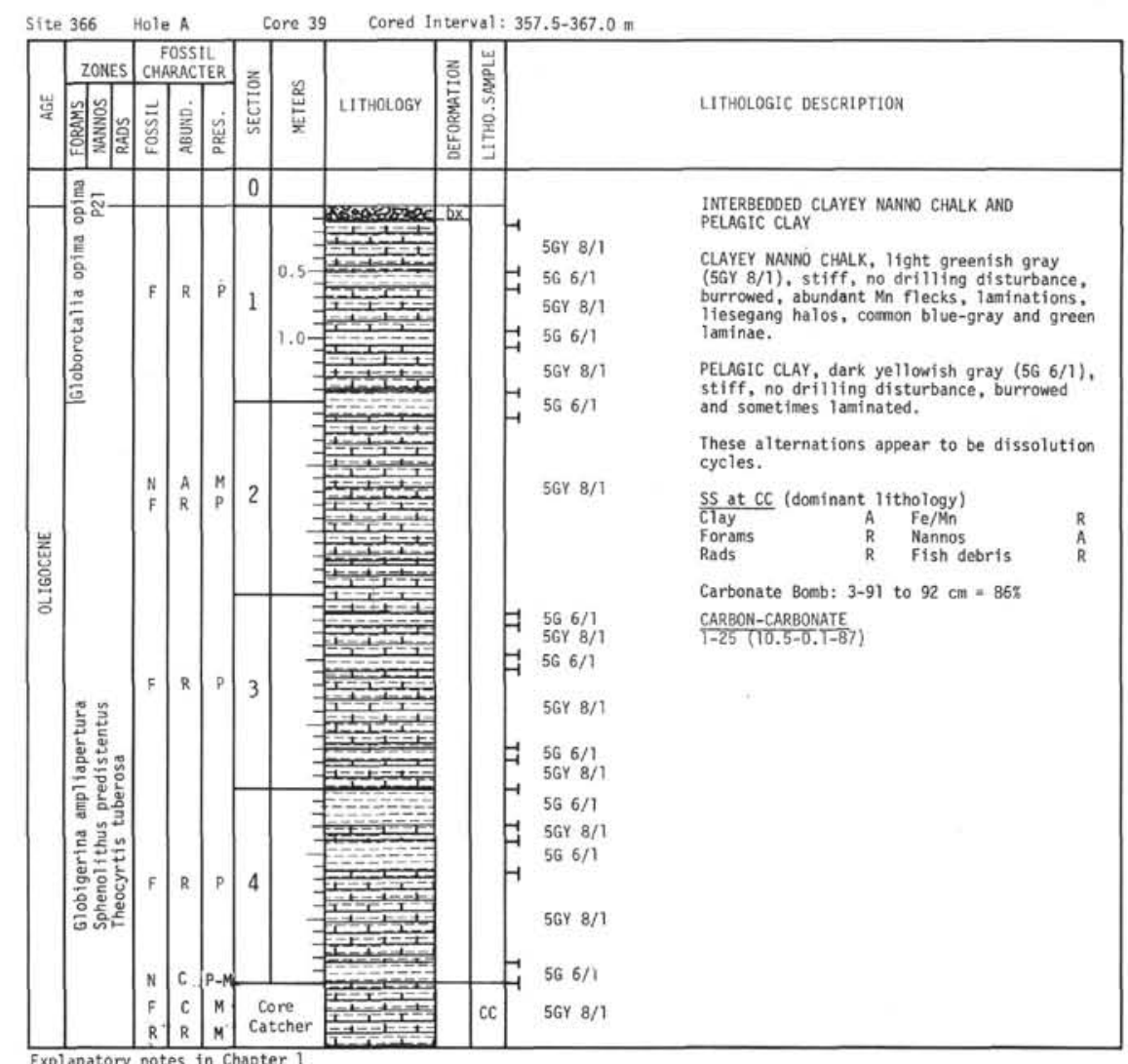




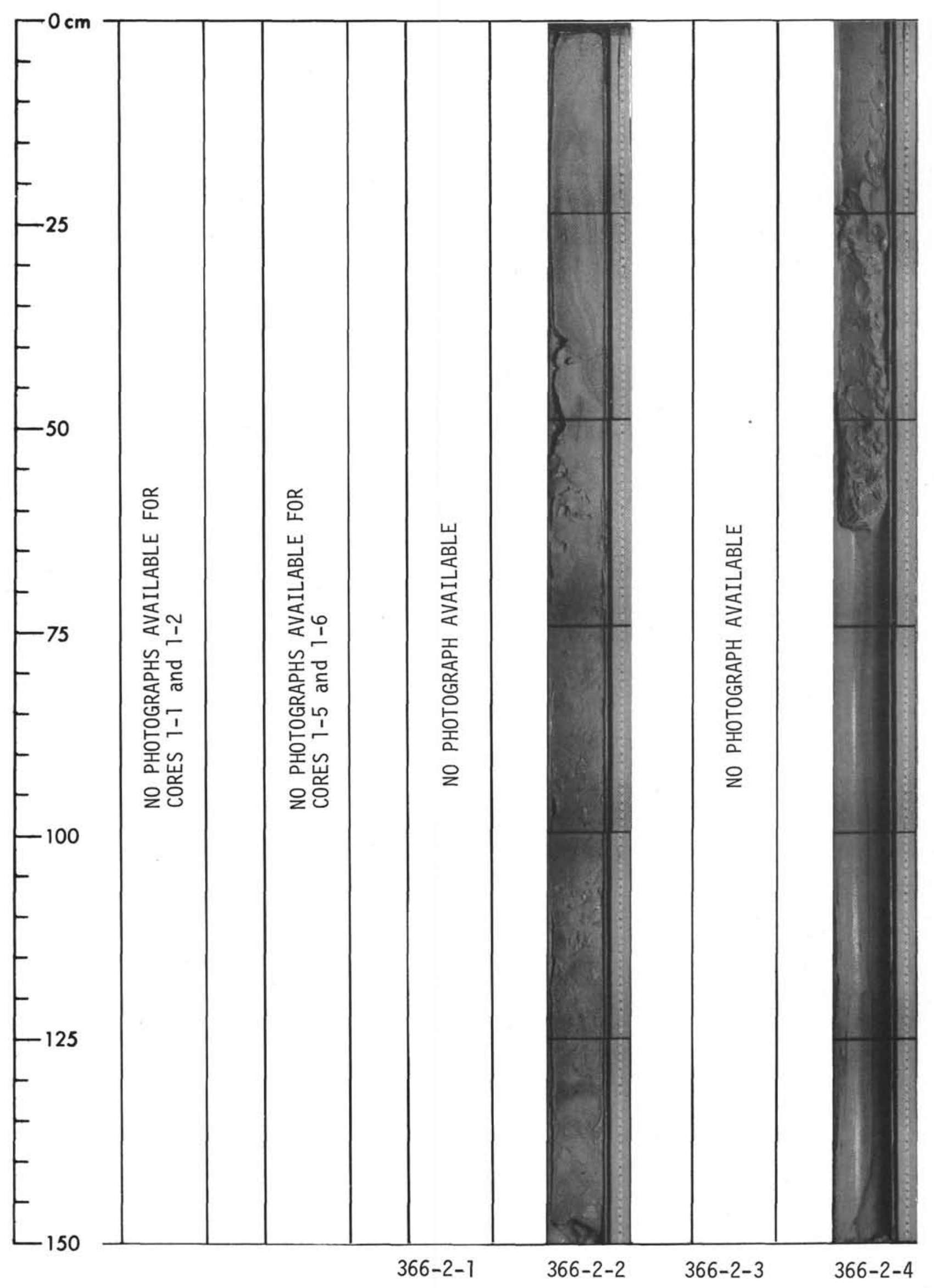


SITE 366: SIERRA LEONE RISE

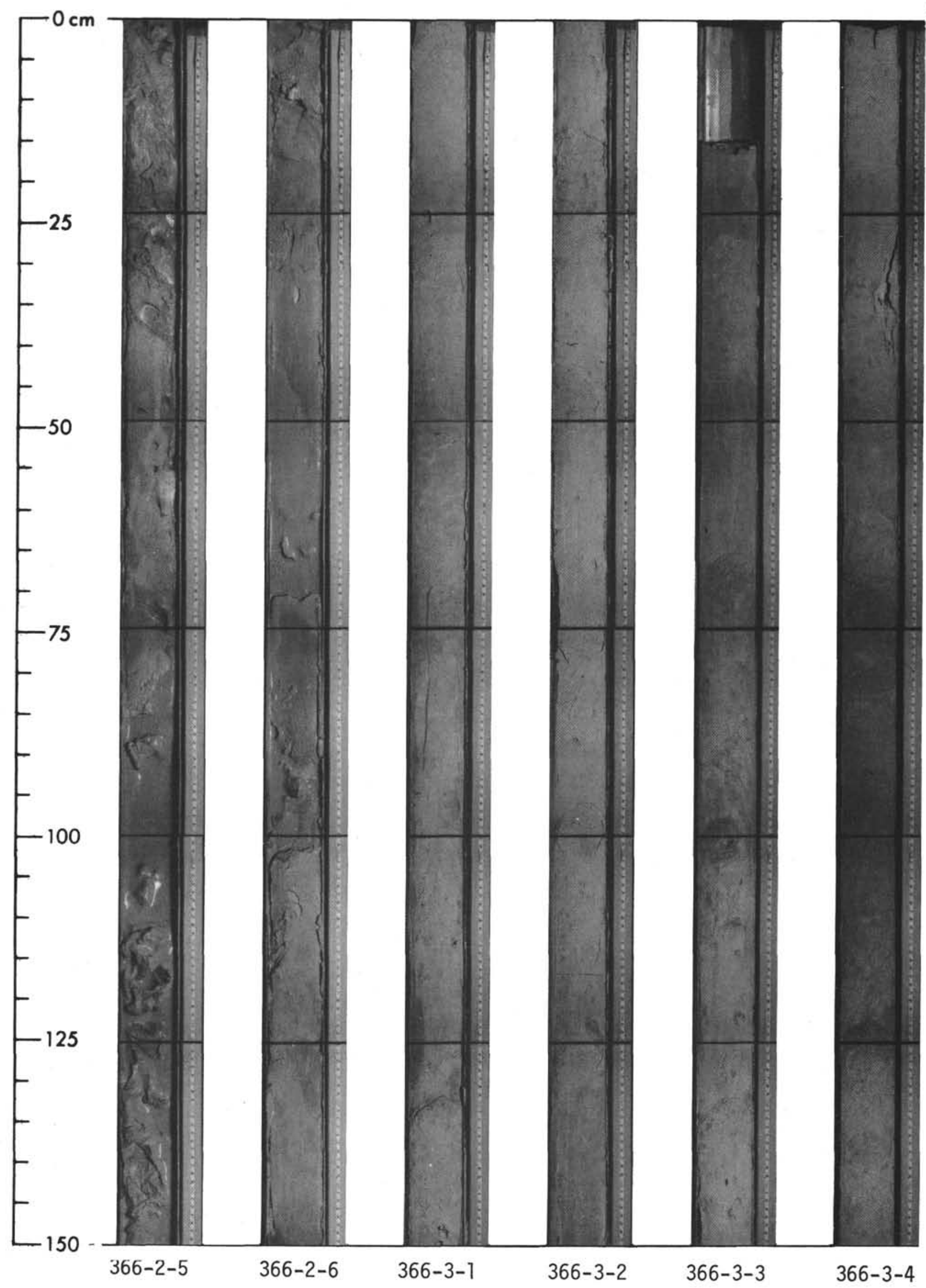




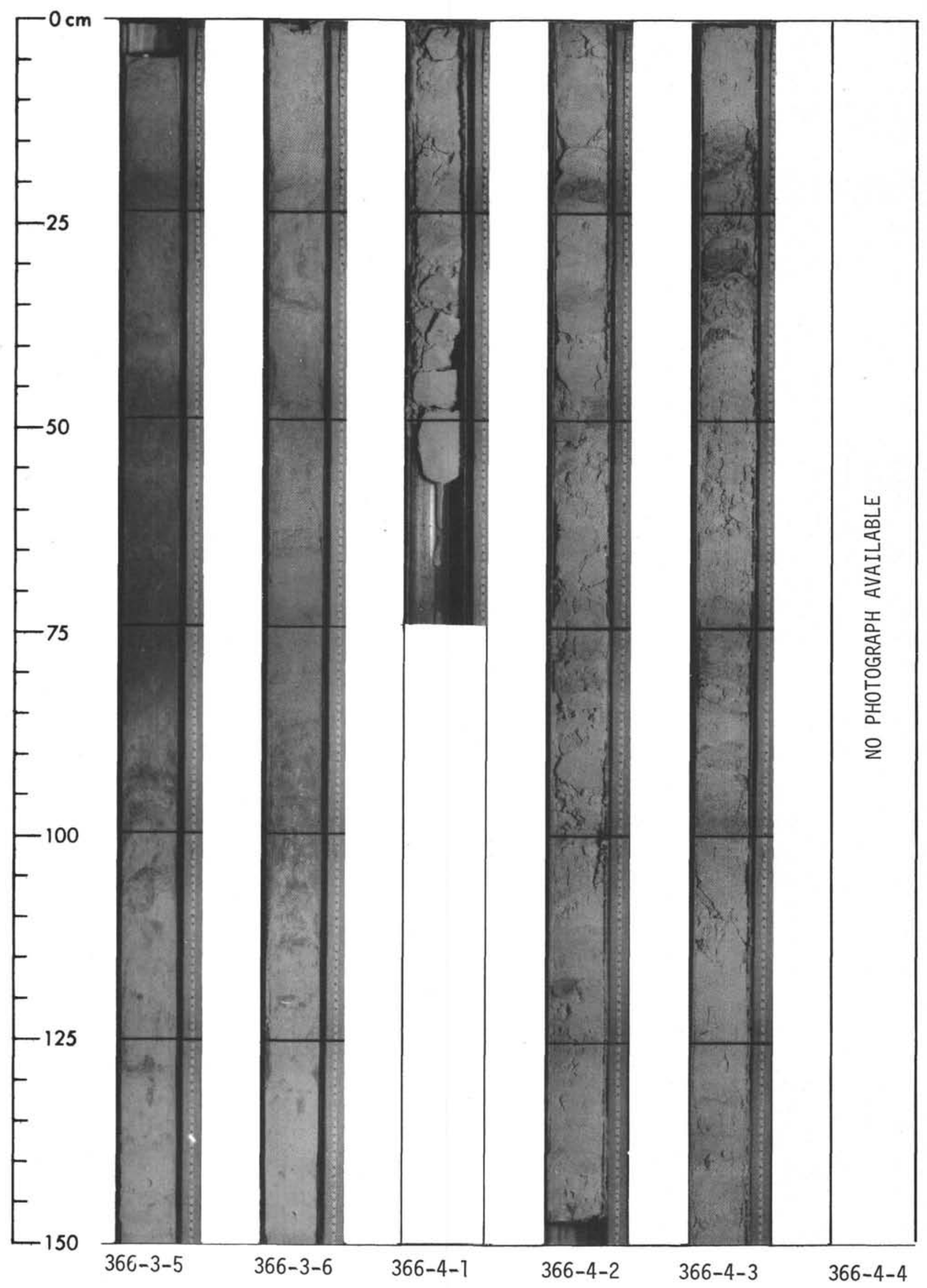




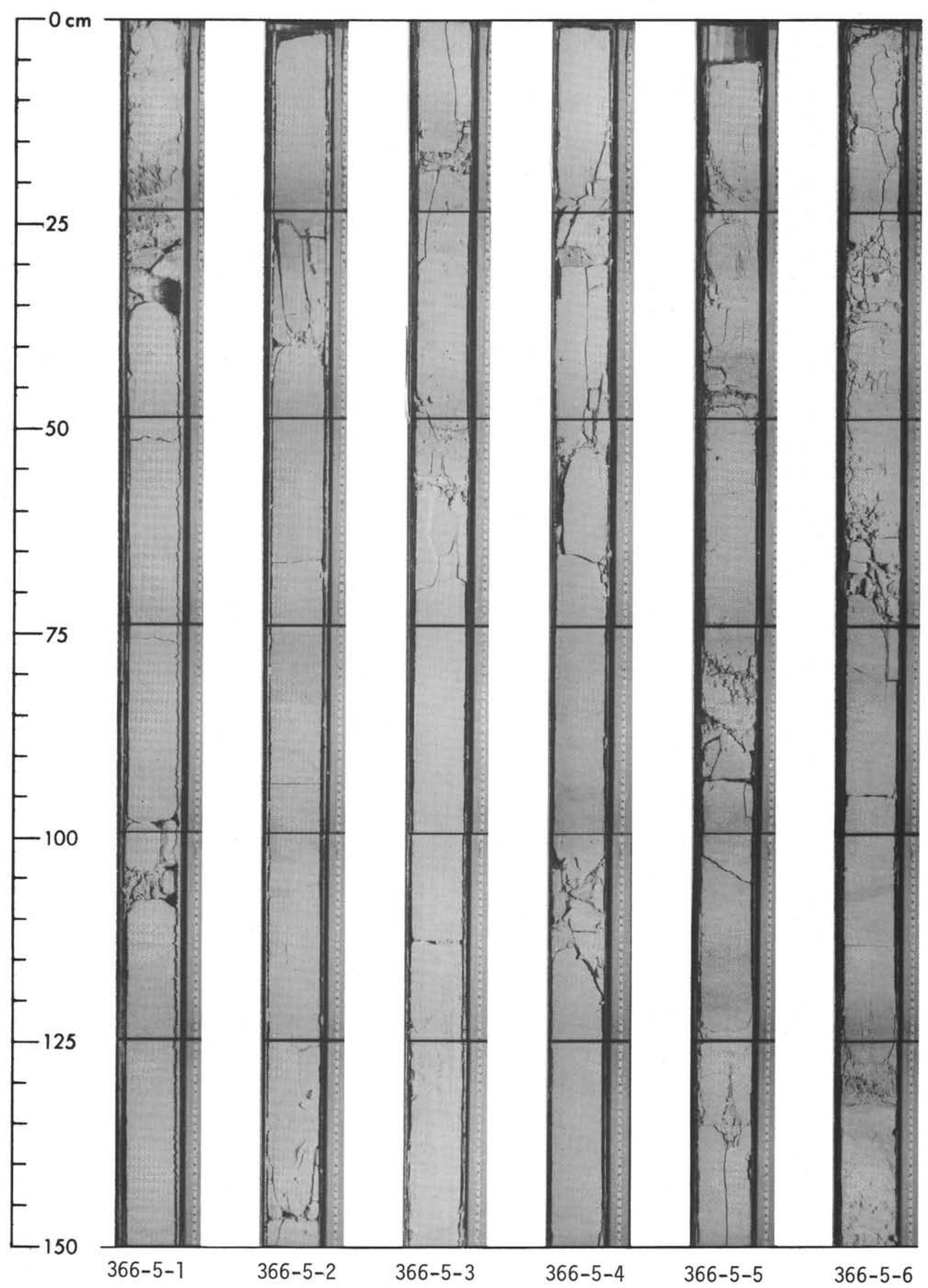




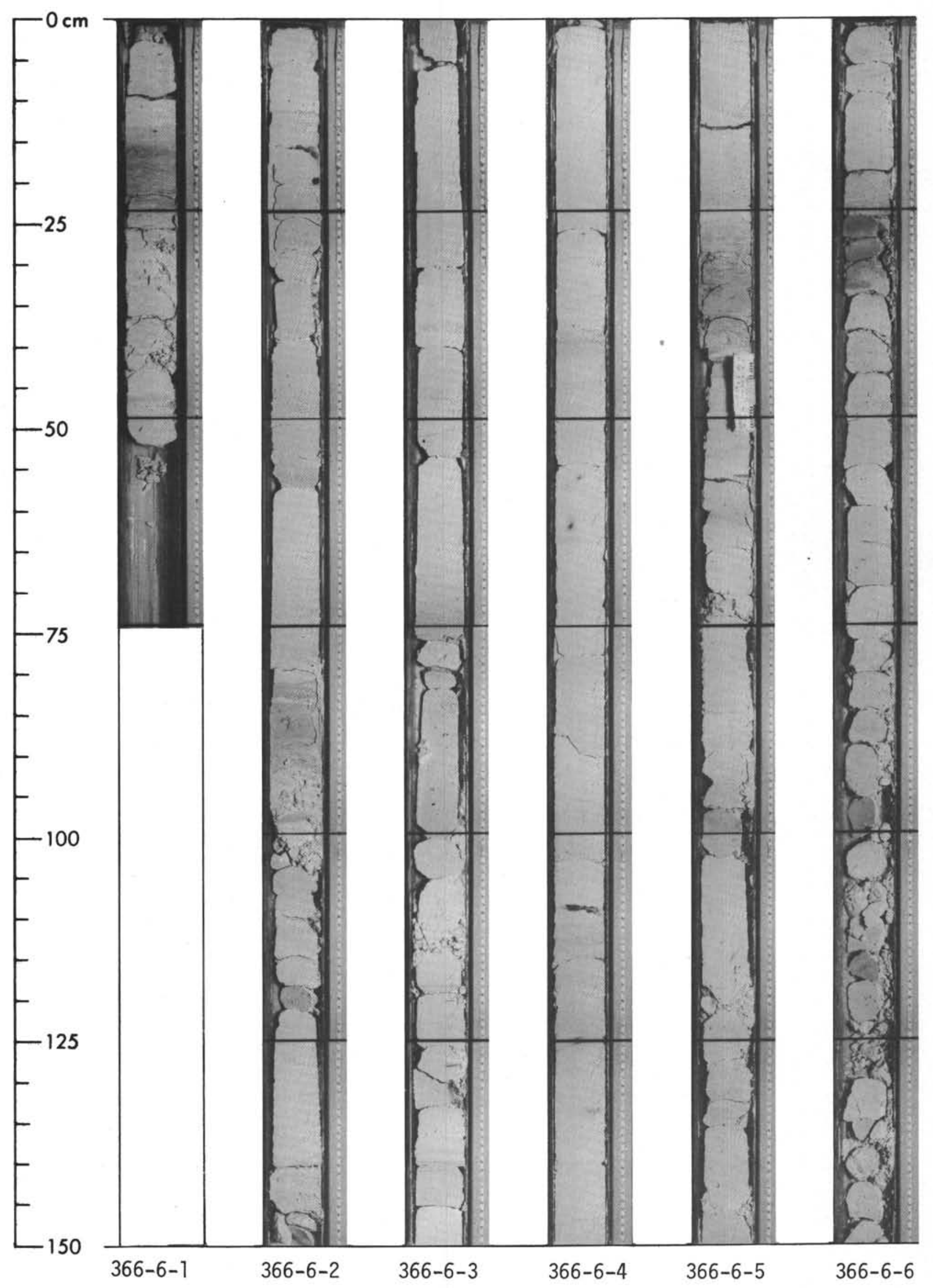




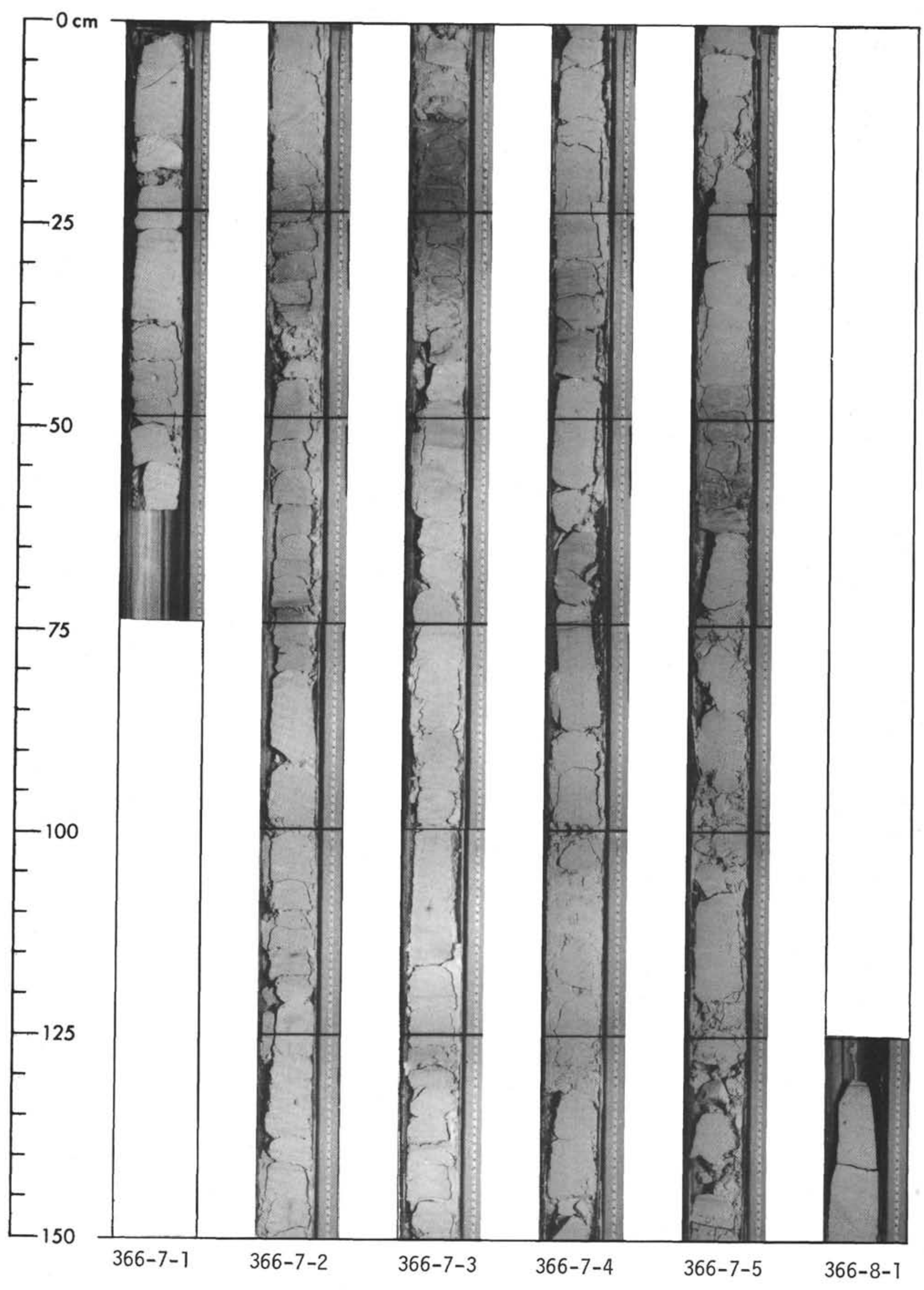




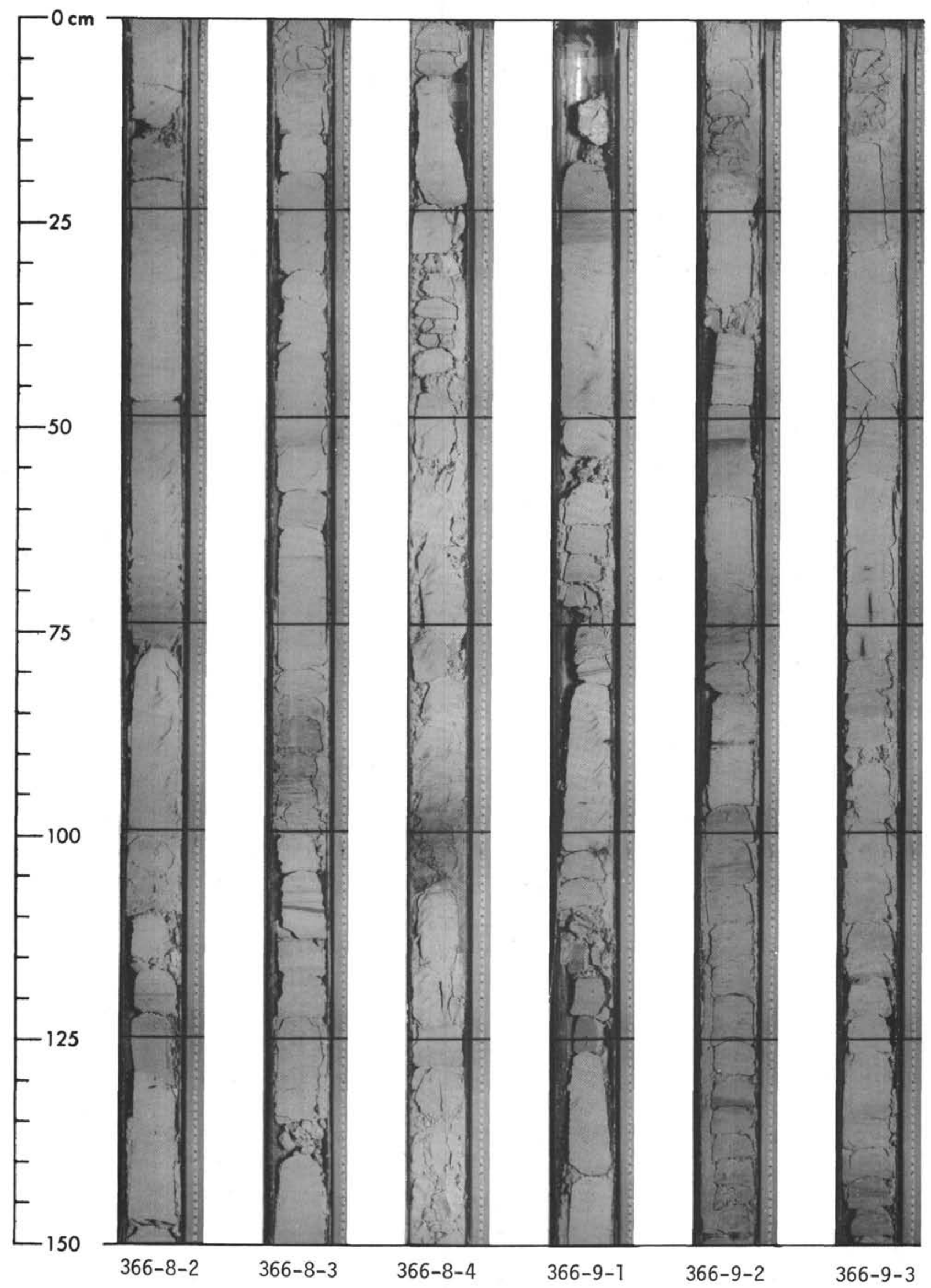




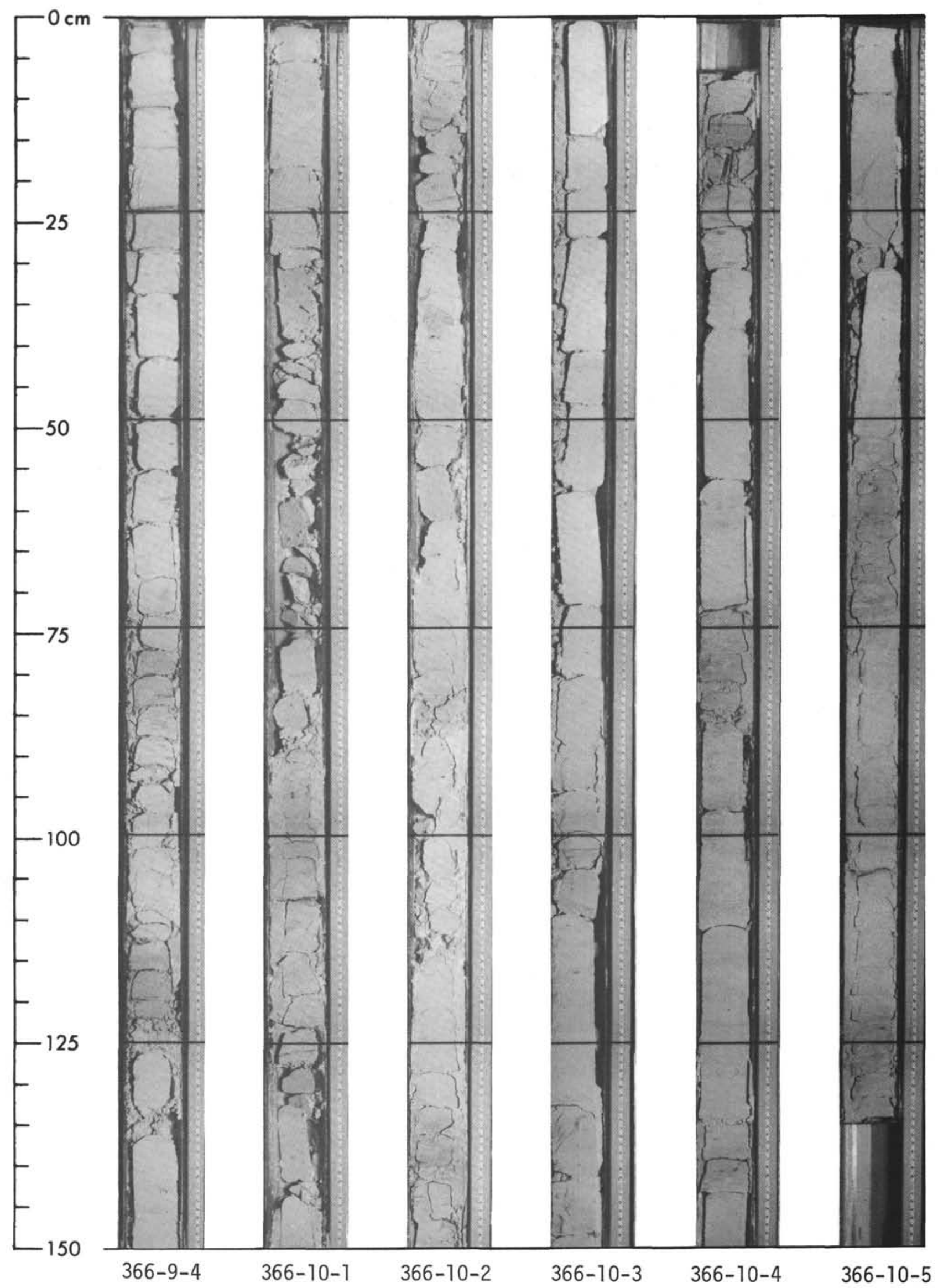




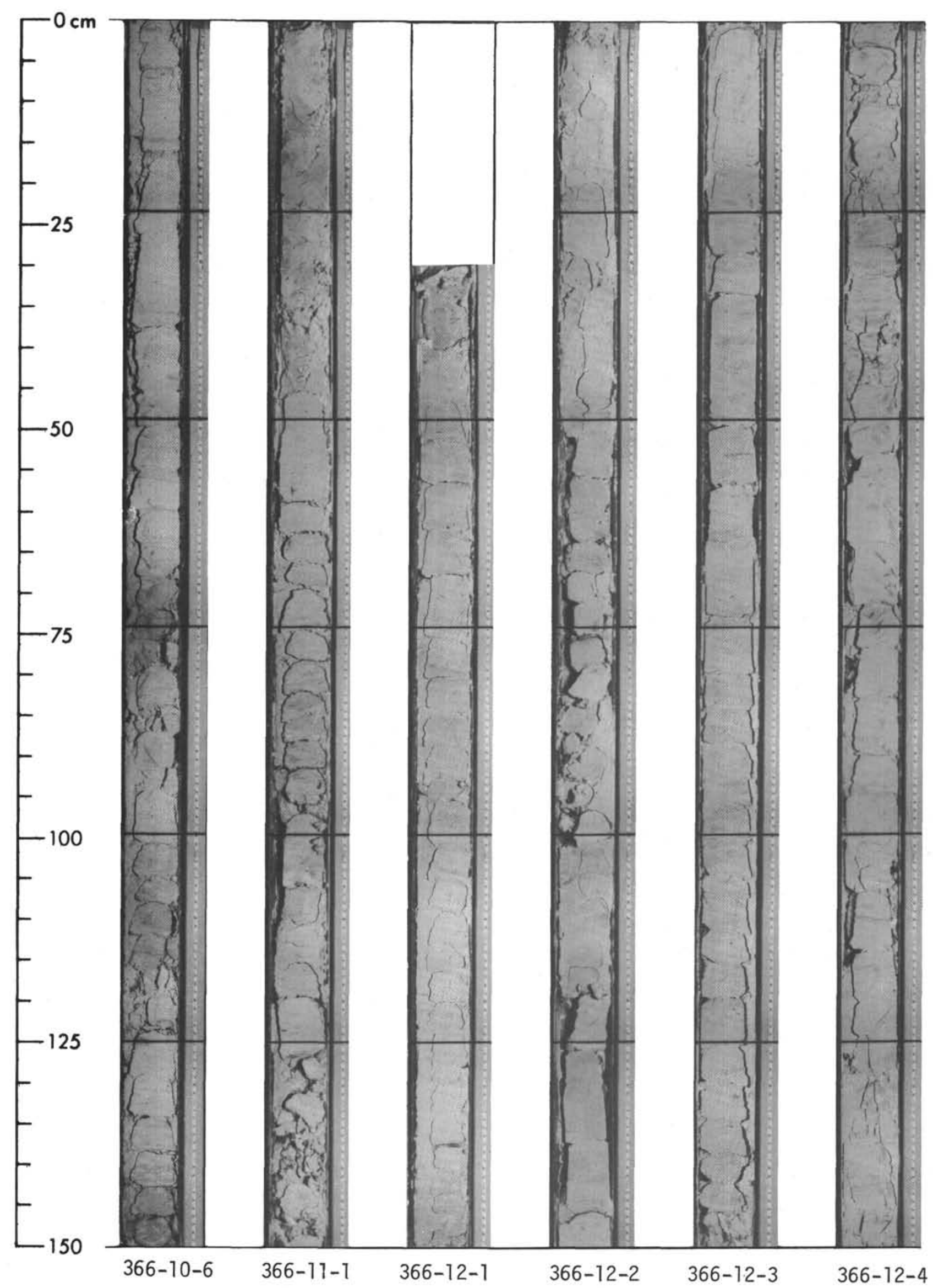




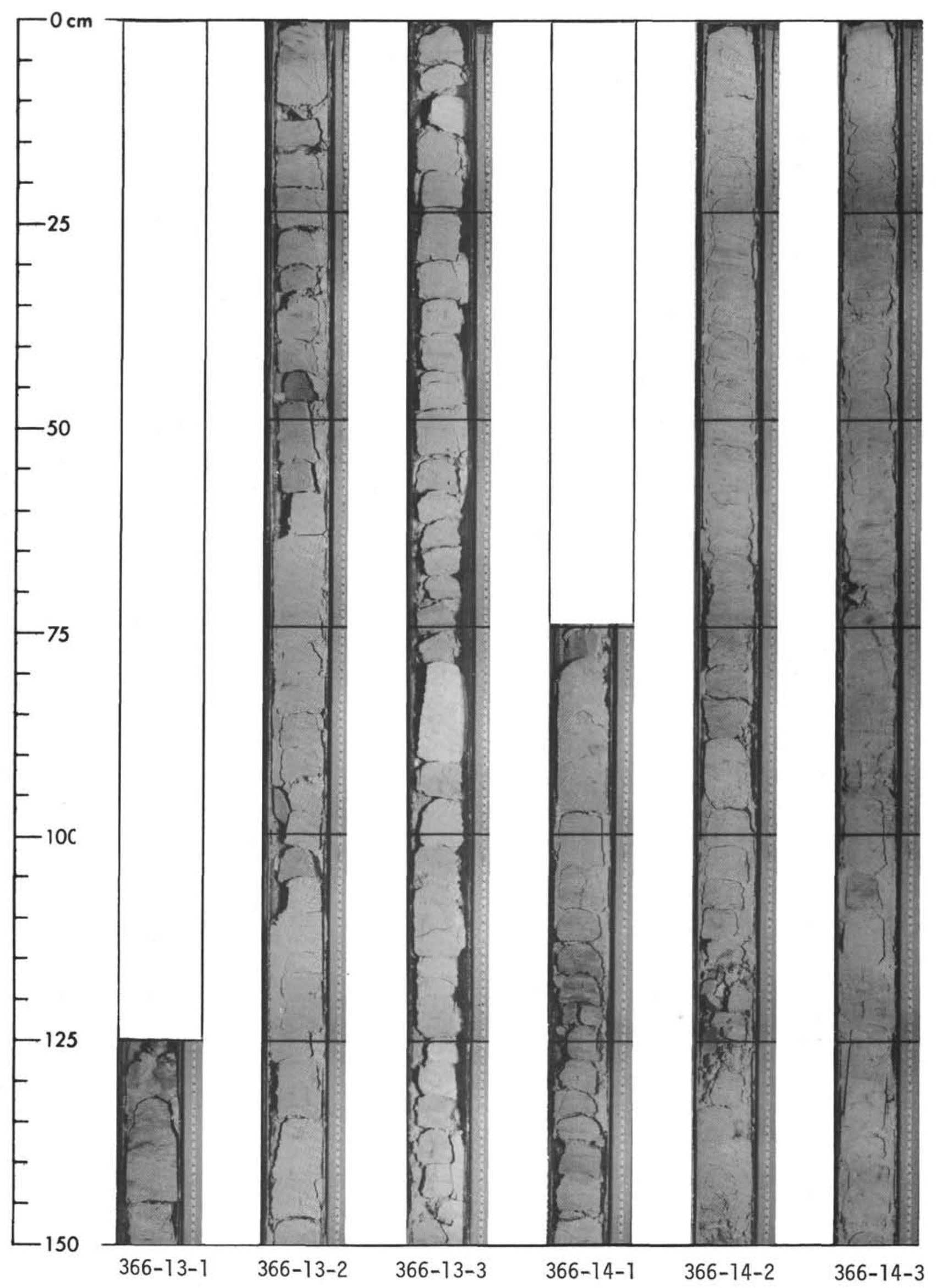




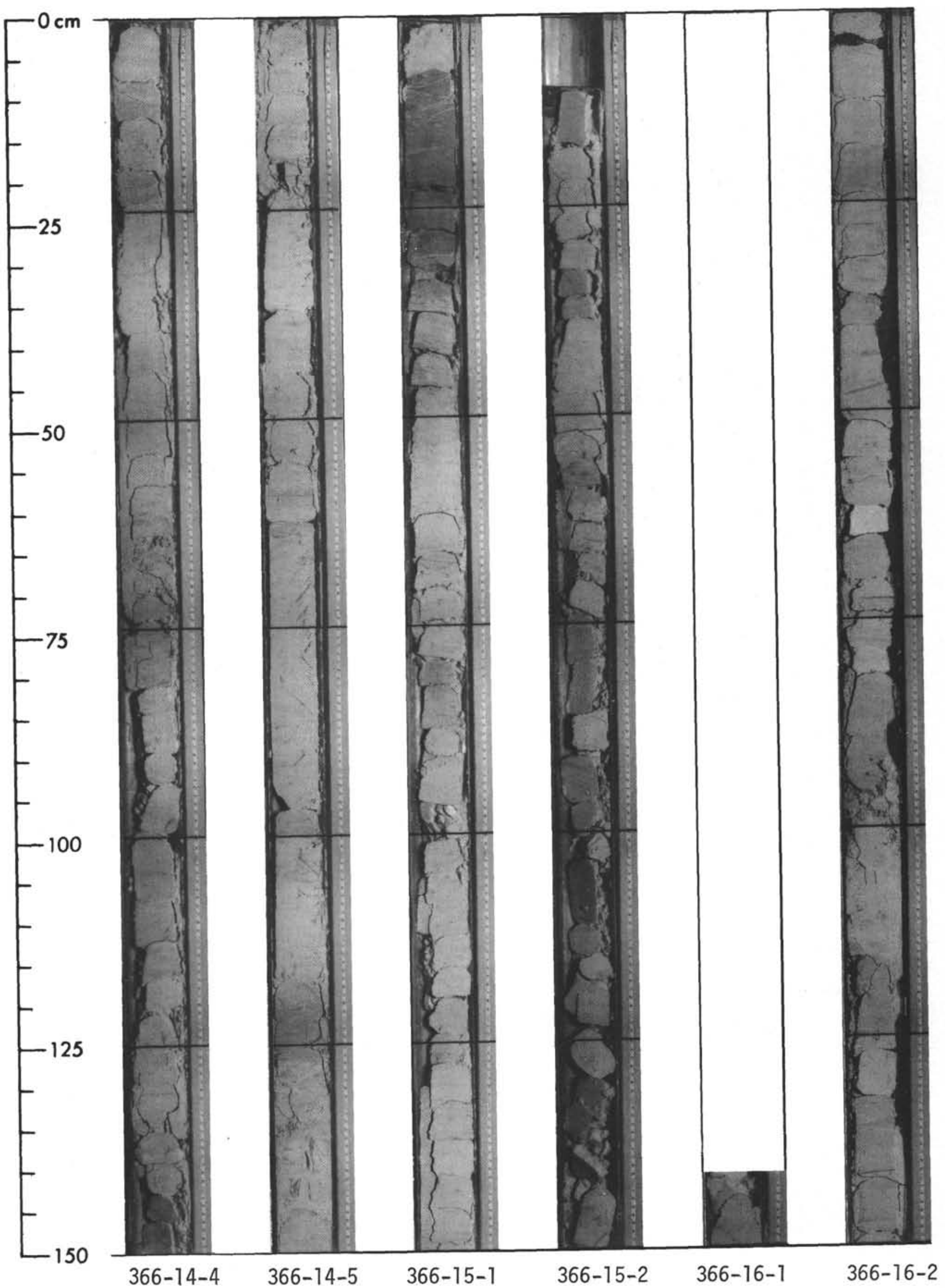


SITE 366: SIERRA LEONE RISE

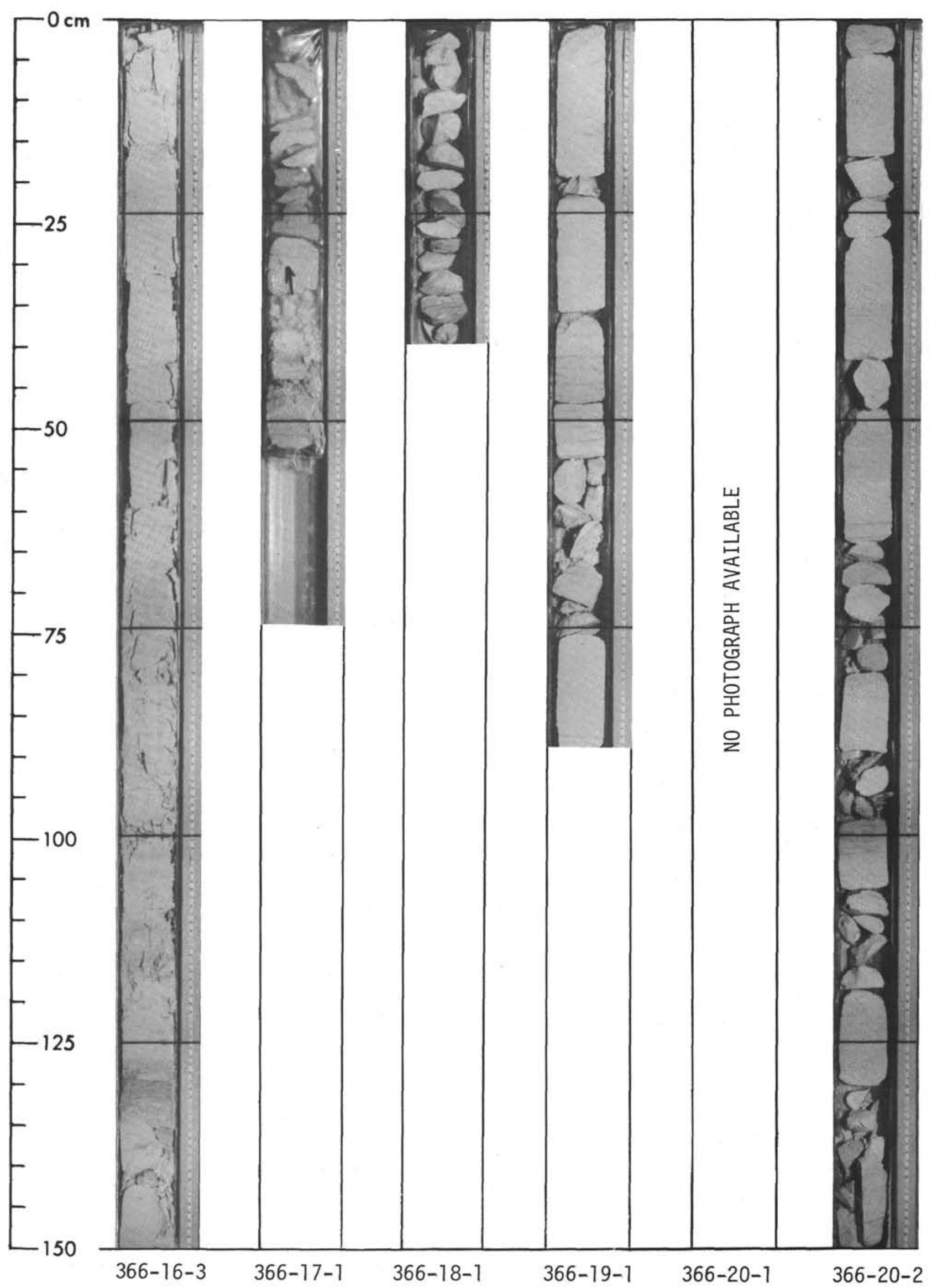




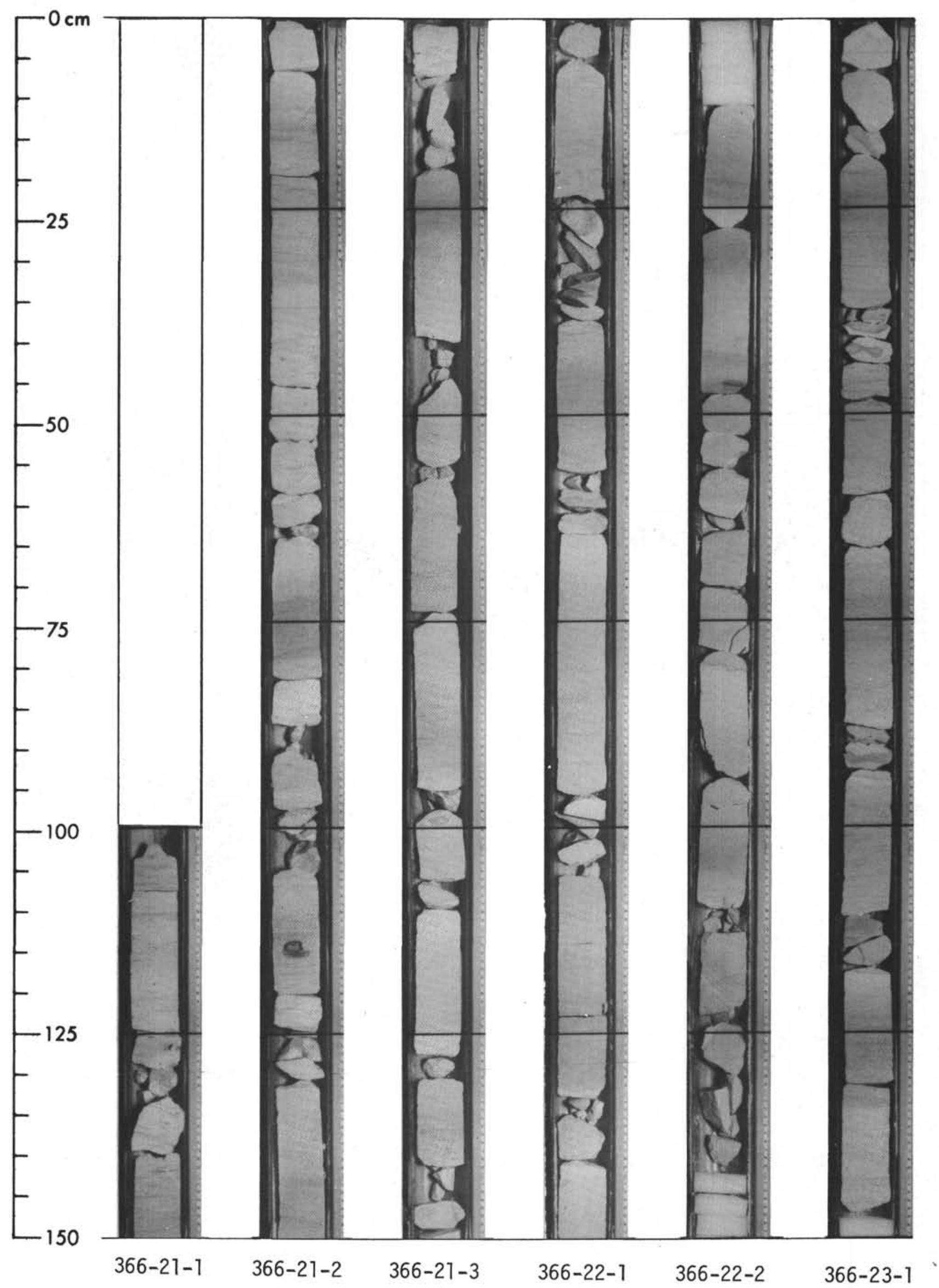




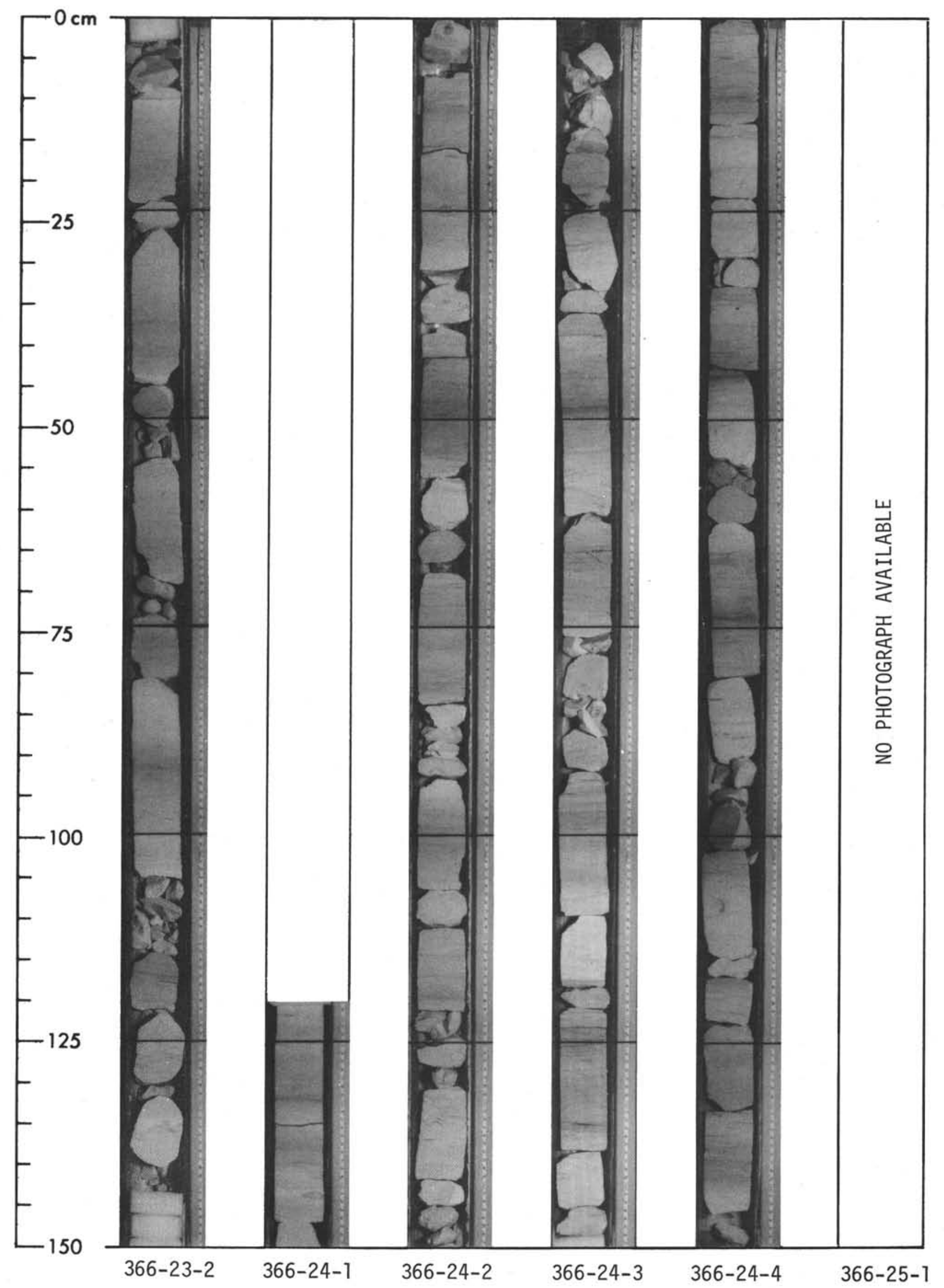




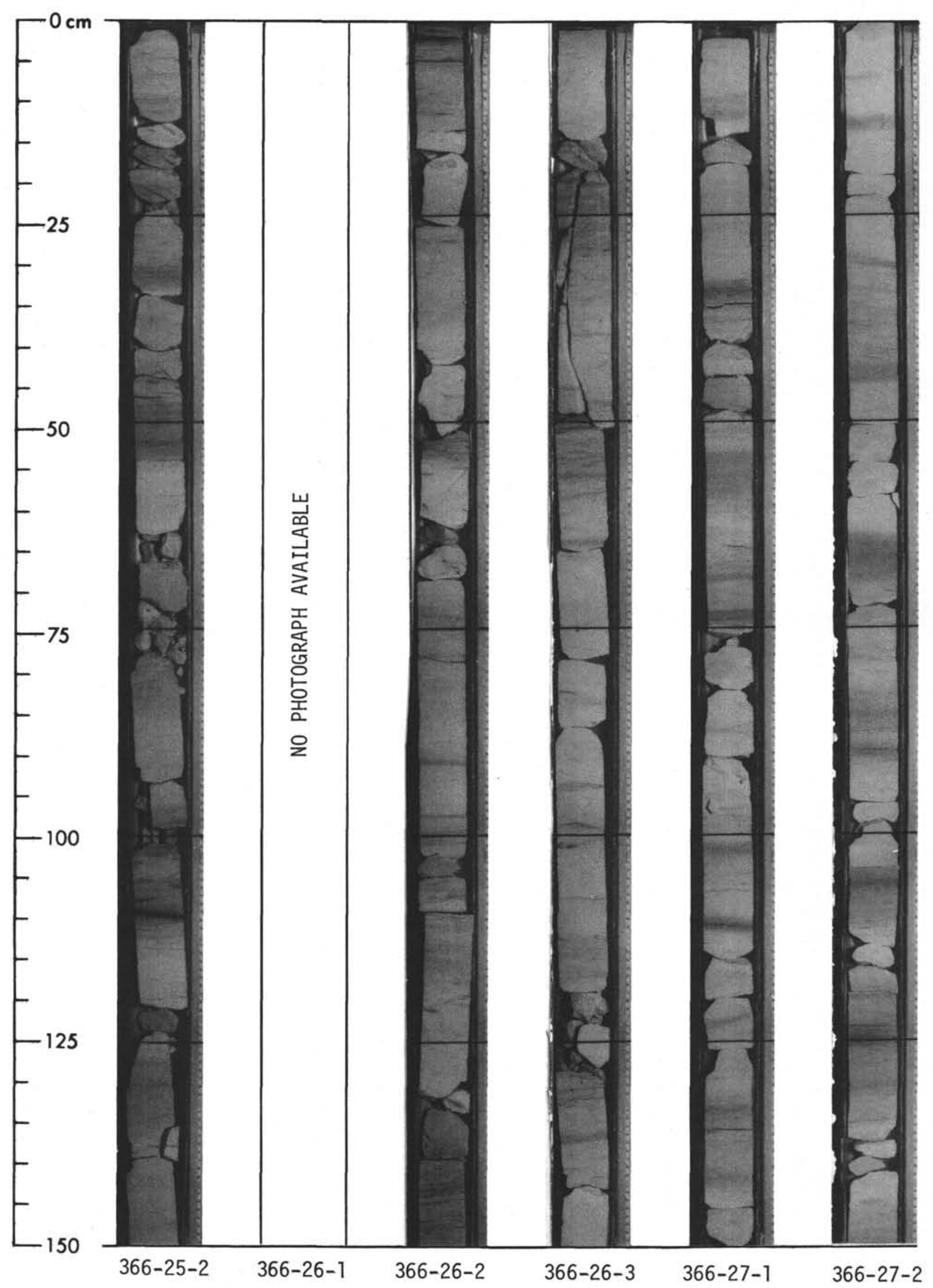




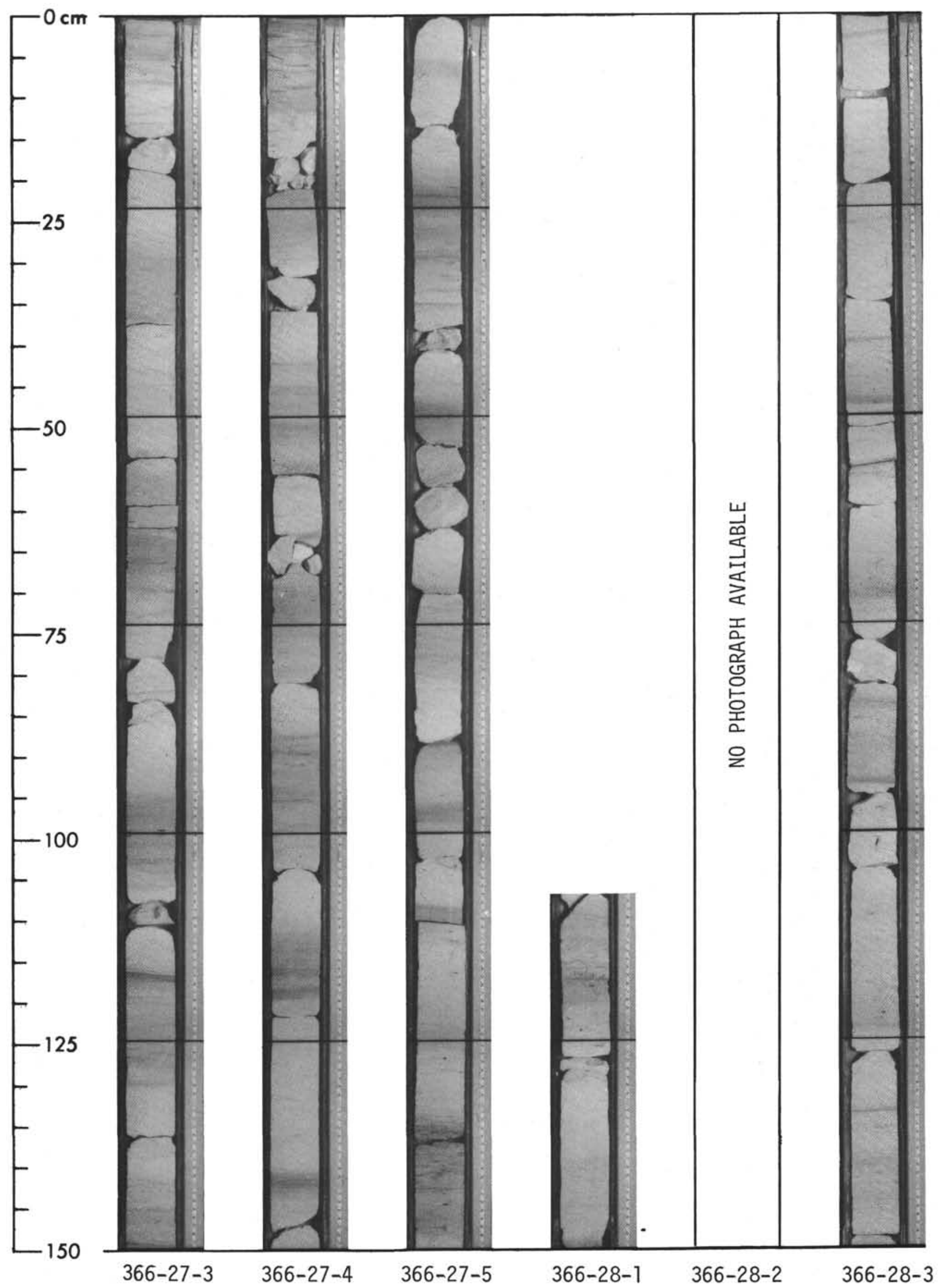




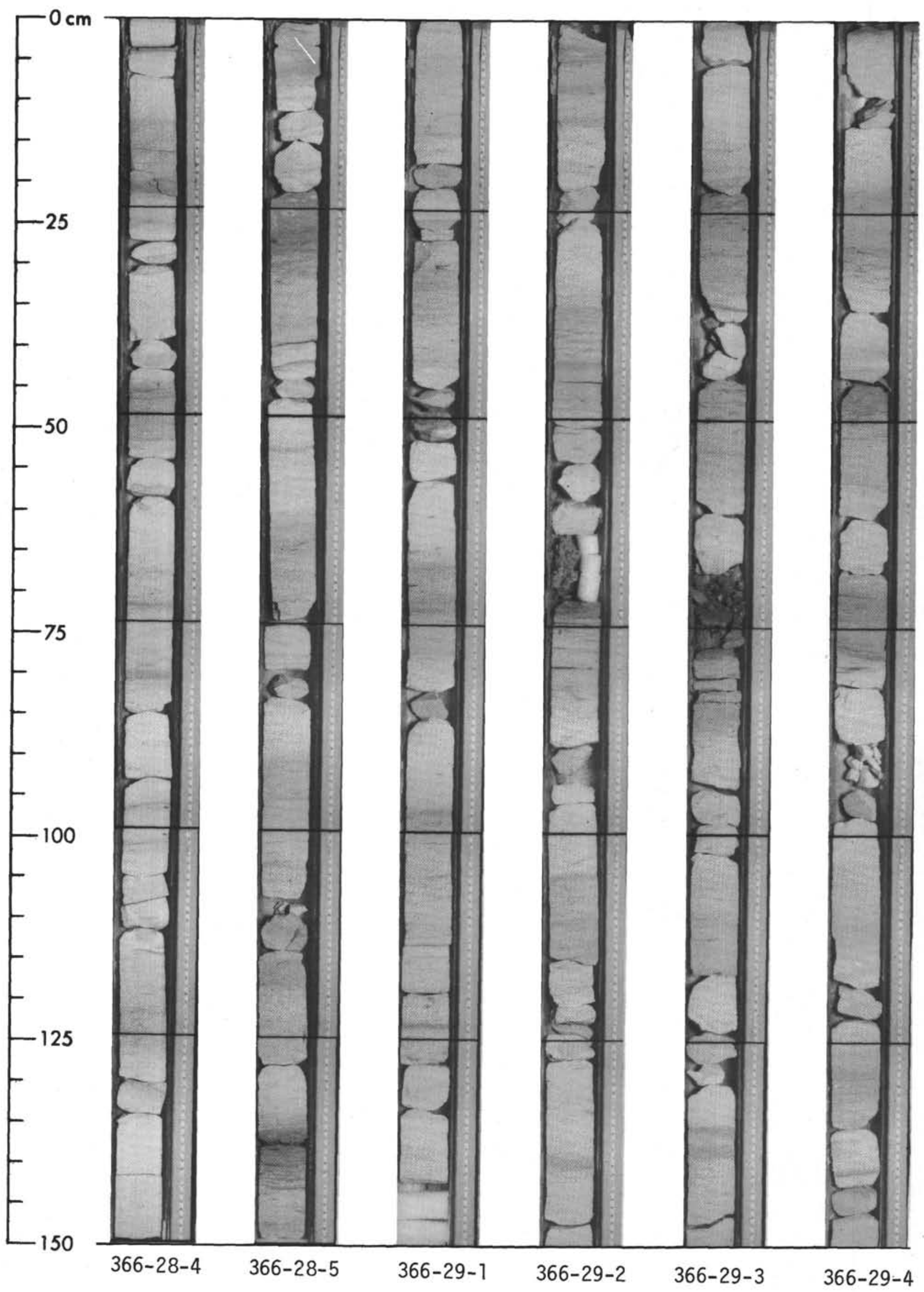




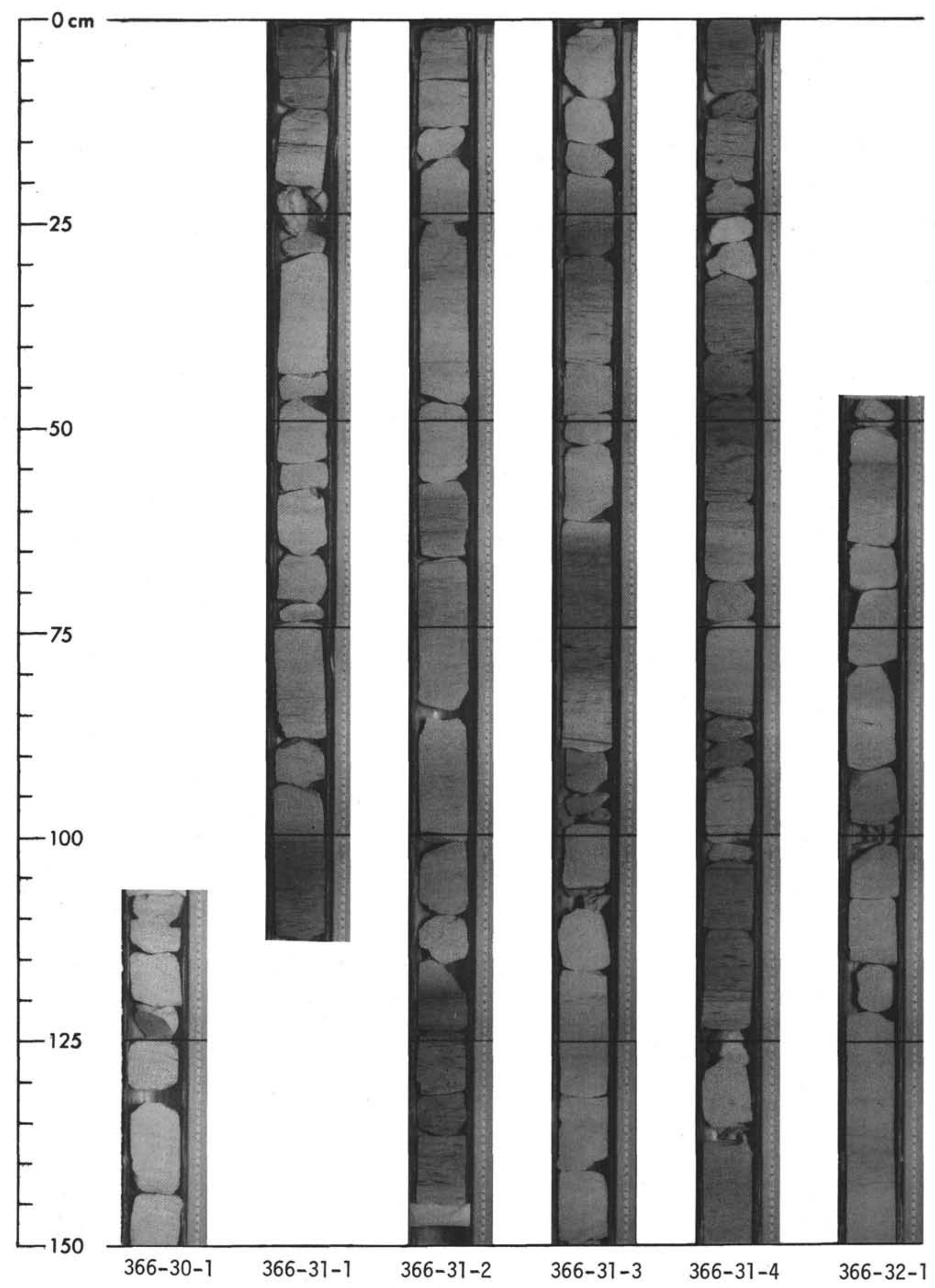




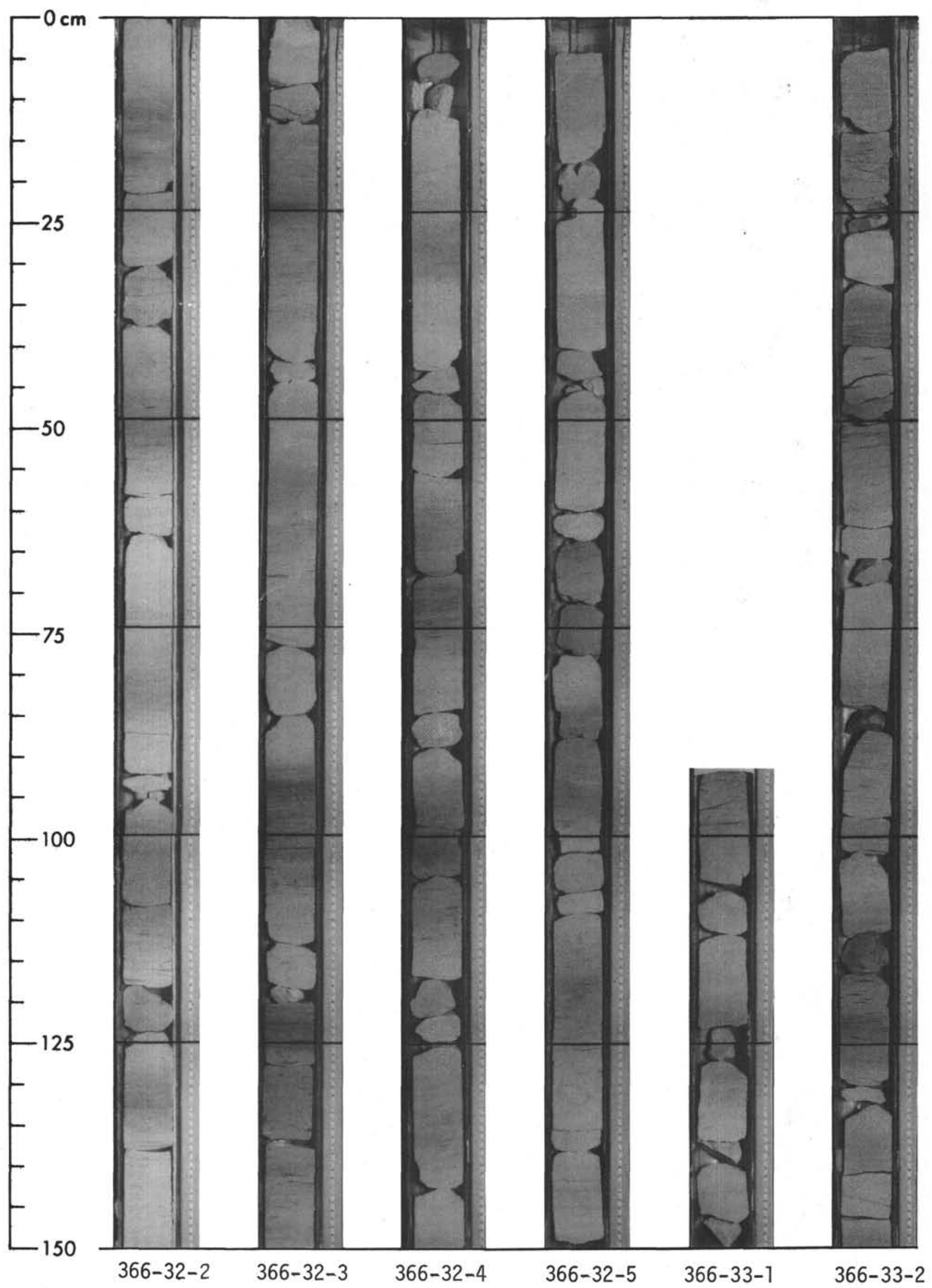


SITE 366: SIERRA LEONE RISE

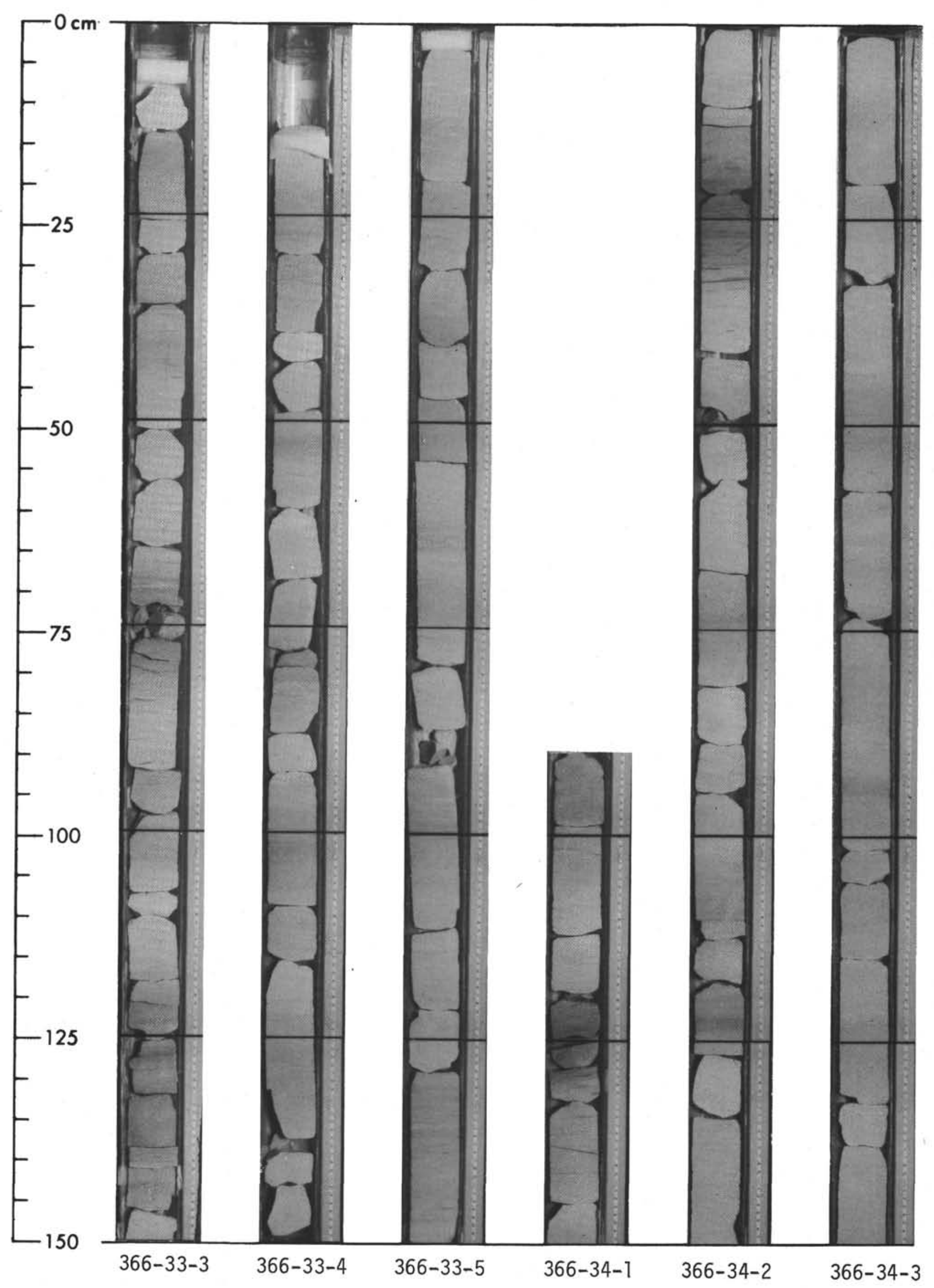




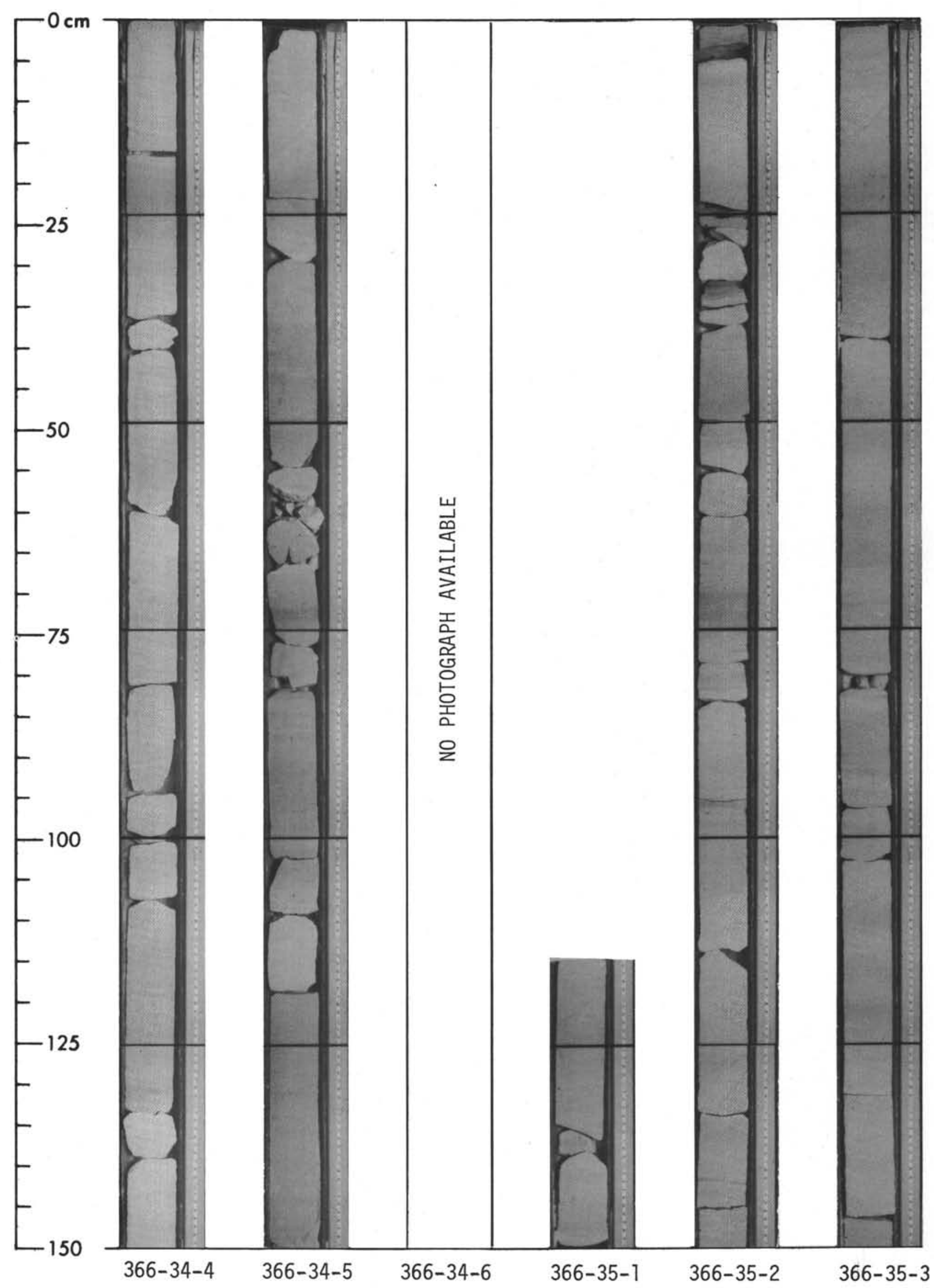




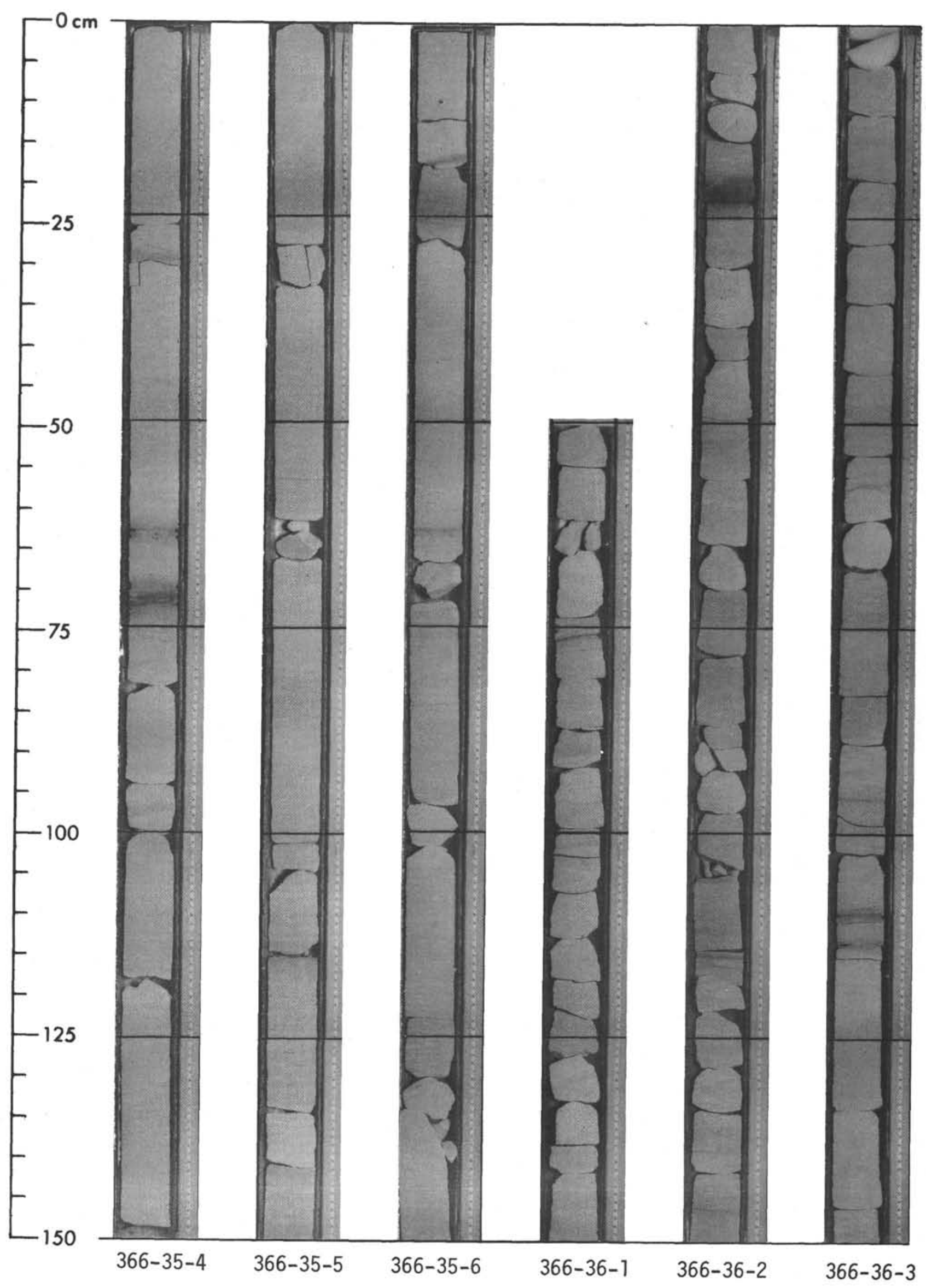




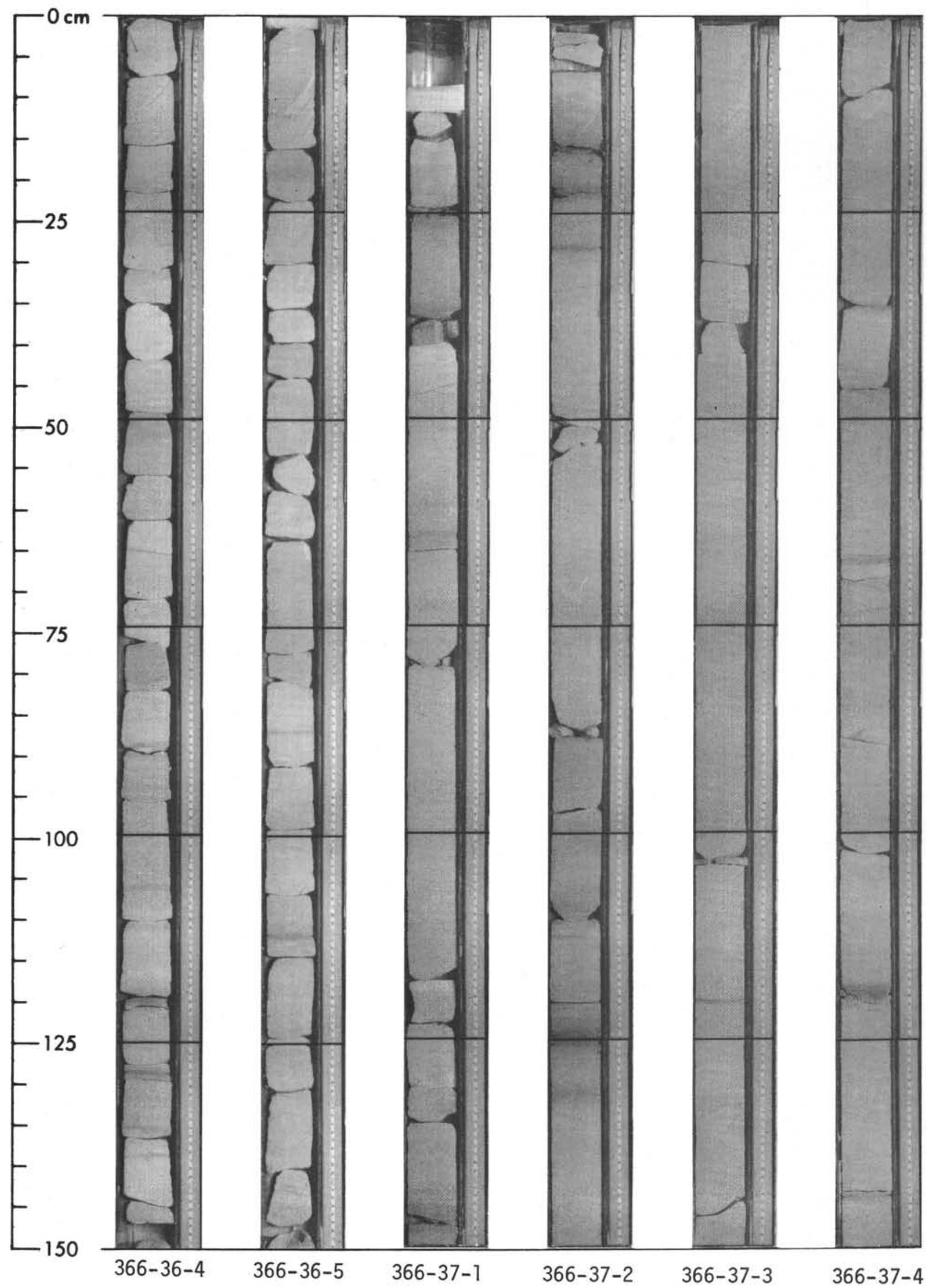




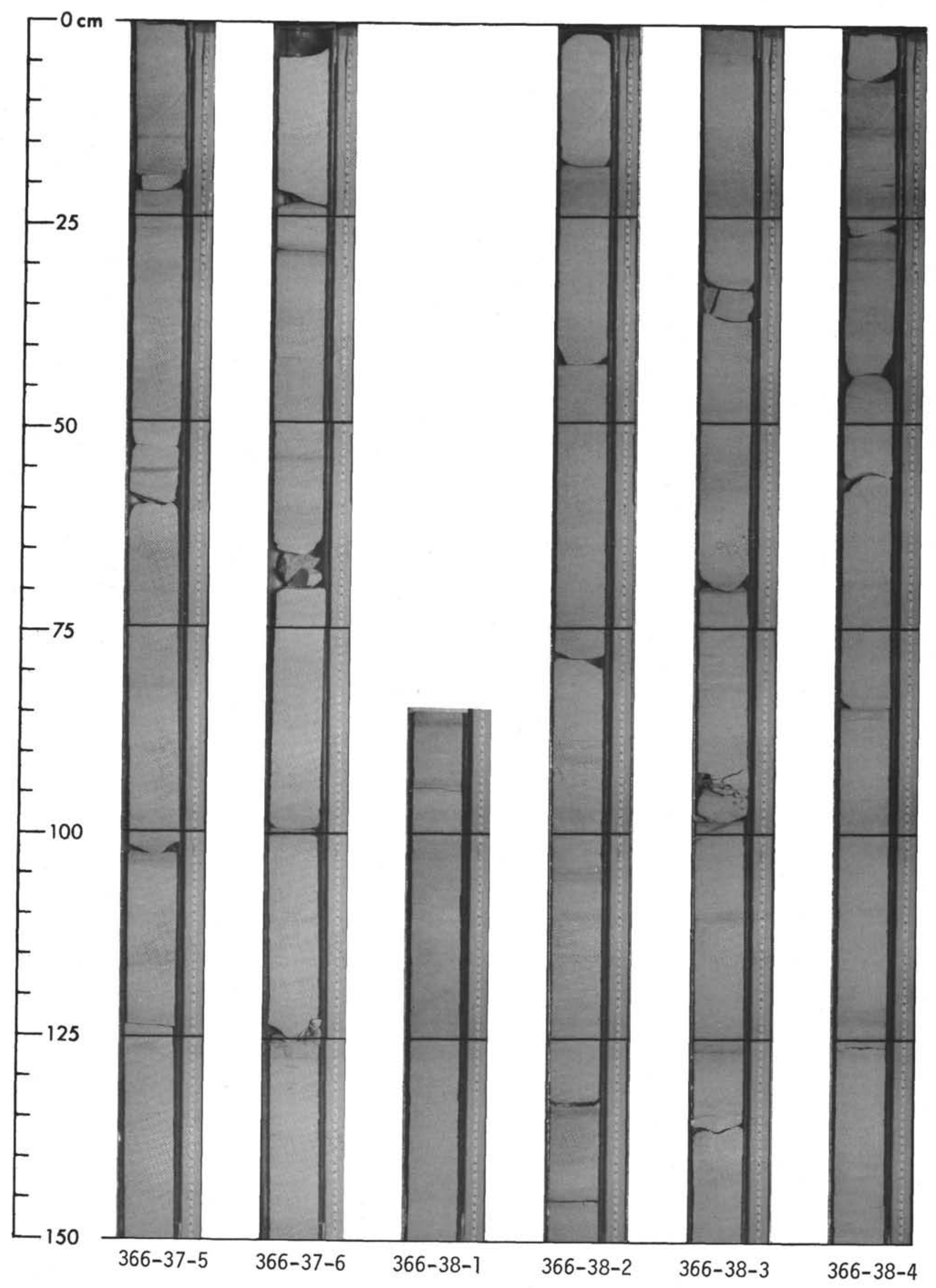




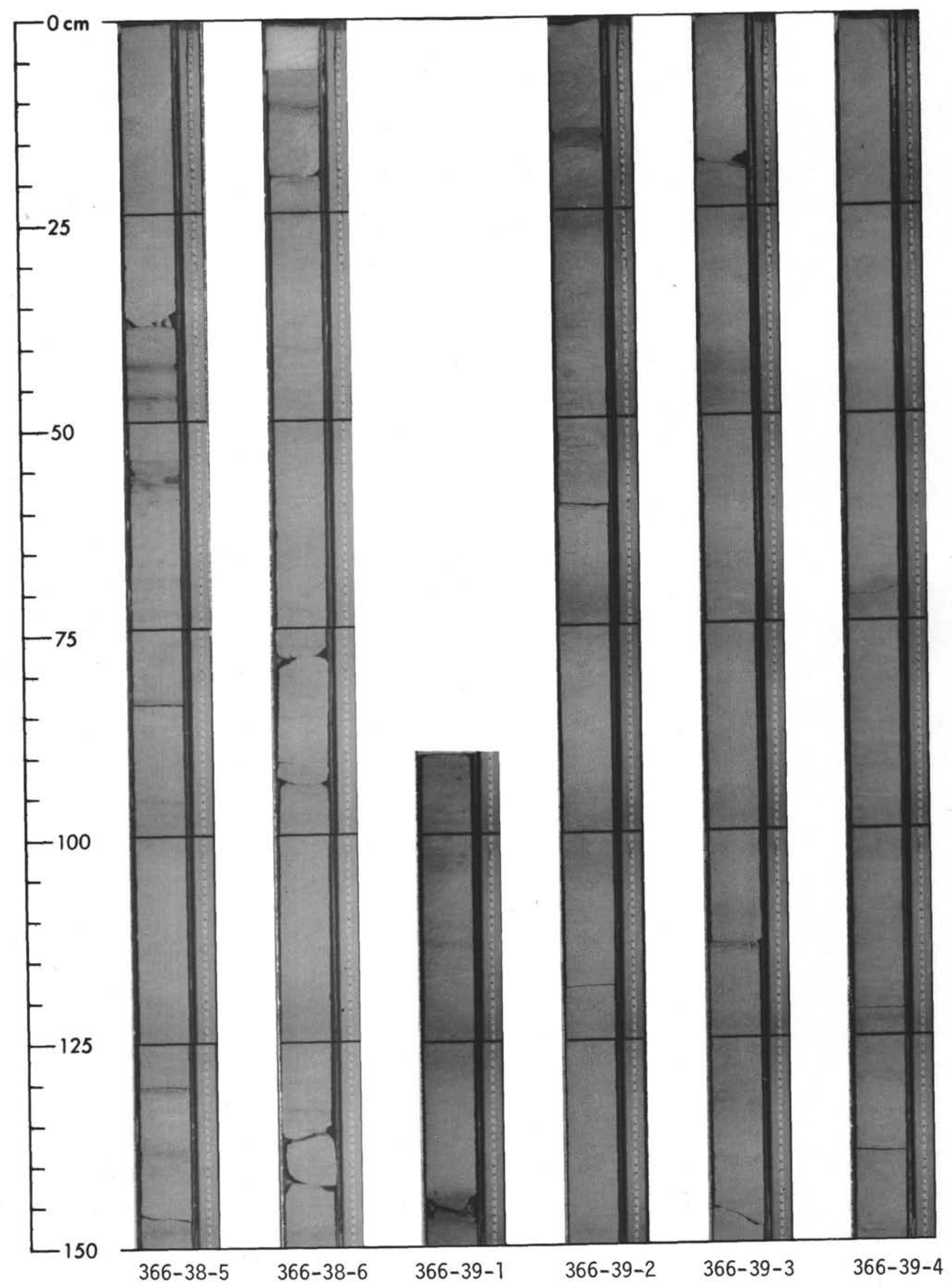




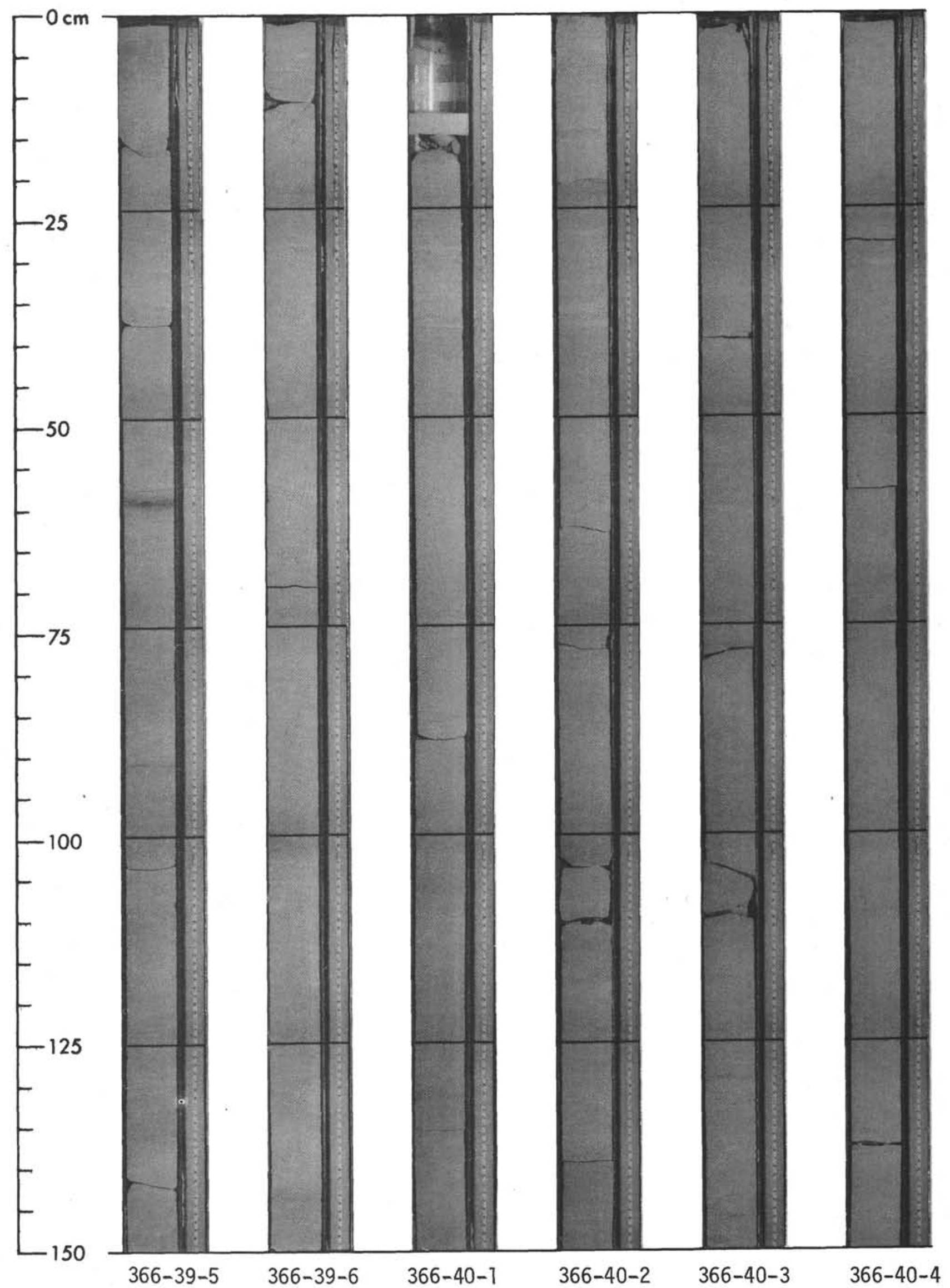




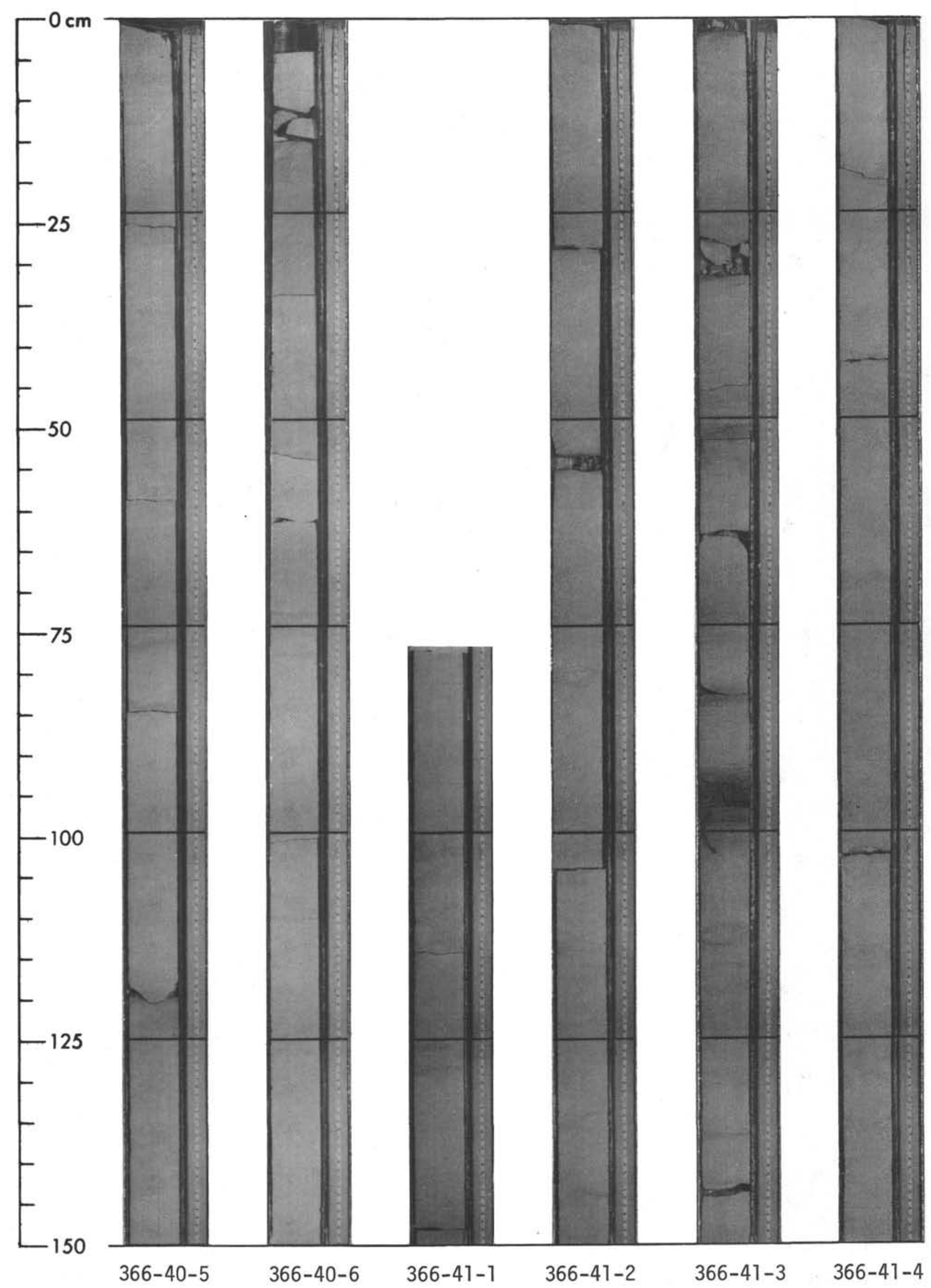




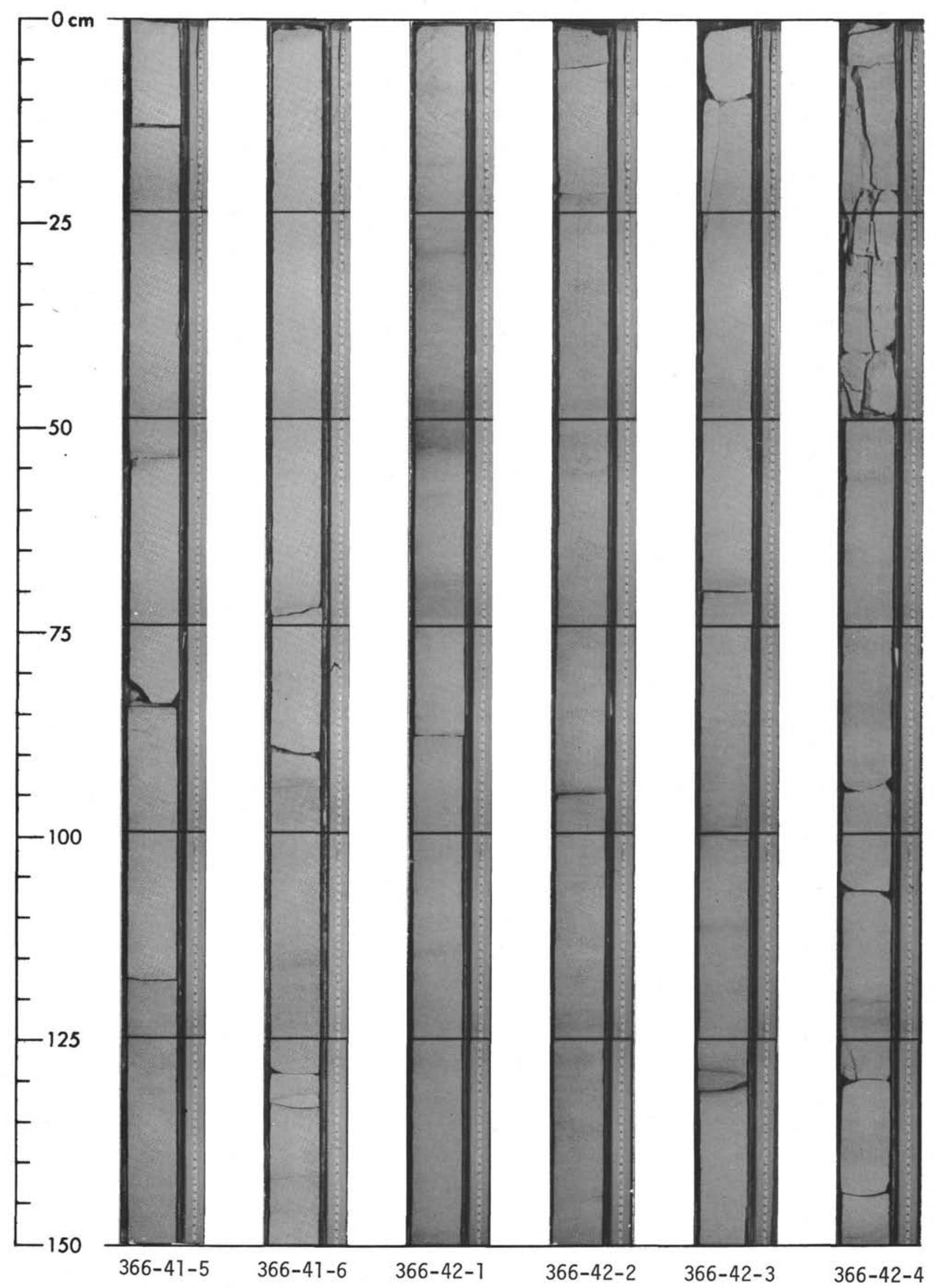




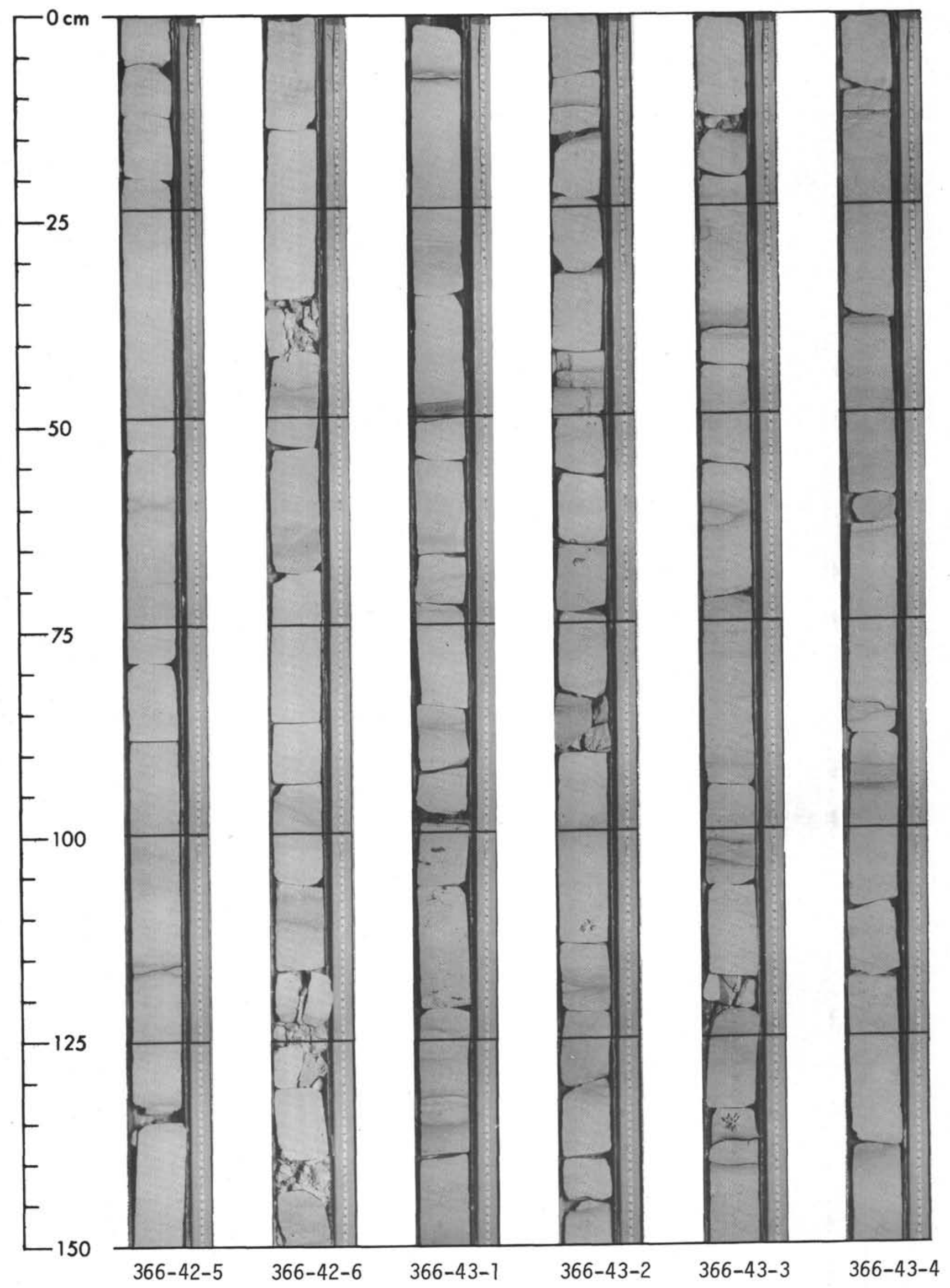




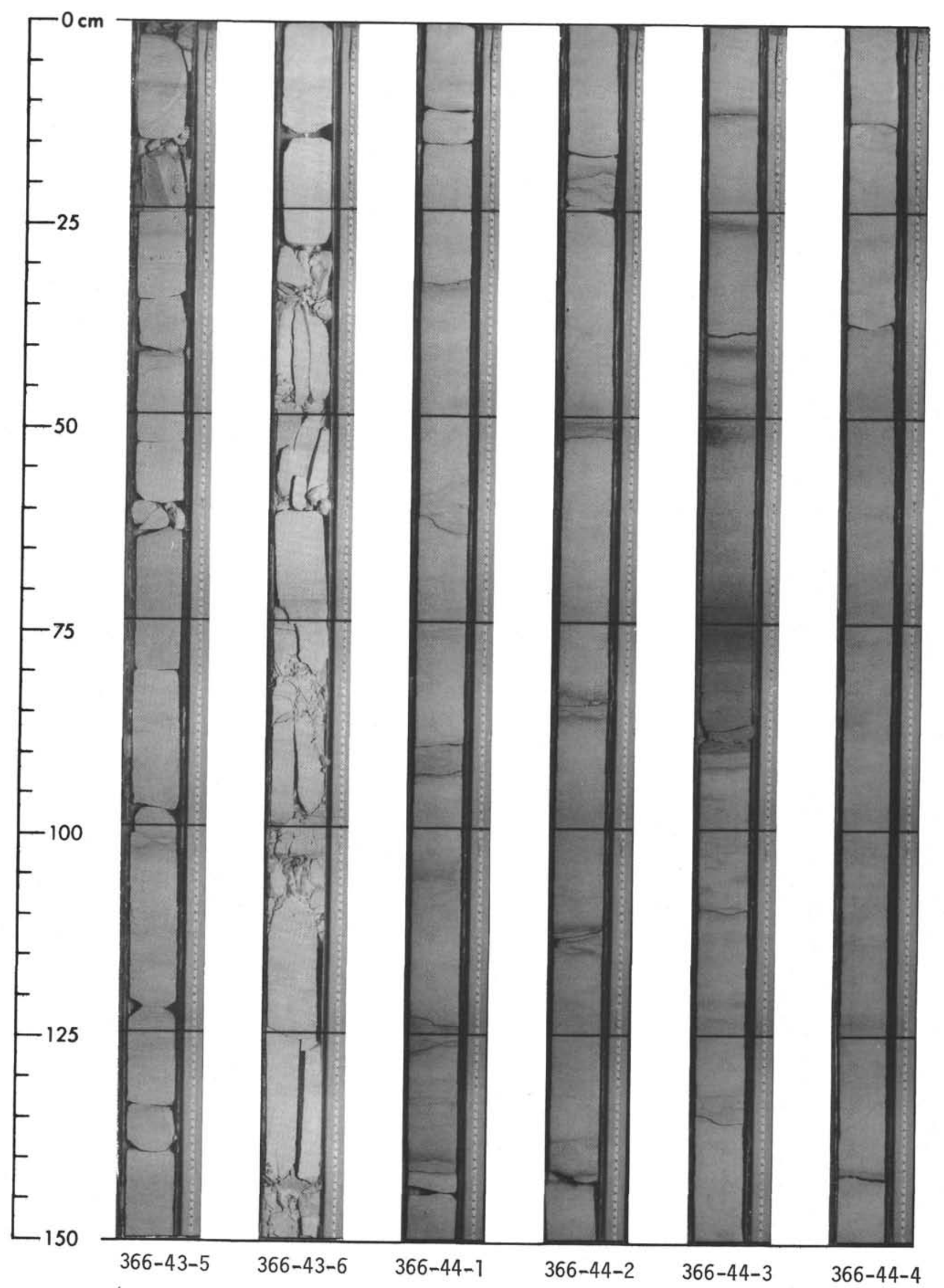




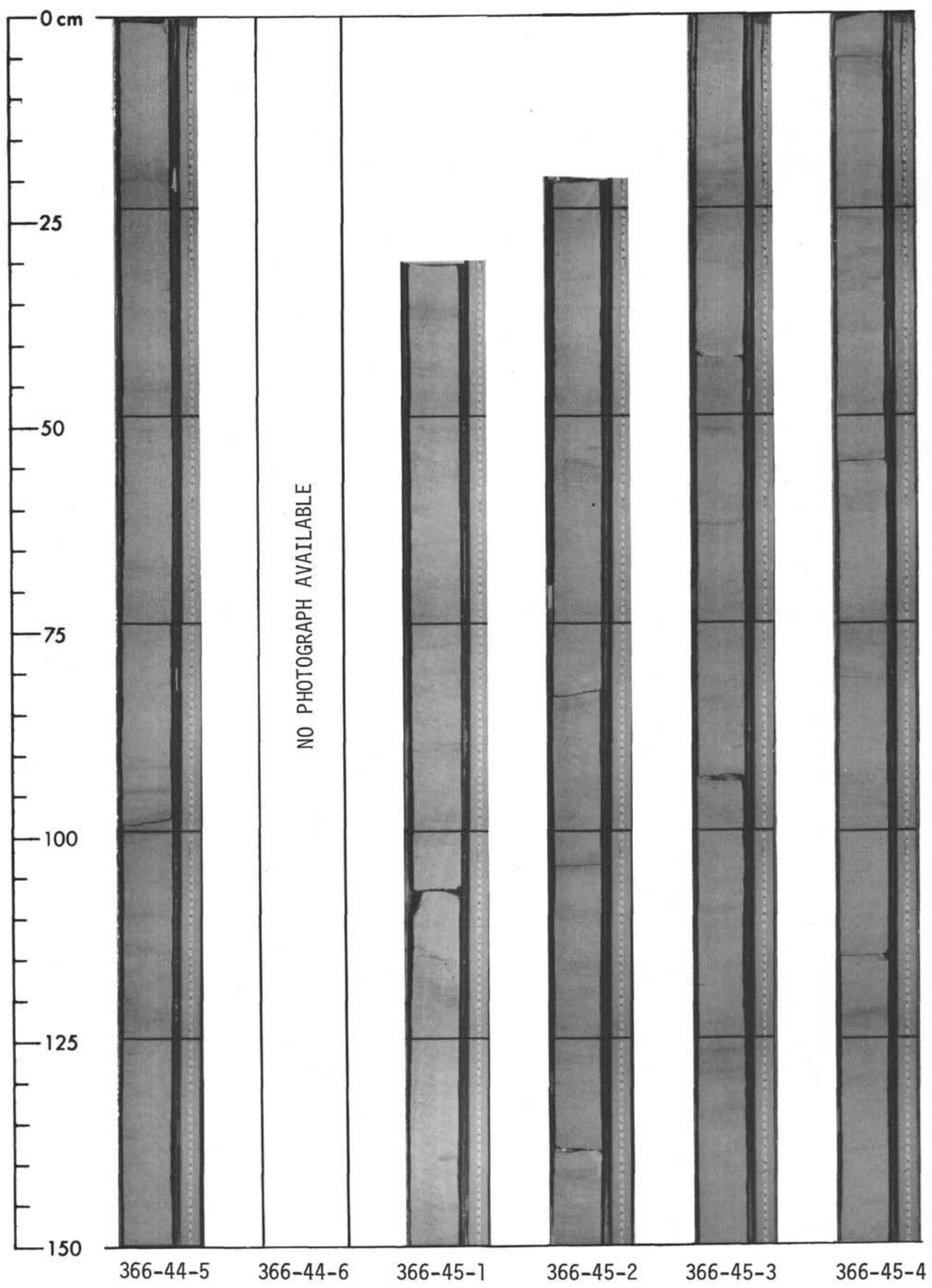




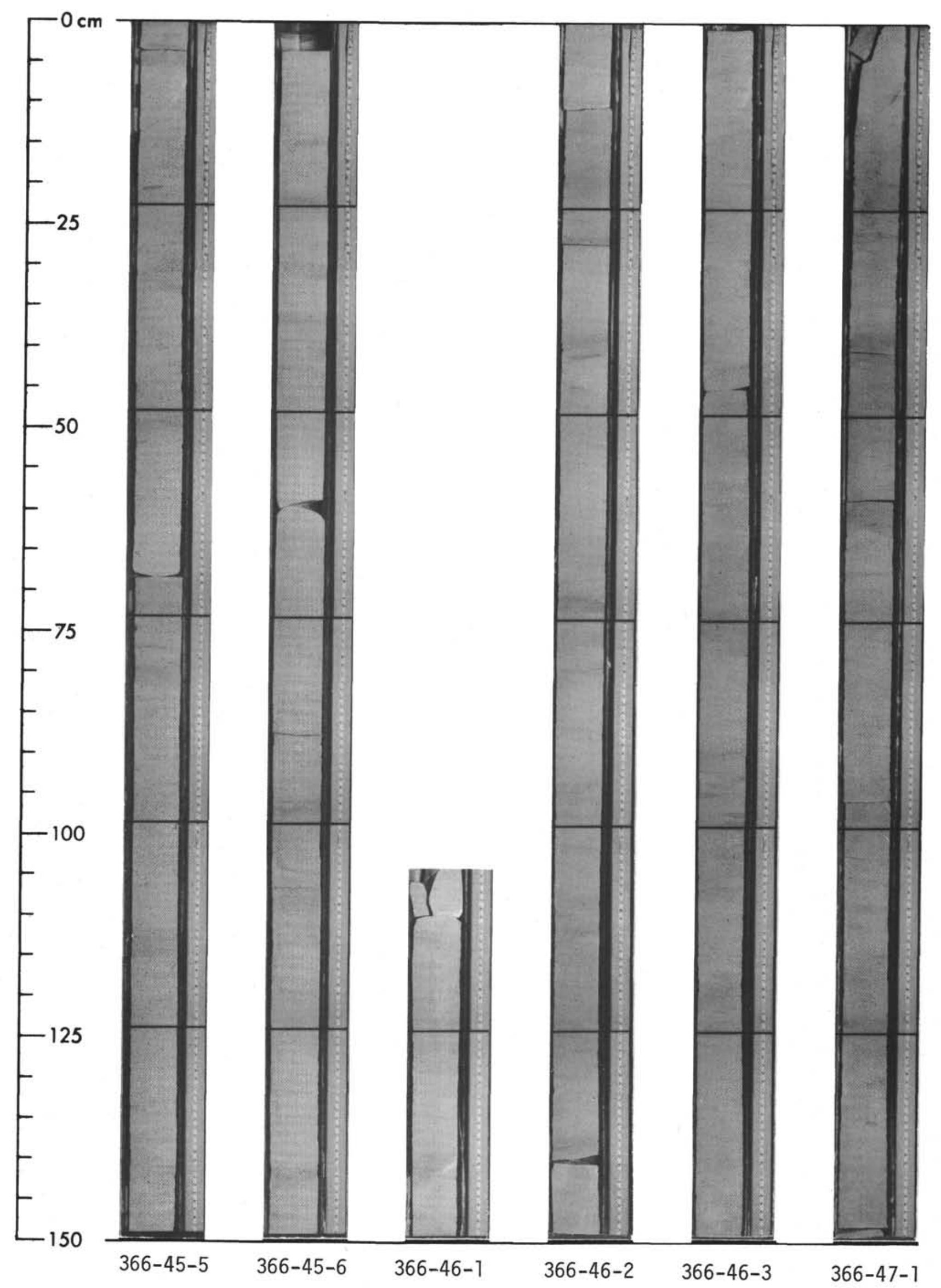




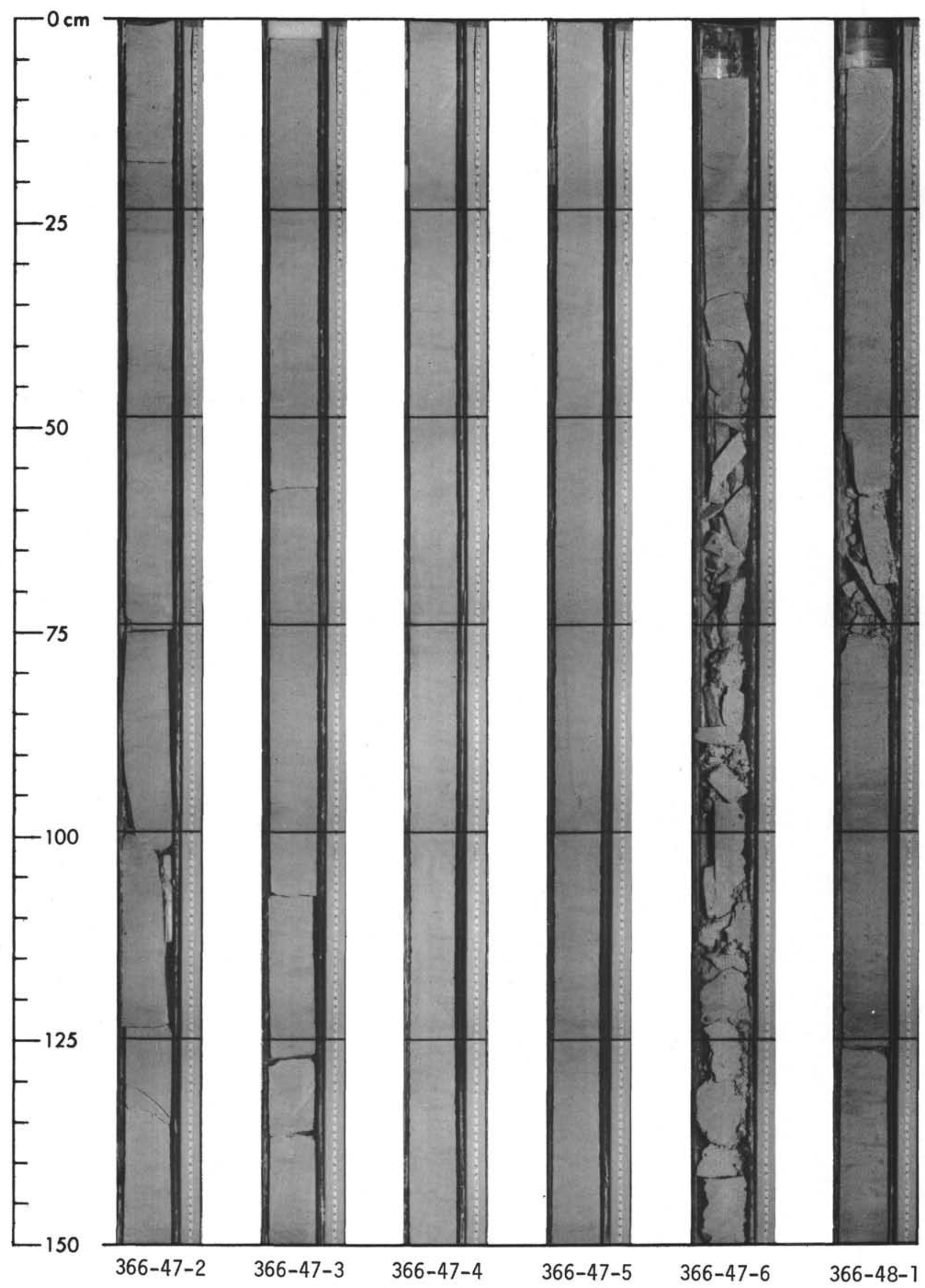




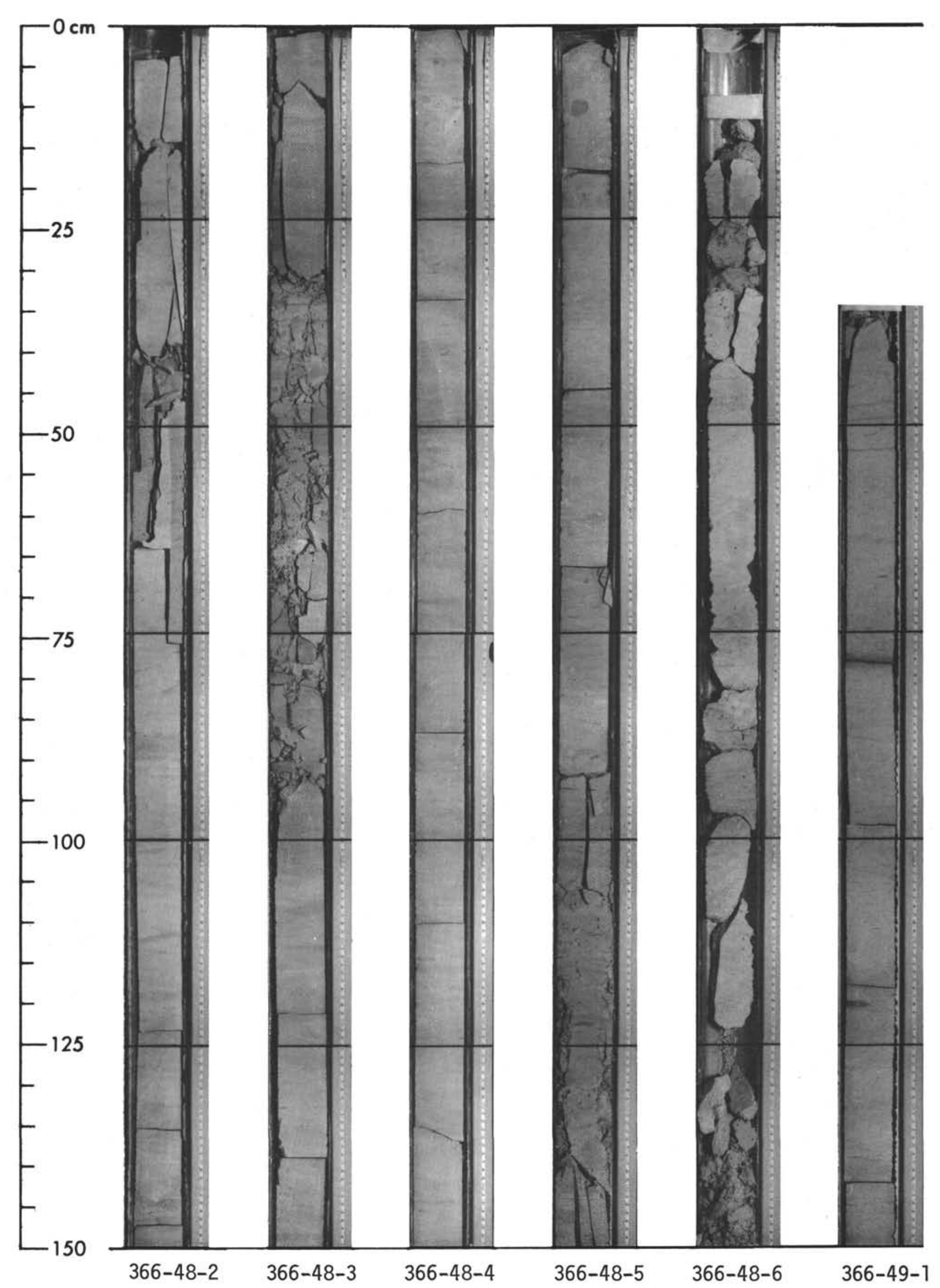




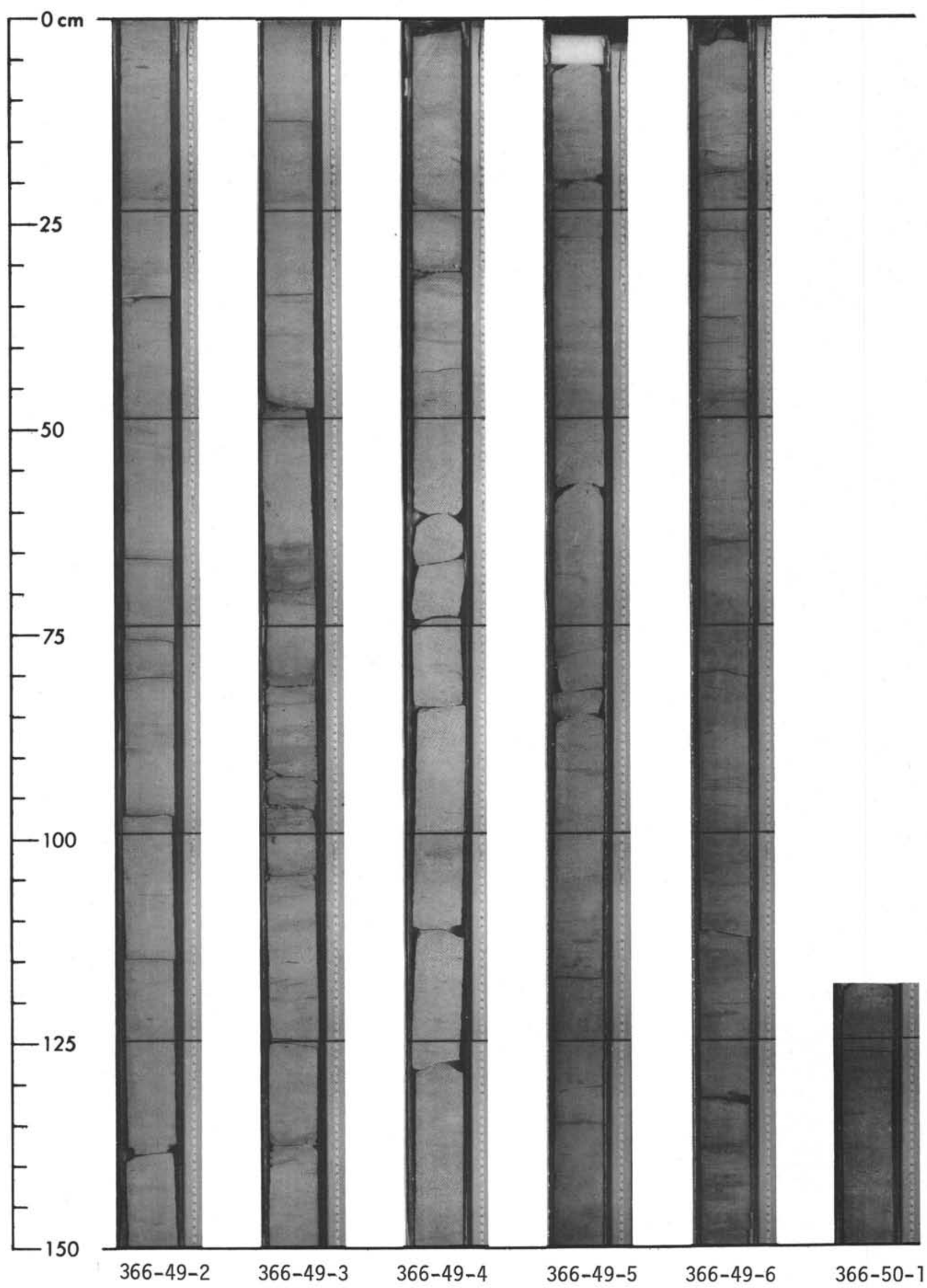




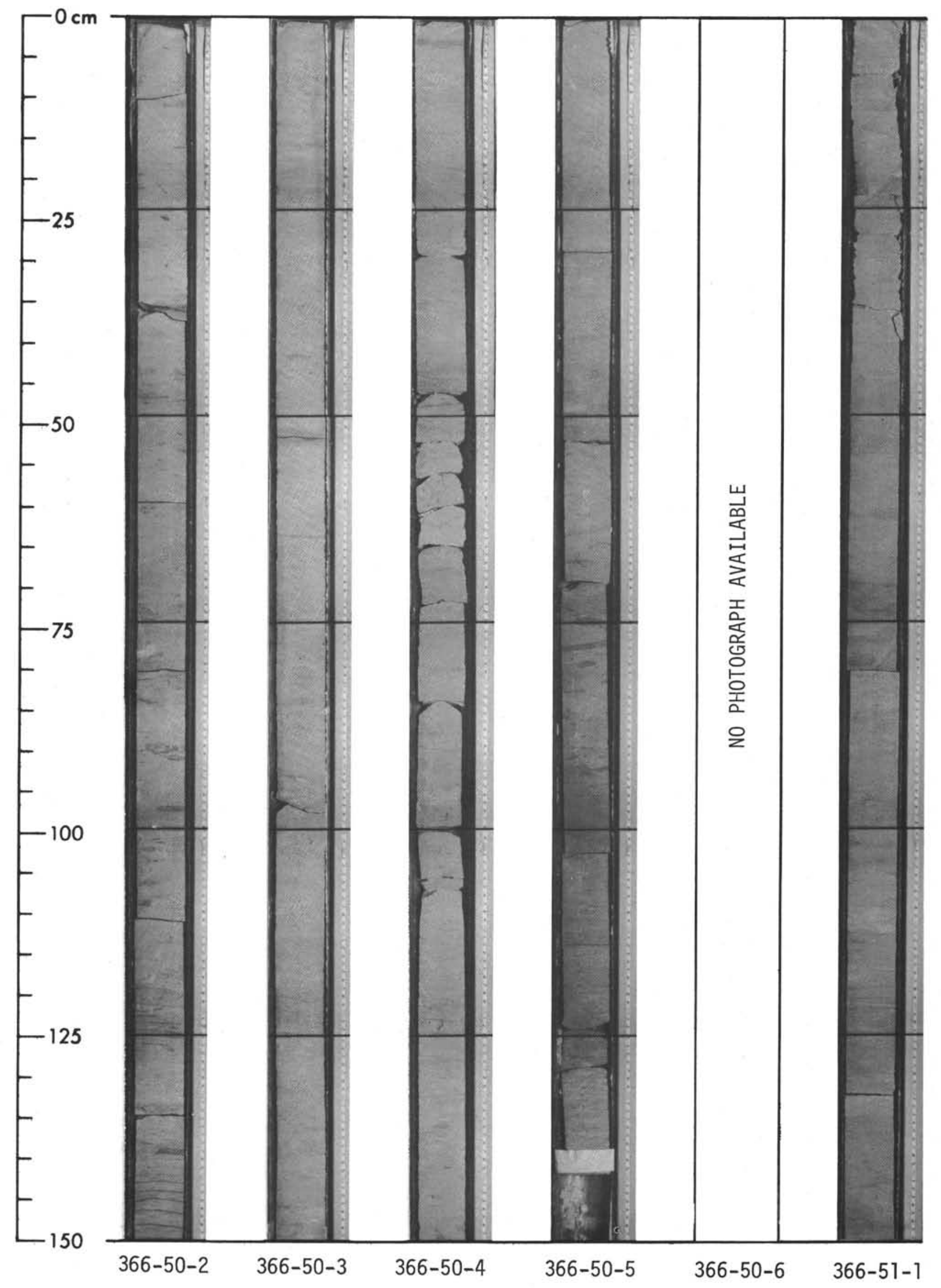




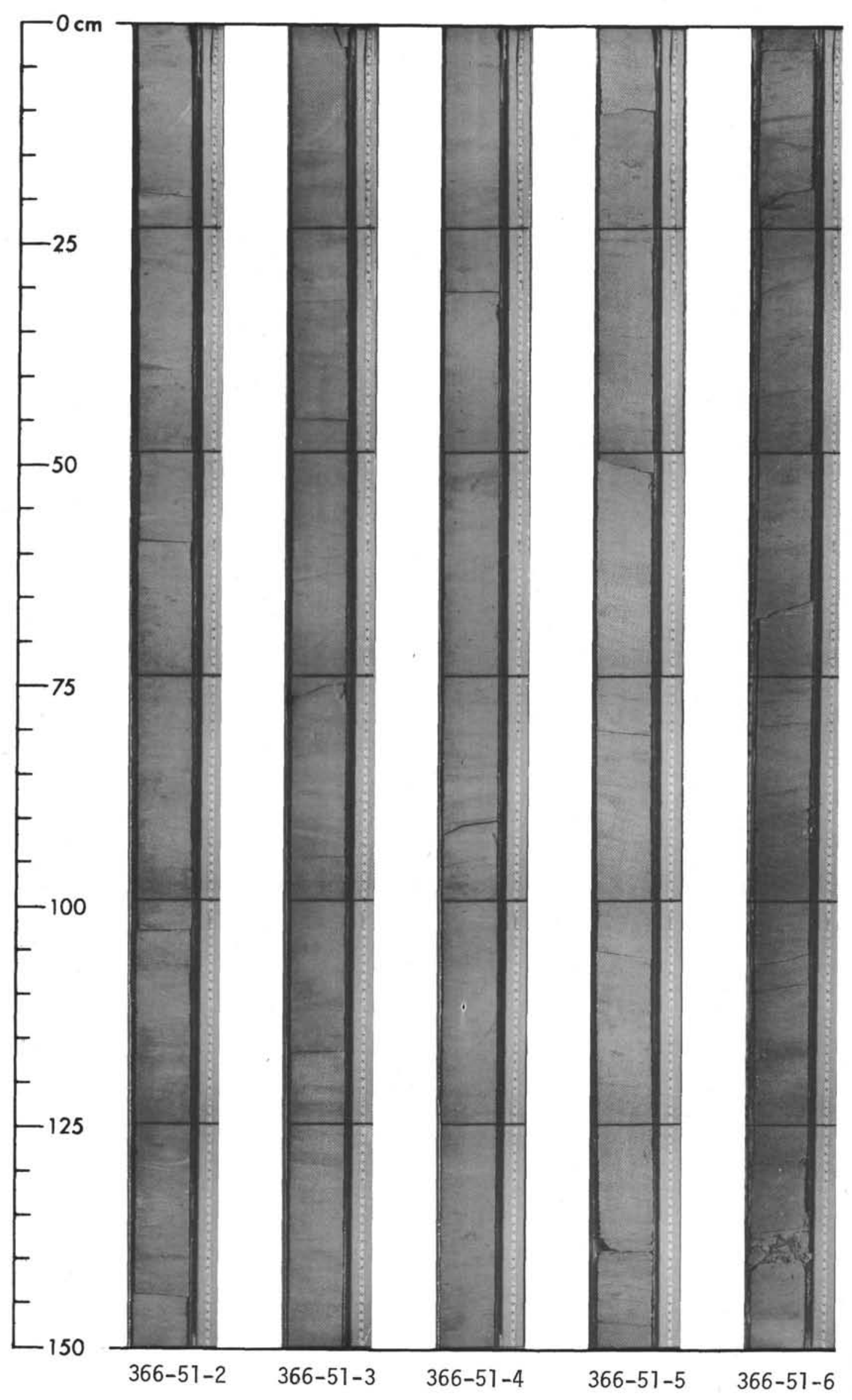




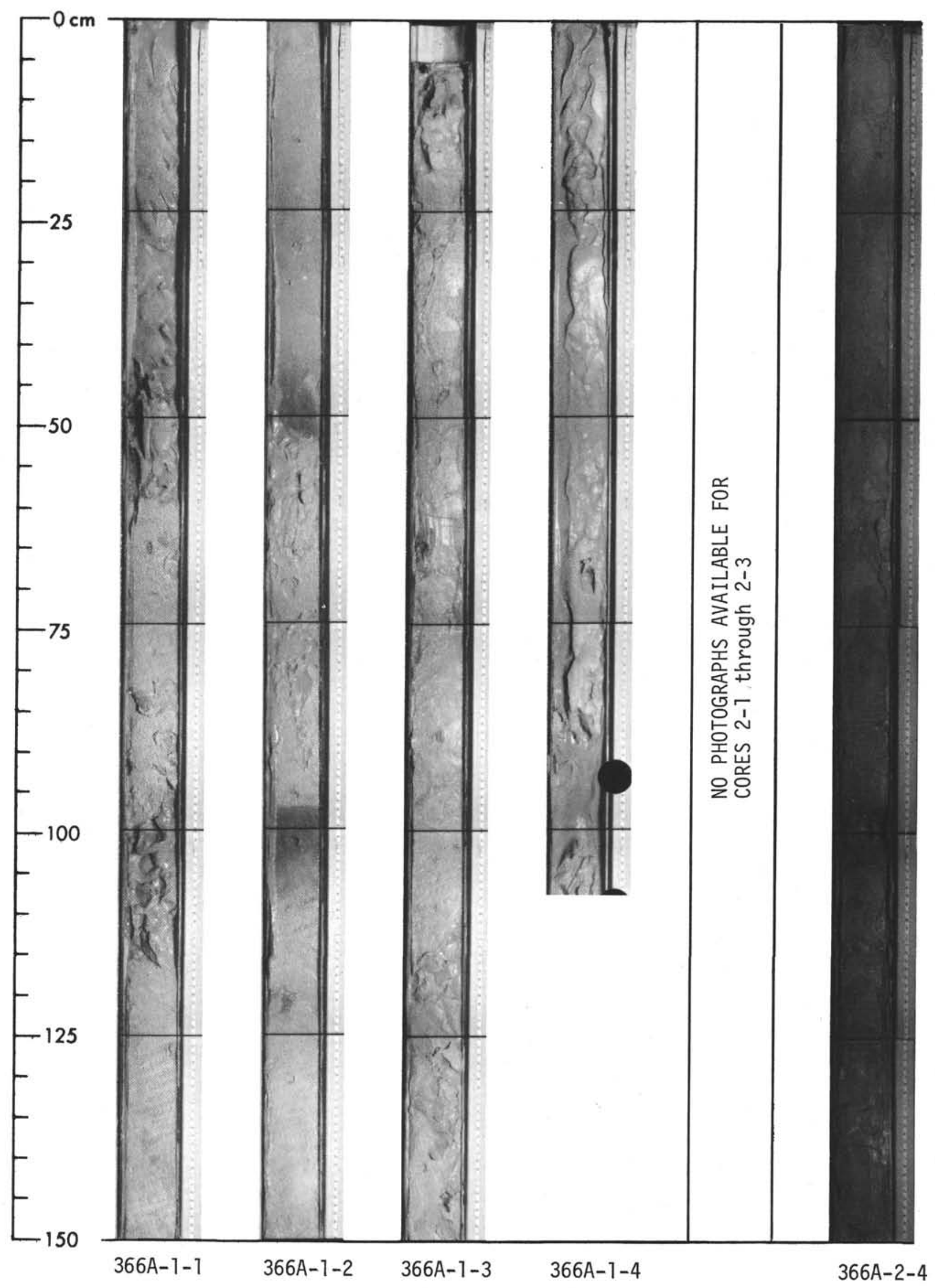




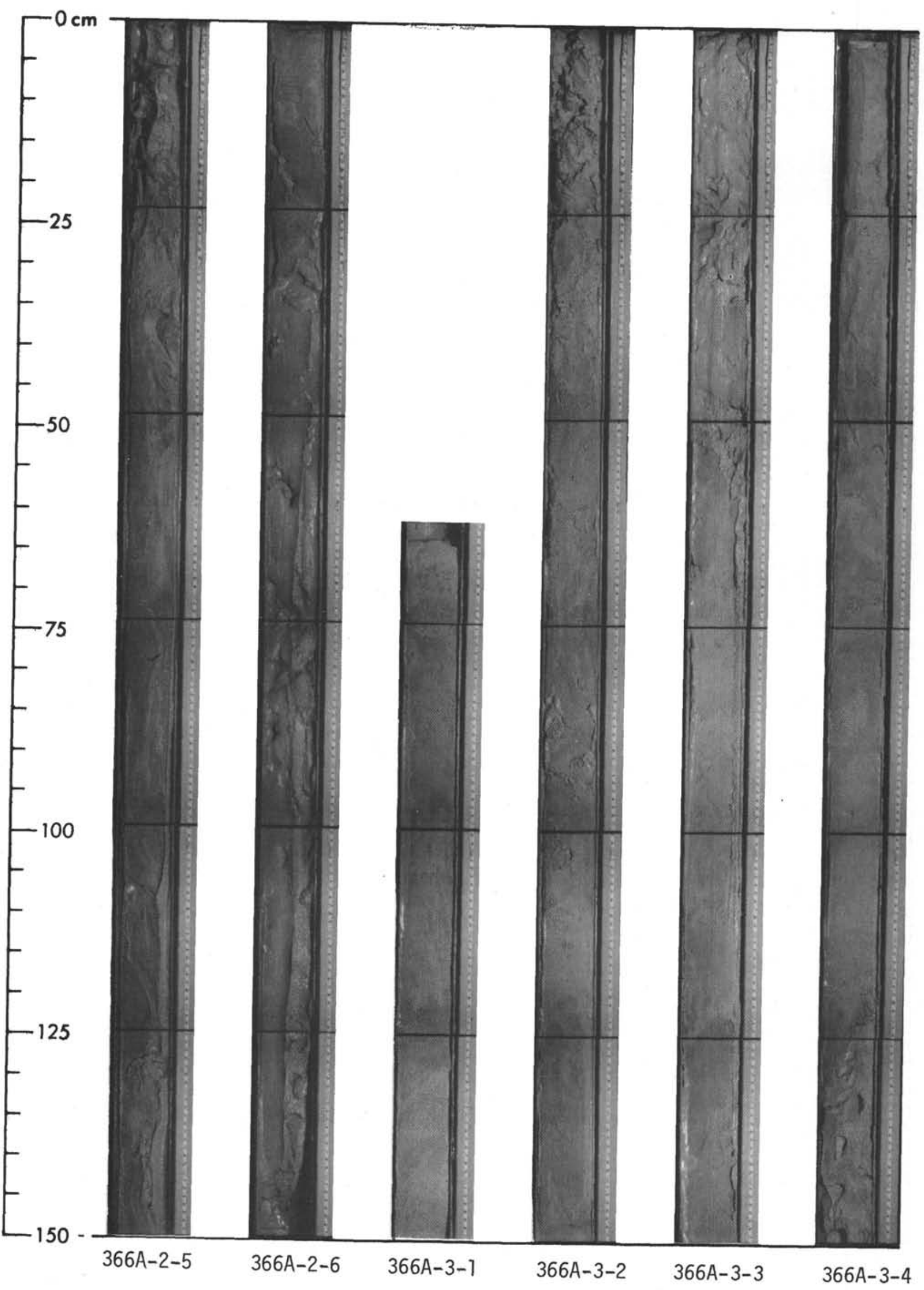




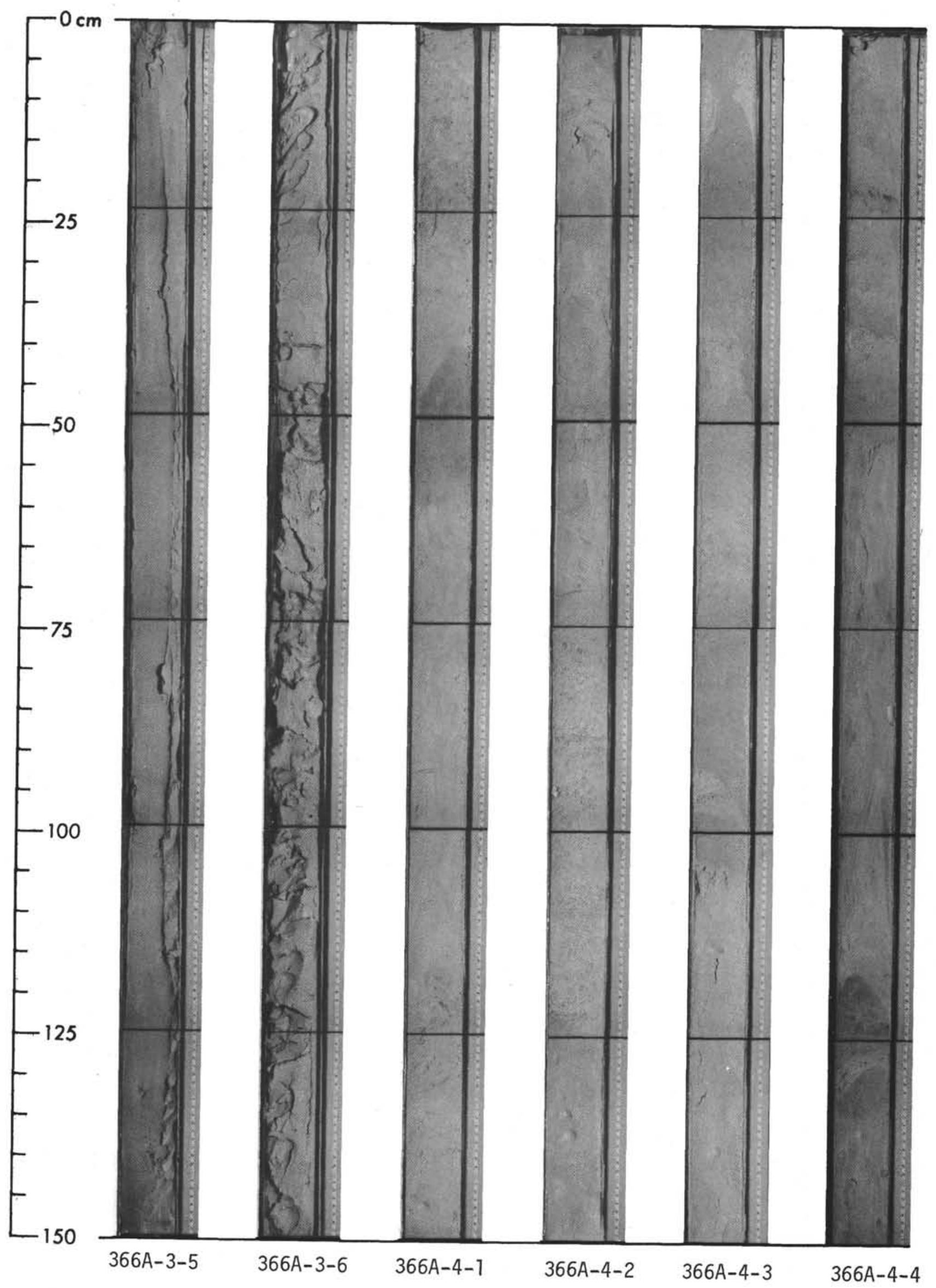




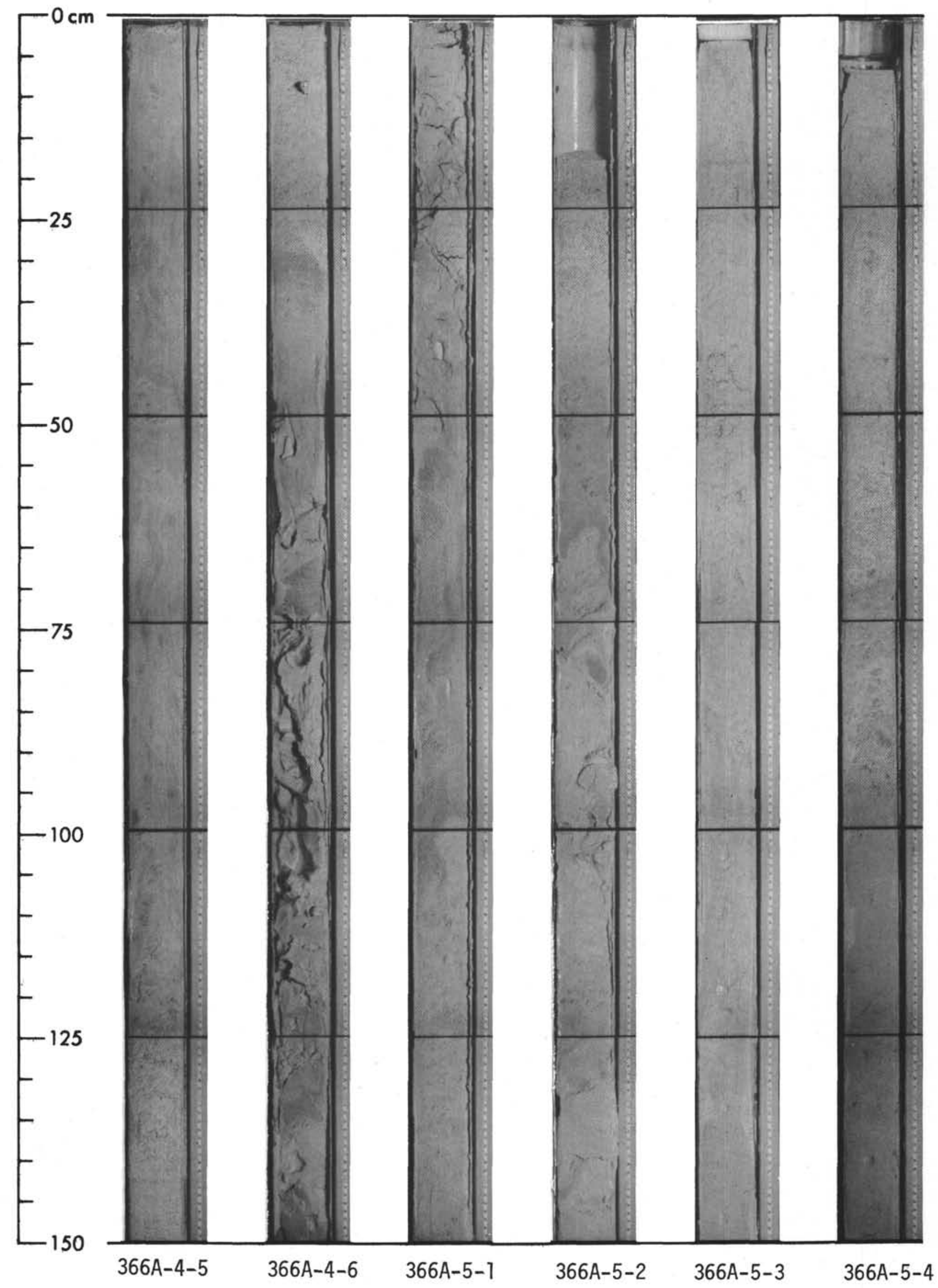


SITE 366: SIERRA LEONE RISE

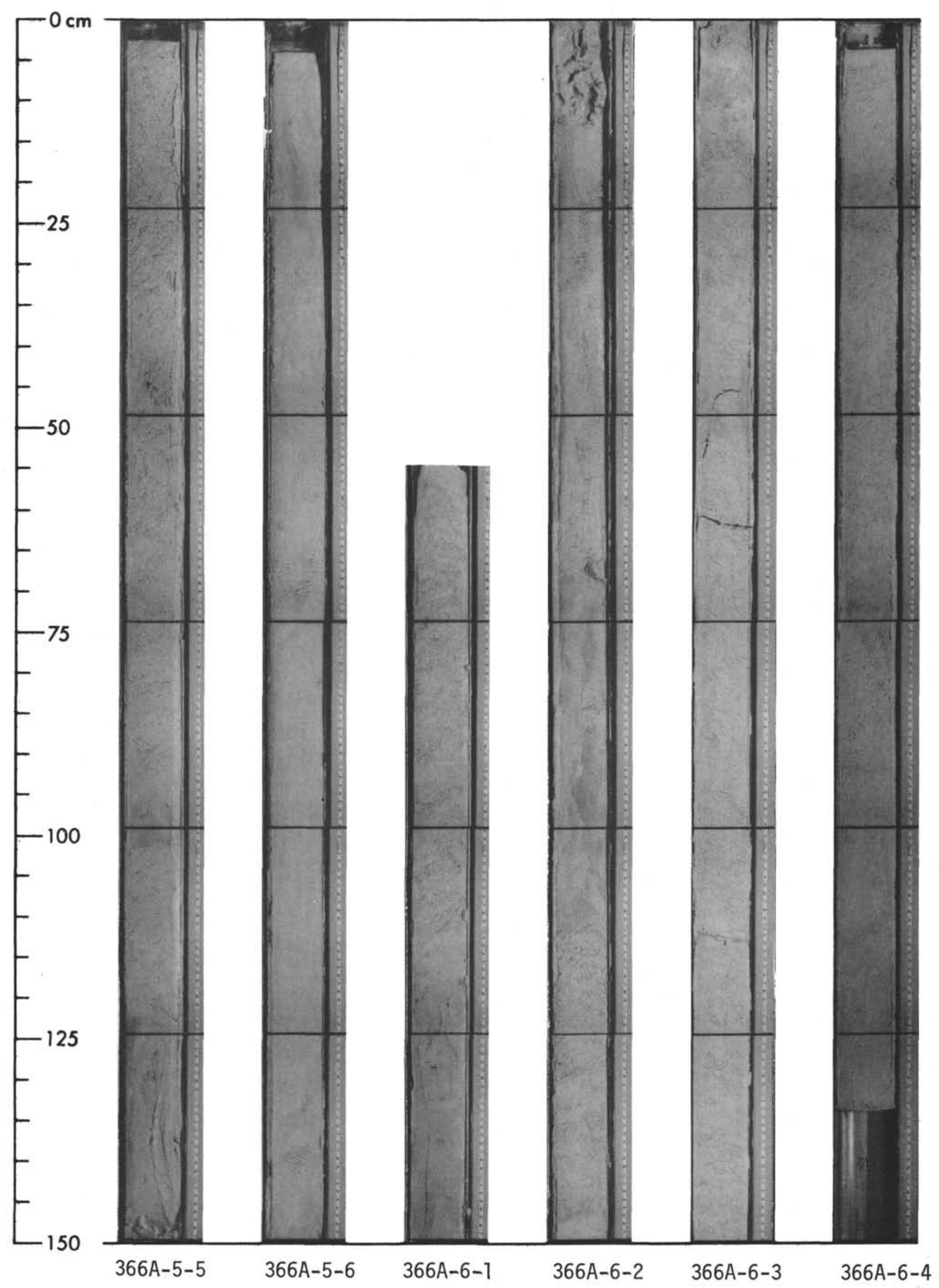




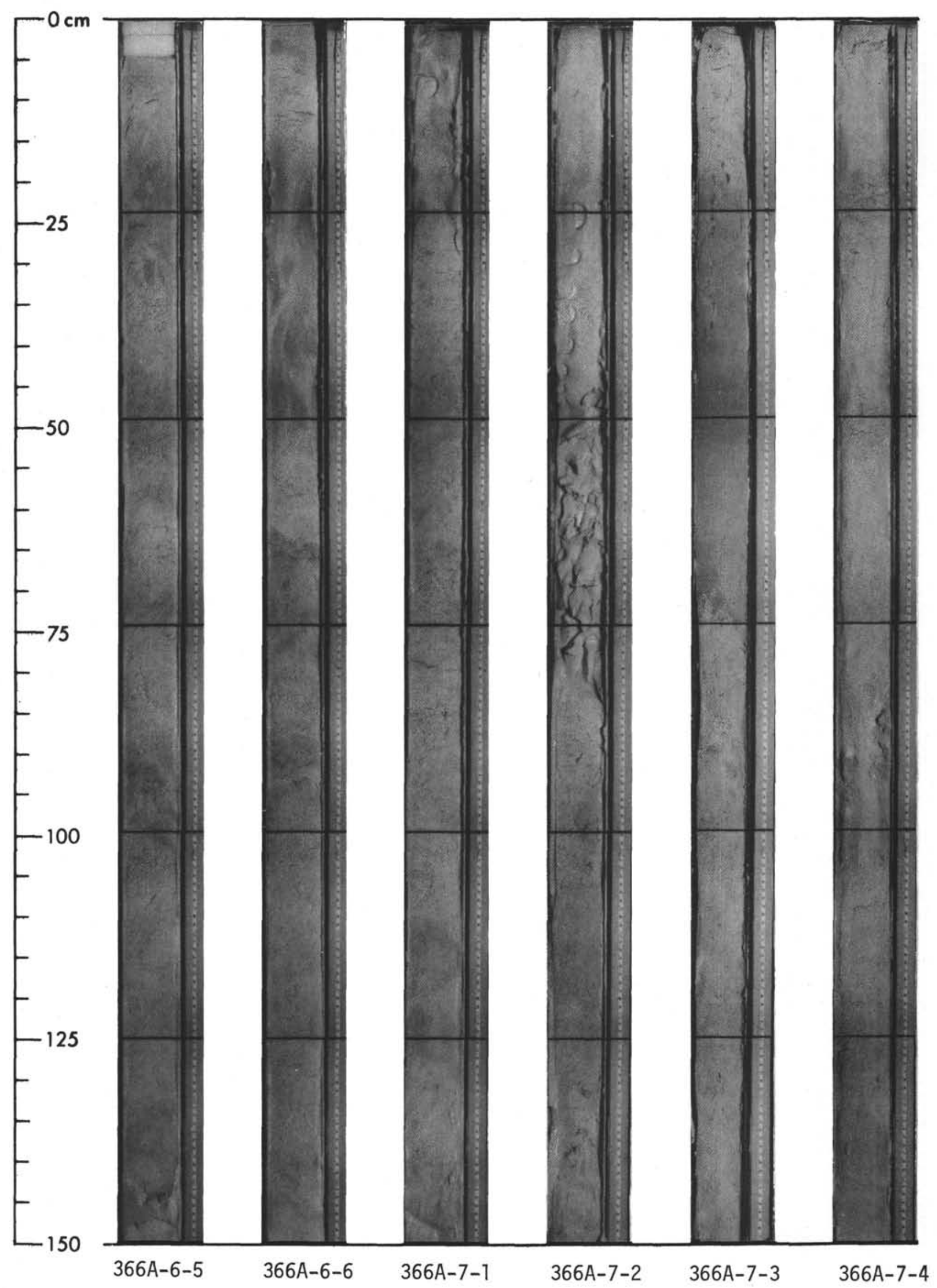




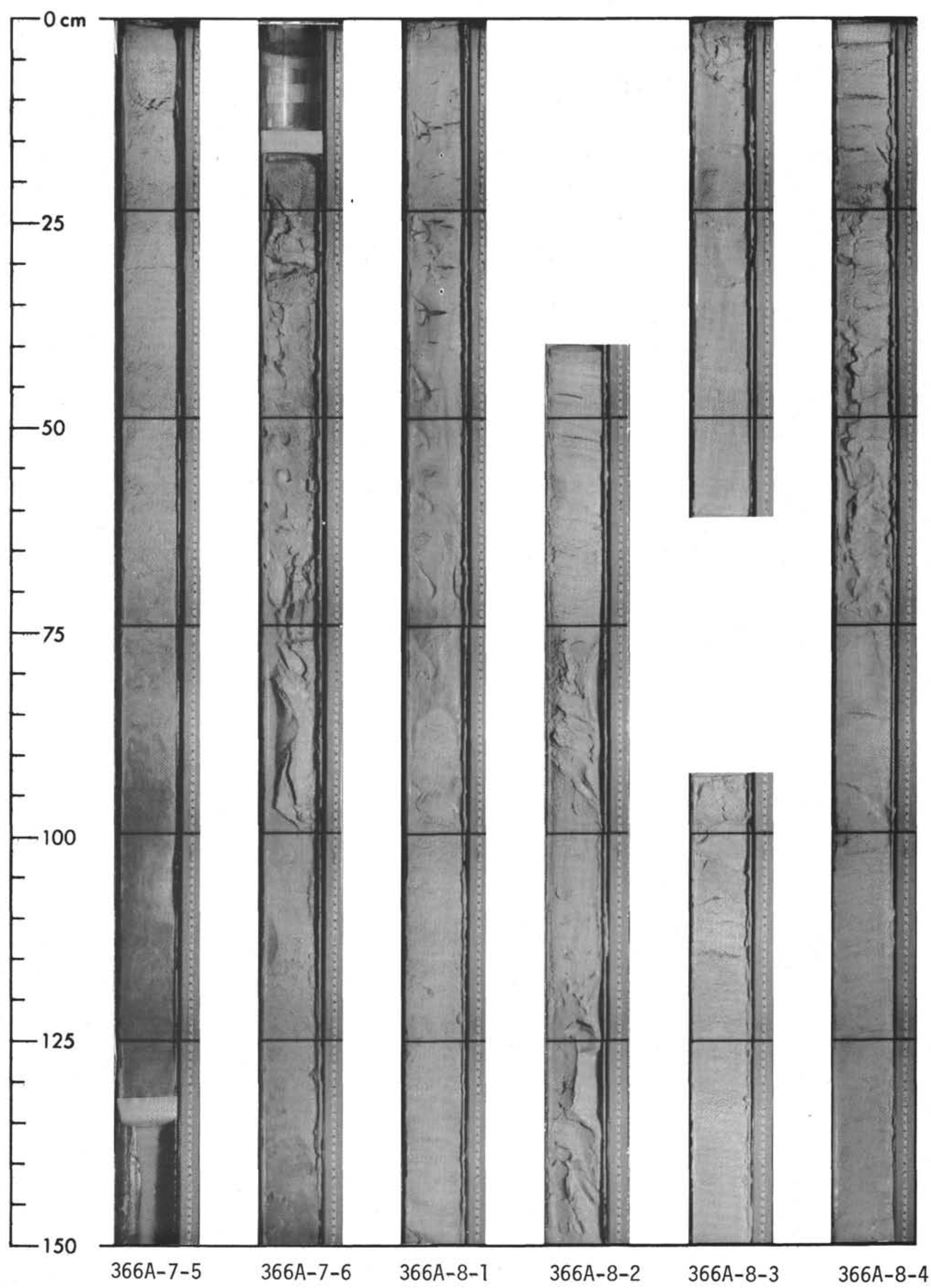




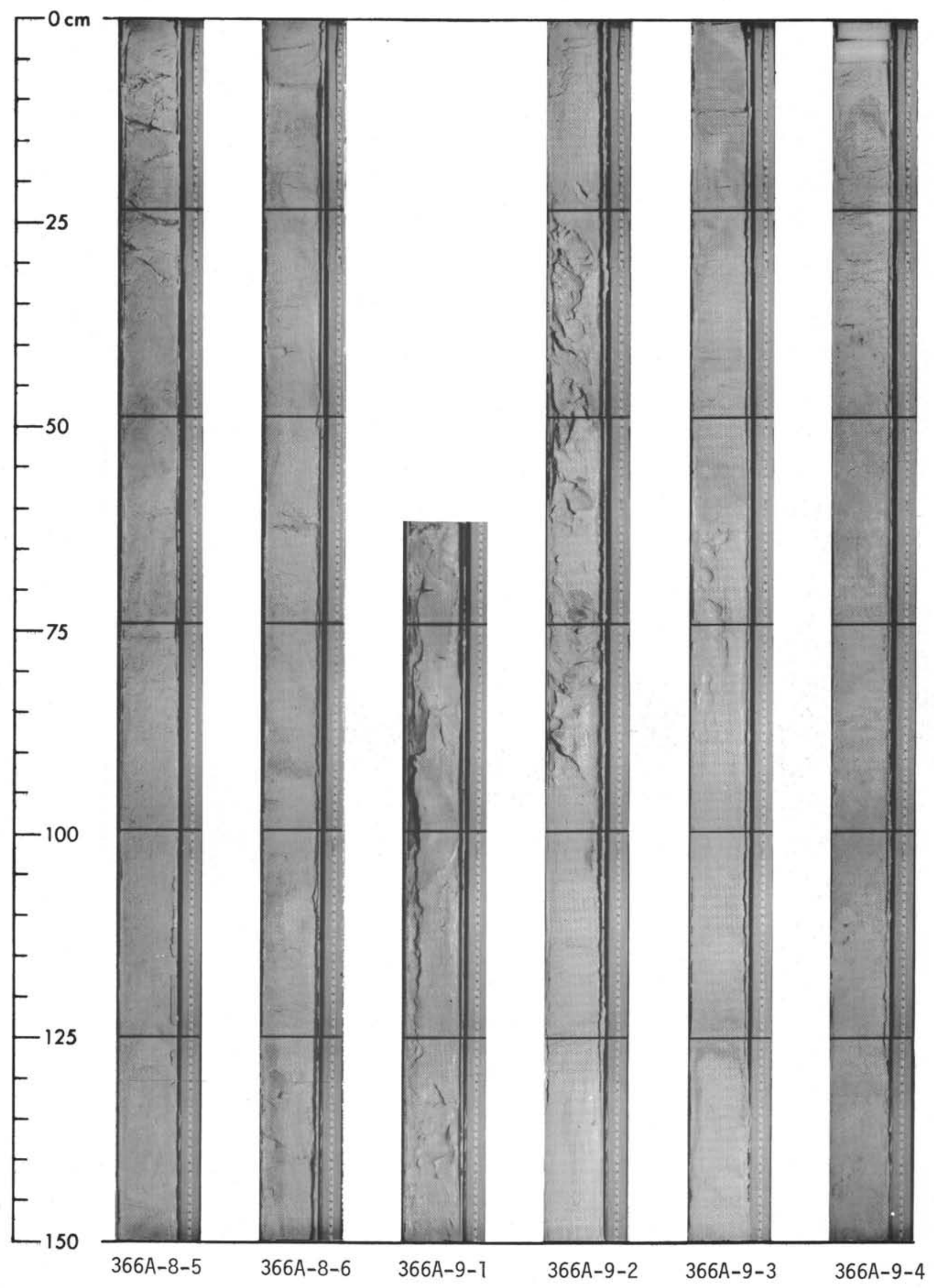




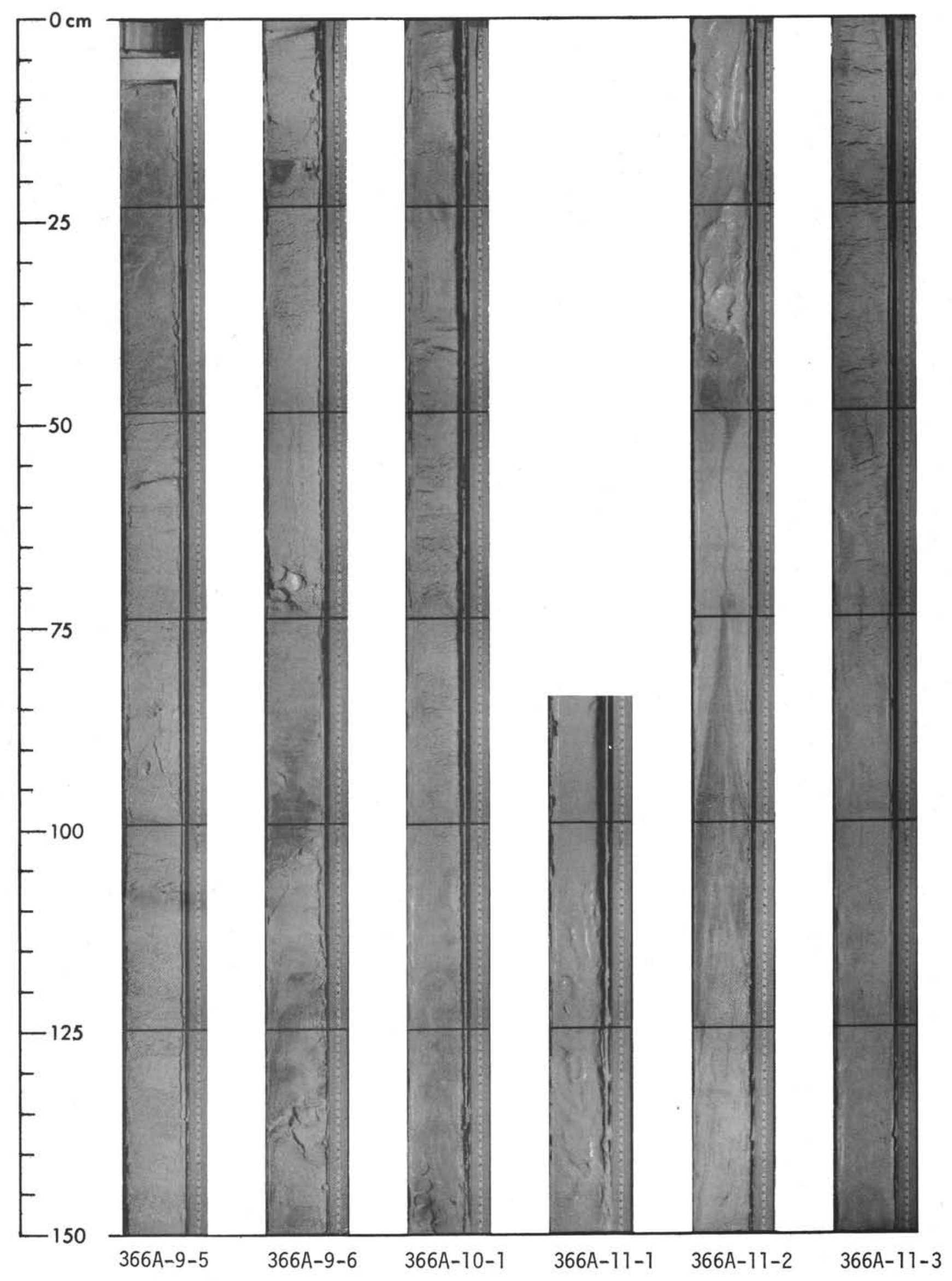




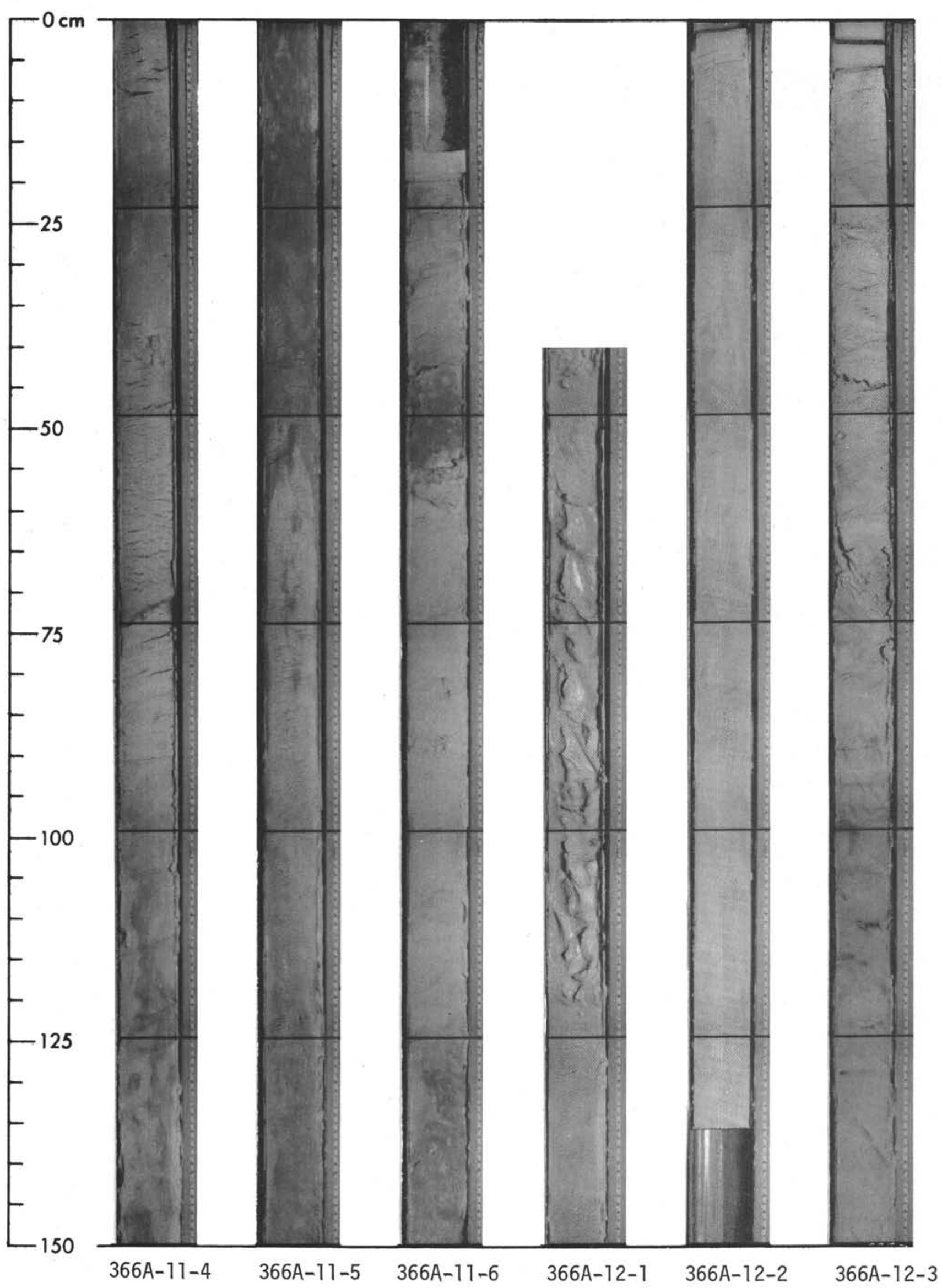




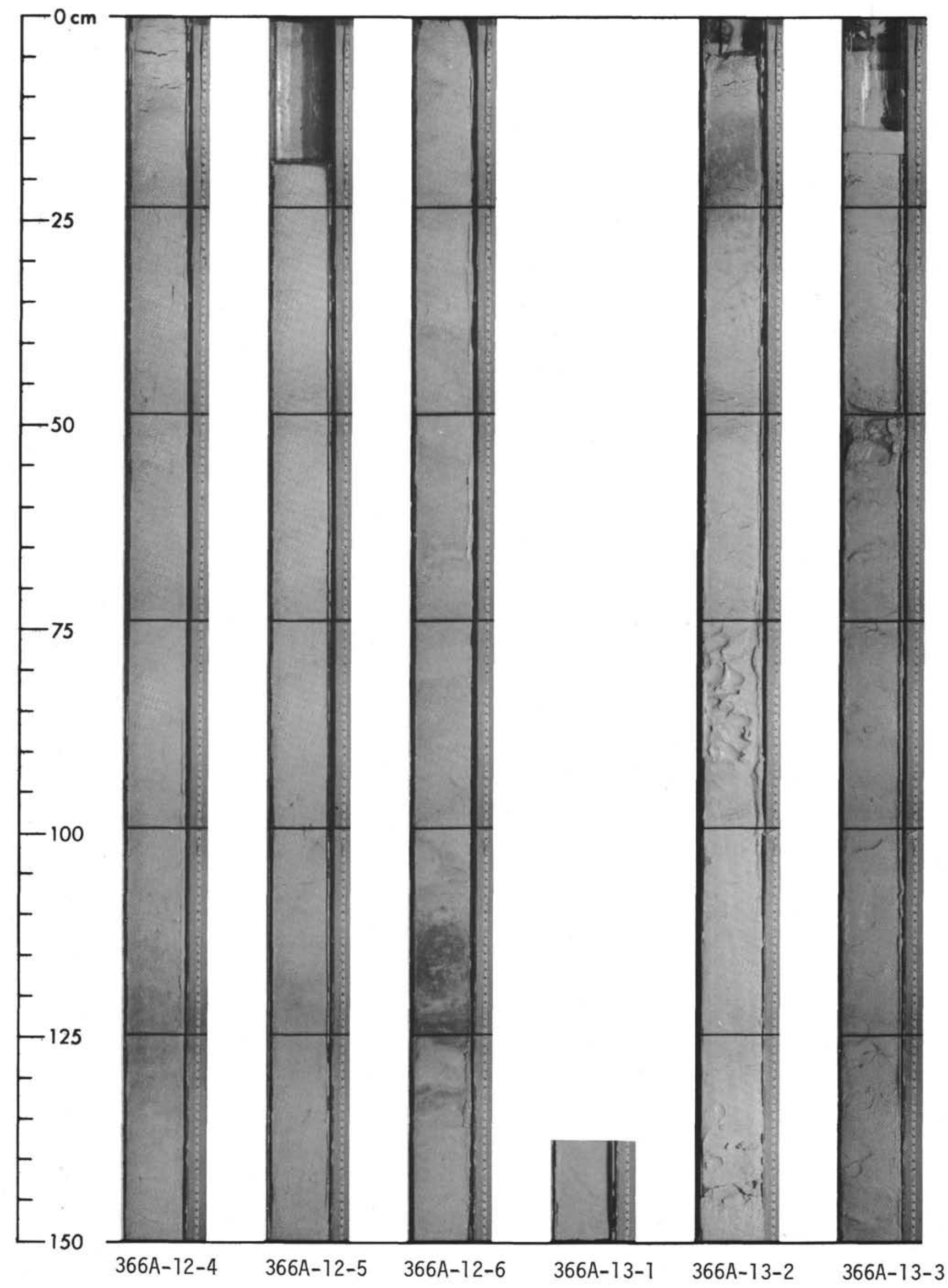




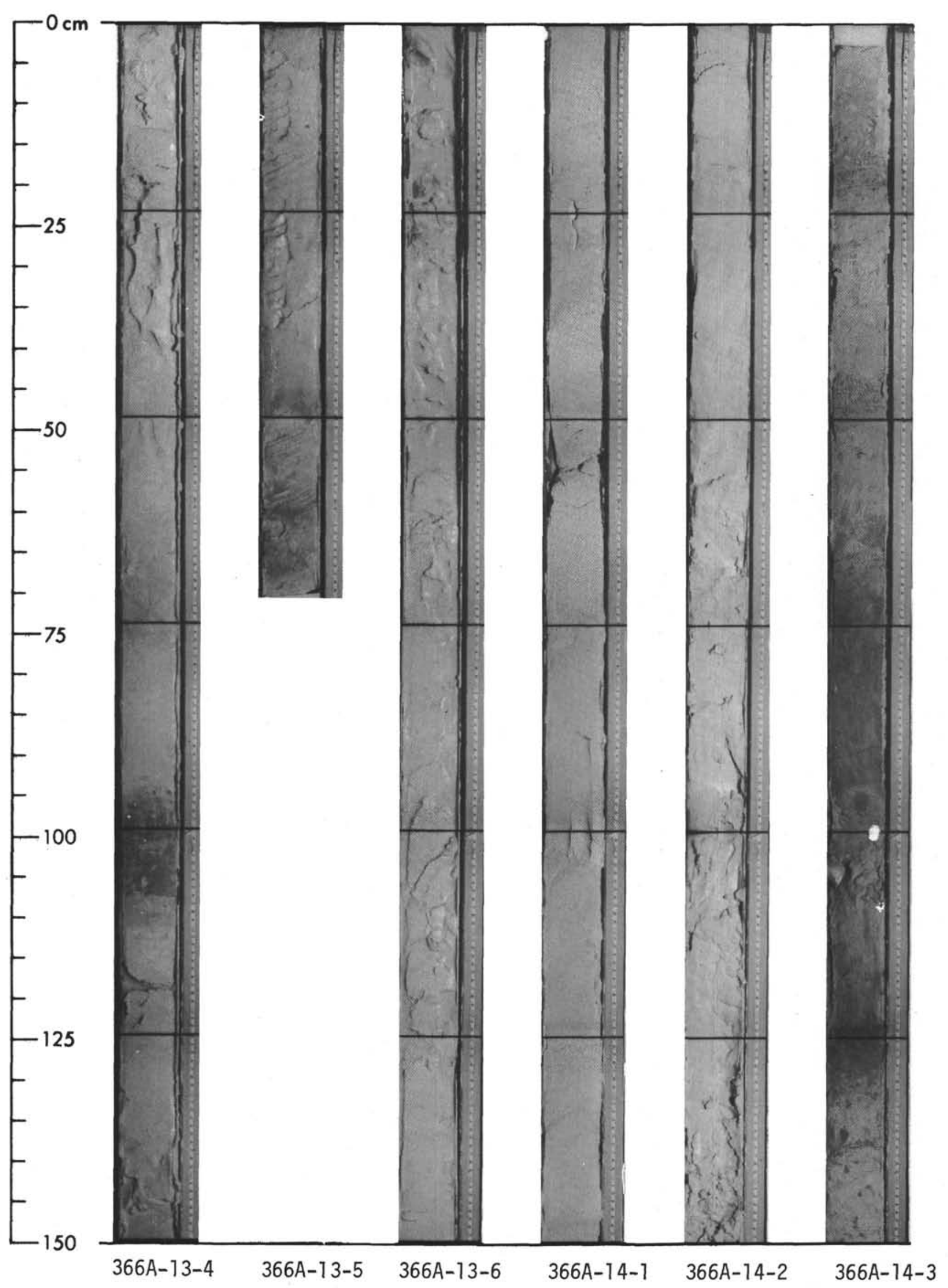




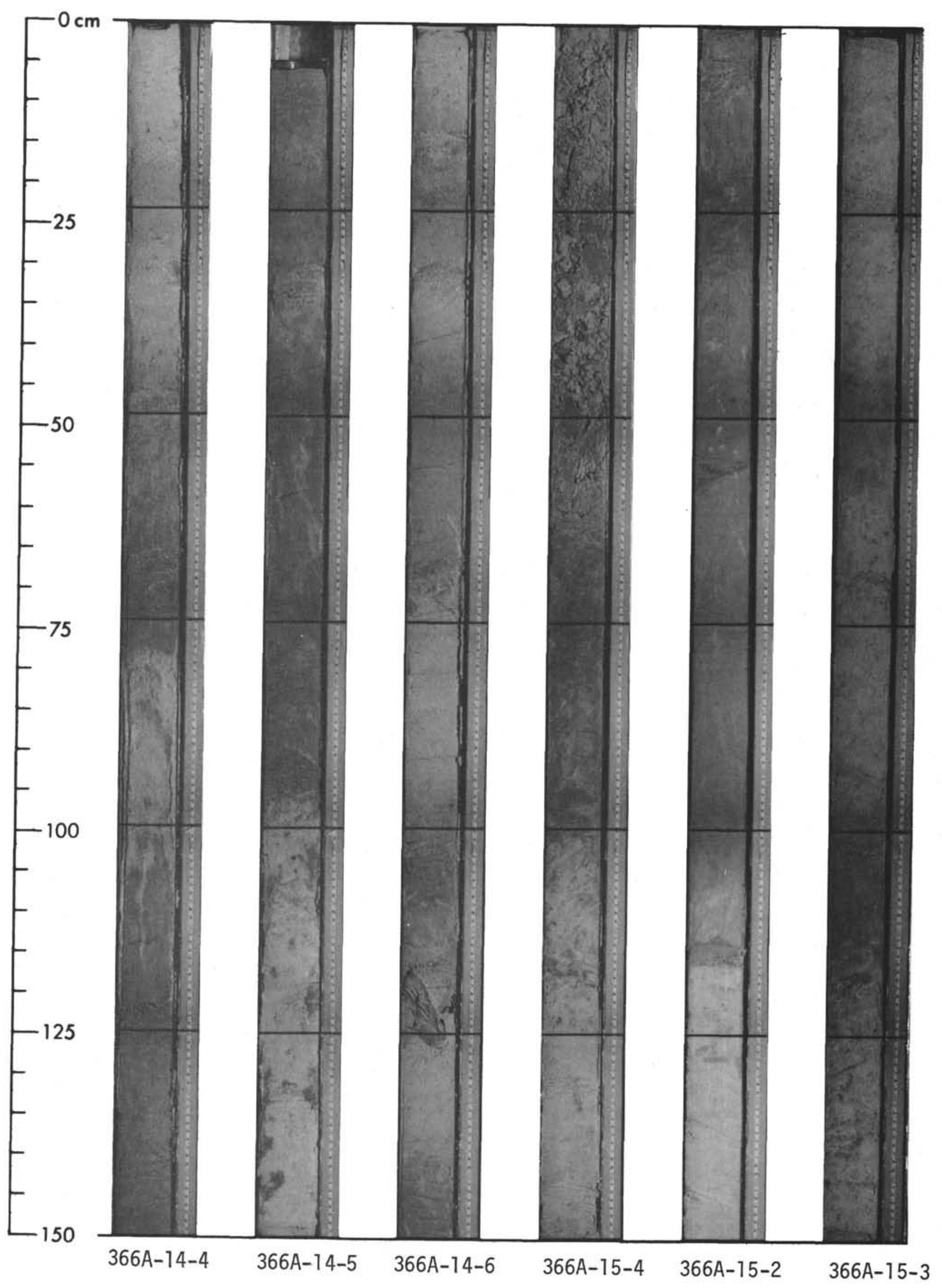




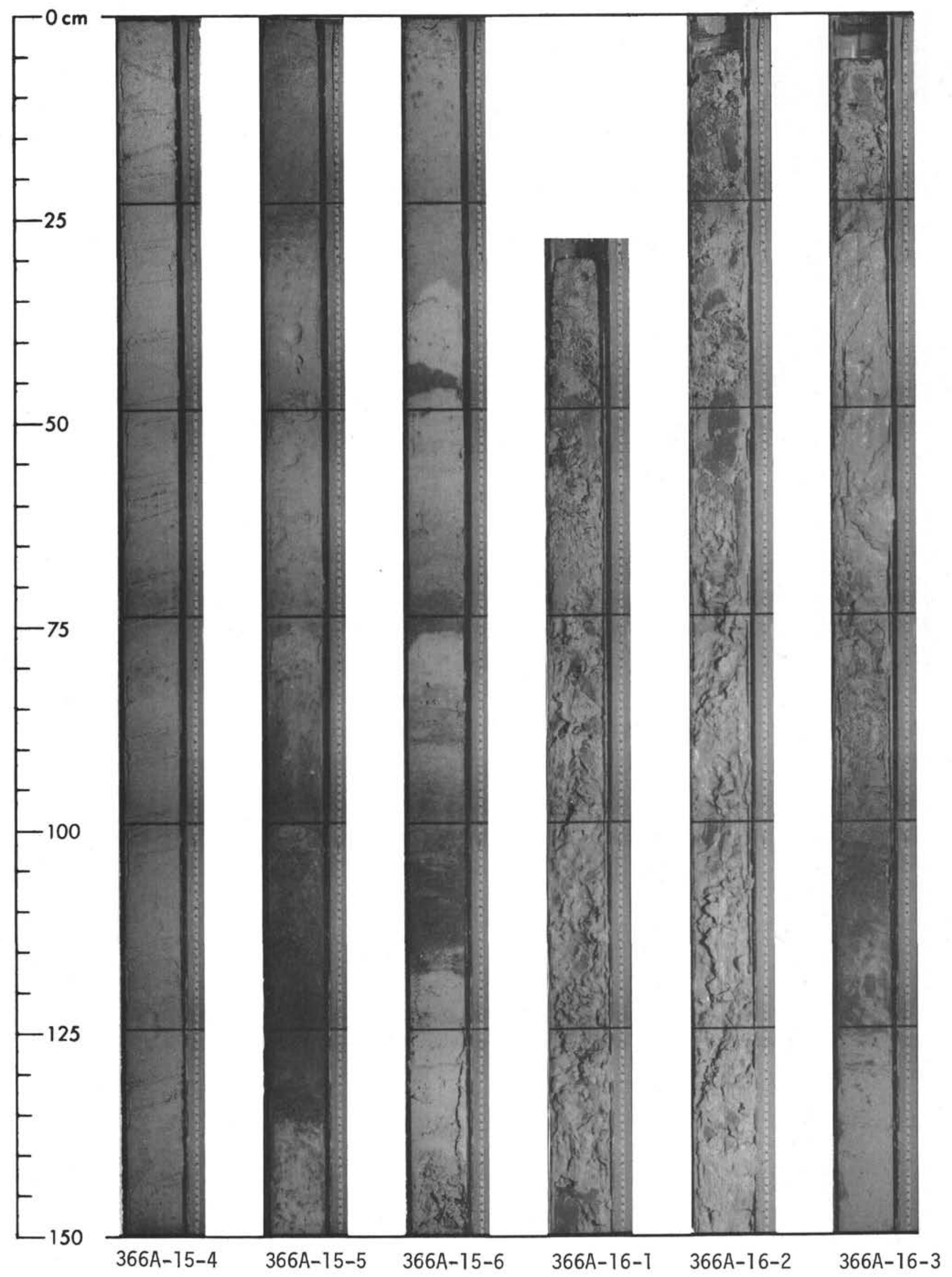




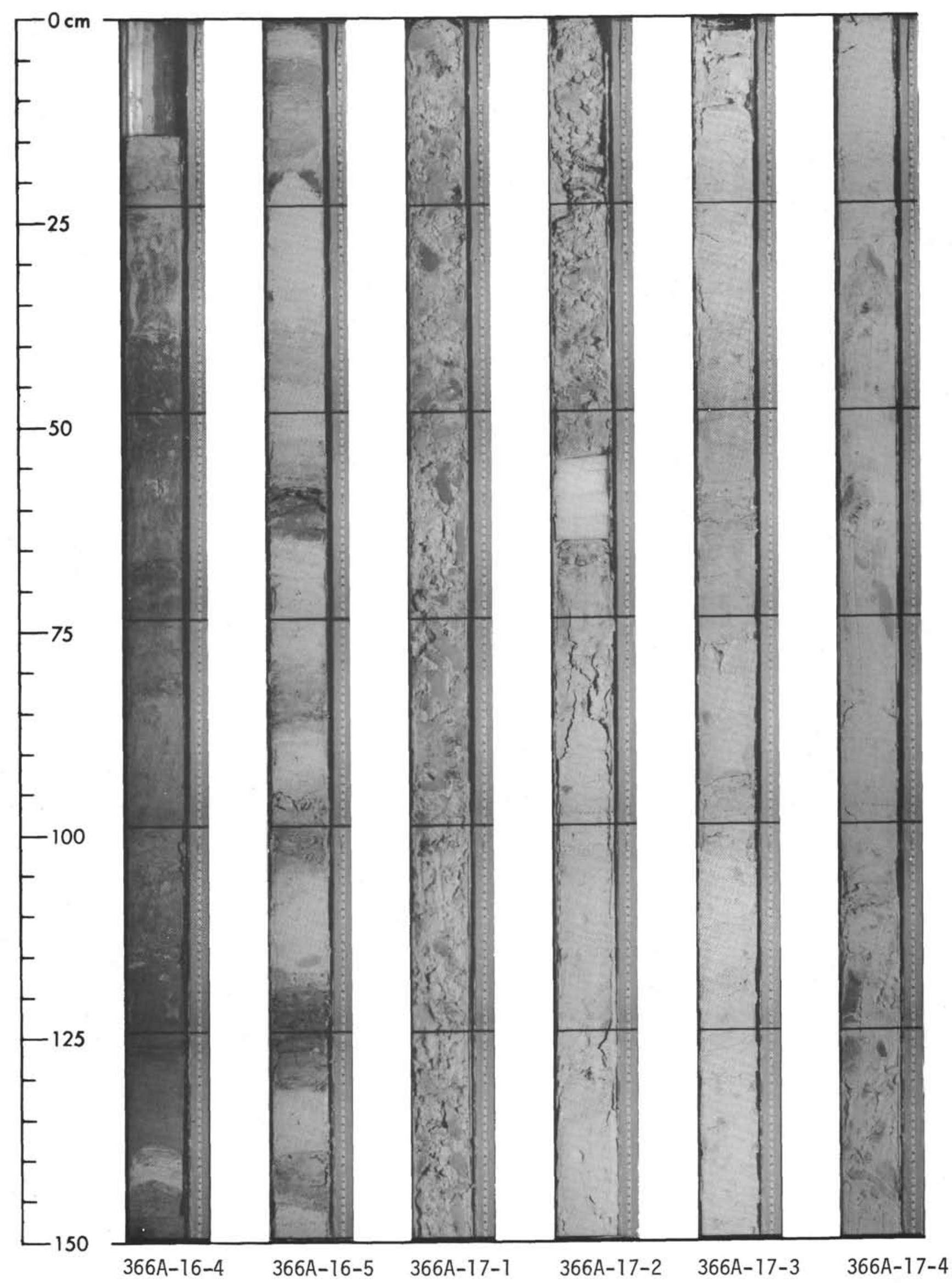




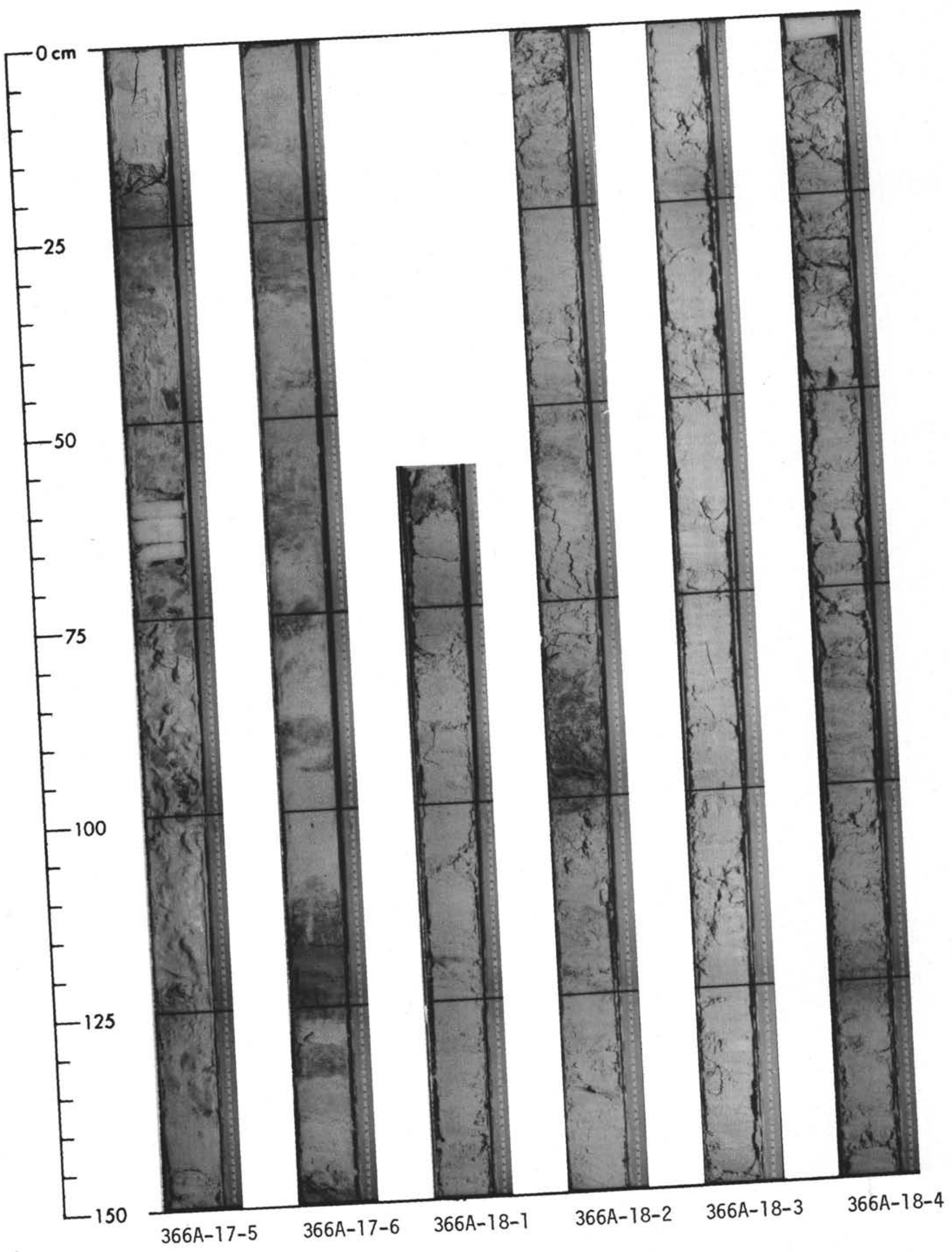




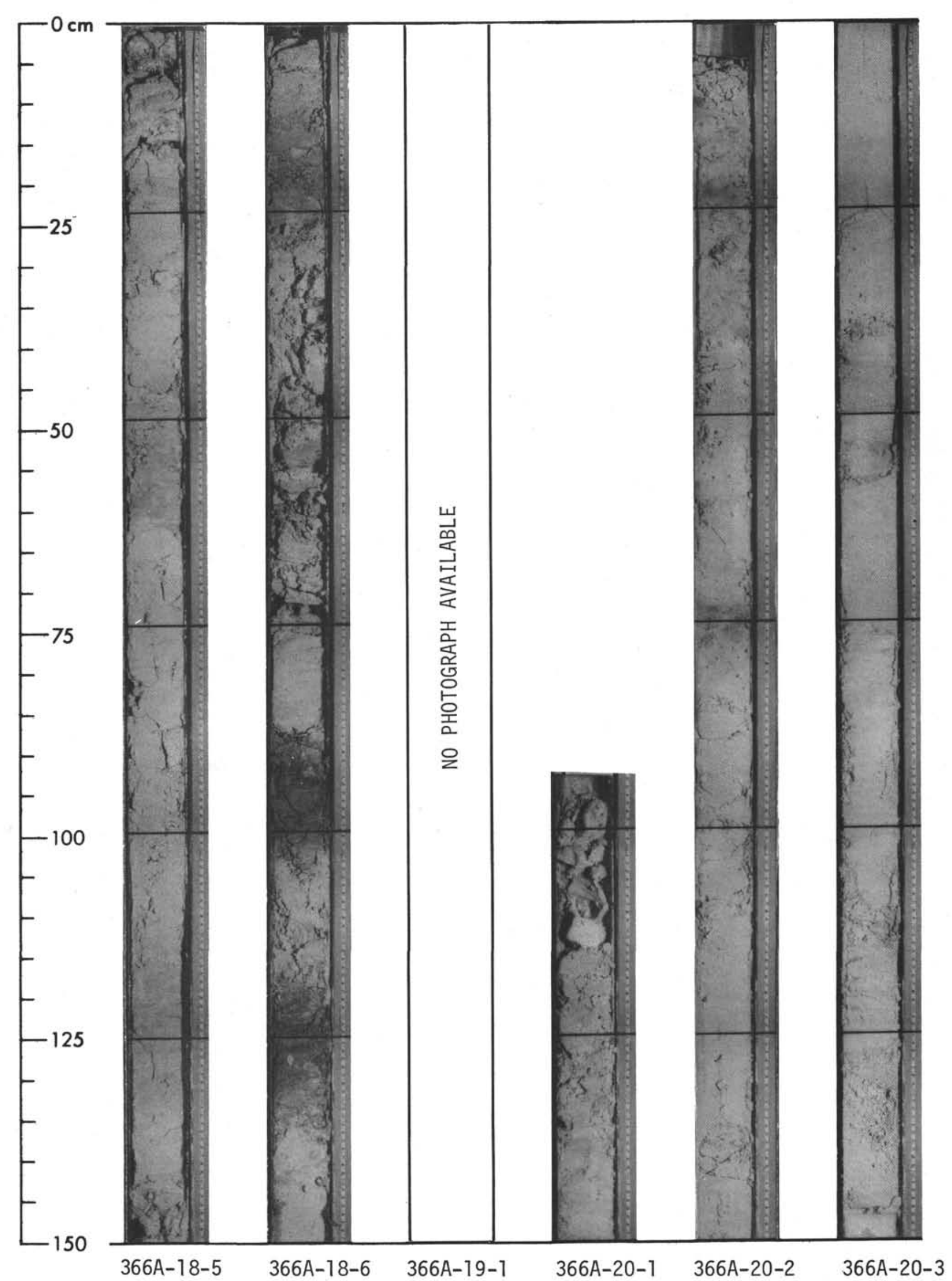




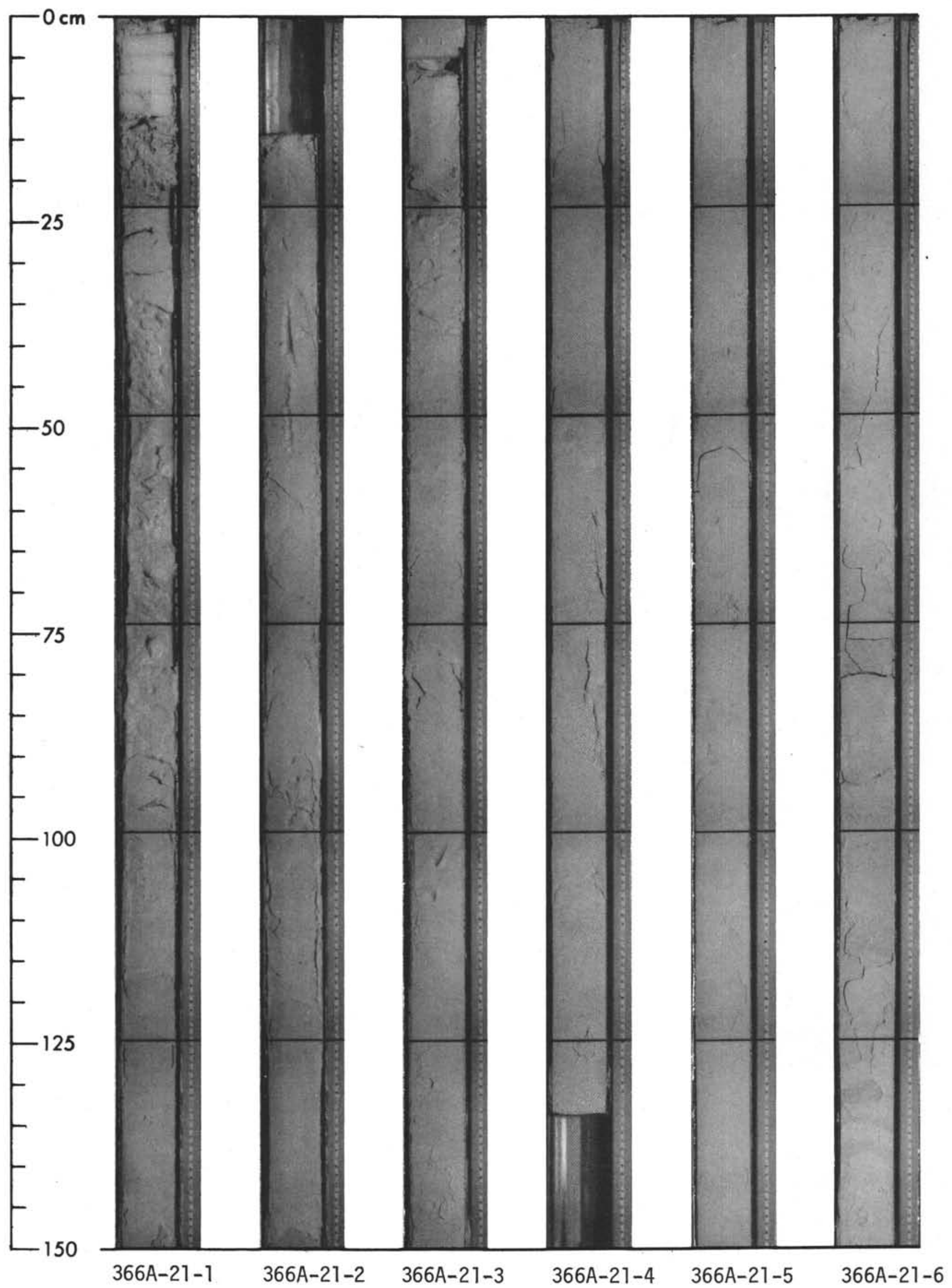




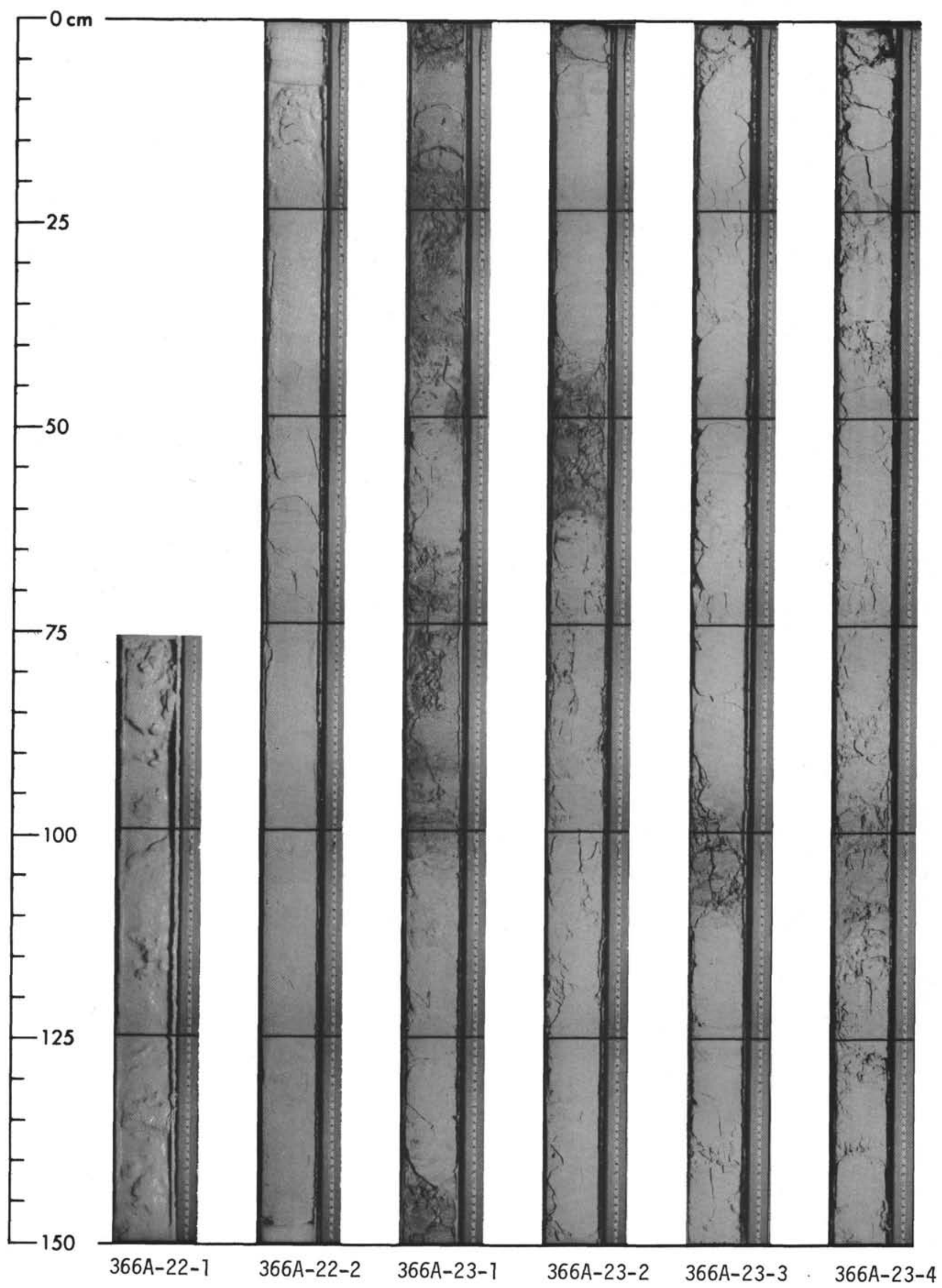




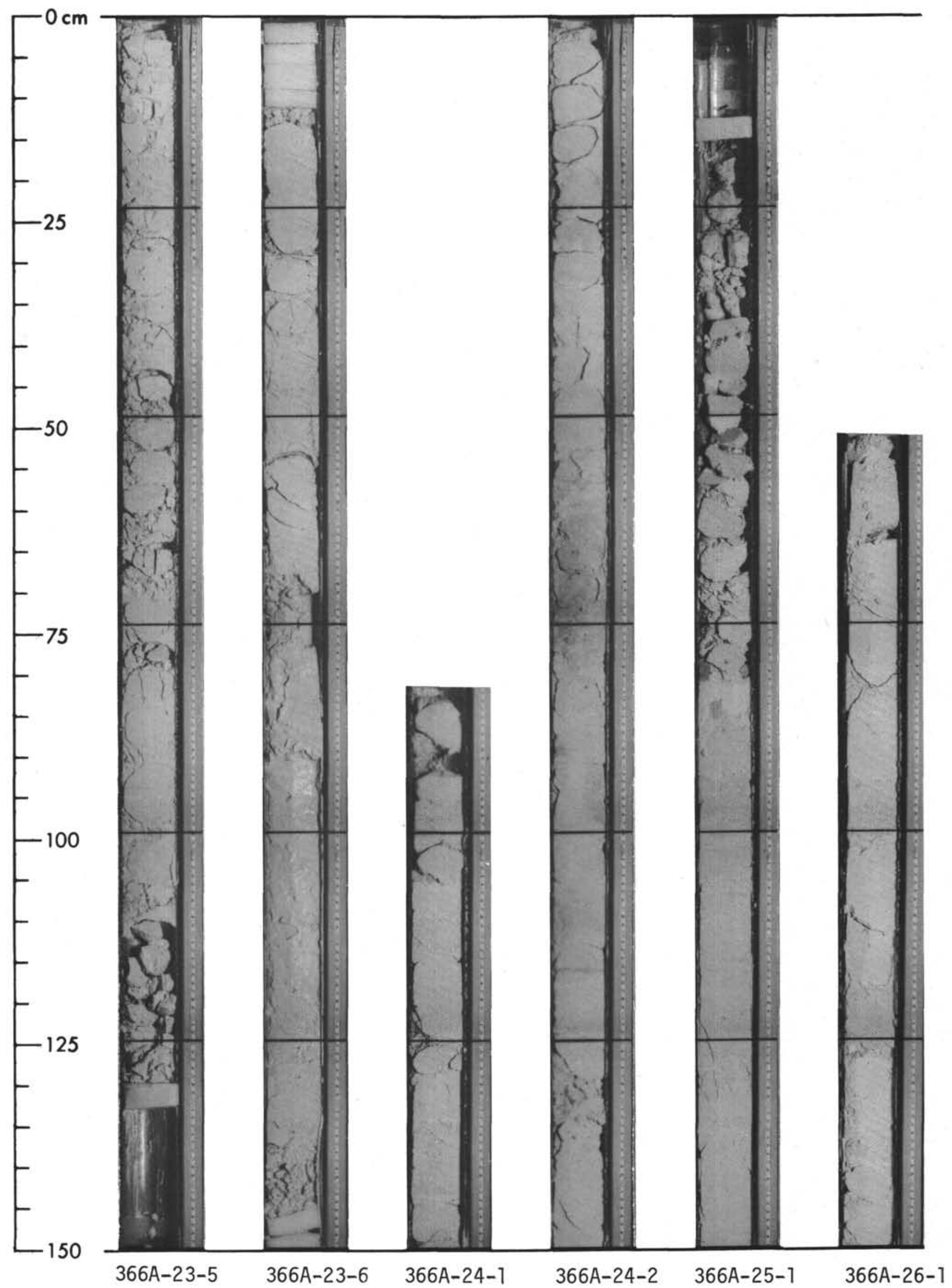




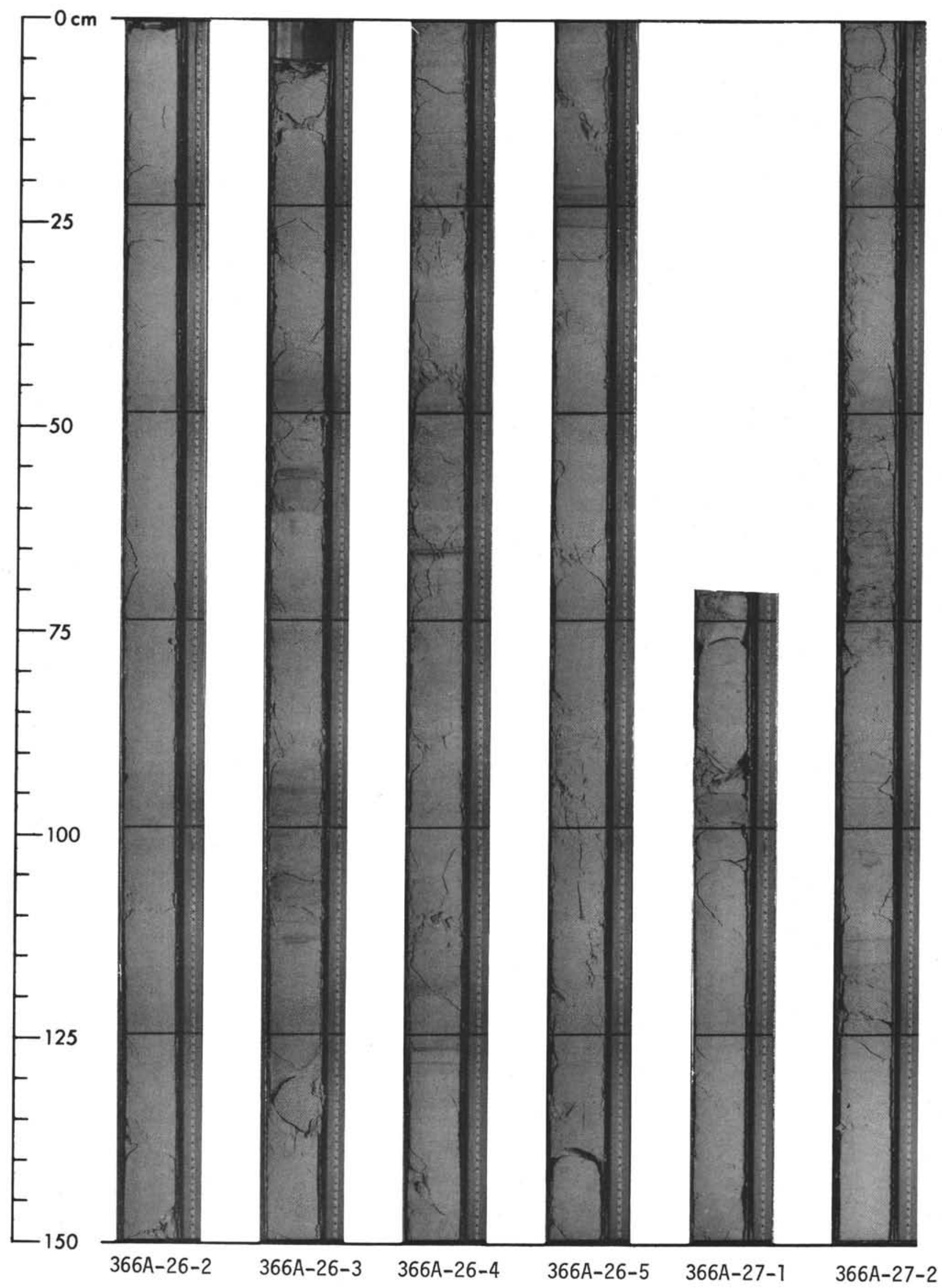




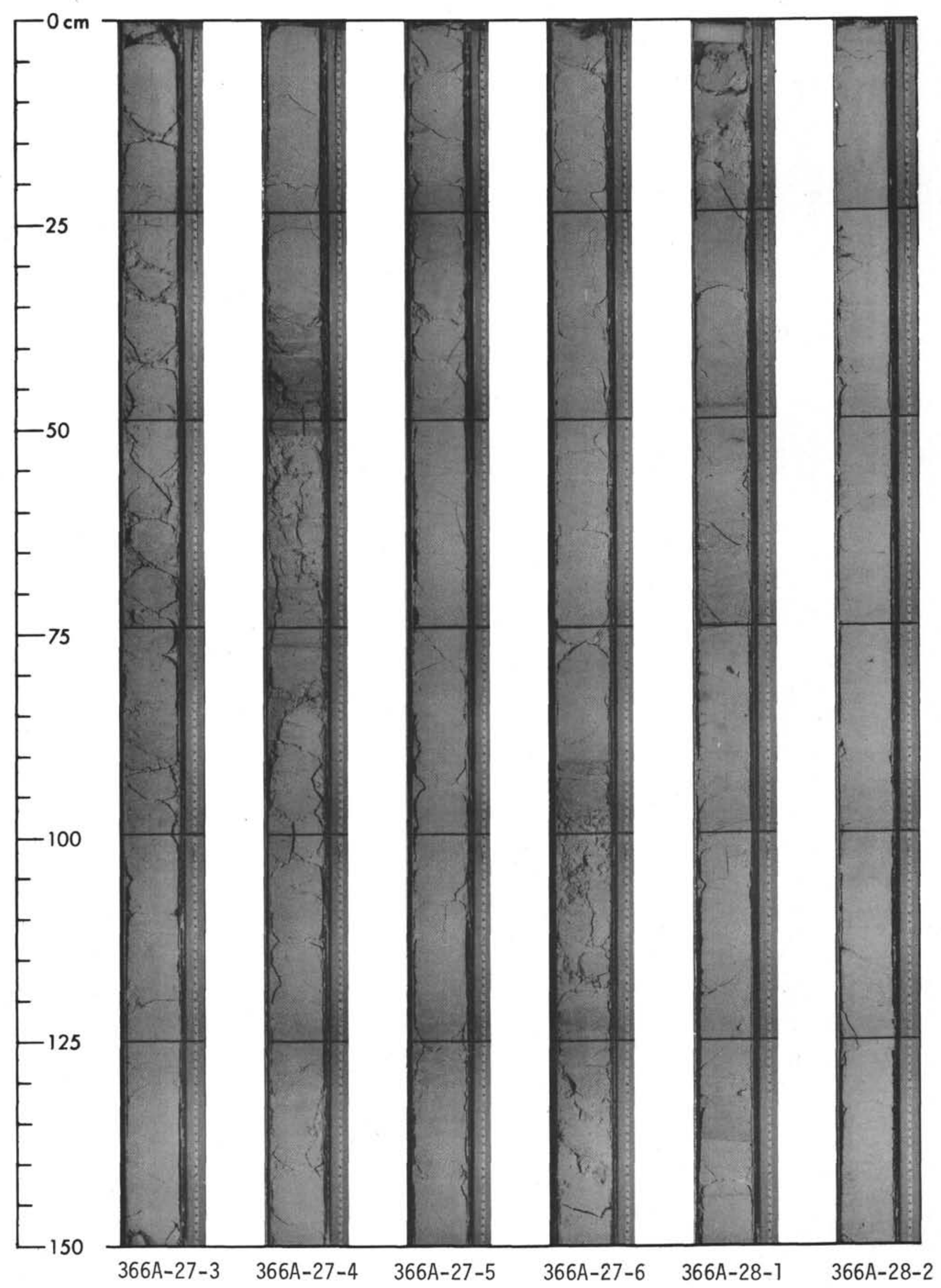




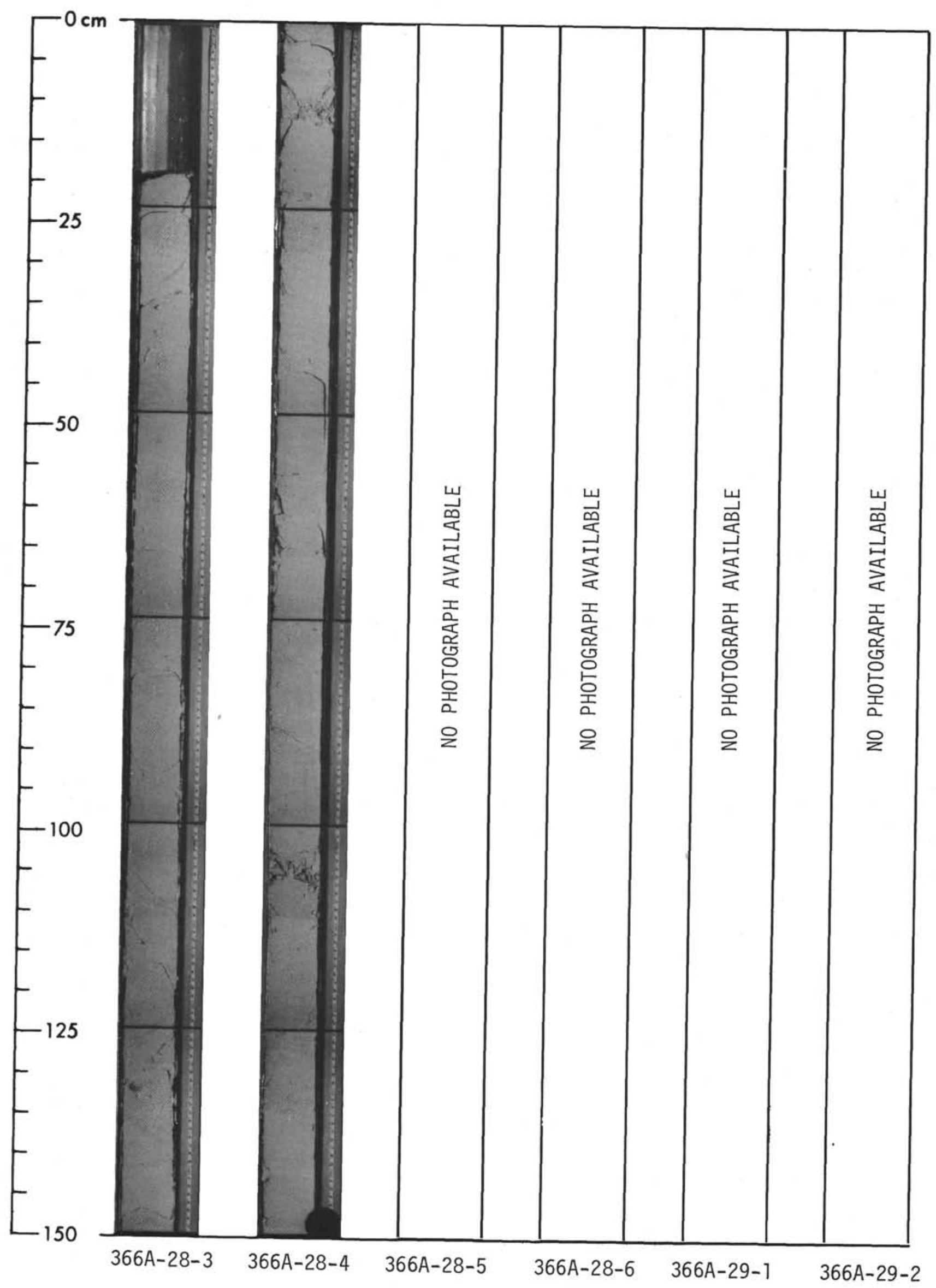




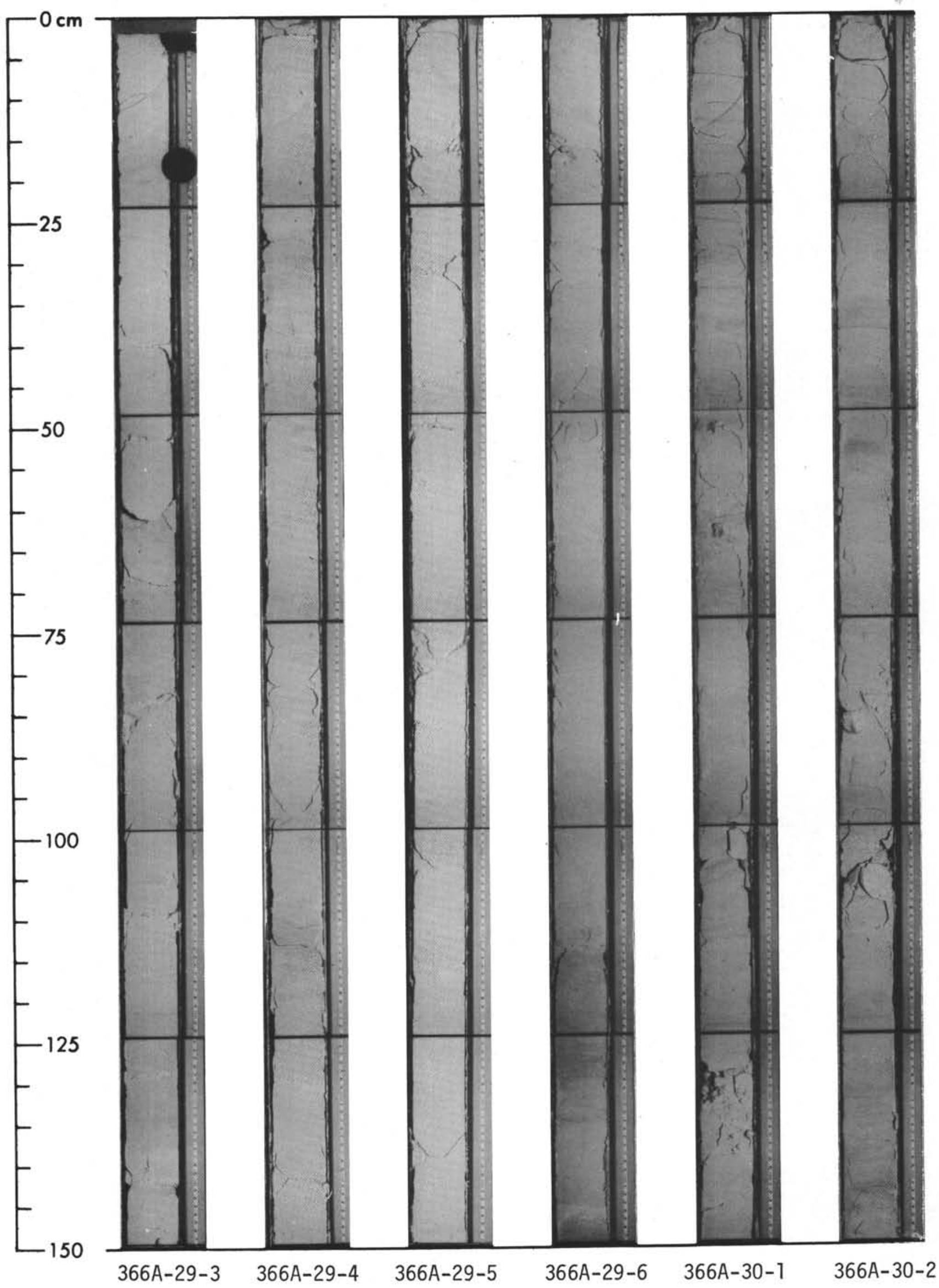


SITE 366: SIERRA LEONE RISE

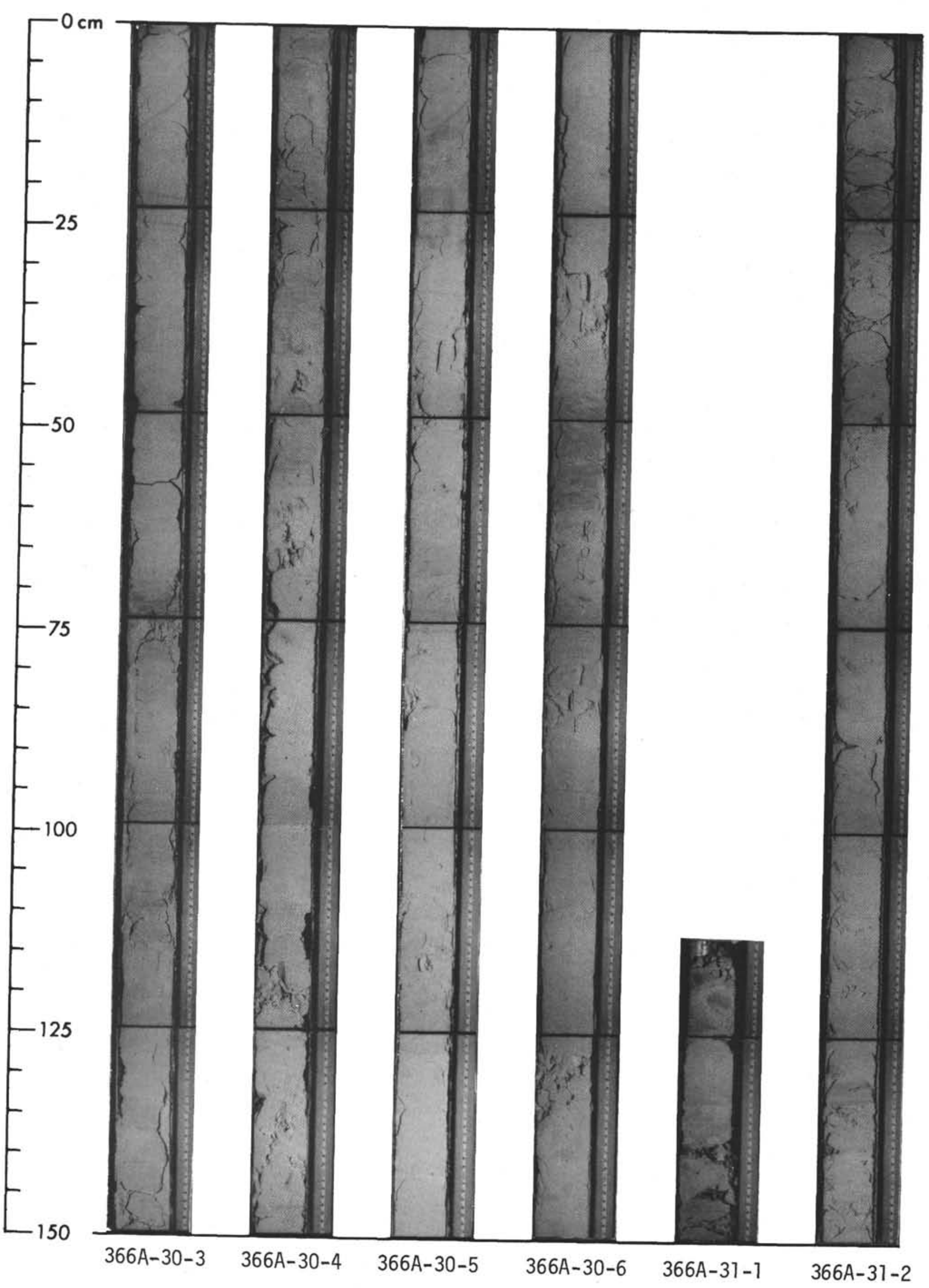




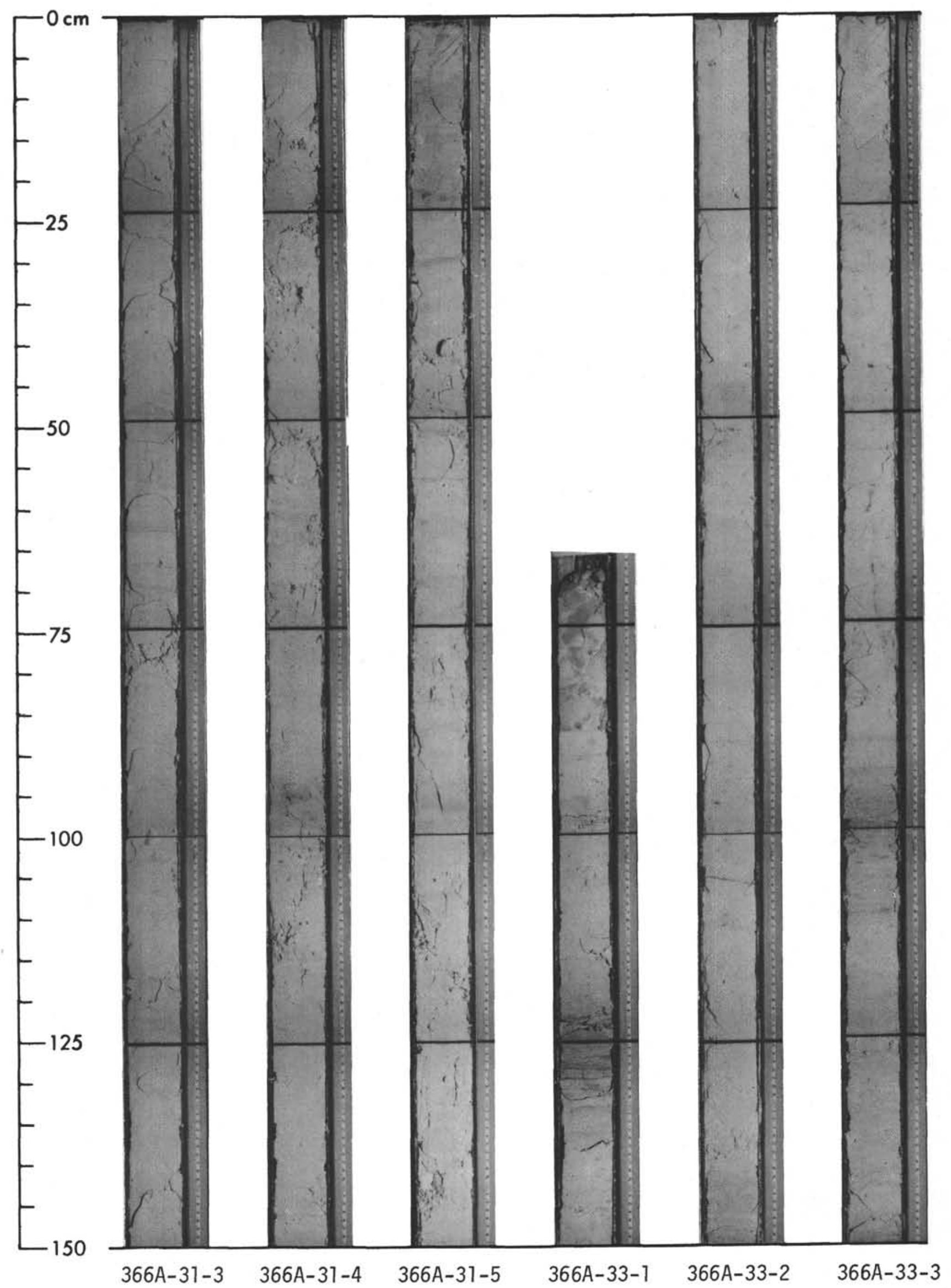




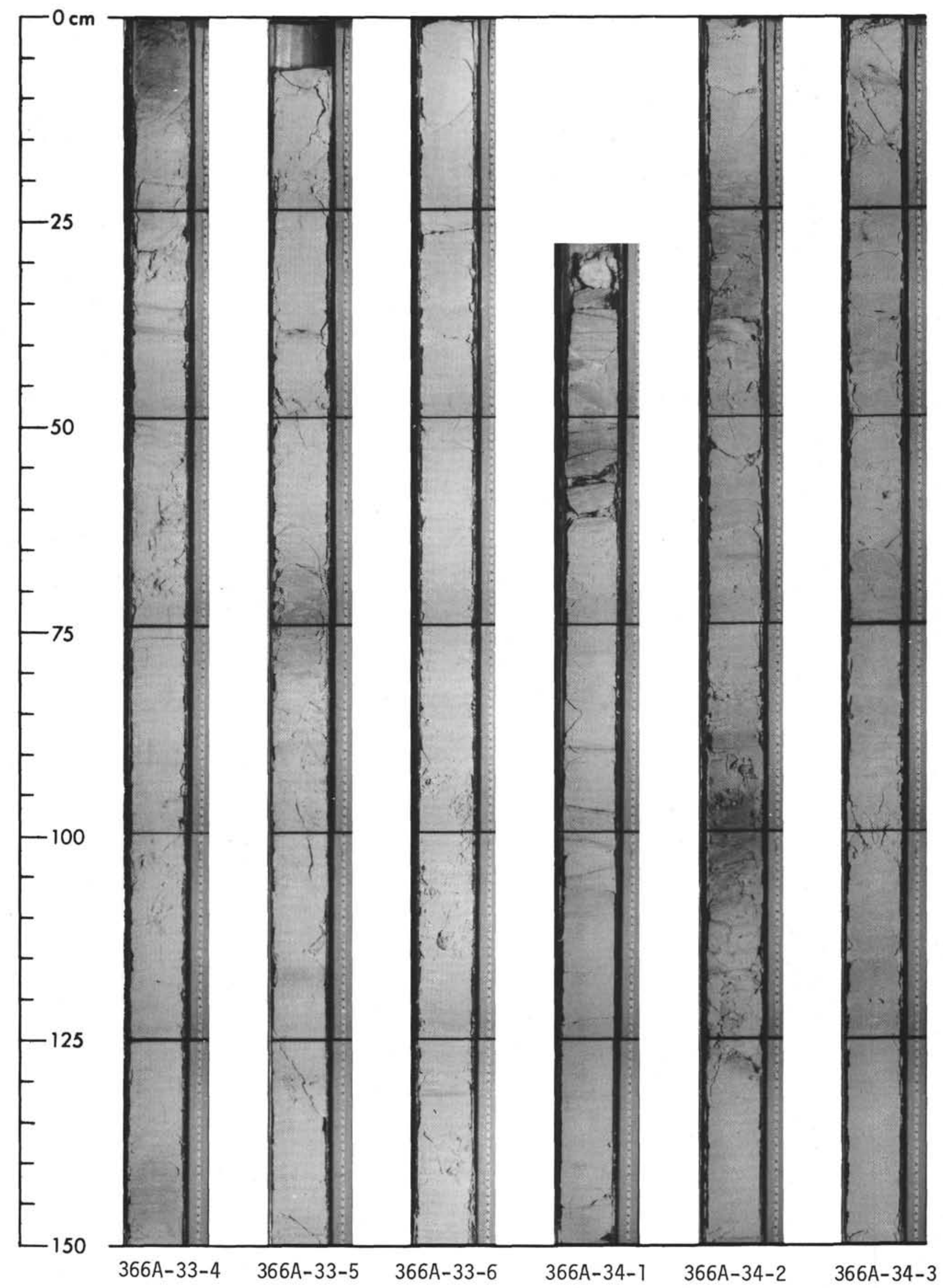




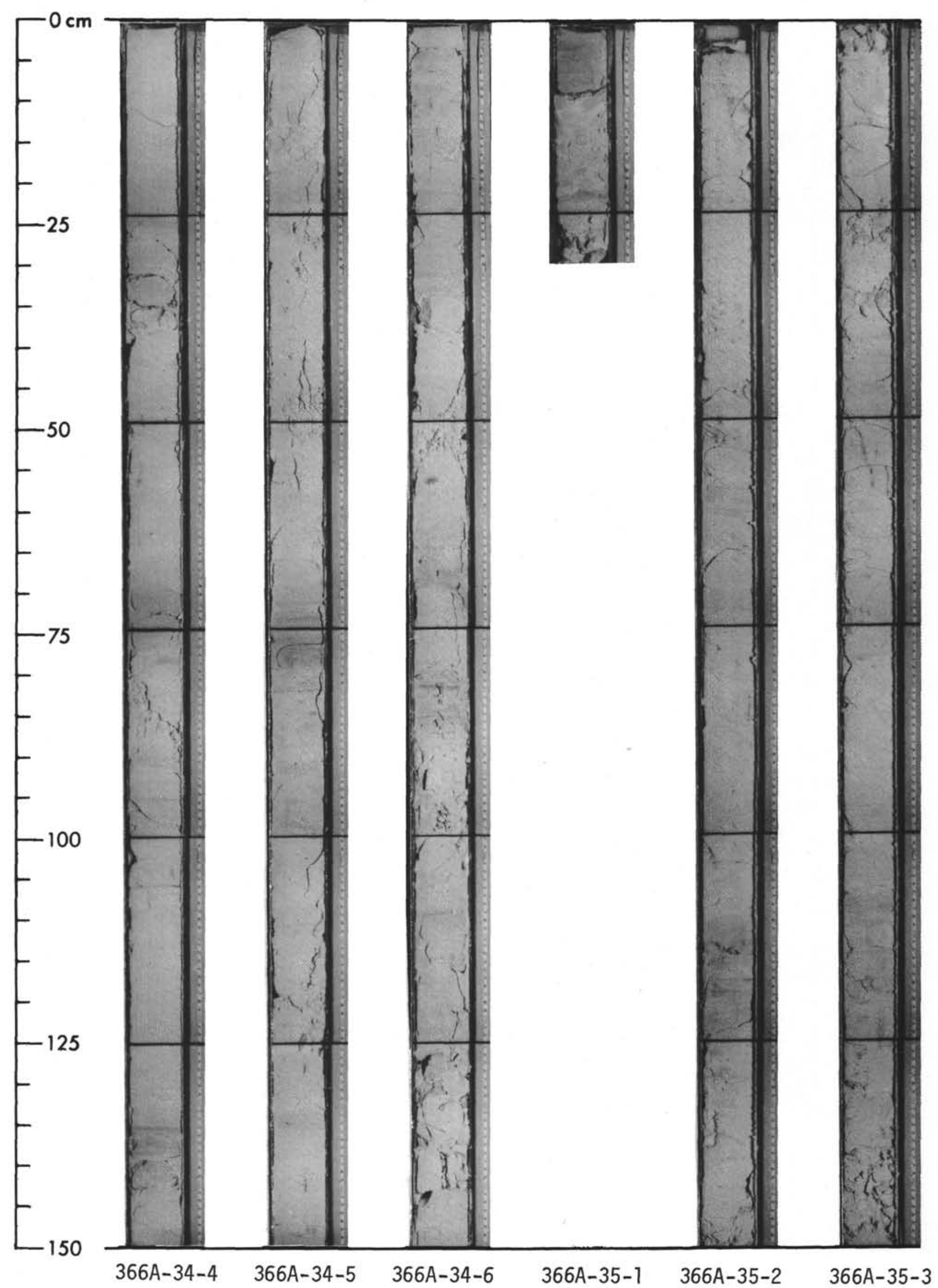




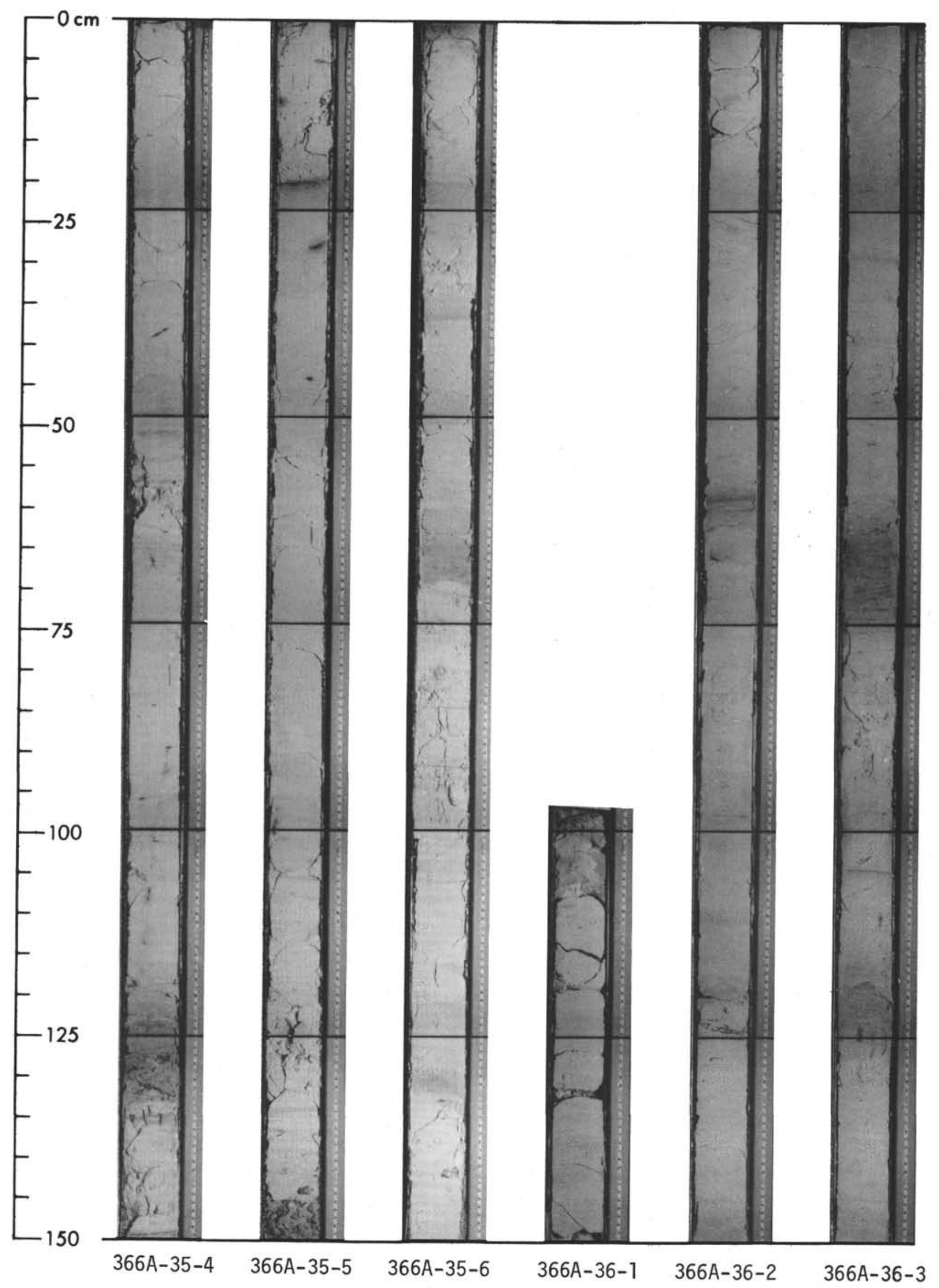




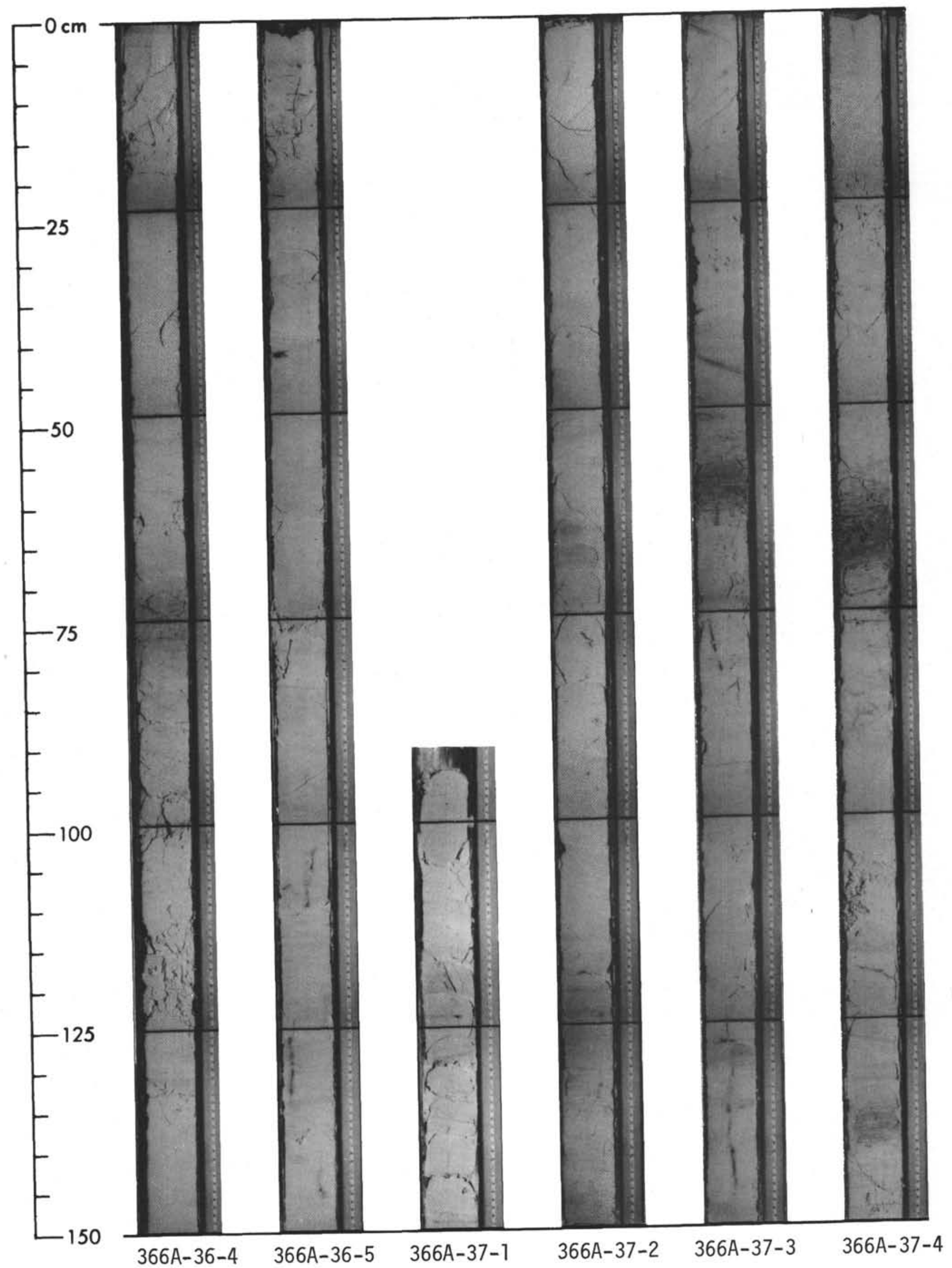


SITE 366: SIERRA LEONE RISE

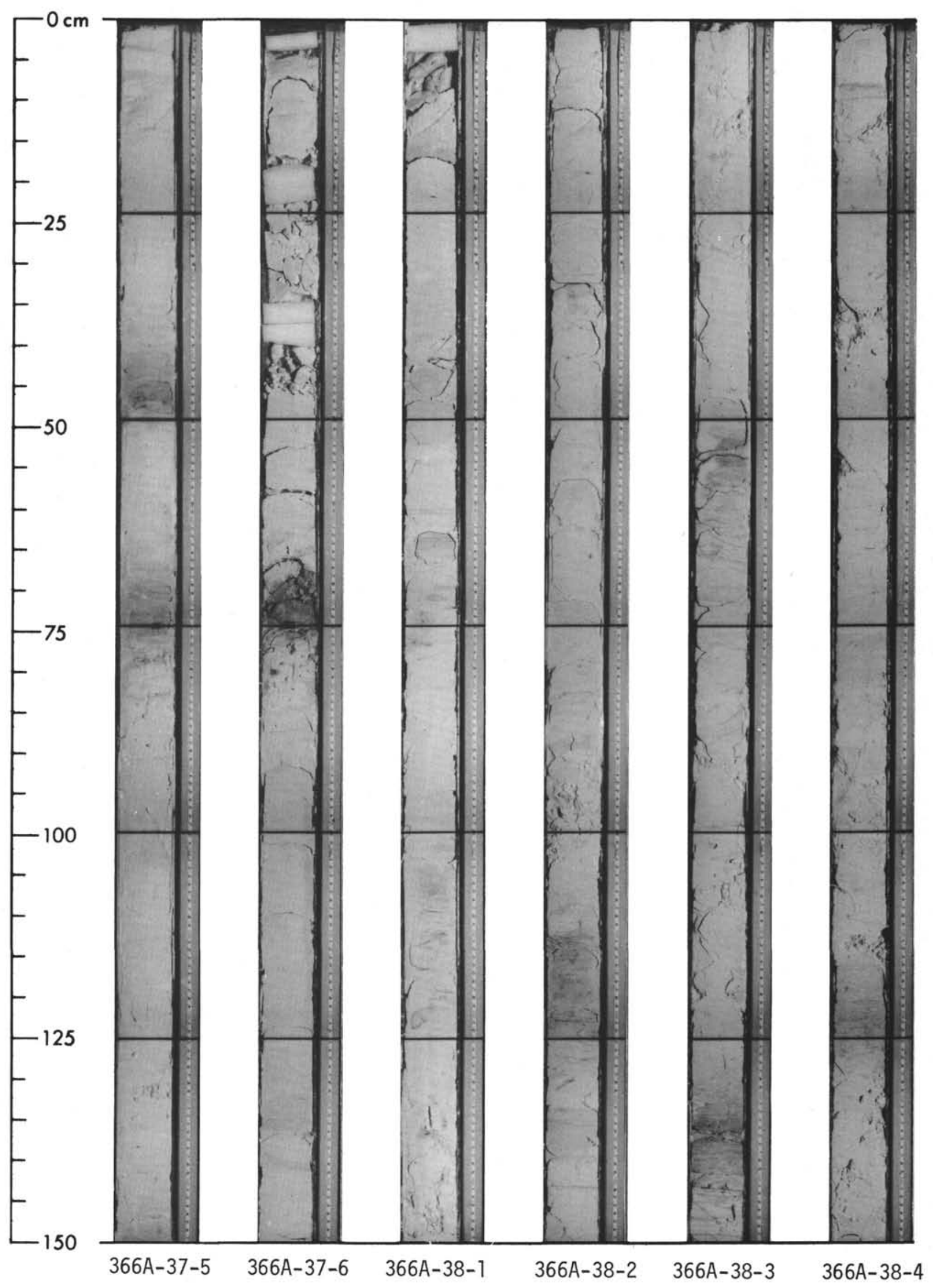




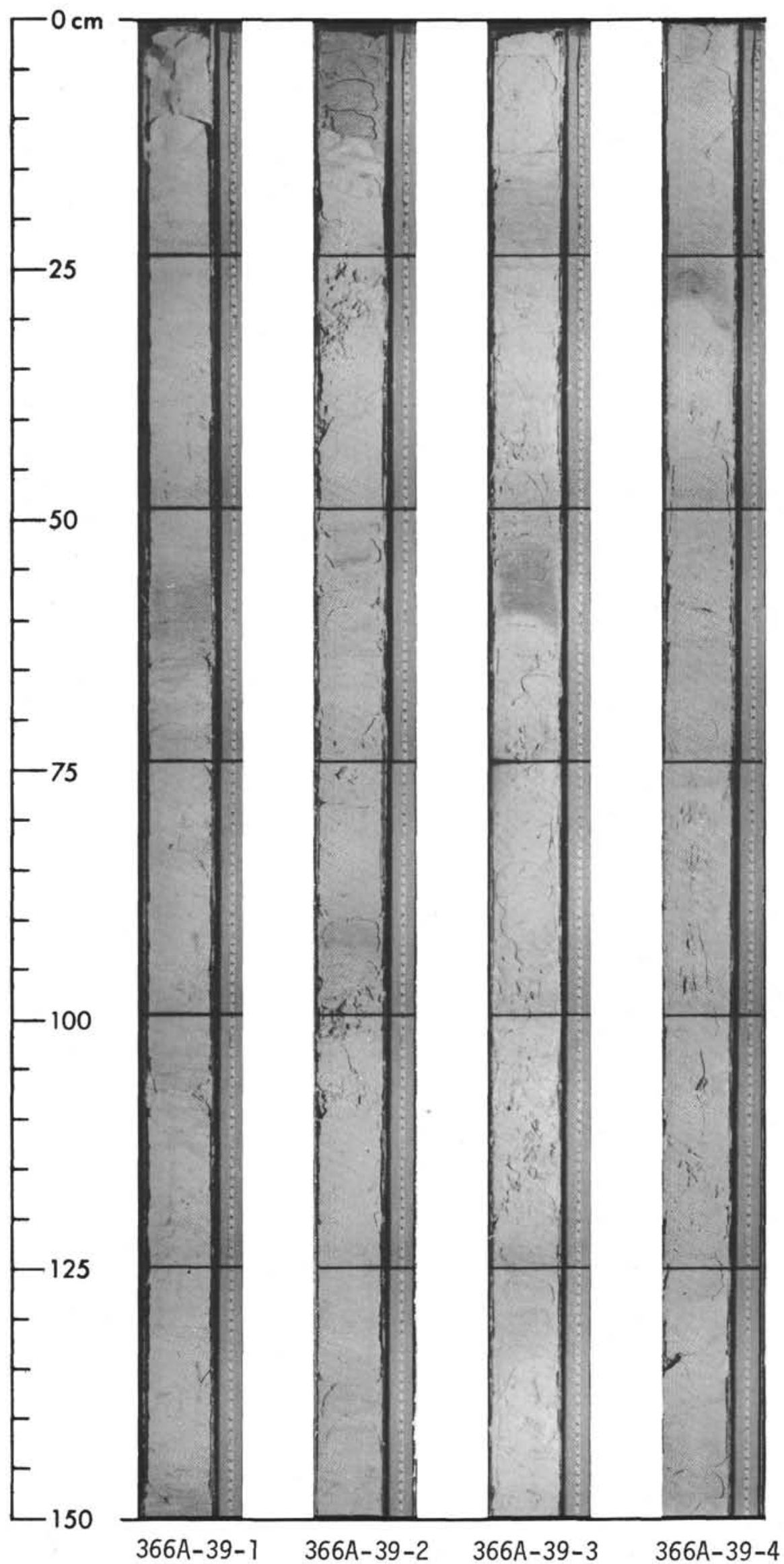

